
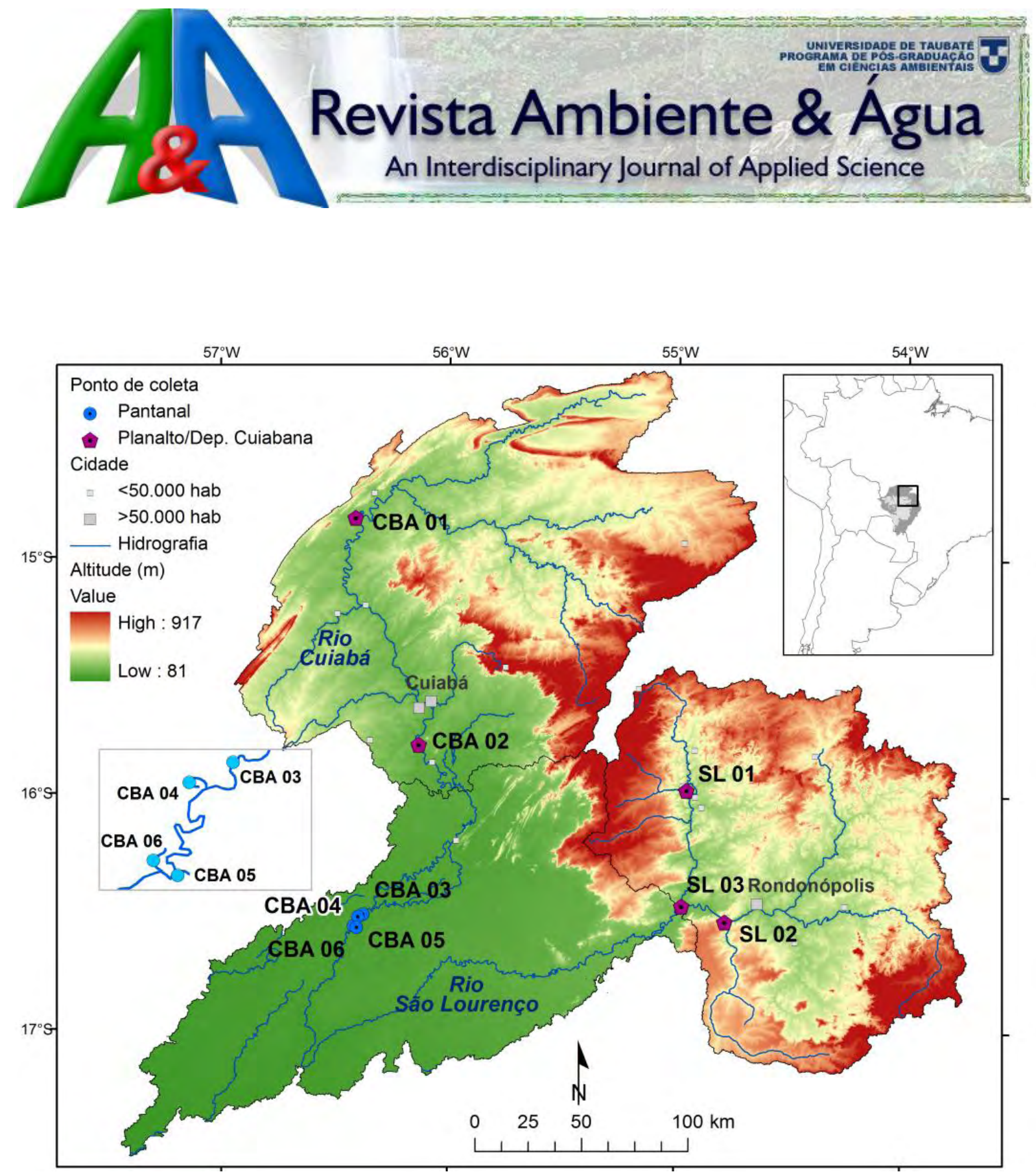

ISSN $=$ 1980-993X (Online $)$

http://www.ambi-agua.net

$24^{\text {th }}$ Edition of Revista Ambiente \& Água - An Interdisciplinary Journal of Applied Science, Taubaté, v. 9, n. 1, p. 1-183, Jan. - Mar. 2014.

(doi:10.4136/ambi-agua.v9.n1) 


\section{EDITORIAL BOARD}

\section{Editor}

\section{Getulio Teixeira Batista}

Institute for Environmental Research in Hydrographic Basins (IPABHi), SP, BR

\section{Associate Editors}

Amaury Paulo de Souza

Antonio Teixeira de Matos

Carlos Eduardo de M. Bicudo

Cláudia S. de C. M. dos S. Cordovil

Delly Oliveira Filho

Ehsan Noroozinejad Farsangi

Gabriel Constantino Blain

Giordano Urbini

Hélio Nobile Diniz

João Vianei Soares

José Carlos Mierzwa

Julio Cesar Pascale Palhares

Luis Antonio Merino

Marcelo dos Santos Targa

Nelson Wellausen Dias

Richarde Marques da Silva

Sergio Francisco de Aquino

Silvio Jorge Coelho Simões

Teresa Maria Reyna

Yosio Edemir Shimabukuro

\author{
Universidade Federal de Viçosa (UFV), BR \\ Universidade Federal de Viçosa (UFV), BR \\ Instituto de Botânica, IBT, BR \\ Centro de estudos de Engenharia Rural (CEER), Lisboa, Portugal \\ Universidade Federal de Viçosa (UFV), BR \\ International Institute of Earthquake Engineering and \\ Seismology(IIEES), Farmanieh, Tehran, Iran \\ Instituto Agronômico de Campinas, IAC, Brasil. \\ University of Insubria, Varese, Italy \\ Inst. Geológico, Sec. do Meio Amb. do Est. de SP (IG/SMA),BR \\ Instituto Nacional de Pesquisas Espaciais (INPE), BR \\ Universidade de São Paulo, USP, BR \\ Embrapa Pecuária Sudeste, CPPSE, São Carlos, SP, BR \\ Institute of Regional Medicine, National University of the Northeast, \\ Corrientes, Argentina \\ Universidade de Taubaté, SP, BR \\ Inst. Bras. de Geogr. e Estatística (IBGE). Aracaju, SE, BR \\ Universidade Federal da Paraíba, UFPB, BR \\ Universidade Federal de Ouro Preto, UFOP, BR \\ Harvard University, US / Univ. Est. Paulista Júlio de Mesquita Filho, \\ UNESP São José, SP, BR \\ Universidad Nacional de Córdoba, Argentina \\ Instituto Nacional de Pesquisas Espaciais (INPE), BR
}

\section{Editorial Section}

Text (EN e ES) Editors

Reference Editor

Layout Editors

Technical Support
Nelson Wellausen Dias, IBGE, BR

Theodore D`Alessio, FL, USA; Getulio T. Batista, UNITAU, BR;

M. Cristina S. Bean, FL, USA

Liliane Castro, Bibliotecária - CRB/8-6748, Taubaté, BR

Vera L. F. Batista, IPABHi \& Getulio T. Batista, UNITAU, BR

Tiago dos Santos Agostinho, LAGEO, UNITAU, BR

Library catalog entry by SIBi - Sistema Integrado de Bibliotecas, UNITAU, SP, BR

Revista Ambiente \& Água - An Interdisciplinary Journal of Applied Science / Instituto de Pesquisas Ambientais em Bacias Hidrográficas. Taubaté. v.9, n. 1 (2006)- Taubaté: IPABHi, 2014

Trimestral

ISSN 1980-993X

1. Ciências ambientais.

2. Recursos hídricos. I. Instituto de Pesquisas Ambientais em Bacias

Hidrográficas

CDD - 333.705

CDU - (03)556.18 


\section{CAPA:}

Planialtimetric map of Cuiabá River basin indicating the points of collection of samples of bottom sediment.

Source: POSSAVATZ, J.; ZEILHOFER, P.; PINTO, A. A.; DORES, E. F. G. C. Resíduos de Pesticidas em Sedimento de fundo de rio na Bacia Hidrográfica do Rio Cuiabá, Mato Grosso, Brasil. Rev. Ambient. Água, Taubaté, vol. 9 n. 1, p. 83-96, 2014. Doi:10.4136/ambi-agua.1263.

\section{EDITORIAL}

A step toward the internationalization of a scientific journal

doi:10.4136/ambi-agua.1342

Getulio Teixeira Batista

\section{ARTIGOS}

Chemical and ecotoxicological assessments of water samples before and after being processed by a Water Treatment Plant

doi:10.4136/ambi-agua.1292

01 Regina Teresa Rosim Monteiro; Gabriela H. Silva; Tamara G. Messias; Sonia C. N. Queiroz; Marcia Regina Assalin; Debora Renata Cassoli; Carlos Henrique Rocha Alves; Antonio Carlos Ferreira; Christian Blaise

Exposure to occupational dust and changes in pulmonary function among cobblestone paving workers of Jimma, Ethiopia

02 doi: $10.4136 /$ ambi-agua.1227

Kalkidan Abate Hassen; Mohammed Sadik Ibrahim

Association between maternal exposure to particulate matter and premature birth doi: 10.4136/ambi-agua.1262

03 Thaiza Agostini Córdoba de Lima; Luiz Fernando Costa Nascimento; Andréa Paula Peneluppi de

Medeiros; Veridiana de Paula Santos

Sweet almond (Prunus amygdalus “dulcis”) seeds as a potential feedstock for Nigerian Biodiesel Automotive Project

04 doi: 10.4136/ambi-agua.1272

Solomon Giwa; Clement Ogunbona

Accumulation and recovery capacity of heavy metals in sand mine ponds of the Otamiri River in Owerri, Nigeria

05 doi: 10.4136/ambi-agua.1226

Dike Henry Ogbuagu; Comfort Barikpoa Samuel

Hidrogeologia e hidroquímica dos aquíferos fraturados associados às rochas vulcânicas ácidas no Município de Carlos Barbosa (RS)

06 doi: 10.4136/ambi-agua.1270

Taison Anderson Bortolin1; Pedro Antonio Roehe Reginato; Marcos Imério Leão; Vania Elisabete

Schneider

Análise fenotípica e genotípica de bactérias heterotróficas e fixadoras de nitrogênio em sedimento na bacia do Rio Cuiabá-MT

07 doi: 10.4136/ambi-agua.1207

Fernanda Viana da Cunha; Selma Baia Batista 
Resíduos de pesticidas em sedimento de fundo de rio na Bacia Hidrográfica do Rio Cuiabá, Mato Grosso, Brasil

Juliana Possavatz; Peter Zeilhofer; Alicio Alves Pinto; André Luiz Tives; Eliana Freire Gaspar de

Carvalho Dores

Acúmulo de nutrientes por forrageiras cultivadas em sistema de escoamento superficial para tratamento de esgoto doméstico

Aline Azevedo Nazário; Giovanni de Oliveira Garcia; Edvaldo Fialho dos Reis; Eduardo de Sá Mendonça; José Guilherme Bergamim Melline

Viabilidade do uso de água residuária tratada na irrigação da cultura do rabanete (Raphanus sativus L.)

Iasmine Louise de Almeida Dantas; Gregorio Guirado Faccioli; Luciana Coêlho Mendonça; Tatiana Pacheco Nunes; Pedro Roberto Almeida Viegas; Larissa Oliveira Gama de Santana

Relação entre vazão e qualidade da água em uma seção de rio doi: 10.4136/ambi-agua.1278

11 Luciano Vieira Barreto; Micael de Souza Fraga; Flávia Mariani Barros; Felizardo Adenilson Rocha; Jhones da Silva Amorim; Stênio Rocha de Carvalho; Paulo Bonomo; Danilo Paulúcio da Silva

Índices de Qualidade da Água e de Estado Trófico na Represa Dr. João Penido (Juiz de Fora, MG)

12 doi: 10.4136/ambi-agua.1290

Magaly H. S. Bucci; Luiz Fernando C. de Oliveira

Análise de BTEX em água: comparação entre duas colunas cromatográficas doi: 10.4136/ambi-agua.1171

13 Danielle de Almeida Carvalho; Rosália Maria de Oliveira; Célia Regina Sousa da Silva; Priscila Tamiasso Martinhon; Sérgio Alves da Silva

Parámetros del modelo de infiltración de Horton obtenidos mediante el uso de un simulador de lluvia - Córdoba, Argentina

14 doi: 10.4136/ambi-agua.1320

Juan Francisco Weber

Análisis jurídico sobre la calidad del servicio del agua en Buenos Aires 


Ambiente \& Água - An Interdisciplinary Journal of Applied Science
ISSN 1980-993X - doi:10.4136/1980-993X
www.ambi-agua.net
E-mail: ambi-agua@agro.unitau.br

\title{
A step toward the internationalization of a scientific journal
}

\author{
doi:10.4136/ambi-agua.1342 \\ Getulio Teixeira Batista \\ Universidade de Taubaté, SP, Brazil \\ Graduate Program in Environmental Sciences \\ Editor-in-Chief of Ambi-Agua Journal \\ e-mail: ambi-agua@agro.unitau.br
}

\begin{abstract}
In this editorial, we discuss simple actions to increase the visibility and impact of the journal based upon strategies to make it better known to the international community and to provide a better return to society. In this $24^{\text {th }}$ issue, we are publishing 15 peer-reviewed papers; 45 additional papers will be published in the remaining three issues of 2014.
\end{abstract}

Keywords: Ambiagua, environment, water resources, social networks.

\section{Um passo em direção à internacionalização de periódicos científicos}

\section{RESUMO}

Neste editorial, ações simples para aumentar a visibilidade e o impacto de uma revista para um público amplo são discutidas com apresentação de estratégias para torná-la mais visível e conhecida e, assim, aumentar o interesse internacional e proporcionar um melhor retorno para a sociedade. Nesta $24{ }^{\text {a }}$ edição, 15 artigos revisados por pares foram publicados e 45 artigos adicionais serão publicados em 2014 nas próximas três edições.

Palavras-chave: Ambiagua, ciências ambientais, recursos hídricos, redes sociais.

\section{DISCUSSION}

This editorial discusses the actions of Revista Ambiente \& Água - An Interdisciplinary Journal of Applied Science to increase its international profile and to achieve recognition for its impact not only scientifically but also socially. Very early on, a decision was made to publish the journal on the Web with all articles freely available to readers in a policy of complete and open online access. Since the launch of the journal, we have all articles with the doi ${ }^{\mathrm{TM}}$ registered with CrossRef, which guarantees permanent access to the articles and greatly facilitates interoperability with many search engines. We give priority to submissions in English, which is the international scientific language. We expect to increase the percentage of articles written in English and soon be publishing mostly in English, which is already the main language of the journal interface.

We continue to practice peer review, with at least two reviewers for each accepted manuscript, and we prioritize previously unpublished papers that make new findings that go beyond descriptive science. In order to be effective at this, we have endeavored to provide the journal to scientists that are active in the journal's thematic area by consulting the $\mathrm{CNPq}$ Lattes and social web platforms such as Academia.edu and ResearchGate. Recently, we have attempted to include the journal in social and academic networks. For example, we have created a Facebook page for the journal (https://www.facebook.com/pages/Revista-Ambiente- 
C381gua/789251397768894), and have all articles registered in Mendeley (http://www.mendeley.com/groups/1682661/ambiente-agua/) with metadata fully inserted. We are currently in the process of inserting the journal in Academia.edu and ResearchGate.

Another important step was to increase the geographic and thematic coverage of the Editorial Committee, which now includes members from Europe, the Middle East and additional countries of Latin America, as can be seen at http://www.ambiagua.net/seer/index.php/ambi-agua/about/editorialTeam. In addition to the Editorial Committee, we have over 600 members in the Ad Hoc Review Panel who are outstanding researchers in the journal's area of scientific focus. Another important measure is to produce the articles in the Extensible Markup Language (XML) format which will facilitate interoperability and portability among systems as it can work in any programming language or operating system and facilitates data queries.

Our main trust now in social networks is motivated by the belief that we have to go beyond the academic world and make research results known to the general public, whose taxes are finally the main funders of research. As a journal of applied science, we expect that the journal's broad dissemination can help to advance technology and thereby foster improvements in the quality of people's lives and in the rational management of resources. Therefore, we hope these initiatives will not only improve the journal's standing in traditional measures of excellence such as the "Journal Citation Report" and "Scopus Journal Analyzer", which are only accessible through subscription, but especially in the SciELO Citation Index and the alternative metrics that are much more comprehensive and freely available on a notfor-profit basis. 


\begin{tabular}{|c}
$\begin{array}{c}\text { Ambiente \& Água - An Interdisciplinary Journal of Applied Science } \\
\text { ISSN 1980-993X - doi:10.4136/1980-993X } \\
\text { www.ambi-agua.net } \\
\text { E-mail: ambi-agua@agro.unitau.br }\end{array}$ \\
\hline
\end{tabular}

\title{
Chemical and ecotoxicological assessments of water samples before and after being processed by a Water Treatment Plant
}

\author{
doi: 10.4136/ambi-agua.1292
}

Received: 28 Jan. 2014; Accepted: 08 Mar. 2014

\author{
Regina Teresa Rosim Monteiro ${ }^{1 *}$; Gabriela H. Silva ${ }^{1}$; Tamara G. Messias ${ }^{1}$; \\ Sonia C. N. Queiroz ${ }^{2}$; Marcia Regina Assalin ${ }^{2}$; Debora Renata Cassoli² \\ Carlos Henrique Rocha Alves ${ }^{1}$; Antonio Carlos Ferreira ${ }^{3}$; Christian Blaise ${ }^{4}$ \\ ${ }^{1}$ Universidade de São Paulo (USP) - Piracicaba, SP, Brasil \\ Centro de Energia Nuclear na Agricultura \\ ${ }^{2}$ Empresa Brasileira de Pesquisa Agropecuária (Embrapa) - Jaguariúna, SP, Brasil \\ Embrapa Meio Ambiente \\ ${ }^{3}$ Serviço Municipal de Água e Esgoto (SEMAE), Piracicaba, SP, Brasil \\ ${ }^{4}$ Centre Saint-Laurent - Montreal, Quebec, Canada \\ Environment Canada \\ *Autor correspondente: e-mail: monteiro@cena.usp.br, \\ gaby_helena@hotmail.com,tamessias@gmail.com,sonia.queiroz@embrapa.br, \\ marcia.assalin@embrapa.br, debora.cassoli@embrapa.br, chra9@hotmail.com, \\ acferreira@semaepiracicaba.sp.gov.br, christian.blaise@ec.gc.ca
}

\begin{abstract}
Physicochemical and ecotoxicological measurements were employed to appraise the water quality of the Corumbataí River raw water (RW) intake, and that of its filtered (FW) and treated (TW) waters, processed by the Water Treatment Plant (WTP) of Piracicaba (SP, Brazil) during 2010. Some herbicides: ametrine, atrazine, simazine and tebuthiuron, were measured, with levels ranging from 0.01 to $10.3 \mu \mathrm{g} \mathrm{L}^{-1}$. These were lower than those required to produce ecotoxicological effects to aquatic life based on published literature. Similarly, trihalomethanes, such as chloroform and bromodichloromethane produced as a result of the WTP process were also shown to be present in concentrations that would neither harm environmental nor human health. Elevated free chlorine concentrations found in FW and TW were credibly responsible for toxicity effects observed in algae and daphnids. (Pseudokirchneriella subcapitata and Daphnia magna). In contrast, results of toxicity testing conducted with Hydra attenuata suggested that this organism is resistant to free chorine and could be used for drinking water evaluations. Coupling bioassays with chemical analyses proved valuable to uncover putative cause-effect relationships existing between physical, chemical and toxic results, as well as in optimizing data interpretation of water quality.
\end{abstract}

Keywords: herbicides residues, trihalomethanes, drinking water.

\section{Avaliações químicas e ecotoxicológicas em amostras de água antes e após serem processadas por uma Estação de Tratamento}

\section{RESUMO}

Avaliações físico-químicas e ecotoxicológicas foram utilizadas para avaliar a qualidade de amostras da água do rio Corumbataí, água bruta (RW), filtrada (FW) e tratada (TW), 
processadas pela Estação de Tratamento de Água (ETA) de Piracicaba (SP, Brasil), em 2010. Alguns resíduos de herbicidas, tais como: ametrina, atrazina, simazina e tebutiuron, foram medidos encontrando níveis entre $0,01-10,3 \mu \mathrm{g} \mathrm{L}^{-1}$ sendo esses menores do que os necessários para produzir efeitos ecotóxicos à vida aquática, com base na literatura publicada. Da mesma forma, trihalometanos, tais como: clorofórmio e bromodiclorometano produzido como resultados do processo da ETA foram também encontrados em concentrações que não prejudicam a saúde ambiental ou humana. Concentrações de cloro livre elevadas foram encontradas nas amostras de água FW e TW e foram os prováveis responsáveis pelos efeitos de toxicidade observados em algas e dáfnias (Pseudokirchneriella subcapitata, Daphnia magna). Por outro lado, resultados dos testes de toxicidade realizados com Hydra attenuata mostraram que este organismo é resistente a água clorado sendo um organismo potencial a ser utilizado para avaliações ecotoxicológicas em águas tratadas. Testes de toxicidade simultâneos com análises químicas revelaram úteis para descobrir relações de causa-efeito existentes entre supostos resultados tóxicos, físicos e químicos e, assim como na melhora de interpretação de dados de qualidade da água.

Palavras-chave: resíduos de herbicidas, trihalometanos, água tratada.

\section{INTRODUCTION}

Water quality is a planetary issue circumscribing both environmental and human health considerations. Adequate physicochemical characteristics of waters coupled with absence of harmful chemical (e.g., metal and organic contaminants) and biological agents (e.g., pathogenic bacteria and parasites) will ensure their good ecological and sanitary status.

Indeed, the type or degree of water treatment for domestic use is strongly dependent on the quality of its source. Classic treatments initially call for gas chlorination of raw water that is efficient in oxidizing harmful substances, followed by calcium addition for $\mathrm{pH}$ adjustment and $\mathrm{Al}(\mathrm{OH})_{3}$ and/or $\mathrm{Fe}(\mathrm{OH})_{3}$ to coagulate colloidal impurities. Water treated in this fashion next goes to lagoons for flocculation, then decantation and filtration. Final water quality is guaranteed with chlorine, fluorine and lime treatment. While chlorine is intended to inactivate or destroy disease-causing organisms that may still be present in water after treatment, lime serves to neutralize excess acidity in order to offset pipe corrosion for water distribution. Addition of fluorine offers protection against tooth decay, as recommended by the World Health Organization (WHO, 2006).

However, water treatment is a double-edged sword that can have both positive and negative consequences. Public health has greatly benefited over time from treatment processes owing to reduction of microbial epidemics in countries applying water sanitation programs (Farland and Gibb, 1993). On the other hand, chlorine addition to water enables reactions with available organic compounds, such as proteins, to form toxic byproducts. The best known products are trihalomethanes (THMs), such as chloroform or trichloromethane $\left(\mathrm{CHCl}_{3}\right)$, bromodichloromethane $\left(\mathrm{CHBrCl}_{2}\right)$ and dibromochloromethane $\left(\mathrm{CHBr}_{2} \mathrm{Cl}\right)$, among others (Paschoalato et al., 2008).

There is unquestionably a risk associated with chemicals used in water treatment. Epidemiological studies have shown positive associations between presence of THMs in drinking water and bladder cancer, and also with recreational activities in water, such as bathing, that lead to greater exposure by inhalation and dermal absorption, all of which incur higher risks than that posed by preparation and consumption of food (Villanueva et al., 2007). A connection between the presence of THMs in tap water supplied to the metropolitan region of São Paulo and aspects of low weight in newborns has been found, as well as congenital malformation and prematurity (Santos and Gouvea, 2011). TMHs are clearly a concern for public health in Brazil, and a maximum allowed concentration of $0.1 \mathrm{mg} \mathrm{L}^{-1}$ has been set for 
drinking water (Brasil, 2011). Because THMs are just some of the byproducts that can be formed by chlorination, their presence can signal that of other potentially hazardous chemicals (Silva et al., 2013). Therefore, control of THMs in water supplies could help reduce the levels of other compounds originating from chlorination (WHO, 1966).

Pesticides comprise another class of pollutants widely found in surface and underground water bodies worldwide, due to their widespread use in agricultural and urban areas (Schäfer et al., 2011). The presence of herbicides, in particular, has been observed in the Corumbataí River (Armas et al., 2005; Monteiro et al., 2008), the aqueous source processed by the water treatment plant (WTP) of this investigation.

Our study sought to assess the quality of water processed by the Water Treatment Plant (WTP) of Piracicaba (SP, Brazil), the source of which is the Corumbataí River. After treatment, drinking water is distributed to populations living in the municipality of Piracicaba (SP, Brazil). To optimize the scope of our investigation, we made use of a combined chemical-biological strategy incorporating physicochemical $\left(\mathrm{O}_{2}, \mathrm{pH}\right.$, conductivity, $\mathrm{T}{ }^{\circ} \mathrm{C}$, free chlorine) and chemical analysis (THMs, herbicides), as well as effects measurements by selected ecotoxicological tests representative of diverse aquatic life (algae and microinvertebrates). Within this approach, a secondary objective sought to appreciate the usefulness of bioassays in complementing chemical analysis in interpreting water quality.

\section{MATERIAL AND METHODS}

\subsection{Sampling}

Water samples were collected at different sites (Figure 1) in March, May, July, October and December of 2010. Samples were collected at sampling stations with a grab sampler and placed in three different $1 \mathrm{~L}$ polypropylene bottles $(1 \mathrm{~L}$ for physicochemical analysis, $1 \mathrm{~L}$ for contaminant analysis and $1 \mathrm{~L}$ for bioassays) and kept at $4^{\circ} \mathrm{C}$ in a cooler containing icepacks for immediate transport to the laboratory. Upon arrival, samples for contaminant analysis were frozen at $-18^{\circ} \mathrm{C}$.

Production of drinking water by the WTP from treated Corumbataí River water is illustrated in Figure 1. Briefly, raw river water intake is first subjected to gas chlorination to promote oxidation of potentially hazardous compounds, and afterwards receives calcium $\left(\mathrm{Ca}(\mathrm{OH})_{2}\right)$ addition for $\mathrm{pH}$ adjustment and $\mathrm{PAC}-\mathrm{Al}(\mathrm{OH})_{3}$ to coagulate colloidal impurities. Flocculation, decantation and sand/charcoal filtration of water then occur in lagoons. Lastly, $\mathrm{pH}$-neutralizing lime addition to prevent pipe corrosion during water distribution, as well as chlorination and fluorination to ensure and enhance water quality, essentially terminate the WTP drinking water production process.

\subsection{Rainfall data collection}

The cumulative rainfall of each month and cumulative five days before collecting water samples (Table 1) were provided by the pluviometric database of the automated Meteorological Station of Piracicaba (USP, 2011).

\subsection{Chemical analysis}

\subsubsection{Physicochemical determinations}

Temperature, $\mathrm{pH}$, conductivity and dissolved oxygen were measured using the equipment's Digimed DM2 ${ }^{\circledR}$ and $\mathrm{CD} 21^{\circledR}$ (Digimed, São Paulo, SP, Brasil), according to manufacturer's instructions. Free chlorine was measured by titration (APHA et al., 2005). 


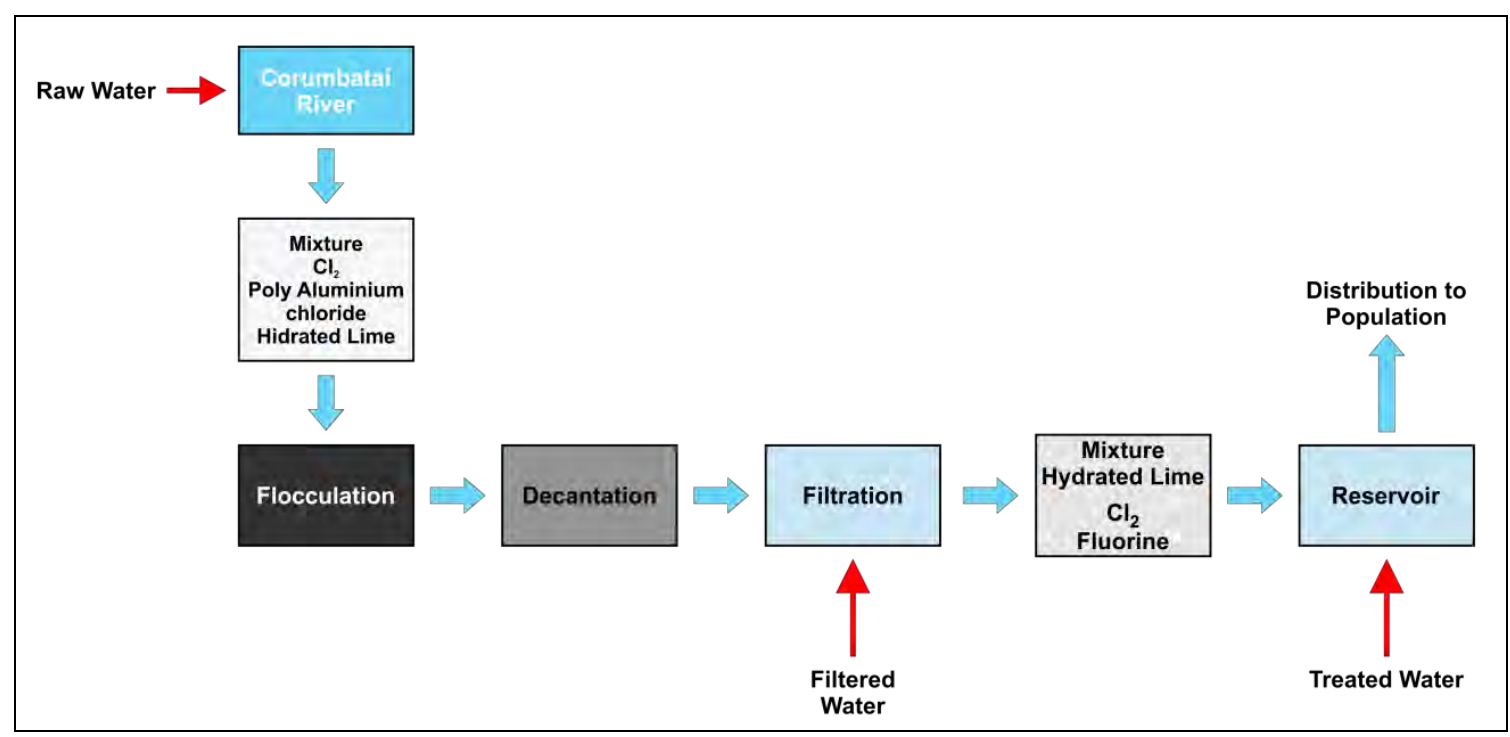

Figura 1. Water Treatment Plant (WTP) process and sampling stations.

Table 1. Cumulative rainfall data of the month and five days before collecting water.

\begin{tabular}{c|cc}
\hline Sampling period (2010) & $\begin{array}{c}\text { Rainfall month } \\
(\mathrm{mm})\end{array}$ & $\begin{array}{c}\text { Rainfall 5 days } \\
(\mathrm{mm})\end{array}$ \\
\hline March & 98.4 & 0.0 \\
May & 24.4 & 4.9 \\
July & 62.1 & 0.0 \\
October & 87.4 & 28.2 \\
December & 243.8 & 40.2 \\
\hline
\end{tabular}

\subsubsection{Trihalomethanes}

Chloroform, bromodichloromethane, dibromochloromethane and bromoform, 2000 $\mu \mathrm{g} \mathrm{mL}^{-1}$, were purchased from Supelco, (Bellefonte, PA, USA). The method was adapted from Serrano and Gallego (2007) and Cuela et al. (2006). A Quattro Micro Waters Gas Chromatography $^{\circledR}$ (Waters, Milford, MA, USA) coupled to mass spectrometer (CG-MS/MS) apparatus was used; which included a CTC Analytics autosampler (CombiPal). The capillary column used was DB-5 MS $30 \times 0.25 \mathrm{~mm}$ X $0.25 \mu \mathrm{m}$ with a constant flow of $1.0 \mathrm{~mL} \mathrm{~min}{ }^{-1}$. Chromatographic conditions were as follows: oven temperature $31^{\circ} \mathrm{C}(1 \mathrm{~min})$, increased $1^{\circ} \mathrm{C} \mathrm{m^{-1 }}$ until $33^{\circ} \mathrm{C}(2 \mathrm{~min})$ and up to $200^{\circ} \mathrm{C}$ at $100^{\circ} \mathrm{C} \min ^{-1}(3 \mathrm{~min})$; inlet mode, splitless operation with and temperature at $200^{\circ} \mathrm{C}$. Electron ionization $(70 \mathrm{eV})$ was applied in the SIR mode, the following ions were used: $\mathrm{m} / \mathrm{z}$ 47, 83, 85 for Chloroform; m/z. 83, 85, 129 for dichlorobromomethane; $\mathrm{m} / \mathrm{z}$ 83, 85, 129 for dibromochloromethane; and m/z 171, 173, 175 for bromoform. The transferline temperature was $250^{\circ} \mathrm{C}$ and source temperature at $150^{\circ} \mathrm{C}$. Headspace (HS) method: for the HS procedure, $12 \mathrm{~mL}$ of each water sample, mixed with $3 \mathrm{~g}$ of $\mathrm{KCl}$, were added to glass tubes. The tubes were sealed with rubber caps, the content mixed, and placed in an oven at $80^{\circ} \mathrm{C}$ for 20 min to permit the $\mathrm{HS}$ to reach equilibrium. A gas aliquot of $1 \mathrm{~mL}$ was withdrawn through the rubber cap with a gas-tight syringe and injected into the gas chromatograph. The syringe was maintained at $90^{\circ} \mathrm{C}$ in order to prevent internal condensation on the walls. The linearity was in the range $0.05-1.50 \mu \mathrm{g} \mathrm{mL}^{-1}$.

\subsubsection{Herbicides}

The choice for the water sample from October was due after long heavy rain following a prolonged drought. A $250 \mathrm{~mL}$ volume of water sample was percolated through the SPE 
cartridges (Oasis HLB, Waters) under vacuum at a flow-rate of $5 \mathrm{~mL} \mathrm{~min}^{-1}$. Before sample application, the SPE cartridges were conditioned with $1 \mathrm{~mL}$ of methanol and equilibrated with $1 \mathrm{~mL}$ of water $\mathrm{pH} 2.0$. After the sample had passed through the cartridge by vacuum, the cartridge was washed with methanol:water $(5: 95, \mathrm{v} / \mathrm{v})$ and dried under vacuum for $5 \mathrm{~min}$. The analytes were then eluted with $2 \mathrm{~mL}$ of methanol and submitted to the LC-MS/MS analysis.

The chromatographic separations were carried out on a Varian $1200 \mathrm{~L}$ triple quadrupole MS/MS using a Polaris $3 \mathrm{C} 18 \mathrm{~A}$ column (150 mm X $2.0 \mathrm{~mm}$ i.d., $5 \mu \mathrm{m}$ particle size). The mobile phase consisted of deionized water with ammonium acetate $10 \mathrm{mM} \mathrm{L}^{-1}$ : Methanol 25:75 (v/v). The mobile phases were filtered daily using $0.22 \mu \mathrm{m}$ filters. The flow rate was $0.20 \mathrm{~mL} \mathrm{~min}^{-1}$ and the total run time of $18 \mathrm{~min}$. The mass spectrometer with an electrospray ionization source working in positive and negative ionization mode was used. The optimal for ionization of the analytes were source temperature, $50^{\circ} \mathrm{C}$; pressure and temperature of desolvation gas $\left(\mathrm{N}_{2}\right) 28$ psi and $280^{\circ} \mathrm{C}$, respectively. Argon was used as the collision gas. Acquisition was performed in multiple-reaction monitoring (MRM) mode. Electrospray ionization working parameters (ionization mode, precursor and product ions, cone voltage and collision energy) were optimized using infusion of individual standards solutions of the compounds $\left(1 \mu \mathrm{g} \mathrm{mL}^{-1}\right)$ at $20 \mu \mathrm{L} \mathrm{min}$. The MRM transitions monitored were Ametryn $(228>186$ and $228>96)$ Atrazine $(216>174$ and 216>95.9) Simazine (202.0>124.0 and 202.0>95.9) Picloram $(239.9>124.9$ and $239.9>158.9)$ and Tebuthiuron $(228.0>172.0$ and $228.0>115.9)$. The validation procedure was conducted to determine, selectivity, linearity, recovery of the pesticides, limit of quantification (LOQ), accuracy, and precision (repeatability and intermediate precision). The response of detector was linear for all herbicides studied the range $0.005-0.050 \mu \mathrm{g} \mathrm{mL}^{-1}$ with correlations coefficients $>0.99$. The quantification limit of this method was $0.008 \mu \mathrm{g} \mathrm{L}^{-1}$ for Ametryn, Atrazine and Tebuthiuron. For others herbicides the quantification limit was $0.08 \mu \mathrm{g} \mathrm{L}^{-1}$. The validated method showed good recuperation for all pesticides between $70-120 \%$.

\subsection{Toxicity tests and statistical analyses.}

Four well-standardized bioassays representing three trophic levels were employed to assess the toxic potential of all water samples. Test organisms comprised Hydra attenuatea (Blaise and Kusui, 1997), Daphnia magna (Environment Canada, 1996) and Pseudokirchneriella subcaptata (Blaise et al., 2000), as, secondary and primary consumer and producer, respectively. The methodological procedures are described in Santos et al. (2007).

Correlation analysis was also performed on physicochemical data parameters, as well as on toxicity test endpoint results, and combinations thereof, using the Pearson-moment method to seek out trends among the various measurements compared. All statistical tests were performed using the Statistic software package (version 5.5). Based on results obtained, Redundancy Analysis (RDA) correlations based on Canoco software, as described by Hair et al. (1995), were also conducted on toxicity responses of algae and hydra to trihalomethanes and herbicides concentrations for the October 2010 data.

\section{RESULTS AND DISCUSSION}

\subsection{Physicochemical data}

The physicochemical characteristics of water intake from the Corumbataí River (RW samples) and its treatment by the WTP process (FW and TW samples) are reported in Table 2. Overall, RW sample parameters suggest that water taken up from this river appears adequate to undergo treatment for drinking water purposes. Indeed, dissolved oxygen (D.O.) levels display a normal range of variation from March to October (6.7 to $9.3 \mathrm{mg} \mathrm{L}^{-1}$ ). Only in December is a low value of $3.9 \mathrm{mg} \mathrm{L}^{-1}$ of dissolved oxygen observed for RW. This can likely 
be explained by substantially higher rainfall in December (see Table 1) that will increase organic loading to the river with subsequent trigger of increased microbial activity and oxygen consumption. Correlation analysis between rainfall (Table 1) and D.O. data (Table 2) tend to confirm this hypothesis as a significant negative relationship was observed between these two parameters $(\mathrm{R}=-0.93 ; p<0.05)$. Corumbataí River $\mathrm{RW}$ conductivity is also influenced by rainfall $(\mathrm{R}=-0.95 ; p<0.05)$, as the latter dilutes the former when precipitation increases [e.g., substantial rainfall in December 2010 of $243.8 \mathrm{~mm}$ (Table 1) decreases conductivity to a low of $130.8 \mu \mathrm{E} \mathrm{cm}^{-1}$ (Table 2)]. In contrast to RW, FW as well as TW of the Corumbataí River demonstrate slight increase in $\mathrm{pH}$ and conductivity, as well as the presence of free chlorine (highest levels observed in TW), owing to WTP processes. The importance of each physical and chemical parameter measured is parsed and presented by Araújo and Oliveira (2013).

Table 2. Physicochemical characteristics of water samples from March to December 2010.

\begin{tabular}{l|cccccc}
\hline \multirow{3}{*}{ Period (2010) } & Sample type & $\begin{array}{c}\text { Dissolved } \\
\text { oxygen } \\
\left(\mathrm{mg} \mathrm{L}^{-1}\right)\end{array}$ & pH & $\begin{array}{c}\text { Conductivity } \\
\left(\mu \mathrm{S} \mathrm{cm}^{-1}\right)\end{array}$ & $\begin{array}{c}\text { Temperature } \\
\left({ }^{\circ} \mathrm{C}\right)\end{array}$ & $\begin{array}{c}\text { Free } \\
\text { Chlorine } \\
\left(\mathrm{mg} \mathrm{L}^{-1}\right)\end{array}$ \\
\hline \multirow{3}{*}{ March } & RW & 6.72 & 7.15 & 144.7 & 22.7 & 0.00 \\
& FW & 7.13 & 7.40 & 181.7 & 22.8 & 1.75 \\
& TW & 6.77 & 8.53 & 255.0 & 22.5 & 2.50 \\
\hline \multirow{3}{*}{ May } & RW & 8.14 & 6.70 & 165.0 & 22.3 & 0.00 \\
& FW & 7.24 & 7.96 & 215 & 22.3 & 0.35 \\
& TW & 7.32 & 8.20 & 231 & 22.5 & 2.50 \\
\hline \multirow{3}{*}{ October } & RW & 9.26 & 6.86 & 151.3 & 24.5 & 0.00 \\
& FW & 9.98 & 7.12 & 166.5 & 24.1 & 1.10 \\
& TW & 10.21 & 8.23 & 194.0 & 24.7 & 2.80 \\
\hline \multirow{3}{*}{ December } & RW & 7.43 & 7.30 & 149.3 & 23.4 & 0.00 \\
& FW & 7.78 & 7.90 & 211.0 & 23.6 & 0.34 \\
& TW & 8.12 & 8.34 & 223.8 & 24.7 & 2.10 \\
\hline & FW & 3.90 & 5.80 & 130.8 & 24.9 & 0.00 \\
& FW & 5.17 & 7.50 & 199.7 & 25.1 & 0.20 \\
\hline
\end{tabular}

Abbreviations: raw water (RW), filtered water (FW) and treated water (TW).

\subsection{Trihalomethanes and herbicide data}

Chemical analysis of some trihalomethanes (THMs) commonly formed during drinking water treatments (Paschoalato et al., 2008), and of herbicides whose presence has already been reported for the Corumbataí River (Armas et al., 2005; Monteiro et al., 2008), was undertaken following the October 2010 sampling of RW, FW and TW (Table 3). In the method used, the limit of detection was obtained for THMs studied were: $1 \mu \mathrm{g} \mathrm{L}^{-1}$ for chloroform and dichlorobromomethane; $2 \mu \mathrm{g} \mathrm{\textrm {L } ^ { - 1 }}$ for dibromochloromethane and $5 \mu \mathrm{g} \mathrm{L}^{-1}$ for bromoform. At a signal/noise of 10/1 the limit of quantification was $5 \mu \mathrm{g} \mathrm{L^{-1 }}$ for chloroform, dichlorobromomethane, dibromochloromethane and $25 \mu \mathrm{g} \mathrm{L}^{-1}$ for bromoform. While THMs 
were absent in RW, chloroform and bromodichloromethane were observed in both FW and TW, likely formed as a result of the WTP process. Their concentrations in TW destined for human consumption are, however, below the maximum acceptable concentration of $0.1 \mathrm{mg} \mathrm{L}^{1}$ set for drinking water in Brazil (Brasil, 2011).

Of the five herbicides analyzed following water sample collection in October 2010, only atrazine and simazina were found in RW, FW and/or TW samples. Ametryn was found in the RW sample. The results are shown in Table 3. Even though all samples were taken on the same day in October, FW and TW samples are representative of water that has already been in the WTP process for two days and they are therefore two days older than RW samples. This offers an explanation for the fluctuations in herbicide concentrations observed between RW and FW/TW samples. The herbicides atrazine and simazine were present in concentrations that surpass those considered acceptable for human consumption of $2 \mu \mathrm{g} \mathrm{L}^{-1}$ according to Brazilian regulations (Brazil, 2011). Furthermore, it is known that atrazine is not removed by WTPs (Benotti et al., 2009; Quintana et al., 2001). The potential ecotoxic effects of THM and herbicide concentrations found in RW, FW and TW are discussed along with the bioanalytical data presented below.

Table 3. Trihalomethane and herbicide residues $\left(\mu \mathrm{g} \mathrm{L}^{-1}\right)$ in water samples of the Corumbataí River collected in October 2010 at the WTP.

\begin{tabular}{l|ccc}
\hline Trihalomethanes & $\mathrm{RW}$ & $\mathrm{FW}$ & $\mathrm{TW}$ \\
\hline Chloroform & $<\mathrm{LD}^{\mathrm{a}}$ & 87.4 & 26.9 \\
Bromodichloromethane & $<\mathrm{LD}^{\mathrm{a}}$ & $<\mathrm{LOQ}$ & $<\mathrm{LOQ}$ \\
Dibromochloromethane & $<\mathrm{LD}^{\mathrm{b}}$ & $<\mathrm{LD}^{\mathrm{b}}$ & $<\mathrm{LD}^{\mathrm{b}}$ \\
Bromoform & $<\mathrm{LD}^{\mathrm{c}}$ & $<\mathrm{LD}^{\mathrm{c}}$ & $<\mathrm{LD}^{\mathrm{c}}$ \\
\hline Herbicides & & & \\
\hline Ametrine & 0.29 & $<\mathrm{LOQ}^{\mathrm{d}}$ & $<\mathrm{LOQ}^{\mathrm{d}}$ \\
Atrazine & 8.21 & 10.31 & 7.24 \\
Simazine & 3.04 & 2.49 & 1.36 \\
Picloran & $<\mathrm{LOQ}^{\mathrm{d}}$ & $<\mathrm{LOQ}^{\mathrm{d}}$ & $<\mathrm{LOQ}^{\mathrm{d}}$ \\
Tebuthiuron & 0.01 & 0.01 & $<\mathrm{LOQ}^{\mathrm{d}}$ \\
\hline
\end{tabular}

Abbreviations: RW is raw water, $\mathrm{FW}$ is filtered water and TW is treated water.

LD: limit of detection ${ }^{\mathrm{a}}<1 \mu \mathrm{g} \mathrm{L}^{-1}$

LD: limit of detection ${ }^{\mathrm{b}}<2 \mu \mathrm{g} \mathrm{L}^{-1}$

LD: limit of detection ${ }^{\mathrm{c}}<5 \mu \mathrm{g} \mathrm{L}^{-1}$

LOQ: limit of quantification ${ }^{\mathrm{d}}$

\subsection{Toxicity tests and data analysis}

The $H$. attenuata cnidarian bioassay failed to demonstrate toxicity in nearly all of the FW and TW samples or in RW samples with two exceptions: RW and FW samples collected in December yielded $96 \mathrm{~h}$-EC50s $=80 \%$, indicative of marginal sub-lethal toxic effects produced by these samples (Table 4). Arkhipchuk et al. (2006) also reported that H. attenuata could be successfully used for toxicity assessment of treated waters destined for human consumption.

Toxicity results in RW, FW and TW determined for the chlorophyte P. subcapitata are reported in Table 4. For RW, with the exception of the May and December samples, where $72 \mathrm{~h}-\mathrm{IC} 50 \mathrm{~s}$ were respectively of 66.9 and $33.4 \%$, all other samples were devoid of toxic effects. Correlation analysis indicates a link between $\mathrm{pH}$ and algal toxicity $(\mathrm{R}=0.89$; $p<0.05$ ), suggesting that $\mathrm{pH}$ may have at least partially contributed to phytotoxicity test results. Indeed, algal toxicity is highest $(72 \mathrm{~h}-\mathrm{IC} 50=33.4 \%$ in December (Table 4$)$ when 
sample $\mathrm{pH}$ is lowest ( $\mathrm{pH}=5.8$ in December, Table 2). Algal bioassay results for FW and TW show that all samples were toxic (Table 4). IC50s for FW are negatively correlated with free chlorine $(\mathrm{R}=-0.87 ; p<0.05)$ corroborating higher toxicity responses (i.e., decreasing IC50 values) with increasing chlorine concentrations. This is not surprising, as primary producers such as microalgae suffer growth inhibition effects when reactive chlorine species surpass levels of $180 \mu \mathrm{g} \mathrm{L}^{-1}$ (Kott et al., 1966). TW samples were even more toxic than FW samples as all IC50s were $<12.5 \%$, the lowest concentration tested with this bioassay. The higher levels of free chlorine present in TW samples (Table 2) are, again, allegedly responsible for the observed algal toxicity. When sodium thiosulphate was added to FW and TW samples, algal toxicity was completely eliminated, confirming once again its link with free chlorine (Table 4).

In October 2010, THMs were analyzed and quantified in FW and TW (Table 3) ranging from about $3 \mu \mathrm{g} \mathrm{L}^{-1}$ (bromodichloromethane, TW) to $87.4 \mu \mathrm{g} \mathrm{L}^{-1}$ (chloroform, FW). These levels are inferior to those required to elicit toxicity in algal species. Indeed, for the most susceptible algal species, reduced growth in blue-green and green algae exposed to THMs has been reported at concentrations of approximately $185 \mathrm{mg} \mathrm{L}^{-1}$ by Bringmann and Kühn (1978), thereby excluding THMs in having played a part in the phytotoxic effects observed in the present study. Similarly, the concentrations of herbicides measured in October 2010 in RW, FW and TW are low for causing algal toxicity (Table 3). For example, 96 h-IC50 bioassays performed with $S$. capricornutum (today called $P$. subcapitata) for atrazine yielded endpoint values of $128.2 \mu \mathrm{g} \mathrm{L}^{-1}$ and $130 \mu \mathrm{g} \mathrm{L}^{-1}$ (Gala and Giesy, 1990; Hoberg, 1991). Using the same algal species, a $96 \mathrm{~h}$-IC50 of $1240 \mu \mathrm{g} \mathrm{L}^{-1}$ was reported for simazine (Fairchild et al., 1997). Again, toxicity toward S. capricornutum exposed to tebuthiuron (Blaise and Harwood, 1991) cited a $96 \mathrm{~h}$-IC50 $=0.1 \mathrm{mg} \mathrm{L}^{-1}$, an endpoint value 10,000 times higher than the concentration found in RW and FW for this herbicide (Table 3). The algal toxicity observed in May and December for RW, probably are due to the presence of herbicides. Armas et al. (2005) and Monteiro et al. (2008) found residues of ametrine, glyphosate, 2,4-D, diuron, methribuzin, sulfentrazone, throughout the year on samples of Corumbataí River water.

Ecotoxicity data determined using water fleas are reported in Table 4. D. magna bioassays performed on RW samples were all exempt of toxic effects (LC50s $>100 \%$ ), supporting all other bioassay results that Corumbataí River water quality is free from toxicity at the point where it is taken up for the WTP drinking water process. Daphnids are known for their marked sensitivity to chlorinated water. For example, Fisher et al. (1999) reported a $48 \mathrm{~h}$-LC50 of $32 \mu \mathrm{g} \mathrm{L}^{-1}$ for the water flea, D. magna, exposed to reactive chlorine species. Hence, this likely explains their toxic responses in both chlorine-laden FW and TW samples, although no significant correlation was observed between free chlorine and LC50s in these waters $(\mathrm{R}=-0.41 ; p=0.49$ in $\mathrm{FW}$ and $\mathrm{R}=-0.040 ; p=0.94$ in $\mathrm{TW})$. While production of THMs during WTP process in FW and TW could also be claimed to have contributed to the toxicity of these micro-invertebrates, this is not supported by the scientific literature (LeBlanc, 1980; Abernethy et al., 1986), which situates the range of THM toxicity to D. magna between 29 to $78.9 \mathrm{mg} \mathrm{L}^{-1}$ for $48 \mathrm{~h}-\mathrm{LC} 50 \mathrm{~s}$, endpoint values which are superior to THM concentrations quantified in FW and TW in October 2010 (Table 4).

The herbicide levels reported in October 2010 for RW, FW and TW were also low to elicit toxicity toward cladocerans (Table 3). Atrazine toxicity to D. magna, for example, was reported to be in the range of $49 \mathrm{mg} \mathrm{L}^{-1}$ (Putt, 1991). For simazine, $48 \mathrm{~h}$-LC50s for D. magna were scored at 1 and $3.5 \mathrm{mg} \mathrm{L}^{-1}$ by Sanders (1970) and Marchini et al. (1988), respectively. For tebuthiuron, D. magna toxicity was estimated to be $100 \mathrm{mg} \mathrm{L}^{-1}$ (Meyerhoff et al., 1985). Interactions between free chlorine, THMs and/or herbicides found in FW and TW in October 2010 cannot, however, be excluded as a possible explanation for at least some of the observed toxicity toward daphnids. Lastly, sodium thiosulphate addition $(0.18 \%)$ to $\mathrm{FW}$ and $\mathrm{TW}$ 
samples, as occurred with algae, completely eliminated daphnid toxicity (LC50 > 100\% v/v) in all samples (Table 4).

Table 4. Toxicity to P. subcapitata (IC50-96 h), D. magna (LC50-46 h) and H. attenuata (EC50-96 h) in water samples, of Corumbataí River collected from March to December, 2010 at WTP. Values are expressed in $\% \mathrm{v} / \mathrm{v}$.

\begin{tabular}{l|ccc|ccc|ccc}
\hline \multirow{2}{*}{$\begin{array}{c}\text { Sampling } \\
\text { Period }\end{array}$} & \multicolumn{3}{|c}{ P. subcapitata } & \multicolumn{3}{c|}{ D. magna } & \multicolumn{3}{c}{ H.attenuata } \\
\cline { 2 - 9 } & RW & FW $^{\mathbf{b}}$ & $\mathbf{T W}^{\mathbf{b}}$ & $\mathbf{R W}$ & $\mathbf{F W}^{\mathbf{b}}$ & $\mathbf{T W}^{\mathbf{b}}$ & $\mathbf{R W}$ & $\mathbf{F W}^{\mathbf{b}}$ & $\mathbf{T W}^{\mathbf{b}}$ \\
\hline March & $>100$ & $<12.5^{\mathrm{a}}$ & $<12.5$ & $>100$ & $<12.5$ & $<12.5$ & $>100$ & $>100$ & $>100$ \\
May & 66.9 & 26.0 & $<12.5$ & $>100$ & 55.3 & $<12.5$ & $>100$ & $>100$ & $>100$ \\
July & $>100$ & $<12.5$ & $<12.5$ & $>100$ & $>100$ & $<12.5$ & $>100$ & $>100$ & $>100$ \\
October & $>100$ & 19.7 & $<12.5$ & $>100$ & 35.4 & $<12.5$ & $>100$ & $>100$ & $>100$ \\
December & 33.4 & 36.2 & $<12.5$ & $>100$ & 95.3 & 15.6 & 89.0 & 80.2 & $>100$ \\
\hline
\end{tabular}

Abbreviations: raw water (RW), filtered water (FW) and treated water (TW). ${ }^{\mathrm{a}}$ Concentration of $12,5 \% \mathrm{v} / \mathrm{v}$, was the lowest tested. ${ }^{\mathrm{B}}$ Addition of Na thiosulphate $(0.18 \%)$ to water samples completely eliminated toxicity (LC50 or IC50 $>100 \% \mathrm{v} / \mathrm{v}$ ) in all samples.

\subsection{Redundancy analysis}

RDA performed on October 2010 data (Figure 2) confirms an association among trihalomethanes (chloroform and bromodichloromethane) and free chlorine, an unexpected relationship. This is due to the fact that THMs are formed as byproducts from organic and chlorine interactions in WTPs. Free chlorine, in particular, because of its long arrow line and opposite direction to lines of D. magna and P. subcapitata, is apparently linked to toxicity responses of these aquatic organisms (Figure 1). RDA also does not show any association between herbicides (atrazine and simazine) and toxicity to these same organisms, as previously suggested by Pearson-moment correlation analysis. However, long-term health effects for human consumers of drinking water cannot be excluded, as atrazine and simazine were found at levels exceeding Brazilian regulations for drinking water.

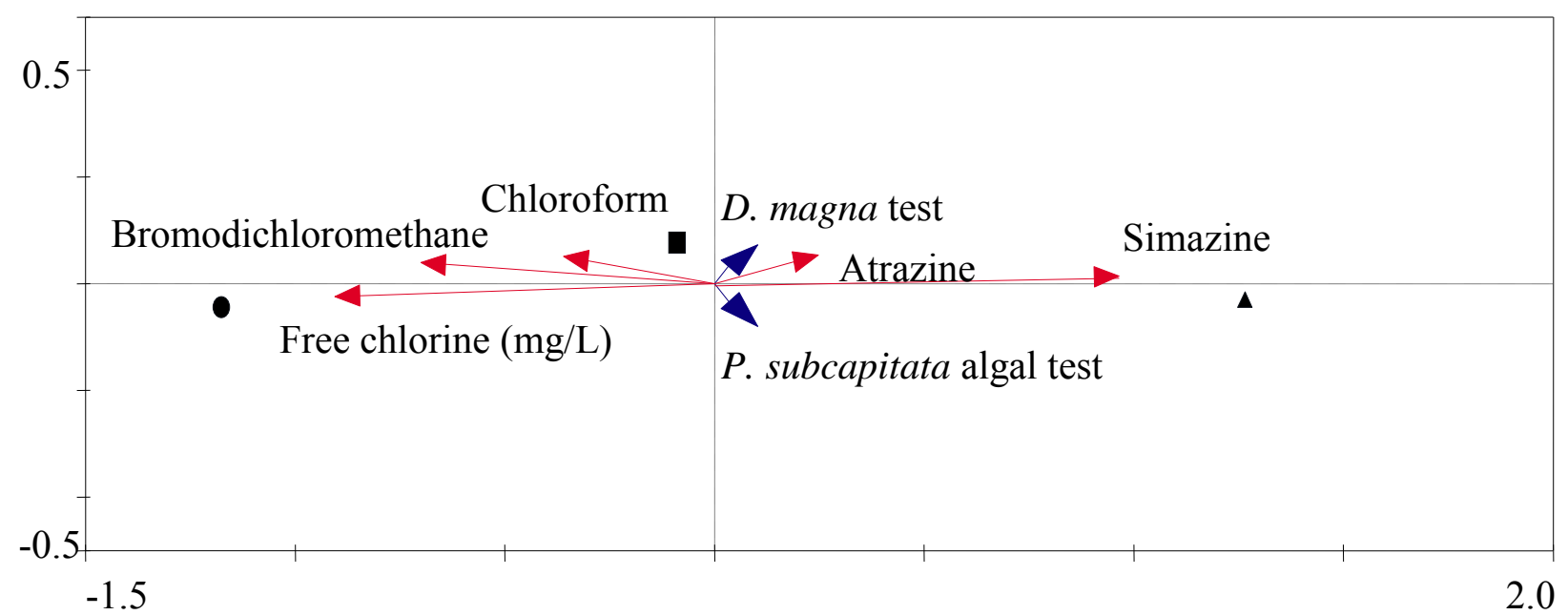

Figure 2. Redundancy analysis (RDA) exploring relationships with toxicity responses of algae $P$. subcapitata and D. magna versus trihalomethane and herbicide residue concentrations for the October 2010 data, present in RW ( $)$, FW (ם) and TW (•). 
Finally, it is worth mentioning that the Corumbataí River could possibly be influenced by other classes of chemical contaminants. Indeed, the presence of Bisphenol A and caffeine has been recently reported (Raimundo, 2011), and this may suggest that the Corumbataí River could likely be the recipient of a yet undetermined load of pharmaceutical residues. In fact, Raimundo (2011) investigated assessing the removal of 16 priority organic micro-pollutants by the WTP. Atrazine was found in sampled water during two sampling outings to the Corumbataí River in 2011. Atrazine levels ranged from 4.8 to $7.5 \mathrm{ng} \mathrm{L}^{-1}$ in Corumbataí River water (RW), while they ranged from 4.7 to $16.5 \mathrm{ng} \mathrm{L}^{-1}$ in WTP treated water, indicating the treatment did not eliminate atrazine residues. Again, Bisphenol A concentrations in raw water ranged between 5.7 to $27.3 \mathrm{ng} \mathrm{L}^{-1}$ and between $<0.5$ to $2.2 \mathrm{ng} \mathrm{L}^{-1}$ in drinking water. In comparison, an atrazine concentration of $9.3 \mu \mathrm{g} \mathrm{L}^{-1}$ was reported in a surveillance study of drinking water in the U.S.A. (Benotti et al., 2009). These recent findings guarantee future investigations to assess whether these classes of emerging substances could be hazardous to aquatic life and human health (Umbuzeiro, 2012).

\section{CONCLUSIONS}

This investigation demonstrated that coupling ecotoxicological tests, physical and chemical analysis proved valuable to monitor the water quality of the Corumbataí River, and that of its treated waters processed by the Water Treatment Plant (WTP) of Piracicaba, SP, Brazil. Global data amassed enabled us to optimize interpretation associated with the water quality of raw, filtered and treated samples, as well as to uncover some cause-effect relationships existing between physical, chemical and toxicity results.

\section{ACKNOWLEDGEMENTS}

We are grateful to CNPq for the financial support (474948/2009-9). Appreciation is extended to CNPq, CAPES and FAPESP for the research grants.

\section{REFERENCES}

ABERNETHY, S.; BOBRA, A. M.; SHIU, W. Y.; WELLS, P. G.; MACKAY, D. Acute lethal toxicity of hydrocarbons and chlorinated hydrocarbons to two planktonic crustaceans: The key role of organism-water partitioning. Aquatic Toxicology, v. 8, p. 163-174, 1986. http://dx.doi.org/10.1016/0166-445X(86)90062-7

AMERICAN PUBLIC HEALTH ASSOCIATION - APHA AMERICAN WATER WORKS ASSOCIATION - AWWA; WATER ENVIRONMENT FEDERATION - WEF. Standard methods for the examination of water and wastewater. 20. ed. Washington, DC 2005.

ARAÚJO, M. C.; OLIVEIRA, M. B. M. Monitoramento da qualidade das águas de um riacho da Universidade. Revista Ambiente \& Água, v. 8, n.3 p. 247-257, 2013. http://dx.doi.org/10.4136/ambi-agua. 1192

ARKHIPCHUK, V. V.; BLAISE, C.; MALINOVSKAYA, M. V. Use of Hydra for chronic toxicity assessment of waters intended for human consumption. Environmental Pollution, v. 142, p. 200-211, 2006. http://dx.doi.org/10.1016/j.envpol.2005.10.012 
ARMAS, E. D.; MONTEIRO, R. T. R.; AMÂNCIO, A. V.; CORREA, R. M. L.; GUERCIO, M. A. Uso de agrotóxicos em cana-de-açúcar na bacia do rio Corumbataí e o risco de poluição hídrica. Química Nova, v. 28, p. 975-982, 2005. http://dx.doi.org/10.1590/S0100-40422005000600008.

BENOTTI, M. J.; TRENHOLM, R. A.; VAN DER FORD, B. J.; HOLADY, J. C.; STANFORD, B. D.; SNYDER, S. A. Pharmaceuticals and endocrine disrupting compounds in U.S. drinking water. Environment Science Technology, v. 43, p. 597603, 2009. http://dx.doi.org/10.1021/es801845a.

BLAISE, C.; FORGET, G.; TROTTIER, S. Toxicity screening of aqueous samples using a cost-effective 72-h exposure Selenastrum capricornutum assay. Environmental Toxicology, v. 15, p. 352-359, 2000. http://dx.doi.org/10.1002/15227278(2000)15:4<352::AID-TOX12>3.0.CO;2-L

BLAISE, C.; HARWOOD, M. Contribution à l'évaluation écotoxicologique du Tébuthiuron - un herbicide de la classe des urées substituées. Revue des Sciences de l' Eau, v. 4, p. 121-134, 1991.

BLAISE, C.; KUSUI, T. Acute toxicity assessment of industrial effluents with a microplatebased Hydra attenuata assay. Environment Toxicology of Water Quality, v. 12, p. 5360, $1997 . \quad \mathrm{http}: / / \mathrm{dx}$. doi.org/10.1002/(SICI)1098-2256(1997)12:1<53::AIDTOX8>3.0.CO;2-7

BRASIL. Ministério da Saúde. Portaria $n^{\circ}$ 2.914/2011. Procedimentos de controle e de vigilância da qualidade da água para consumo humano e seu padrão de potabilidade. Diário Oficial da União, Seção 1, p. 39-46, 2011.

BRINGMANN, G.; KÜHN, R. Limiting values for the noxious effects of water pollutant material to blue algae (Microcystis aeruginosa) and green algae (Scenedesmus quadricauda) in the cell multiplication inhibition test. Vom Wasser, v. 50, p. 45-60, 1978.

CUELA, M.; COZAR, O.; RISTOIU, D. Methods validation for the determination of trihalomethanes in drinking water. Journal of Mass Spectrometry, v. 41, p. 15941597, 2006. http://dx.doi.org/10.1002/jms.1149

ENVIRONMENT CANADA. Biological test method: acute lethality test using Daphnia species, amended version. Ottawa, 1996. (EPS 1/RM/11).

FAIRCHILD, J. F.; RUESSLER, D. S.; HEVERLAND, P. S.; CARLSON, A. R. Comparative sensitivity of Selenastrum capricornutum and Lemna minor to sixteen herbicides. Archives of Environmental Contamination and Toxicology, v. 32, p 353-357, 1997. http://dx.doi.org/10.1007/s002449900196

FARLAND, W. H.; GIBB, H. J. U. S. Perspective on balancing chemical and microbial risks of disinfection. In: CRAU, G. (Ed.). Safety of Water Disinfection: balancing chemical and microbial risks. Washington, DC: ILSI Press, 1993. p. 3-10.

FISHER, D. J.; BURTON, D. T.; YONKOS, L. T.; TURLEY, S. D.; ZIEGLER G. P. The relative acute toxicity of continuous and intermittent exposures of chlorine and bromine to aquatic organisms in the presence and absence of ammonia. Water Research, v. 33, p. 760-768, 1999. http://dx.doi.org/10.1016/S0043-1354(98)00278-4 
GALA, W. R.; GIESY, J. P. Flow cytometric techniques to assess toxicity to algae. In: VAN DER SHALIE, W. H.; LANDIS, W. G. Aquatic toxicology and risk assessment: thirteenth volume. Philadelphia: ASTM, 1990. p. 237-246. (STP, 1096).

HAIR, J. F.; TAHAM, R. L.; BLACK, W. C. Multivariate data analysis. 4. ed. New Jersey: Prentice Hall, 1995.

HOBERG, J. R. Atrazine technical-toxicity to the freshwater green alga Selenastrum capricornutum. Duluth: USEPA, 1991. (MRID No. 420607-01).

KOTT, Y.; HERSHKOVITZ, G.; SHEMTOB, A.; SLESS, J. B. Algicidal effect of bromine and chlorine on Chlorella pyrenoidosa. Applied Microbiology, v. 14, p. 8-11, 1966.

LEBLANC, G. A. Acute toxicity of priority pollutants to water flea (Daphnia magna). Bulletin of Environmental Contamination and Toxicology, p. 24, p. 684-691, 1980. http://dx.doi.org/10.1007/BF01608174

MARCHINI, S.; PASSERINI, L.; CESAREO, D.; TOSATO M. L. Herbicidal triazines: Acute toxicity on Daphnia, fish, and plants and analysis of its relationships with structural factors. Ecotoxicology and Environmental Safety, v. 16, p. 148-157, 1988. http://dx.doi.org/10.1016/0147-6513(88)90029-2

MEYERHOFF, R. D.; GROTHE, D. W.; SAUTER, S.; DORULLA, G. K. Chronic toxicity of tebuthiuron to an alga (Selenastrum capricornutum) a cladoceran (Daphnia magna) and the fathead minnow (Pimephales promelas). Environmental Toxicology and Chemistry, p. 4, p. 695-701, 1985. http://dx.doi.org/10.1002/etc.5620040513

MONTEIRO, R. T. R.; ARMAS, E. D.; QUEIROZ, S. C. N. Lixiviação e contaminação das águas do rio Corumbataí por herbicidas. In: CONGRESSO BRASILEIRO DA CIÊNCIA DAS PLANTAS DANINHAS, 26.; CONGRESO DE LA ASOCIACIÓN LATINO-AMERICANA DE MALEZAS, 18., 2008, Ouro Preto. A ciência das plantas daninhas na sustentabilidade dos sistemas agrícolas. Ouro Preto: SBCPD, 2008. p. 181-192.

PASCHOALATO, C. F. P. R.; TRIMAILOVAS, M. R.; DI-BERNARDO, L. Formação de subprodutos orgânicos halogenados nas operações de pré-oxidação com cloro, ozônio e peroxônio e pós-cloração em água contendo substâncias húmicas. Engenharia Sanitária e Ambiental, v. 13, p. 313-322, 2008. http://dx.doi.org/10.1590/S141341522008000300011

PUTT, A. E. Acute toxicity to daphnids (Daphnia magna) under flow-through conditions. Duluth: USEPA, 1991. (MRID No. 420414-01).

QUINTANA, J.; MARTÍ, I.; VENTURA, F. Monitoring of pesticides in drinking and related waters in NE Spain with a multiresidue SPE-GC-MS method including an estimation of the uncertainty of the analytical results. Journal Chromatography A, v. 938, p. 3-13, 2001. http://dx.doi.org/10.1016/S0021-9673(01)01168-2

RAIMUNDO, C. C. M. Contaminantes emergentes em água tratada e seus mananciais: sazonalidade, remoção e atividade estrogênica. 2011. Tese (Doutorado em Ciências) - Instituto de Química, Universidade Estadual de Campinas, Campinas, 2011.

SANDERS, H. O. Toxicities of some herbicides to six species of freshwater crustaceans. Journal of Water Pollution Control Federation, v. 42, p. 1544-1550, 1970. http://www.jstor.org/stable/25036743 
SANTOS, M. A. P. F. Sensitivity of four test organisms (Chironomus xanthus, Daphnia magna, Hydra attenuata and Pseudokirchneriella subcapitata)to $\mathrm{NaCl}$ : an alternative reference toxicant. Journal of Brazilian Society of Ecotoxicology, v. 2, p. 229-236, 2007.

SANTOS, S. M.; GOUVEIA, N. Presença de trihalometanos na água e efeitos adversos na gravidez. Revista Brasileira de Epidemiologia, v. 14, p.106-119, 2011. http://dx.doi.org/10.1590/S1415-790X2011000100010

SCHÄFER, R. B.; VON DER OHE P. C.; KÜHNE, R.; SCHÜÜRMANN, R. G.; LIESS, M. Occurrence and toxicity of 331 organic pollutants in large rivers of north Germany over a decade (1994 a 2004). Environmental Science \& Technology, v. 45, p. 6167-6174, 2011. http://dx.doi.org/10.1021/es2013006

SERRANO, A.; GALLEGO, M. Rapid determination of total trihalomethanes index in drinking water. Journal Chromatography A, v. 1154, p. 26-33, 2007. http://dx.doi.org/10.1016/j.chroma.2007.03.101

SILVA, G. H.; MESSIAS, T. G.; LEME, D. M.; MONTEIRO, R. T. R. Mutagenicidade e genotoxicidade em águas superficiais e subterrâneas antes e após o tratamento da água. Holos Environment, v. 13, p. 64-73, 2013.

UMBUZEIRO, G. A. (Cord.) Guia de potabilidade para substâncias químicas. São Paulo: Abes, 2012. $144 \mathrm{p}$.

UNIVERSIDADE DE SÃO PAULO. Escola Superior de Agricultura Luiz de Queiroz. Estação Meteorológica da ESALQ/USP. Piracicaba, 2011. Available at: http://www.leb.esalq.usp.br/exceldados/DCE2011.TXT. Accessed at: June 132011.

VILLANUEVA, C. M.; CANTOR, K. P.; GRIMALT, J. O.; MALATS, N.; SILVERMAN, D.; TARDON, A. et al. Bladder cancer and exposure to water disinfection by-products trough ingestion, bathing, showering and swimming in pools. American Journal of Epidemiology, v. 165, p. 148-156, 2007. http://dx.doi.org/10.1093/aje/kwj364

WORLD HEALTH ORGANIZATION - WHO. Guidelines for drinking water quality. 2. ed. Geneva, 1996. v. 2, p. 849-872.

WORLD HEALTH ORGANIZATION - WHO. Guidelines for drinking water quality. First addendum to 3. ed. Recommendations. Geneva, 2006. v. 1. 


Ambiente \& Água - An Interdisciplinary Journal of Applied Science
ISSN 1980-993X - doi:10.4136/1980-993X
www.ambi-agua.net
E-mail: ambi-agua@agro.unitau.br

\title{
Exposure to occupational dust and changes in pulmonary function among cobblestone paving workers of Jimma, Ethiopia
}

\author{
doi: 10.4136/ambi-agua.1227
}

Received: 22 Oct 2013; Accepted: 08 Mar. 2014

\author{
Kalkidan Abate Hassen*; Mohammed Sadik Ibrahim \\ Jimma University (JU) - Jimma, Oromia Region, Ethiopia \\ College of Public Health and Medical Sciences \\ *Corresponding author: e-mail: kalkidan.hassen@ju.edu.et, \\ mohaisadik@yahoo.com
}

\begin{abstract}
The classic diseases of "dusty" occupations may be on decline, but they are not yet extinct. Studies have found associations between changes in ambient particulate air pollution and increased cardiorespiratory morbidity and mortality. A cross-sectional comparative study design was employed on 127 male nonsmoker cobblestone paving workers and 194 matched employed office workers as a reference in order to assess changes in pulmonary function related to dust exposure among cobblestone road paving workers of Jimma zone, Ethiopia. Data was collected using structured questionnaires and spirometric measurements after ethical clearance was obtained. Data was analyzed using unpaired t-tests to examine the differences between the groups. P-values equal or less than 0.05 were considered statistically significant; odds were calculated at a 95\% confidence interval. Cobblestone road paving workers had significantly higher odds of respiratory symptoms, dry cough $(\mathrm{p}<0.05)$, cough $(\mathrm{p}<0.01)$ and sore throat $(\mathrm{p}<0.001)$ compared to the reference. The FEV1 for workers exposed to cobblestone road paving workers ranged between $3.12-4.73 \mathrm{~L}$, with a mean of $3.96 \pm 0.6 \mathrm{~L}$, significantly lower than the reference groups who had a range of $3.3-4.78 \mathrm{~L}$ and a mean of $4.01 \pm 0.6 \mathrm{~L}(\mathrm{p}<0.05)$. The mean value of the ratio of FEV1/FVC was significantly decreased in the cobblestone road paving workers compared to the controls (87.2 (SD 4.3) v 89.5 (SD 5.4), $\mathrm{p}=0.01$ ). In conclusion, the study revealed clear evidence of the need for health education and for the promotion of activities directed towards mitigating respiratory hazards in order to foster a safe and healthy work environment.
\end{abstract}

Keywords: air pollution, dust exposure, particulate matter, pulmonary function.

\section{Exposição à poeira e alterações na função pulmonar entre trabalhadores de pavimentação com pedregulhos em Jimma, Etiópia}

\section{RESUMO}

As doenças clássicas associadas com trabalhos em ambientes empoeirados podem estar diminuindo, porém ainda não extintas. Estudos realizados associaram mudanças na poluição do ar em ambientes empoeirados com o aumento da morbidade e mortalidade cardiorrespiratória. Neste estudo comparativo transversal foram analisados 127 trabalhadores masculinos de pavimentação de estradas com pedregulhos, não fumantes e que foram 
comparados com 194 trabalhadores de escritório utilizados como referência para avaliar as alterações da função pulmonar relacionadas à exposição ao pó na zona de Jimma, Etiópia. Os dados foram coletados por meio de questionário estruturado após a autorização do Comitê de Ética e realizada a mensuração espirométrica. Os dados foram analisados utilizando-se o teste $\mathrm{t}$ não pareado para analisar a diferença entre os grupos. Valores de $\mathrm{p}$ igual ou menor que 0,05 foram considerados estatisticamente significativos e as razões de possibilidades foram calculadas com intervalo de confiança de $95 \%$. Trabalhadores de pavimentação de estrada tiveram uma razão de possibilidade significativamente maior de sintomas respiratórios, como tosse seca $(\mathrm{p}<0,05)$, tosse $(\mathrm{p}<0,01)$ e dor de garganta $(\mathrm{p}<0,001)$ em relação ao grupo de referência. O FEV1 para trabalhadores expostos ao trabalho de pavimentação de estrada variou entre 3,12 - 4,73 L com uma média de 3,96 $\pm 0,6 \mathrm{~L}$ significativamente menor do que os grupos de referência que apresentaram um intervalo de 3,3 - 4,78 L e média de 4,01 $\pm 0,6 \mathrm{~L}$ $(\mathrm{p}<0,05)$. O valor médio da relação de FEV1/FVC foi significativamente menor para trabalhadores de pavimentação de estrada em comparação com o grupo de controle (87,2 (dp 4,3) contra 89,5 (dp 5,4); p = 0,01). Em conclusão, o estudo revelou evidências claras da necessidade de educação e promoção da saúde voltada para riscos respiratórios para promover um ambiente de trabalho seguro e saudável.

Palavras-chave: poluição do ar, exposição à poeira, partículas em suspensão, função pulmonar.

\section{INTRODUCTION}

The classic diseases of "dusty" occupations may be on the decline; but they are not yet extinct. According to the World Health Organization (WHO), almost one-third of the global disease burden can be attributed to environmental risk factors (Prüss-Üstün and Corvalán, 2006). WHO also has listed dust-producing operations that include sandblasting, rock drilling, stone cutting, sawing, chipping, grinding, polishing, breaking of sand molds, "shake-out", granule handling operations such as weighing and mixing and transferring dusty raw materials and products, which are typical of cobblestone paving work operations. Workers today still suffer from a variety of illnesses caused by dust they inhaled from the work environment, including acute and chronic respiratory functional impairment (WHO, 1999).

Cobblestone paving is a simple and replicable technology; its ability to create thousands of jobs is impressive. More than 20 towns in Ethiopia, including Addis Ababa, have now institutionalised cobblestone paving construction. A poor road network, expensive asphalt roads, declining economic activities, increased poverty and unemployment were some of the factors which influenced the city to find a road building technology that was labour-intensive, durable and easy to maintain (Ethiopia, 2011). However, like most road works, it presents respiratory occupational concerns which are worthy of study.

Many studies have found associations between daily changes in ambient particulate air pollution and increased cardiorespiratory hospital admissions, along with cardiorespiratory mortality (Nyberg and Pershagen, 2000). One approach to assessing the potential chronic effects of air pollution is to determine changes on lung functions by measuring volumes and determining lung capacities. Spirometry is the most common of all pulmonary function tests used to diagnose and monitor respiratory problems. Moreover, the measurement and monitoring of lung volume and capacity in order to rate occupational hazard is used to produce norms or policies related to preventive measure against occupational air pollutants (NIOSH, 2012).

According to a recent review of chronic obstructive pulmonary disease (COPD), $25 \%$ to $45 \%$ of patients diagnosed with the disease have never smoked, which makes occupational exposure as an attributing cause of COPD more likely (Salvi and Barnes, 2009). In developed countries, an estimated $15 \%$ of all COPD is attributable to occupational exposure (Hnizdo and 
Vallyathan, 2003). A Malaysian study has shown association of total dust exposure and respiratory symptoms such as cough, phlegm, chest tightness and also with lung function indices (Noor et al., 2000). Similarly, in panel studies, acute episodes of particulate air pollution have been associated with increased incidence of respiratory symptoms, and decreased lung functions (Pope et al., 1995).

In order to minimize occupation-related pulmonary risk of air pollution, prevention and continuous monitoring systems are necessary to provide norms for adequate personal respiratory protective measures for chronically exposed people. Thus, this study aimed to show existing changes in pulmonary function related to dust exposure, if any, and to generate evidence to integrate primary prevention methods towards dust-related mortality and morbidity.

\section{METHOD}

The study was conducted in Jimma town, located in the Oromia province of Ethiopia, $354 \mathrm{~km}$ South West of the capital Addis Ababa. The town has a temperature that ranges from $20-30{ }^{\circ} \mathrm{C}$ and with average annual rainfall of $800-2500 \mathrm{~mm}^{3}$. The town has an altitude of $1750-2000 \mathrm{~m}$ above sea level. A cross-sectional comparative study design was employed on 127 male nonsmoker cobblestone paving workers and 194 nonsmoker government-employed office workers as a reference. Sample size was calculated using OpenEpi info software assuming two-sided confidence level (1-alpha) of 95, a Power of 80, a ratio of Controls to Cases of two, a hypothetical proportion of controls with an exposure of 40, a hypothetical proportion of cases with exposure of 57.14 with least extreme Odds Ratio to be detected of 2.00 of non-response rate of $15 \%$. Data was collected using a structured questionnaire and spirometric measurement using lung function measurement was performed using a portable digital Spirometer (Vitalograph 2120), after ethical clearance was obtained from the review board of the College of Public Health and Medical Sciences, Jimma University, Ethiopia. Cobblestone paving workers were matched with the reference by confounding factors to increase the efficiency of statistical analysis. Age, sex, weight and height were used for matching. The reference subjects were randomly selected after the number of study subjects (cobblestone paving workers) was saturated. Subjects who take short-acting bronco dilators or had medically diagnosed pulmonary disease or who had been on an anti-Tuberculosis drug for the preceding six months, workers with any form of oral lesion or bleeding, subjects with an active upper respiratory infection and with chest deformities were excluded. Data was analyzed using unpaired t-tests to examine the difference between the groups. P-values equal or less than 0.05 were considered statistically significant. Odds were calculated at a $95 \%$ confidence interval).

\section{RESULTS}

\subsection{Socio-demographic characters}

Among 321 respondents, 194 were government-employed office workers and 127 were cobblestone paving workers. Respondents were comparable among the groups, with a mean (sd) age of $26.4 \pm 9$ years for cobblestone and $27 \pm 5$ for the reference (Table1). The reference groups were more educated (grouped) compared to cobblestone paving workers ( $2 \pm 1.2 \mathrm{vs}$. $3 \pm 1.4$, where primary, secondary and territory levels educations are assumed hierarchically). Similarly, the reference groups had worked more years at their current jobs than compared to the cobblestone workers ( $3.3 \pm 1.4$ vs. $7 \pm 3.9$ years $)$. 
Table1. Comparisons of the study subjects and the reference population in Jimma, Ethiopia, 2013.

\begin{tabular}{l|ccc}
\hline \multicolumn{1}{c|}{ Variables } & $\begin{array}{c}\text { Cobblestone workers } \\
\mathrm{N}=127\end{array}$ & $\begin{array}{c}\text { Reference group } \\
\mathrm{N}=194\end{array}$ & P value \\
\hline Age & $26.4 \pm 9$ years & $27 \pm 5$ & 0.65 \\
Duration at current work & $3.3 \pm 1.4$ years & $7 \pm 3.9$ & $0.02^{*}$ \\
Weight & $59 \pm 9.6 \mathrm{~kg}$ & $61 \pm 7.7$ & 0.32 \\
height & $162 \pm 8.3 \mathrm{~kg}$ & $163 \pm 4.2$ & 0.53 \\
Educational status (grouped) & $2 \pm 1.2$ & $3 \pm 1.4$ & $0.01 *$ \\
\hline
\end{tabular}

*significant.

The study result showed (Table 2) that Cobblestone paving workers had a higher frequency and odds of respiratory symptoms. Having dry cough $(\mathrm{p}<0.05)$, Cough with sputum production $(\mathrm{OR}=4.957, \mathrm{p}<0.01)$ and sore throat $(\mathrm{OR}=5.842, \mathrm{p}<0.001)$ showed a significant statistical association compared to the reference. They also had a higher prevalence of dyspnea $9(7 \%)$, diagnosed lower respiratory infection $9(7 \%)$ and wheezing $8(6.2 \%)$, but were not statistically significant. Utilization of protective devices by cobblestone paving workers was $3.2 \%$. The most common reasons for not using protective devices were "dust of such kind don't harm" $65 \%$, "I don't have mask" $31 \%$, and "unmasking is better" $17 \%$.

Table 2. Occurrence and frequency of respiratory symptoms in last three months among cobblestone paving workers and references population in Jimma, Ethiopia, 2013.

\begin{tabular}{l|ccccc}
\hline \multicolumn{1}{c|}{$\begin{array}{c}\text { Respiratory } \\
\text { symptoms }\end{array}$} & $\begin{array}{c}\text { Cobblestone } \\
\text { workers } \\
\mathrm{n}=127\end{array}$ & $\begin{array}{c}\text { Reference } \\
\text { group } \\
\mathrm{n}=194\end{array}$ & OR & CI & P value \\
\hline Dry cough & $17(13.4 \%)$ & $11(5.6 \%)$ & 2.571 & $1.093-6.119$ & $0.028^{*}$ \\
dyspnea & $9(7 \%)$ & $10(5.2 \%)$ & 1.403 & $0.506-3.872$ & 0.634 \\
Cough with sputum & $12(9.4 \%)$ & $4(2 \%)$ & 4.957 & $1.439-18.689$ & $0.007^{*}$ \\
Sore throat & $17(13.4 \%)$ & $5(2.5 \%)$ & 5.842 & $1.956-18.660$ & $0.001^{*}$ \\
Chest wheezing & $8(6.2 \%)$ & $6(3.1 \%)$ & 1.890 & $0.578-6.309$ & 0.372 \\
Diagnosed LRTI** & $9(7 \%)$ & $7(3.6 \%)$ & 1.907 & $0.629-5.867$ & 0.316 \\
\hline
\end{tabular}

* Significant; **lower respiratory tract infection.

Spirometric measurement were recorded at ambient temperatures of $20-24^{\circ} \mathrm{C}$ and corrected to body temperature and pressure saturated with water vapor (BTPS). The mean (sd) of Forced Vital Capacity (FVC) of the cobblestone paving workers ranged between 3.7-5.1 L with a mean $4.4 \pm 0.5 \mathrm{~L}$ lower than the reference, who had a mean (sd) $4.5 \pm 0.6 \mathrm{~L}$, but not 
statistically significant (Table 3). The forced expiratory volume in one second (FEV1) of cobblestone paving workers ranged between $3.12-4.73 \mathrm{~L}$ with a mean of $3.96 \pm 0.6 \mathrm{~L}$, significantly lower than FEV1 of the reference subjects' FEV1, ranged 3.3-4.78 L and a mean of $4.01 \pm 0.6$.

Table 3. Comparisons of pulmonary volumes among cobblestone paving workers and references population in Jimma, Ethiopia, 2013.

\begin{tabular}{l|ccc}
\hline Pulmonary functions & $\begin{array}{c}\text { Cobblestone workers } \\
\text { Mean (sd) }\end{array}$ & $\begin{array}{c}\text { Reference group } \\
\text { Mean (sd) }\end{array}$ & P value \\
\hline FVC & $4.4(0.5)$ & $4.5(0.6)$ & 0.16 \\
FEV1 & $3.96(0.6)$ & $4.01(0.6)$ & $0.03^{*}$ \\
FEV1\% & $87.2(4.3)$ & $89.5(5.4)$ & $0.01^{*}$ \\
\hline
\end{tabular}

*Significant.

The mean value of the ratio of FEV1\% significantly decreased in the cobblestone paving workers compared to the reference $(87.2 \pm 4.3$ vs $89 . \pm 5.5, p=0.01)$. There appeared to be no statistically significant differences in FVC between cobblestone paving workers and the reference, although cobblestone paving tended to have lower lung function parameters. On the contrary, FEV1 and FEV1\% showed a significant reduction (Tables 3 and 4) among cobblestone paving workers $(\mathrm{P}<0.05)$. Tests for association conducted by independent $\mathrm{t}$ test with $95 \%$ CI revealed that there is a significant association between the duration of work in years and the FEV1. The result showed reduced FEV1 among cobblestone paving workers with longer durations of work $(\mathrm{P}<0.001)$.

Table 4. Duration of exposure (adjusted) and lung function among cobblestone paving workers: In dependent sample t-test, Jimma, Ethiopia. 2013.

\begin{tabular}{c|cccc}
\hline Lung function & F-Statistics & T & $\begin{array}{c}\text { P-value } \\
\text { (Two tailed test) }\end{array}$ & $\begin{array}{c}\text { 95\% Confidence Interval of } \\
\text { the Difference }\end{array}$ \\
\hline FVC & 6.25 & 2.48 & $0.013^{*}$ & $(0.01-0.09)$ \\
FEV1 & 20.01 & 4.01 & $0.000^{*}$ & $(0.06-0.17)$ \\
FEV1\% & 19.19 & 4.32 & $0.000^{*}$ & $(1.57-4.42)$ \\
\hline
\end{tabular}

*Significant.

\section{DISCUSSION}

Classic epidemiological studies revealed chronic dust exposure among the major risk factors for chronic obstructive lung disease, while the recent clinical and pathological experimental studies have contributed further towards elucidating the pathophysiological mechanism by which dust can cause alteration that leads to the development of the disease (Hnizdo and Vallyathan, 2003). Cobblestone paving work involves stone crushing which continuously generates significant amount of dust in the atmosphere. The present study showed that the burden of air pollution is not evenly shared among the groups. Cobblestone paving workers were found to have more respiratory symptom and reduced lung volume. The socio-demographic comparisons of the study revealed that cobblestone paving workers were less educated than their matched (age, sex, height and weight) references. Many studies have 
explored such differences in engagement with occupational hazardous work among less educated groups; such phenomenon was included in a workshop of the American Lung Association held in 2001 that focused on air pollution and health inequities (American Lung Association, 2001). The same finding was observed in a study done by O'Neill et al. (2012) and a review of Laurent et al. (2007).

More respiratory symptoms were found among exposed cobblestone paving workers than among the reference and were consistent with the Groneberg et al. (2006) review, which showed an aggregate of evidence focused on occupational causes of respiratory symptoms, particularly cough, being one of the most prevalent work-related airway symptoms. Similarly, Faria et al. (2006) and Schenker et al. (2005) also showed more respiratory symptoms among workers exposed to higher dust concentrations.

The spirometric data of the current study showed a lower but not a significant reduction in FVC measurements relative to the reference groups. However, FVC alone can't justify absence of alteration in pulmonary function as FVC can be normal or slightly decreased in patients with obstructive lung conditions (Gildea and McCarthy, 2003). Considering short duration of work for exposed groups, the lower FVC value is still clinically important as change in pulmonary parameters are the product of multiple years of exposure. There is a statistically significant reduction in FEV1 consistent with studies done by Jenny et al. (1960) and Yang et al. (1996) among workers exposed to cement and construction dust which was indicative of altered airway patency.

FEV1\% is significantly reduced among cobblestone paving workers, which is similar to studies done by Al-Neaimi et al. (2001) and Mwaiselage et al. (2004). The results also showed a significant reduction in FEV1\%, which indicates an obstructive impairment which could be due to mechanical irritation caused by exposed dust and individual susceptibility. Generally, the pulmonary function tests are more decreased in cobblestone workers as compared to the reference. Such pulmonary volume changes suggest an urgent need to improve dust control measures and health awareness towards dust prevention measures.

The data for use of protective devices was too small (3.2\%), as was knowledge regarding protective devices among the cobblestone workers, which further justifies the need for health education on the prevention of occupational hazards and more specifically on respiratory ailments related to air pollution.

\section{CONCLUSION}

In conclusion, our study showed adequate evidence of the need for health education and other activity directed towards the reduction of respiratory hazards in order to foster a safe and healthy work environment, which will in turn maintain and promote workers' health, working capacity and productivity.

\section{ACKNOWLEDGEMENTS}

We thank Jimma University for funding the study.

\section{REFERENCES}

AL-NEAIMI, Y. I.; GOMES, J.; LLOYD, O. L. Respiratory illnesses and ventilatory function among workers at a cement factory in a rapidly developing country. Occupational Medicine, v. 51, n. 6, p. 367-373, 2001. http://dx.doi.org/10.1093/occmed/51.6.367 
AMERICAN LUNG ASSOCIATION. Urban air pollution and health inequities: a workshop report. Environmental Health Perspectives, v. 109, p. 357-374, 2001. Suppl 3.

ETHIOPIA. Road Transport Authority. Cobblestone road construction in Ethiopia. 2011. Available in: www.ethiocities.com. Access in: 08 Mar. 2014.

FARIA, N. M. X.; FACCHINI, L. A.; FASSE, A. G.; TOMASI, E. Farm work, dust exposure and respiratory symptoms among farmers. Revista de Saúde Pública, v. 40, n. 5, p. 827-836, 2006. http://dx.doi.org/10.1590/S0034-89102006005000006

GILDEA, T. R.; MCCARTHY, K. Pulmonary function tests. In: Cleveland Clinic. Center for Continuing Education. 2003. Available in: http://www. clevelandclinicmeded.com/medicalpubs/diseasemanagement/pulmonary/pulmonaryfunction-testing/. Access in: 8 Mar. 2014.

GRONEBERG, D. A.; NOWAK, D.; WUSSOW, A.; FISCHER, A. Chronic cough due to occupational factors. Journal of Occupational Medicine and Toxicology, v. 1, p. 3, 2006. http://dx.doi.org/10.1186/1745-6673-1-3

HNIZDO, E.; VALLYATHAN, V. Chronic obstructive pulmonary disease due to occupational exposure to silica dust: a review of epidemiological and pathological evidence. Occupational \& Environmental Medicine, v. 60, p. 237-243, 2003. http://dx.doi.org/10.1136/oem.60.4.237

JENNY, M.; BATTIG, K.; HORISBERGER, B.; HAVES, L.; GRANDJEAN, E. Industrial medicine investigation in cement factories. Schweizerische Medizinische Wochenschrift, v. 60, n. 25, p. 705-710, 1960.

LAURENT, O.; BARD, D.; FILLEUL, L.; SEGALA, C. Effect of socioeconomic status on the relationship between atmospheric pollution and mortality. Journal of Epidemiology and Community Health, v. 61, n. 8, p. 665-675, 2007. http://dx.doi.org/10.1136/jech.2006.053611

MWAiSElAGE, J.; BRÅTVEIT, M.; MOEN, B.; MASHALlA, T. Cement dust exposure and ventilatory function impairment: an exposure-response study. Journal of Occupational and Environmental Medicine, v. 46, n. 7, p. 658-667, 2004.

NATIONAL INSTITUTE FOR OCCUPACIONAL SAFETY AND HEALTH - NIOSH (United States). Centers for Disease Control and Prevention. Spirometry quality assurance: common errors and their impact on test results. DHHS (NIOSH) Publication n. 2012-116. Available in: http://www.cdc.gov/niosh/docs/2012-116/. Access in: 08 Mar. 2014.

NOOR, H.; YAP, C. L.; ZOLKEPLI, O.; FARIDAH, M. Effect of exposure to dust on lung function of cement factory workers. Med J Malaysia, v. 55, p. 51-57, 2000.

NYBERG, F.; PERSHAGEN, G. Epidemiological studies on the health effects of ambient particulate air pollution. Scandinavian Journal of Work, Environment and Health, v. 26, p. 49-89, 2000. Suppl 1.

O'NEILL, M. S.; BELL, M. L.; RANJIT, N.; CIFUENTES, L. A.; LOOMIS, D.; GOUVEIA, N. et al. Air pollution and mortality in Latin America: the role of education. Epidemiology, v. 19, n. 6, p. 810-819, 2008. http://dx.doi.org/10.1097/ EDE.0b013e3181816528 
POPE, C. A.; BATES, D. V.; RAIZENNE, M. E. Health effects of particulate air pollution: time for reassessment? Environmental health perspectives, v. 103, n. 5, p. 472-480, 1995.

PRÜSS-ÜSTÜN, A.; CORVALÁN, C. Preventing disease through health environments. Towards an estimate of the environmental burden of disease. Geneva: WHO, 2006.

SALVI, S. S.; BARNES, P. J. Chronic obstructive pulmonary disease in non-smokers. The Lancet, v. 374, p. 733-743, 2009.

SCHENKER, M. B.; FARRAR, J. A.; MITCHELL, D. C.; GREEN, R. S.; SAMUELS, S. J.; LAWSON, R. J. et al. Agricultural dust exposure and respiratory symptoms among California farm operators. Journal of Occupational and Environmental Medicine, v. 47, n. 11, p. 1157-1166, 2005. http://dx.doi.org/ 10.1097/01.jom.0000181174.02282.0c

WORLD HEALTH ORGANIZATION - WHO. Hazard prevention and control in the work environment: Airborne dust. WHO, 1999. Available in: http://www.who.int/occupational_health/publications/airdust/en/. Access in: 08 Mar. 2014.

YANG, C. Y.; HUANG, C. C.; CHIU, H. F.; CHIU, J. F.; LAN, S. J.; KO, Y. C. Effects of occupational dust exposure on the respiratory health of Portland cement workers. Journal of Toxicology and Environmental Health, v. 49, p. 581-588, 1996. http://dx.doi.org/10.1080/009841096160637 


Ambiente \& Água - An Interdisciplinary Journal of Applied Science
ISSN 1980-993X - doi:10.4136/1980-993X
www.ambi-agua.net
E-mail: ambi-agua@agro.unitau.br

\title{
Association between maternal exposure to particulate matter and premature birth
}

\author{
doi: 10.4136/ambi-agua.1262
}

Received: 19 Dec. 2013; Accepted: 08 Mar. 2014

\section{Thaiza Agostini Córdoba de Lima; Luiz Fernando Costa Nascimento*; Andréa Paula Peneluppi de Medeiros; Veridiana de Paula Santos}

\author{
Universidade de Taubaté - Taubaté, SP, Brasil \\ Departamento de Medicina \\ *Autor correspondente: e-mail: luiz.nascimento@unitau.com.br, \\ thaiza_lima2@hotmail.com, apeneluppi@uol.com.br, \\ vevedepaula@hotmail.com
}

\begin{abstract}
The objective of this time-series study carried out in São José dos Campos, a southeastern Brazilian city, between 01.01.2005 and 31.12.2009, was to estimate the role of maternal exposure to air pollutants and preterm births. Preterm newborns of mothers aged between 18 and 34 years, with at least eight years of schooling, singleton pregnancies and whose delivery was vaginal were included in the study. Logistic regression was used to estimate the role of particulate matter, ozone and sulfur dioxide on preterm delivery with lags of zero up to 30 days. Exposure to particulate matter was associated significantly with preterm newborns in lags of 0,1 and 3 days; but no association was found between cumulative maternal exposure in lags of 7, 15 and 30 days and the outcome. Maternal exposure to particulate matter therefore has an acute effect on preterm births in a medium-sized Brazilian town.
\end{abstract}

Keywords: air pollutants, preterm birth, logistic regression, particulate matter, air pollution.

\section{Associação entre a exposição materna ao material particulado e parto prematuro}

\section{RESUMO}

O objetivo deste estudo de séries temporais desenvolvido em São José dos Campos, localizada sudeste do Brasil, entre 01.01.2005 e 31.12.2009, foi estimar o papel da exposição materna aos poluentes do ar e partos prematuros. Recém-nascidos prematuros de mães com idade entre 18 e 34 anos, com pelo menos oito anos de escolaridade, gestações únicas e cujo parto foi vaginal foram incluídos no estudo. A regressão logística foi utilizada para estimar o papel da exposição ao material particulado, ozônio e dióxido de enxofre em trabalho de parto prematuro com defasagens de zero até 30 dias. Exposição ao material particulado esteve associada significativamente com partos prematuros em lag 0,1 e 3 , mas não houve associação entre a exposição materna acumulada sete, 15 e 30 dias antes do parto e o desfecho. Assim, a exposição materna ao material particulado tem um efeito agudo em recém-nascidos prematuros em uma cidade de brasileira de porte médio.

Palavras-chave: poluentes do ar, parto prematuro, regressão logística, material particulado, poluição do ar. 


\section{INTRODUCTION}

Preterm is, according to the International Classification of Diseases (WHO, 1993), a birth that occurs at less than 37 weeks gestational age and is a serious problem for women during pregnancy. These infants have a high risk of illness and death due to their incomplete fetal development and increased susceptibility to infections (Vaast et al., 2004). The etiology of preterm birth is complex and involves several factors including environmental factors. (Nascimento, 2001; Tucker and McGuire, 2005).

Data from the Brazilian Ministry of Health show that the occurrence of preterm births in Brazil grew $27 \%$ between 1997 and 2006, representing an increase of 5.3 to $6.7 \%$ of total births in the country. However, it is not only in Brazil that the table of prematurity increase is showing gradual increases, but also in almost all countries of the world, where some experts believe that an epidemiological perinatal transition is occurring (Silveira et al., 2008).

The main air pollutants are particulate matter $\left(\mathrm{PM}_{10}\right)$, ozone $\left(\mathrm{O}_{3}\right)$ and sulfur dioxide $\left(\mathrm{SO}_{2}\right)$. Particulate material is a mixture of liquid and solid particles suspended in the air, which vary in size (most studied are the particles smaller than 10 microns in aerodynamic diameter - $\mathrm{PM}_{10}$ ) and are emitted via mechanical dispersions of organic material and via uncontrolled combustion. Ozone, a gaseous material with high oxidative and cytotoxic potential, is a secondary pollutant; and sulfur dioxide, also gaseous, is the result of combustion of fossil elements (coal and oil) (Bascom et al., 1996).

Association between maternal exposure to air pollutants and preterm delivery has been demonstrated in several articles (Zhao et al., 2011; Sagiv et al., 2005; Xu et al., 1995; Bobak, 2000; Ritz et al., 2000; Ritz et al., 2007; Leem et al., 2006; Sram et al., 2005; Lacasana et al., 2005; Wilhelm and Ritz, 2005; Huynh et al., 2006; Bell at al., 2007; Steb et al., 2012). These studies have implicated $\mathrm{PM}_{10}, \mathrm{SO}_{2}$, total suspended particles (TSP), $\mathrm{NO}_{2}, \mathrm{O}_{3}$ and $\mathrm{CO}$, especially when analyzed at the beginning or end of pregnancy, in quarters, or even a few days before delivery. A recent review shows studies with associations of exposures to these pollutants and preterm birth and also low birth weight, especially to particulate matter (Kannan et al., 2007).

Given the prevalence of preterm birth in Brazil (approximately 7.0\%) and in the state of São Paulo (about 8.5\%) (Brazil, 2012) and given that the newborn preterm contributed to just over $40 \%$ of deaths in children under 1 year of age in Brazil and to about $44 \%$ of deaths in the state of São Paulo (Brazil, 2012), the aim of this study was to estimate the role of maternal exposure to particulate matter and preterm delivery in São José dos Campos, SP.

\section{MATERIAL AND METHODS}

This is a time-series ecological study on the exposure of pregnant women to air pollutants and preterm births that are consolidated in the Brazilian Information System on Live Births Ministry of Health (SINASC). SINASC was the source of the records.

The study period was from January 1, 2005 to December 31, 2009. The study was conducted in the municipality of São José dos Campos, a city in southeastern Brazil; it is considered medium-sized, and its geographical coordinates are $23^{\circ} 10^{\prime} \mathrm{S}$ and $45^{\circ} 52^{\prime} \mathrm{W}$, being located $600 \mathrm{~m}$ above the sea with tropical humid climate. It has an important industrial park and had an estimated population of just over 600,000 inhabitants in 2009. It is located between São Paulo and Rio de Janeiro, the two largest cities in Brazil, and is crossed by Dutra Highway that carries heavy bus and truck traffic, with a daily flow of approximately 130,000 vehicles.

This database was analyzed in two ways: unadjusted analysis: all preterm infants, without any selection or exclusion criteria; and adjusted analysis, with only those premature 
births by mothers between 18 and 34 years old, resulting from a single pregnancy, whose delivery was vaginal and whose mothers had at least eight years of schooling in order to minimize the effects of these potential confounders. This approach was used in another study (Nascimento and Moreira, 2009).

The Live Birth Certificate (DNV) is an official document required for the civil registration of a child; it contains various information regarding the mother and newborn. We excluded information on premature birth where weight was greater than 2800 grams under the assumption that there was an error or in the evaluation of weight or in the gestational age. Gestational age is categorized into classes: from 22 to 27 weeks of gestation, from 28 to 32 weeks of gestation and from 33 to 36 weeks of gestation.

We selected the data of the concentrations of pollutants: particulate matter under 10 micra in aerodynamic diameter $\left(\mathrm{PM}_{10}\right)$, sulfur dioxide $\left(\mathrm{SO}_{2}\right)$, in its daily means, and ozone $\left(\mathrm{O}_{3}\right)$ in its daily 8-hour maximum, as obtained from Agency of Environmental Sanitation Technology (Cetesb), which has a metering station in São José dos Campos. The Beta monitor technique was used to evaluate the $\mathrm{PM}_{10}$; the coulometry technique was used to evaluate $\mathrm{SO}_{2}$; and chemiluminescence was used for $\mathrm{O}_{3}$. Air pollutants were quantified in $\mu \mathrm{g} \mathrm{m}^{-3}$. Ozone, $\mathrm{PM}_{10}$ and $\mathrm{SO}_{2}$ were analyzed separately (unipollutant model) and jointly (multipollutant model) and their concentrations were analyzed continuously.

We made a 0 to 7 day lag model to study the effects of exposure to air pollutants, because may be a lag for the effects of maternal exposure to pollutants and the outcome. The role of cumulative effects of maternal exposure and preterm birth was analyzed considering lags of seven, 15 and 30 days between exposure and birth.

We used the logistic regression model to estimate the risk for the occurrence of at least one preterm delivery because of maternal exposure to air pollutants. The coefficients obtained through logistic regression can be used to calculate the chances of preterm birth as well as the percentage increase with $20 \mu \mathrm{g} \mathrm{m}^{-3}$ in $\mathrm{PM}_{10}$ concentration increase. We presented in tabular form the values of OR with confidence intervals of $95 \%$ for each pollutant in the multipollutant model and adjusted analysis, with 0-7 day lags and also for the cumulative effects at seven, 15 and 30 days. For unipollutant models, both in the unadjusted and in the adjusted approach, and for the multipollutant model according to the crude analysis, the significant values found $(\mathrm{p}<0.05)$ were reported in the results section.

The software used for this analysis was the SPSS v17.

\section{RESULTS}

Forty-four thousand nine hundred ninety-four children were born during the study period (2005-2009) and 3799 newborn (8.4\%) were preterm births; 769 infants $(20.2 \%$ of all preterm births) met the inclusion criteria. The descriptive analysis with the mean values, minimum, maximum and standard deviation of the pollutants are shown in Table 1.

Table1. Descriptive analysis of air pollutants $\mathrm{SO}_{2}, \mathrm{PM}_{10}$ e $\mathrm{O}_{3}$, São José dos Campos, Brazil, 2005 to 2009.

\begin{tabular}{c|ccc}
\hline POLLUTANT & MEAN (SD) & Min $\left(\boldsymbol{\mu} \mathbf{g ~ m}^{-\mathbf{3}}\right)$ & Max $\left(\boldsymbol{\mu} \mathbf{g ~ m}^{-\mathbf{3}}\right)$ \\
\hline $\mathrm{SO}_{2}$ & $3.16(1.97)$ & 1 & 17 \\
$\mathrm{PM}_{10}$ & $23.93(12.21)$ & 6 & 100 \\
$0_{3}$ & $80.28(32.29)$ & 5 & 209 \\
\hline
\end{tabular}

SD: standard deviation; Min: minimum values; Max (maximum values). 
The distribution of concentrations of pollutants over the period identified that ozone did not show a seasonal behavior, unlike $\mathrm{SO}_{2}$ and $\mathrm{PM}_{10}$, whose highest concentrations occurred in the winter months. The distribution of preterm births by month of birth appears to show a seasonal pattern, with higher values in July and August, months with higher concentrations of pollutants (data not shown). However, this distribution does not seem to repeat seasonally, when only the cases that met the inclusion criteria were inserted.

\subsection{Statistical results}

\subsubsection{Unipollutant model}

The coefficients obtained from the logistic regression, analyzing maternal exposure to $\mathrm{PM}_{10}$, showed a significant result in the crude analysis in lag 4 $(\mathrm{OR}=1.01495 \% \mathrm{CI} 1.001$ - 1.027), and exposure of pregnant women to ozone was associated with preterm delivery in the lag 1 of exposure, with $\mathrm{OR}=1.005$ (95\% CI 1.000 to 1.010); exposure to sulfur dioxide was not associated with preterm delivery in any form of analysis. Exposure to $\mathrm{PM}_{10}$, alone, was not statistically significant in the lags of seven, 15 and 30 days before delivery.

\subsubsection{Multipollutant model}

In the unadjusted analysis of all preterm infants, there was no evidence of an association between exposure to pollutants and preterm birth. In the adjusted analysis, i.e., that performed with newborns who fulfilled the inclusion criteria, only acute exposure to $\mathrm{PM}_{10}$ at lag 0 $(\mathrm{OR}=1.01195 \% \mathrm{CI} 1.001$ to 1.021$)$, lag $1(\mathrm{OR}=1.01395 \% \mathrm{CI} 1.003$ to 1.023$)$ and lag 3 $(\mathrm{OR}=1.01195 \%$ CI 1.001 to 1.022$)$ were statistically significant (Table 2$)$. In the analysis of cumulative effects, ozone showed paradoxical protective behavior with exposure at 7 and 15 days before delivery.

Table 2. Odds Ratio coefficients (OR) and respective $95 \%$ confidence intervals $(95 \% \mathrm{CI})$ to preterm birth according to air pollutants (lag 0 to lag 7), São José dos Campos, Brazil, 2005-2009.

\begin{tabular}{c|ccc}
\hline $\mathbf{L A G}$ & $\mathbf{S O}_{\mathbf{2}} \mathbf{O R}(\mathbf{9 5 \%} \mathbf{C I})$ & $\mathbf{P M}_{\mathbf{1 0}} \mathbf{O R}(\mathbf{9 5 \%} \mathbf{C I})$ & $\mathbf{O}_{\mathbf{3}} \mathbf{O R}(\mathbf{9 5 \%} \mathbf{C I})$ \\
\hline $\mathbf{0}$ & $0.978(0.920-1.039)$ & $\mathbf{1 . 0 1 1}(\mathbf{1 . 0 0 1 - 1 . 0 2 1}) \#$ & $0.998(0.995-1.002)$ \\
$\mathbf{1}$ & $0.995(0.937-1.057)$ & $\mathbf{1 . 0 1 3}(\mathbf{1 . 0 0 3 - 1 . 0 2 3}) \#$ & $0.998(0.995-1.002)$ \\
$\mathbf{2}$ & $1.036(0.976-1.101)$ & $1.006(0.996-1.017)$ & $1.001(0.997-1.005)$ \\
$\mathbf{3}$ & $1.017(0.956-1.081)$ & $\mathbf{1 . 0 1 1}(\mathbf{1 . 0 0 1 - 1 . 0 2 2}) \#$ & $0.997(0.993-1.000)$ \\
$\mathbf{4}$ & $1.002(0.942-1.065)$ & $1.003(0.992-1.013)$ & $0.999(0.996-1.003)$ \\
$\mathbf{5}$ & $1.055(0.992-1.122)$ & $1.001(0.990-1.011)$ & $0.996(0.993-1.000)$ \\
$\mathbf{6}$ & $0.987(0.926-1.051)$ & $1.006(0.995-1.016)$ & $0.997(0.993-1.001)$ \\
$\mathbf{7}$ & $1.024(0.963-1.090)$ & $1.003(0.993-1.013)$ & $0.999(0.996-1.003)$ \\
\hline
\end{tabular}

$\# \mathrm{p}<0.05$.

Exposure to other pollutants was not associated with preterm delivery (Table 3). It was possible to estimate the chances of premature births in this time series by applying the results obtained by using logistic regression. When computed, the resulting mean value of this analysis for 0 lag was $33.6 \%(24.7 \%-54.4 \%)$, for the lag of 1 was $33.8 \%$ $(26.7 \%-59.7 \%)$ and for the lag of 3 was $35.5 \%$ (25.5\% - 58.0\%). The distribution of these chances has a seasonal aspect with greater chances occurring in the winter months (data not shown in figure). 
Table 3. Odds Ratio coefficients (OR) and respective $95 \%$ confidence intervals (95\% CI) for preterm birth according to air pollutants (lags 7, 15 and 30 days - cumulative effects), São José dos Campos, Brazil, 2005-2009.

\begin{tabular}{c|ccc}
\hline $\mathbf{L A G}$ & $\mathbf{S O}_{2} \mathbf{O R}(\mathbf{9 5} \% \mathbf{C I})$ & $\mathbf{P M}_{\mathbf{1 0}} \mathbf{O R}(\mathbf{9 5} \% \mathbf{C I})$ & $\mathbf{O}_{\mathbf{3}} \mathbf{O R}(\mathbf{9 5} \% \mathbf{C I})$ \\
\hline $\mathbf{7}$ & $1.002(0.989-1.016)$ & $1.001(0.999-1.003)$ & $0.999(0.998-1.000) \#$ \\
$\mathbf{1 5}$ & $1.003(0.995-1.010)$ & $1.000(0.999-1.001)$ & $0.999(0.999-1.000) \#$ \\
$\mathbf{3 0}$ & $1.001(0.977-1.006)$ & $1.000(0.999-1.001)$ & $0.999(0.998-1.001)$ \\
\hline
\end{tabular}

$\# \mathrm{p}<0.05$

With an increase in the concentration of $\mathrm{PM}_{10}$ from 20 to $40 \mu \mathrm{g} \mathrm{m}-3$ and maintaining the concentrations of other pollutants, at the mean value of each one, the chance of occurrence of at least one premature birth increased from $30 \%$ to $38 \%$.

\section{DISCUSSION}

This study shows that exposure of pregnant women to $\mathrm{PM}_{10}$ was associated with preterm birth in the immediate days after these exposures, in a medium-sized city in southeastern Brazil. It is, to the best of our knowledge, the first study released in Brazil on the topic pollution and premature birth.

In the study site, the city of São José dos Campos, the prevalence of preterm delivery was $8.4 \%$, very close to that reported by Datasus for the state of São Paulo. Observing the distribution of preterm births according to the months in which they occurred, there seems to be a seasonal pattern when analyzed without the inclusion criteria; on the other hand, when these criteria were used, there seems to be no seasonal distribution. Perhaps the number of cases included, 769, was too small or the perhaps time series should include a larger number of years.

First, all preterm infants were analyzed, regardless of their preterm category, in unipollutant models. Isolated, exposure to $\mathrm{PM}_{10}$ showed statistically significant results, and was associated with preterm delivery when this exposure occurred four days before delivery, suggesting an acute effect of this exposure. The cumulative effects were not significant for this pollutant.

Exposure to $\mathrm{O}_{3}$ showed significant results only in the crude analysis. It was more important in the genesis of preterm infants when delivery came a day after exposure. $\mathrm{SO}_{2}$ was not statistically significant for all types of analysis.

When the pollutants were analyzed in a multipollutant model, in the crude analysis, without considering the inclusion criteria, it was not possible to identify an association between exposure and outcome. When the inclusion criteria was considered, only the $\mathrm{PM}_{10}$ was associated with preterm delivery in lags of 0,1 and 3; exposure to accumulated data of this pollutant was not associated with preterm birth. On the other hand, ozone presented a paradoxical behavior when the delivery occurred 7 and 15 days after exposure. Alves et al. (2010) reported this pattern, in a study on exposure to air pollutants and cardiorespiratory diseases.

Exposure to particulate matter has also been associated with premature newborn when maternal exposure occurred six weeks before delivery (Sagiv et al., 2005). To evaluate the role of exposure to $\mathrm{PM}_{10}$ and premature delivery, these authors used Poisson regression and, examining lags, the $\mathrm{PM}_{10}$ was significant in lags of 2 and 5 , results quite similar to the findings in our study. $\mathrm{Xu}$ et al. (1995) identified $\mathrm{SO}_{2}$ and TPS, being $\mathrm{PM}_{10}$ part of the TSP, as associated with the premature newborn at lags of $1,3,5$ and 7 , results very similar to those 
found in this study at São José dos Campos, citing that the mean values of $\mathrm{SO}_{2}$ were approximately 30 times higher than those found in the study presented here.

A study carried out in China (Zhao et al., 2011) showed the role of exposure to $\mathrm{PM}_{10}$ in premature births also in the 0 lag when this pollutant was analyzed together with the $\mathrm{SO}_{2}$ and $\mathrm{NO}_{2}$. In this Chinese study, the mean concentrations of $\mathrm{SO}_{2}$ and $\mathrm{PM}_{10}$ were $82.5 \mu \mathrm{g} \mathrm{m}^{-3}$ and $51.7 \mu \mathrm{g} \mathrm{m}^{-3}$ respectively, well above the values found in this Brazilian study.

It was also not possible to identify the association of prematurity with exposure to $\mathrm{SO}_{2}$. Probably the levels of this pollutant in São José dos Campos did not reach sufficient concentrations to cause adverse effects in pregnancy, since there are other studies that identified an association between the pollutant and preterm delivery (Zhao et al., 2011; Xu et al., 1995; Bobak, 2000).

Bobak (2000) concluded that the effects of pollutants were higher when the exposure occurred in the first trimester of pregnancy. Our study showed an acute effect of exposure to pollutants. The birth occurs the same day or no later than three days after exposure. These results indicate that there must be a mechanism for the effect of cumulative exposure and acute exposure. Possible causes would be cardiovascular mechanisms of oxidative stress, inflammation, coagulation and hemodynamic responses (Kannan et al., 2007).

Ritz et al. (2000) found an association with $\mathrm{PM}_{10}$ and $\mathrm{CO}$, when exposure occurred in the first quarter or in the end of pregnancy. These findings were confirmed in another study, also in California, with respect to $\mathrm{CO}$ and $\mathrm{PM}_{2.5}$ (Ritz et al., 2007). Maternal exposure in the third trimester of pregnancy was also associated with preterm delivery in Korea (Leem et al., 2006). Early and late exposures to $\mathrm{CO}$, total suspended particulates $\left(\mathrm{PM}_{10}, \mathrm{PM}_{2.5}\right), \mathrm{SO}_{2}$, and $\mathrm{NO}_{2}$ were significantly associated with the genesis of preterm birth in several papers (Sram et al., 2005; Lacasana et al., 2005; Wilhelm and Ritz, 2005; Huynh et al., 2006).

It should be noted that the association between air pollution and prematurity was found in polluted areas such as Los Angeles (Huynh et al., 2006) but also other areas with low levels of urban pollution (Bell et al., 2007).

Given the values of the concentrations of air pollutants in accordance with the air quality index, provided by Cetesb, and given the maximum values of the pollutants found in the present study, it is observed that $\mathrm{SO}_{2}$ always receives a rating of "good." The $\mathrm{PM}_{10}$ concentrations showed that the air quality became regular in $4.1 \%$ of days. The $\mathrm{O}_{3}$ concentrations showed that the air quality became regular in $44.8 \%$ and poor in $1.4 \%$ of days (Available at: http://sistemasinter.cetesb.sp.gov.br/Air/ar_indice_padroes.asp. Accessed on: April 10, 2012).

The aim of this study was not to identify which biological mechanism links exposure to air pollutants and preterm birth, but to present possible associations between exposure to air pollutants and preterm delivery. Although exposure to air pollutants has been identified as a risk factor for preterm birth, the biological mechanisms that lead to preterm birth and the critical period of vulnerability are not well understood; this critical period, or window as it is known, could be in early (first quarter) or late pregnancy (last quarter) as seen above (Bobak, 2000; Ritz et al., 2000;. Ritz et al., 2007; Leem et al., 2006).

Observing these results, several potential mechanisms can be considered. One possible explanation for the acute effect of air pollution on preterm birth suggests that air pollutants can generate inflammatory mediators in the lungs that influence the vascular circulatory function (Brook et al., 2003). Thus, inflammation has also been associated with premature birth and may be associated with inadequate placental perfusion (Knotternus et al., 1990; Zondervan et al., 1987)

In trying to understand the cumulative effects of pollutants, it can be speculated that chronic exposure to high levels of pollution can influence the functions of the placenta. The 
exposure to pollutants increases the viscosity of the blood and plasma fibrinogen, thereby decreasing the organ perfusion (Seaton et al., 1999).

Another explanation for the cumulative effects caused by exposure to pollutants during pregnancy points to maternal infections. Although air pollution does not directly cause infections, exposure to specific pollutants can impair immune function, which can increase susceptibility to infections (Hertz-Picciotto et al., 2002; Lee et al., 2011) and some infections are risk factors for preterm delivery (Silveira et al., 2008).

Possible limitations of the study are the analysis of three pollutants $\mathrm{O}_{3}, \mathrm{SO}_{2}$ and $\mathrm{PM}_{10}$, and not the impact of exposure to others pollutants such as $\mathrm{CO}$ and $\mathrm{NO}_{2}$, because the Cetesb measuring station does not quantify them. Another limitation could be that the data on air pollution were detected at a fixed monitoring site and, as such, do not represent accurately the level of individual exposure to pollutants, and so could underestimate the impact of pollution on health. Gestational age is difficult to measure accurately and so it may have been incorrectly estimated. Also, this information is not covered in detail, such as in weeks, for example. In the SINASC, the source of our data, this variable is presented as categorized. For this reason, it was not possible to perform analysis in quarters because there was no certainty in determining the true duration of pregnancy; it was therefore impossible to estimate the role of exposure to pollutants in early pregnancy.

Besides the above mentioned, it was not possible to obtain information on comorbidities, such as hypertension in pregnancy, noting that exposure to $\mathrm{PM}_{10}$ is associated with hospitalization for hypertension in medium-sized cities (Nascimento et al., 2012), because these data are not available on the website of Datasus nor is data on maternal habits, such as smoking.

It is also assumed that pregnant women moved freely around the city, constantly exposing themselves to pollutants, which disregards the fact that the pregnant woman is more sedentary at the end of pregnancy.

Despite the limitations of the work, it is noteworthy that the study covered a period of five years; during this period there were enough premature births to obtain a statistical result, minimizing potential fluctuations.

\section{CONCLUSIONS}

This work identified that maternal exposure to air pollutants, especially to particulate matter, can trigger premature births, which can occur both on the day that the mother was exposed to particulate matter and up to three days after the exposure. The importance of reducing premature birth is evident, as prematurity is responsible for much neonatal mortality and neonatal morbidity. The control of air pollution is among the measures that may be employed to bring about such a reduction.

\section{REFERENCES}

ALVES, C. A.; SCOTTO, M.; FREITAS, M. C. Air pollution and emergency admissions for cardiorespiratory diseases in Lisbon. Química Nova, v. 33, n 2, p. 337-344, 2010. http://dx.doi.org/10.1590/S0100-40422010000200020

BASCOM, R.; BROMBERG, P. A.; COSTA, D. A. et al. State of the art. Health effects Of outdoor pollution. American Journal of Respiratory and Critical Care Medicine, v. 153, n. 1, p. 3-50, 1996. 
BELL, M. L.; EBISU, K.; BELANGER, K. Ambient air pollution and low birth weight in Connecticut and Massachusetts. Environmental Health Perspectives, v. 115, p. 1118 - 1124, 2007. http://dx.doi.org/10.1289/ehp.9759

BOBAK, M. Outdoor air pollution, low birth weight, and prematurity. Environmental Health Perspectives, v. 108, p. 173-176, 2000.

BRAZIL. Ministry of Health. Departamento de Informática do SUS. Datasus. Available: http://tabnet.datasus.gov.br/cgi/tabcgi.exe?sinasc/cnv/nvuf.def. Access: May 102012.

BROOK, R. D.; BROOK, J. R.; URCH, B.; VINCENT, R.; RAJAGOPALAN, S. Inhalation much air pollution particles and ozone cause acute arterial vasoconstriction in healthy adults. Circulation, v. 105, p. 1534-1536, 2003.

HERTZ-PICCIOTTO I; DOSTÁL M; DEJMEK J; SELEVAN SG; WEGIENKA G; GOMEZ-CAMINERO A. et al. Air pollution and distributions of lymphocyte immunophenotypes in cord and maternal blood at delivery. Epidemiology, v. 13, n.2, p.172-183, 2002.

HUYNH, M.; WOODRUFF, T. J.; PARKER, J. D.; SCHOENDORF, K. C. Relationships between air pollution and preterm birth in California. Paediatric and Perinatatal Epidemiology, v. 20, p. 454-461, 2006. http://dx.doi.org/10.1111/j.1365-3016.2006. 00759.x

KANNAN, S.; MISRA, D. P.; DVONCH, J. T.; KRISHNAKUMAR, A. Exposures to airborne particulate matter and adverse perinatal outcomes: a biological plausible mechanistic framework for exploring potential. Ciência \& Saúde Coletiva, v. 12, n. 6, 2007. http://dx.doi.org/10.1590/S1413-81232007000600020

KNOTTERNUS, J. A.; DELGADO, L. R.; KNIPSCHILD, P. G.; ESSED, G. G.; SMITS, F. Haematological parameters and pregnancy. A prospective study in the third quarter. Journal of Clinical Epidemiology, v. 43, p. 461-466, 1990.

LACASANA, M.; ESPLUGUES, A.; BALLESTER, F. Exposure to ambient air pollution and health effects on prenatal and early childhood. European Journal of Epidemiology, v. 20,p p. 183 - 199, 2005. http://dx.doi.org/10.1007/s10654-004-3005-9

LEE, P. C.; TALBOT, E. O.; ROBERTS, J. M.; CATOV, J. M.; SHARMA, R. K.; RITZ, B. Particulate air pollution exposure and C-reactive Protein during early pregnancy. Epidemiology, v. 22, p. 524-531, 2011. http://dx.doi.org/10.1097/EDE.0b013e31821c6c58

LEEM, J. H.; KAPLAN, B. M.; SHIM, Y. K.; POHL, H. R.; GOTWAY, C. A.; BULLARD, S. M. et al. Exposures to air Pollutants during pregnancy and preterm delivery. Environmental Health Perspectives, v. 114, n. 6, p. 905-910, 2006. http://dx.doi.org/10.1289/ehp.8733

NASCIMENTO, L. F. C. Epidemiology of preterm deliveries in Southeast Brasil: a hospitalbased study. Revista brasileira de Saúde materno infantil, v. 1, p. 263-268, 2001. http://dx.doi.org/10.1590/S1519-38292001000300007

NASCIMENTO, L. F. C.; FRANCISCO, J. B.; PATTO, M. B. R.; ANTUNES, A. M. Particulate matter and hospital admission due to arterial hypertension in a Brazilian medium-size city. Cadernos de Saúde Pública, v. 28, n. 7, p. 1319-1324, 2012. http://dx.doi.org/10.1590/S0102-311X2012000700010 
NASCIMENTO, L. F. C.; MOREIRA, D. A. Are environmental pollutants risk factors for low birth weight? Cadernos de Saúde Pública, v. 25, n 8, p. 1791-1796, 2009. http://dx.doi.org/10.1590/S0102-311X2009000800015

RITZ, B.; WILHELM, M.; HOGGATT, K. J.; GHOSH, J. K. C. Ambient air pollution and preterm birth in the UCLA environment and pregnancy outcomes study at the University of California, Los Angeles. American Journal of Epidemiology, v. 166, n. 9, p. 1045-1052, 2007. http://dx.doi.org/10.1093/aje/kwm181

RITZ, B.; YU, F.; CHAPA, G.; FRUIN, S. Effect of air pollution on preterm birth among children born in Southern California between 1989 and 1993. Epidemiology, v. 11, p. 502-511, 2000 .

SAGIV, S. K.; MENDOLA, P.; LOOMIS, D.; HERRING, A. H.; NEAS, L. M.; SAVITZ, D. A. et al. A time series analysis of air pollution and preterm birth in Pennsylvania, 1997-2001. Environmental Health Perspectives, v. 113, n. 5, p. 602-606, 2005. http://dx.doi.org/10.1289/ehp.7646

SEATON, A.; SOUTAR, A.; CRAWFORD, V.; ELTON, R.; MCNERLAN, S.; CHERRIE, J. et al. Particulate air pollution and the blood. Thorax, v. 54, n.11, p. 1027- 1032, 1999. http://dx.doi.org/10.1136/thx.54.11.1027

SILVEIRA, M. F.; SANTOS, I. S.; BARROS, A. J. D.; MATIJASEVICH, A.; BARROS, F. C.; VICTORA, C. G. Increase in preterm births in Brazil: review of population-based studies. Revista de Saúde Pública, v. 42, n. 5, p. 957-964, 2008. http://dx.doi.org/10.1590/S0034-89102008000500023

SRAM, R. J.; BINKOVA, B.; DEJMEK, J.; BOBAK, M. Ambient air pollution and pregnancy outcomes: a literature review. Environmental Health Perspectives, v. 113, p. 375 - 382, 2005. http://dx.doi.org/10.1289/ehp.6362

STEB, D. M.; CHEN, L.; ESHOUL, M.; JUDEK, S. Ambiente air pollution, birth weight and preterm birth: a systematic review and meta-analysis. Environmental Research, v. 117, p. 100 - 101, 2012. http://dx.doi.org/10.1016/j.envres.2012.05.007

TUCKER, J.; MCGUIRE, W. Epidemiology of preterm birth. British Medical Journal, v. 329, p. 675-678, 2005.

VAAST, P.; HOUFFlin-DEBARGE, V.; DERUELlE, P.; SUBTIL, D.; STORNE, L.; PUECH, F. Could the consequences of premature delivery be futher attenuated by means of new prenatal strategies? European Journal Of Obstetrics Gynecology and Reproductive Biology, v. 117, Suppl 1, p. p. 21-24, 2004. http://dx.doi.org/10.1016/j.ejogrb.2004.07.013

WORLD HEALTH ORGANIZATION. International statistical classification of diseases and related health problems. $10^{\text {th }}$ Revision. Geneva, 1993.

XU, X.; DING, H.; WANG, X. Acute effects of total suspended particles and sulfur dioxides on preterm delivery: a community-based cohort study. Archives of Environmental Health and Perspectives, v. 50, n. 6, p. 407-415, 1995. $10.1080 / 00039896.1995 .9935976$

WILHELM, M.; RITZ, B. Local variations in CO and particulate air pollution and adverse birth outcomes in Los Angeles, California, USA. Environmental Health Perspectives, v. 113, p. $1212-1221,2005$. http://dx.doi.org/10.1289/ehp.7751 
ZHAO, Q.; LIANG Z.; TAO, S.; ZHU, J.; DU, Y. Effects of air pollution on neonatal prematurity in Guangzhou of China: a time-series study. Environmental Health, v. 10, p. 2, 2011. http://dx.doi.org/10.1186/1476-069X-10-2

ZONDERVAN, H. A.; OOSTING, J.; HARDEMAN, M. R.; SMORENBERG-SCHOORL, M. E.; TREFFERS, P. E. The influence of maternal whole blood viscosity in fetal growth. European Journal Of Obstetrics Gynecology And Reproductive Biology, v. 25, p. 187-194, 1987. http://dx.doi.org/10.1016/0028-2243(87)90098-0 


Ambiente \& Água - An Interdisciplinary Journal of Applied Science
ISSN 1980-993X - doi:10.4136/1980-993X
www.ambi-agua.net
E-mail: ambi-agua@agro.unitau.br

\title{
Sweet almond (Prunus amygdalus "dulcis") seeds as a potential feedstock for Nigerian Biodiesel Automotive Project
}

\author{
doi: 10.4136/ambi-agua.1272 \\ Received: 03 Jan. 2014; Accepted: 10 Mar 2014 \\ Solomon Giwa $^{1 *}$; Clement Ogunbona ${ }^{2}$ \\ ${ }^{1}$ Olabisi Onabanjo University, College of Engineering and Environmental Studies - Ifo, Ogun State, Nigeria \\ Department of Agricultural and Mechanical Engineering, Ibogun Campus \\ ${ }^{2}$ Bells University of Technology, College of Natural Sciences - Ota, Ogun State, Nigeria \\ Chemical Science Laboratory \\ *Corresponding author: e-mail: sologiwa2002@yahoo.com, \\ ibido2001@yahoo.com
}

\begin{abstract}
This work presents sweet almond (Prunus amygdalus "dulcis") seed oil (SASO) as a non-conventional feedstock for the preparation of biodiesel in Nigeria, rather than the traditional oils of palm, groundnut and palm kernel. SASO was extracted via the solvent method, pretreated to reduce the acid value, and transesterified using methanol (solvent) and sodium hydroxide (catalyst). The oil content and acid value of SASO were $51.45 \pm 3.92 \%$ and $1.07 \mathrm{mg} \mathrm{KOH} / \mathrm{g}$, respectively. The fatty acid composition of SASO reveals the predominance of oleic acid (69.7\%), linoleic acid (18.2\%) and palmitic acid (9.3\%). Specific fuel properties of sweet almond oil methyl esters (SAOME) were determined using standard test methods and were found to satisfy both EN 14214 and ASTM D6751 biodiesel standards; the cold flow properties were particularly outstanding (cloud point; $-3^{\circ} \mathrm{C}$ and pour point; $-9^{\circ} \mathrm{C}$ ). SASO appears to offer great promise as a potential feedstock for biodiesel production in Nigeria.
\end{abstract}

Keywords: sweet almond seeds, fuel properties, transesterification, oil, biodiesel, Nigeria.

\section{Sementes de amêndoa doce (Prunus amygdalus "dulcis") como uma matéria-prima potencial para o Projeto Nigeriano de Biodiesel Automotive}

\section{RESUMO}

Este trabalho apresenta o óleo de semente (SASO) de amêndoa doce (Prunus Amygdalus "dulcis") como matéria-prima não convencional para a preparação de biodiesel na Nigéria em adição aos óleos tradicionais de amendoim e dendê. O SASO foi extraído usando o método de solvente, pré-tratado para reduzir o índice de acidez e transesterificado usando metanol (solvente) e hidróxido de sódio (catalisador). O teor de óleo e o valor ácido do SASO foram $51,45 \pm 3,92 \%$ e $1,07 \mathrm{mg}$ de $\mathrm{KOH} / \mathrm{g}$, respectivamente. A composição de ácidos graxos do SASO revela a predominância de ácido oleico $(69,7 \%)$, ácido linoleico $(18,2 \%)$ e ácido palmítico $(9,3 \%)$. As propriedades combustíveis específicas de ésteres metílicos do óleo de amêndoa doce (SAOME) foram determinadas utilizando métodos de ensaio normalizados e satisfizeram tanto as normas de biodiesel EN 14214 e ASTM D6751, especialmente as 
propriedades de fluxo a frio foram excelentes (ponto de nuvem; $-3^{\circ} \mathrm{C}$ e ponto de fluidez; $-9^{\circ} \mathrm{C}$ ). Conclusivamente, o SASO parece ser uma matéria-prima potencial para produção de biodiesel na Nigéria.

Palavra-chave: sementes de amêndoa doce, propriedades de combustível, transesterificação, petróleo, biodiesel, Nigéria.

\section{INTRODUCTION}

The continual use of fossil fuel has negatively impacted our society, leading to numerous global environmental problems such as the greenhouse effect, global climate change, acidification and ozone depletion. These impacts are caused by rising $\mathrm{CO}_{2}$ levels and other products of fossil fuel combustion (Ishola et al., 2013). They have affected rainfall patterns resulting in excessive rainfall and drought. Biomass-derived fuel (biofuel) has emerged as the only liquid fuel that can be substituted for fossil liquid fuels. Through biomass, fossil fuels (gasoline, diesel and liquefied petroleum gas) have been successfully partially replaced by biofuels (bioethanol, biodiesel and biogas).

Energy security is one of the main reasons why most countries engage in biofuel programs. Nigeria, a major petroleum producing and exporting nation is also embarking on biofuel projects in order to join the league of nations in benefitting from the advantages gained by the use of biofuels (Ishola et al., 2013). These projects involve the blending of up to $10 \%$ bioethanol with gasoline to achieve an E10 blend and a $20 \%$ blend of biodiesel with petro-diesel to make a B20 blend (Ishola et al., 2013). Nigeria desires to use the petroleum sector to improve the agriculture sector by investing in biofuels.

Biodiesel is a type of biofuel which can be used as a substitute for fossil-derived diesel. The use of conventional oils such as palm oil, sunflower oil, rape seed oil and soybean oil for biodiesel production is prevalent (Balat and Balat, 2008; Demirbas, 2007) and this has often strained food uses, price, production and availability of these oils (Rashid et al., 2008). This has spurred researchers to make use of inedible oils, waste cooking oils and lesser known oils in the production of biodiesel (Balat and Balat, 2008; Ofoefule et al., 2013; Bamgboye and Oniya, 2012).

Oils of some oil-bearing plants have been investigated as potential feedstocks for biodiesel production in Nigeria. These include; palm oil (Izah and Ohimain, 2013), palm kernel oil (Alamu et al., 2008), egusi melon oil (Giwa, et al., 2010), coconut oil (Alamu et al. 2010), tigernut (Ofoefule et al., 2013), African mango nut oil (Bello et al., 2011) and Moringa oleifera (Aliyu et al., 2013). Of all the oil-bearing crops prevalent in the country, palm kernel, groundnut and oil palm are the most abundant and this informed their selection as the preferred feedstocks for biodiesel production in the country's biofuel projects (Ishola et al., 2013). However, this is accomplished at the expense of the food use of these traditional oils.

Almond seeds are included in the family Rosaceae in addition to Pomoideae (apples, pears), Prunoideae (apricot, cherry, peach, and plum) and Rosoideae (blackberry, strawberry) fruits. There are two major varieties of almonds, the bitter almond (Prunus amygdalus "amara") and the sweet almond (Prunus amygdalus "dulcis") used mainly for culinary purposes, and making of oils and flavourings, respectively (Agunbiade and Olanlokun, 2006). Almond (Prunus amygdalus "dulcis") is one of the species of Prunus belonging to the subfamily Prunoideae of the family Rosaceae. Almond seeds contain approximately 51\% lipid, $21 \%$ protein, $20 \%$ carbohydrate and $12 \%$ fiber.

Harnessing the inexpensive and neglected sweet almond seed as raw material for biodiesel production in Nigeria is an effective way to reduce the food-fuel strain on the use of traditional oils (palm oil, groundnut oil and palm kernel oil). The primary aim of the work is 
to investigate the possible use of sweet almond (Prunus amygdalus "dulcis") seed oil as an alternative feedstock for the production of biodiesel in Nigeria.

\section{MATERIALS AND METHODS}

\subsection{Materials}

Fully matured sweet almond fruits (Prunus amygdalus "dulcis") were collected fresh in April, 2012, in front of the Administration building of the College of Engineering and Environmental Studies of Olabisi Onabanjo University, Ifo, Ogun State, Nigeria. The edible portion (flesh) was manually removed, leaving the stony shell containing the seed. The stony shell was carefully cracked to remove the groundnut-like seed. $2 \mathrm{~kg}$ of almond seeds were gathered and sun-dried for two weeks before being milled using a domestic blender. The resulting powder was preserved in polypropylene bags under cool conditions in preparation for oil extraction. The seeds and fruits of sweet almond are shown in Figure 1. Pure fatty acid methyl esters were purchased from Sigma Chemical Co. (USA). The chemicals (analytical grade) supplied from Merck, Germany were: methanol of $99.5 \%$ purity, sodium hydroxide pellets of $85 \%$ purity, sodium sulfate powder of $98 \%$ purity and n-hexane of $99 \%$ purity.

\subsection{Oil extraction}

The lipid components of the milled sweet almond seeds (1000 g) were subsequently extracted with n-hexane using a Soxhlet apparatus at $45-50{ }^{\circ} \mathrm{C}$ for $6-8 \mathrm{~h}$ until the extraction was completed. The solvent was removed from the oil using rotary vacuum evaporator at $65^{\circ} \mathrm{C}$ under reduced pressure. Oil content was calculated from the weight difference of the dried seeds sample before and after extraction. After the extraction process, the oil obtained was stored in a cool dry place pending analysis. The acid value of sweet almond seed oil was measured by the AOCS Official Method Cd 3d-63. The oil content and acid value determinations were performed in triplicate, and the data reported as mean \pm standard deviation.

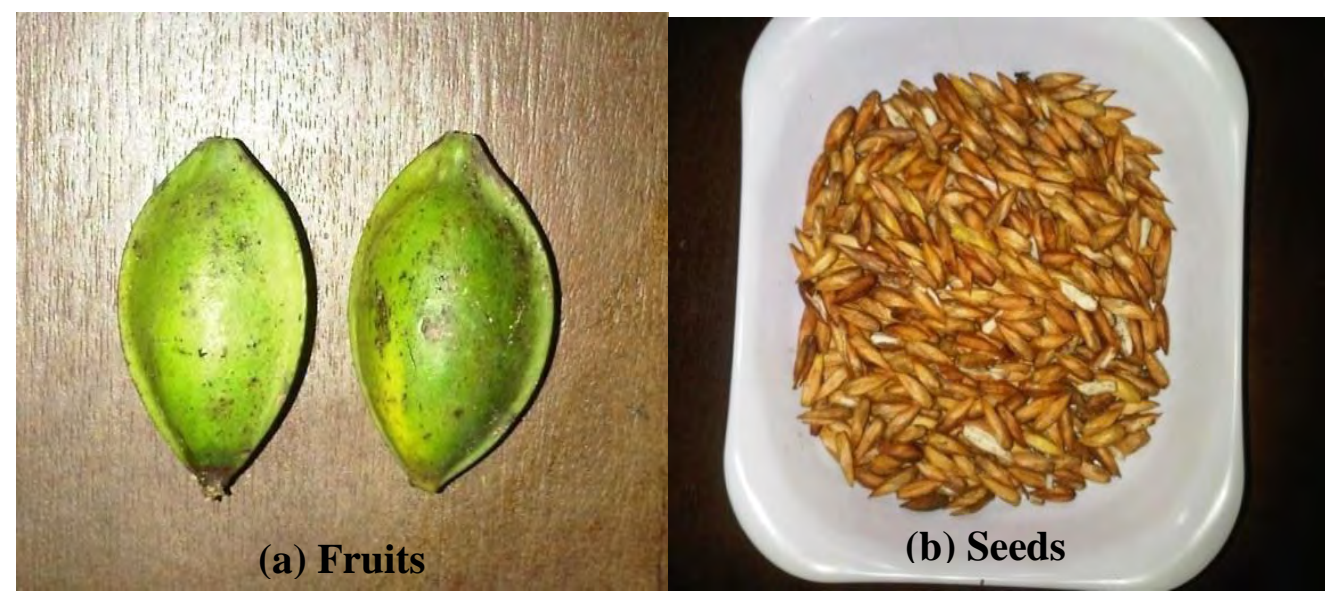

Figure 1. Fruits and seeds of sweet almond.

\subsection{Pretreatment of oil}

Due to the slightly high free fatty acid (FFA) of the sweet almond seed oil (4.90\%) soap formation may occur during the transesterification reaction when alkaline catalyst is used and this will affect the esters yield. Moreover, in the catalytic transesterification, FFA and water always produce negative effects, consuming the catalyst and reducing the catalyst's effectiveness. The oil was pretreated with potassium hydroxide to reduce the FFA to $0.76 \%$. 


\subsection{Transesterification reaction}

The transesterification reaction was carried out in a $2 \mathrm{~L}$ three-necked round bottom reactor equipped with reflux condenser, heater (with magnetic stirrer) and a thermometer. $500 \mathrm{~g}$ of sweet almond seed oil (SASO) was put into the reactor and heated to a temperature of $60{ }^{\circ} \mathrm{C}$. An appropriate amount of methanol $(109.65 \mathrm{~g})$ was poured in a beaker with the required quantity of $\mathrm{NaOH}(5 \mathrm{~g} ; 1 \% \mathrm{w} / \mathrm{w}$ with respect to oil) pellet added to it. The content of the beaker was manually stirred vigorously until the $\mathrm{NaOH}$ was completely dissolved in the methanol to give a mixture (sodium methoxide). The sodium methoxide was poured into the reactor containing the heated oil and the entire content in the reactor was stirred at the rate of $600 \mathrm{rpm}$ (using magnetic stirrer) and the temperature maintained at $60 \pm 1{ }^{\circ} \mathrm{C}$. This marked the commencement of the reaction that was allowed for $1 \mathrm{~h}$, after which the heating and stirring was stopped. The product of the reaction was allowed to cool to room temperature and then poured into a separating funnel to settle down overnight. It was observed that the reaction product had settled into two distinct layers of glycerol (lower) and crude sweet almond oil methyl esters (upper). The crude sweet almond oil methyl esters (SAOME) was collected separately from the separating funnel and heated on a rotary vacuum evaporator under reduced pressure at $80^{\circ} \mathrm{C}$ until the excess methanol was completely removed. Thereafter, the crude SAOME was gently washed (three times) with warm distilled water to remove residual catalyst or soaps. It was then dried with anhydrous sodium sulphate and filtered, and the resulting product (purified SAOME) stored in a cool dry place prior to further analysis. The procedure was repeated in triplicate and the average yield reported.

\subsection{Methyl ester analysis and biodiesel yield}

The fatty acid (FA) composition of SAOME was analyzed by an Agilent gas chromatograph (GC), model 7890A, coupled with flame ionization detector (FID). This was carried out according to the EN 14103 standard method. Separation was done with a DB-WAX capillary column $(30 \mathrm{~m} \times 0.25 \mathrm{~mm}$, I.D x $0.25 \mu \mathrm{m}, 1.0 \mu \mathrm{l}$ and $0.10 \mu \mathrm{m}$; J \& W Scientific, Folsom, CA, USA). Helium was used as the carrier gas. Oven temperature was held at $210^{\circ} \mathrm{C}$ for $9 \mathrm{~min}$ and then increased to $230^{\circ} \mathrm{C}$ (held $10 \mathrm{~min}$ ) at a rate of $20^{\circ} \mathrm{C} / \mathrm{min}$. Injector and detector were set at $250{ }^{\circ} \mathrm{C}$ and $300{ }^{\circ} \mathrm{C}$, respectively. A sample volume of $1.0 \mu \mathrm{L}$ was injected using split mode (split ratio of 1:50). Fatty acid methyl esters were identified by comparing their relative and absolute retention times with those of authentic standards. Quantification was done by Chem Station data handling software incorporated in the GC. The free and total glycerol present in the AOME was analyzed using GC in accordance with ASTM D6584 standard method. The same GC used above was equipped with a capillary column of DB-5HT $(15 \mathrm{~m} \times 0.25 \mathrm{~mm}$, I.D x $0.25 \mu \mathrm{m}, 1.0 \mu \mathrm{l}$ and $0.10 \mu \mathrm{m}$; J \& W Scientific, Folsom, CA, USA).

For the present work, the biodiesel yield was determined using the following Equation 1.

$$
\text { Yield }(\%)=\frac{\text { weight of methyl ester produced }}{\text { weight of oil used in reaction }} \times 100
$$

\subsection{Fuel properties determination}

Biodiesel fuel properties of AOME were determined using standard test methods. The following fuel properties were measured: acid value (ASTM D664), kinematic viscosity (ASTM D4052), cold flow plugging point (ASTM D6371), iodine value (EN 14111), cloud point (ASTM D2500), oxidative stability (EN 14112) and flash point (ASTM D93). The cetane number $(\mathrm{CN})$ of the biodiesel was determined empirically (Ramos et al., 2009). 


\section{RESULTS AND DISCUSSION}

\subsection{Oil content, acid value and biodiesel yield}

Oil content is a key factor influencing the overall choice of sweet almond seed (SAS) as potential feedstock for biodiesel production. SASs was found to contain after extraction $51.45 \pm 3.92 \%(\mathrm{w} / \mathrm{w})$ oil. The oil content of SASs is similar to those of Siberian apricot $(51.15 \pm 7.12 \%)$, Moringa oleifera (51\%), palm kernel $(50 \%)$ and egusi melon $(51 \%)$, and much higher than those of soybean (17\%), cotton (15\%) and tigernut (Cyperus esculentus) (16\%) (Wang 2013; Ishola et al., 2013; Aliyu et al., 2013; Ofoefule et al., 2013; Pinto et al., 2005). The acid value of sweet almond seed oil (SASO) was determined to be $0.38 \mathrm{mg}$ $\mathrm{KOH} / \mathrm{g}$ after pretreating the oil because the initial acid value $(2.45 \mathrm{mg} \mathrm{KOH} / \mathrm{g})$ was slightly higher than the value $(\leq 2 \mathrm{mg} \mathrm{KOH} / \mathrm{g})$ recommended for direct base-catalyzed transesterification. Biodiesel yield of SASO was obtained at $85.9 \%$.

\subsection{Fatty acid profile}

The FA composition in the SASO analyzed was identified as palmitic acid (C16:0; 9.3\%), palmitoleic acid (C16:1; 0.3\%), stearic acid (C18:0; 1.8\%), oleic acid (C18:1; 69.7\%), linoleic acid $(\mathrm{C} 18: 2 ; 18.2 \%)$ and linolenic acid (C18:3, 0.7\%) (Table 1). The percentage of FA composition obtained in this study was closely similar to those of other species of almond previously reported (Chu et al., 2013; Wang, 2013), with the exception of Iranian almond (Atapour and Kariminia, 2011). Also, the FA profile of SASO is close to that of canola oil (Moser and Vaughn, 2010). Of the six FAs, oleic acid was the most prevalent, accounting for $69.7 \%$, and palmitic acid $(9.3 \%)$ was the predominant saturated FA. The total saturated and unsaturated FA contents of the oil are $11.1 \%$ and $88.9 \%$, respectively. Oils with high percentages of monounsaturated FA are ideal biodiesel raw materials (Ramos et al., 2009; Knothe, 2008). Consequently, with 70.0\% monounsaturated FA content, SASO represents a good feedstock for biodiesel production. Because transesterification reaction does not alter FA composition of the oil (SASO), the FA composition of SAOME was not determined (Ramos et al., 2009).

Table 1. Physico-chemical properties and fatty acid compositions of SASO.

\begin{tabular}{l|c}
\hline \multicolumn{1}{c|}{ Property } & Sweet almond seed oil \\
\hline Oil content (wt.\%) & $51.45 \pm 3.92^{\mathrm{a}}$ \\
Acid value (mg KOH/g) & $2.45(0.38)^{\mathrm{b}}$ \\
Free fatty acid (\%) & $4.9(0.76)^{\mathrm{b}}$ \\
\hline \multicolumn{2}{l}{ Fatty acid composition (wt.\%) } \\
\hline Palmitic (C16:0) & 9.3 \\
Palmitoleic (C16:1) & 0.3 \\
Stearic (C18:0) & 1.8 \\
Oleic (C18:1) & 69.7 \\
Linoleic (C18:2) & 18.2 \\
Linolenic (C18:3) & 0.7 \\
Total saturated acids (Cn:0) & 11.1 \\
Total monounsaturated acids (Cn:1) & 70.0 \\
Total polyunsaturated acids (Cn:2,3) & 18.9 \\
Total unsaturated acids & 88.9 \\
Molecular weight (g/mol) & 874.5 \\
\hline
\end{tabular}

${ }^{a}$ Values are mean \pm standard deviation of triplicate determination; ${ }^{b}$ values obtained after the oil pretreatment. 


\subsection{Fuel properties}

\subsubsection{Kinematic viscosity}

Viscosity is a measure of a fuel's flow characteristics and its tendency to deform under stress. Kinematic viscosity (KV) is an important parameter with regard to fuel atomization as well as fuel distribution. The KV of biodiesel is significantly influenced by the feedstock used. The KV of sweet almond oil biodiesel at $40{ }^{\circ} \mathrm{C}$ was determined to be $4.23 \mathrm{~mm}^{2} / \mathrm{s}$, which is within the ranges specified by ASTM D6751 and EN 14214 (Table 2). Since SAOME contained a large amount of unsaturated FAs $(88.9 \%)$ and a considerable percentage of monounsaturated FAs $(70.0 \%)$, it exhibited a slightly high KV.

\subsubsection{Oxidative stability}

Oxidative stability (OS) is an important technical issue affecting biodiesel quality (Knothe, 2008). A minimum Rancimat induction period of 3 and $6 \mathrm{~h}$ is defined for biodiesel fuel using ASTM D6751 and EN 14214 standards, respectively. As provided in Table 2, sweet almond biodiesel OS $(3.1 \mathrm{~h})$ was slightly higher than that recommended by ASTM D6751 (3 h) and lower than that specified by EN $14214(6 \mathrm{~h})$. The relatively good OS of SAOME may be attributed to the slightly low percentage of methyl linoleate $(18.2 \%)$, which has an OS of $0.94 \mathrm{~h}$ (Knothe, 2008). Addition of antioxidants can help improve the OS of SAOME (Chu et al., 2013), but will increase the cost of the biodiesel product. However, an inexpensive alternative solution to the problem of OS involves blending biodiesel with diesel fuel.

\subsubsection{Flash point}

Flash point (FP) of a fuel is the temperature at which it will ignite when exposed to a flame or spark. Biodiesel with a higher FP than petro-diesel possesses the benefit of higher safety for transport purposes. The biodiesel produced from SASO had a FP $\left(169{ }^{\circ} \mathrm{C}\right)$ greater than conventional diesel $\left(77^{\circ} \mathrm{C}\right.$ ) by $92{ }^{\circ} \mathrm{C}$ (Table 2$)$. This value is significantly above the minimum limits prescribed in ASTM D6751 and EN 14214 standards.

\subsubsection{Cetane number}

The cetane number $(\mathrm{CN})$ measures the tendency of the fuel to self-ignite at the temperature and pressure in the cylinder when the fuel is injected. It is one of the key parameters considered in the use of methyl esters as fuel since a satisfactory $\mathrm{CN}$ is required for good engine performance. As presented in Table 2, the calculated CN for SAOME was 58.3. This value is reasonable considering that the FA composition of SASO mainly consisted of $69.7 \%$ oleic acid and $18.2 \%$ linoleic acid, and the CN of pure methyl linoleate and methyl oleate are 38.2 and 59.2, respectively (Chu et al., 2013; Knothe et al., 2008). The CN determined for SAOME satisfies both ASTM D6751 and EN 14124 quality standards that set minimum limits of 47 and 51, respectively.

\subsubsection{Cold flow}

The cold flow properties of SAOME were measured by determination of cloud point (CP) and pour point (PP). CP and PP are important low-temperature fuel parameters. The CP is the temperature at which crystal growth is large enough to be visible to the naked eye while the PP is the lowest temperature at which the fluid will pour. Specifications for CP and PP are not in the biodiesel standards, although ASTM D6751 requires that CP be reported; this is because each country has different climatic conditions. As presented in Table 2, the sweet almond biodiesel has satisfactory $\mathrm{CP}$ of -3 and PP of $-9{ }^{0} \mathrm{C}$. These values are mostly good because the SASO FAs composition has a high percentage $(90.4 \%)$ of long-chain unsaturated FAs (Table 1). 
Table 2. Fuel properties of the sweet almond oil methyl ester compared with biodiesel standards.

\begin{tabular}{|c|c|c|c|c|}
\hline \multirow{2}{*}{ Property } & \multirow{2}{*}{ Unit } & \multicolumn{2}{|c|}{ Limits } & \multirow{2}{*}{ SAOME } \\
\hline & & ASTM D6751 & EN 14214 & \\
\hline Kinematic viscosity; $40^{\circ} \mathrm{C}$ & $\mathrm{mm}^{2} / \mathrm{s}$ & $1.9-6.0$ & $3.5-5.0$ & 4.23 \\
\hline Flash point & ${ }^{\circ} \mathrm{C}$ & $130 \mathrm{~min}$ & $120 \mathrm{~min}$ & 169 \\
\hline Cloud point & ${ }^{\circ} \mathrm{C}$ & Report & $-*$ & -3 \\
\hline Acid value & $\mathrm{mg} \mathrm{KOH} / \mathrm{g}$ & $0.5 \max$ & $0.50 \max$ & 0.13 \\
\hline Linolenic acid content & $\%(\mathrm{~mol} / \mathrm{mol})$ & $-*$ & $12.0 \max$ & 0.7 \\
\hline Oxidative stability & $\mathrm{h}$ & $3 \mathrm{~min}$ & $6 \min$ & 3.1 \\
\hline Pour point & ${ }^{\circ} \mathrm{C}$ & $-^{*}$ & $-{ }^{*}$ & -9 \\
\hline Cetane number & & $47 \mathrm{~min}$ & $51 \mathrm{~min}$ & $58^{\mathrm{a}}$ \\
\hline Free glycerol & $\operatorname{mass} \%$ & $0.02 \max$ & $0.02 \max$ & 0.013 \\
\hline Total glycerol & $\operatorname{mass} \%$ & $0.24 \max$ & $0.25 \max$ & 0.172 \\
\hline
\end{tabular}

*Not specified; ${ }^{\mathrm{a}}$ Empirically determined.

\subsubsection{Acid value}

Acid value (AV) is a measure of the FFA content in the biodiesel and is expressed as the milligram of $\mathrm{KOH}$ required to neutralize the FFAs in 1 gram of the sample. The AV of the sweet almond oil biodiesel produced in the present work was $0.21 \mathrm{mg}$ of $\mathrm{KOH} / \mathrm{g}$. The AV of sweet almond oil biodiesel satisfied this specification $(0.5 \mathrm{mg} \mathrm{KOH} / \mathrm{g})$, and is an indication of good biodiesel quality in this regard. As seen in Table 2, the AV of SAOME $(0.21 \mathrm{mg}$ $\mathrm{KOH} / \mathrm{g}$ ) conforms to ASTM D6751 and EN 14214 standards.

\subsubsection{Iodine value}

The iodine value (IV) is an index of the number of double bonds within a mixture of FA contained in biodiesel. Therefore, it is a measure of the total unsaturation of a fatty material measured in grams of iodine per $100 \mathrm{~g}$ of sample when iodine is formally added to the double bonds. The IV of sweet almond oil biodiesel was $92.3 \mathrm{~g} \mathrm{I}_{2} / 100 \mathrm{~g}$. The result satisfied the specification of $120 \mathrm{~g} \mathrm{I}_{2} / 100 \mathrm{~g}$ (maximum) recommended by EN 14214 standards, as shown in Table 2.

\subsubsection{Other fuel properties}

Other fuel properties of sweet almond oil biodiesel, such as free glycerin and total glycerin, were also determined (Table 2). Expectedly, these aforementioned properties of sweet almond oil biodiesel complied with EN 14214 and ASTM D6751 standards. Also, the linolenic acid contained in the SASO (0.7\%) is significantly lower than the $12 \%$ recommended by EN 14214 (Table 1).

\section{CONCLUSIONS}

SASs have considerable oil content (over 50\%) which underwent pre-treatment prior to direct transesterification. The conversion of SASO into methyl esters via alkaline transesterification was investigated in order to find a feedstock suitable for biodiesel production in Nigeria that is not also in demand as food. Selected fuel properties of SAOME 
were measured $\left(\mathrm{KV}=4.23 \mathrm{~mm}^{2} / \mathrm{s}, \mathrm{FP}=169^{\circ} \mathrm{C}, \mathrm{OS}=3.1 \mathrm{~h}, \mathrm{CN}=58, \mathrm{CP}=-3^{\circ} \mathrm{C}\right.$ and $\mathrm{PP}=$ $9{ }^{\circ} \mathrm{C}$ ) and compared to the biodiesel standards (ASTM D6751 and EN 14214), and a satisfactory agreement with these standards was observed. Also, the feedstock (SASO) was analyzed to contain six FAs, of which oleic acid (69.7\%) is the most predominant. Finally, SASO seems a potential substitute for palm oil, groundnut oil and palm kernel oil, which are the predominant oils available in the country as feedstocks for biodiesel production.

\section{ACKNOWLEDGEMENTS}

We hereby acknowledge the immeasurable contributions and support of Miss Oluwaseun Akinwoye and Mrs. Tessy Oguntoyinbo of Bells University of Technology, Ota, Ogun State, Nigeria during the course of this research.

\section{REFERENCES}

AGUNBIADE, S. O.; OLANLOKUN, J. O. Evaluation of some nutritional characteristics of Indian almond (Prunus amygdalus) Nut. Pakistan J. Nutr, v. 5, p. 316-318, 2006.

ALAMU, O. J.; DEHINBO, O.; SULAIMAN, A. M. Production and testing of coconut oil biodiesel fuel and its blend. Leonardo J. Sci., v. 16, p. 95-104, 2010.

ALAMU, O. J.; WAHEED, M. A.; JEKAYINFA, S.O. Effect of ethanol-palm kernel oil ratio on alkali-catalyzed biodiesel yield, Fuel, v. 87, p. 1529-1533. 2008. http://dx.doi.org/10.1016/j.fuel.2007.08.011.

ALIYU, A. O.; NWAEDOZIE, J. M.; ADAMS, A. Quality parameters of biodiesel produced from locally sourced moringa oleifera and citrullus colocynthis 1 . Seeds found in Kaduna, Nigeria. Int. Res. J. Pure Appl. Chem., v. 3, p. 377-390, 2013.

ATAPOUR, M.; KARIMINIA, H. R. Characterization and transesterification of Iranian bitter almond oil for biodiesel production. Appl. Energy, v. 88, p. 2377-2381, 2011. http://dx.doi.org/10.1016/j.apenergy.2011.01.014

BALAT, M.; BALAT, H. A critical review of biodiesel as vehicular fuel. Energy Convers. Manag., v. 49, p. 2727-2741, 2008. http://dx.doi.org/10.1016/j.enconman.2008.03.016

BAMGBOYE, A. I.; ONIYA, O. O. Fuel properties of loofah (Luffa cylindrica L.) biofuel blended with diesel. Afr. J. Environ. Sci. Technol., v. 6, p. 346-352, 2012.

BELLO, E. I.; FADE-ALUKO, A. O.; ANJORIN, S. A.; MOGAJI, T. S. Characterization and evaluation of African bush mango Nut (Dika nut) (Irvingia gabonensis) oil biodiesel as alternative fuel for diesel engines. J. Petro. Technol. Alter. Fuels, v. 2, p. 176-180, 2011.

CHU, J. M.; XU, X. Q.; ZHANG, Y. L. Production and properties of biodiesel produced from Amygdalus pedunculata Pall. Bioresour. Technol., v. 134, p. 374-376, 2013.

DEMIRBAS, A. Importance of biodiesel as transportation fuel. Energy Policy, v. 35, p. 4661-4670, 2007. http://dx.doi.org/10.1016/j.enpol.2007.04.003

GIWA, S. O.; CHUAH, L. A.; ADAM, N. M. Investigating "Egusi"(Citrullus Colocynthis L.) Seed oil as potential biodiesel feedstock. Energies, v. 3, p. 607-618, 2010. http://dx.doi.org/10.3390/en3040607 
ISHOLA, M. M.; BRANDBERG, T.; SANNI, S. A.; TAHERZADEH, M. J. Biofuels in Nigeria: a critical and strategic evaluation. Renew. Energy, v. 55, p. 554-560, 2013. http://dx.doi.org/10.1016/j.renene.2012.12.021

IZAH, S. C.; OHIMAIN, E. I. The Challenge of Biodiesel Production from Oil Palm Feedstock in Nigeria. Greener Journal of Biological Sciences, v. 3, p. 1-12, 2013.

KNOTHE, G. "Designer" biodiesel: optimizing fatty ester composition to improve fuel properties. Energy Fuels, v. 22, p. 1358-1364, 2008. http://dx.doi.org/10.1021/ef700639e

MOSER, B. R.; VAUGHN, S. F. Evaluation of alkyl esters from Camelina sativa oil as biodiesel and as blend components in ultra low-sulfur diesel fuel. Bioresour. Technol., v. 101. p. 646-653, 2010. http://dx.doi.org/10.1016/j.biortech.2009.08.054

OFOEFUlE, A. U.; IBETO, C. N.; OKORO, U. C.; ONUKWULI, O. D. Biodiesel Production from Tigernut (Cyperus esculentus) Oil and Characterization of its Blend with Petro-diesel. Phy. Rev. Res. Int.l, v. 3, p. 145-153, 2013.

PINTO, A. C.; GUARIEIRO, L. L. N.; REZENDE, M. J. C.; RIBEIRO, N. M.; TORRES, E. A.; LOPES, W. A. et al. Biodiesel: an overview. J. Braz. Chem. Soc., v. 16, p. 13131330, 2005. http://dx.doi.org/10.1590/S0103-50532005000800003

RAMOS, M. J.; FERNANDEZ, C. M.; CASAS, A.; RODRIGUEZ, L.; PEREZ, A. Influence of fatty acid composition of raw materials on biodiesel properties. Bioresour. Technol., v. 100, p. 261-268, 2009. http://dx.doi.org/10.1016/j.biortech.2008.06.039

RASHID, U.; ANWAR, F.; MOSER, B. R.; ASHRAF, S. Production of sunflower oil methyl esters by optimized alkali-catalyzed methanolysis. Biomass Bioenergy, v. 32, p. $1202-$ 1205, 2008. http://dx.doi.org/10.1016/j.biombioe.2008.03.001

WANG, L. Properties of Manchurian apricot (Prunus mandshurica Skv.) and Siberian apricot (Prunus sibirica L.) seed kernel oils and evaluation as biodiesel feedstocks. Ind. Crops Prod., v. 50, p. 838-843, 2013. http://dx.doi.org/10.1016/j.indcrop.2013.08.072 


Ambiente \& Água - An Interdisciplinary Journal of Applied Science
ISSN 1980-993X - doi:10.4136/1980-993X
www.ambi-agua.net
E-mail: ambi-agua@agro.unitau.br

\title{
Accumulation and recovery capacity of heavy metals in sand mine ponds of the Otamiri River in Owerri, Nigeria
}

\author{
doi: 10.4136/ambi-agua.1226
}

Received: 22 Oct 2013; Accepted: 22 Feb. 2014

\author{
Dike Henry Ogbuagu* ; Comfort Barikpoa Samuel \\ Federal University of Technology, Owerri, Imo State, Nigeria \\ Department of Environmental Technology \\ *Corresponding author: e-mail: henrydike2002@yahoo.com, \\ commykids@yahoo.com
}

\begin{abstract}
This study investigated the levels, index of accumulation and recovery capacity of heavy metals $(\mathrm{Pb}, \mathrm{Cd}, \mathrm{Cu}, \mathrm{Ni}, \mathrm{Zn}, \mathrm{Fe}, \mathrm{Mn})$ in sand mine ponds of the Otamiri River in Owerri, Nigeria during the wet season of 2012. Water (WC) and sediment samples (SD) were collected from six sampling points, with WC 1-WC 3 and SD 1-SD 3 located within a derelict mine pond and WC 4-WC 6 and SD 4-SD 6 located within an actively mined pond. The $\mathrm{pH}$ was determined in situ and levels of heavy metals measured with the atomic absorption spectrophotometer. The student's t-test, index of geoaccumulation $\left(\mathrm{I}_{\mathrm{geo}}\right)$, accumulation factor (AF) and pond recovery capacity (PRC) were computed for the ponds. There was significant spatial heterogeneity in mean levels of the heavy metals in sediments (sig. $\mathrm{t}=0.029)$ at $\mathrm{P}<0.05$, with higher levels of metals also recorded in sediments than water columns. The order of $\mathrm{I}_{\text {geo }}$ was $\mathrm{Fe}(5.959)>\mathrm{Zn}(4.932)>\mathrm{Cu}(4.743)>\mathrm{Mn}(4.326)>\mathrm{Pb}(3.214)>\mathrm{Ni}(2.483)>\mathrm{Cd}$ (1.649), AF was $\mathrm{Zn}(1.513)>\mathrm{Cd}(1.179)>\mathrm{Fe}(1.082)>\mathrm{Ni}(1.048)>\mathrm{Mn}(1.042)>\mathrm{Cu}$ $(1.032)>\mathrm{Pb}(0.987)$ and $\mathrm{PRC}$ was $\mathrm{Zn}(33.891)>\mathrm{Cd}(15.165)>\mathrm{Fe}(7.604)>\mathrm{Ni}(4.608)>\mathrm{Mn}$ $(4.047)>\mathrm{Cu}(3.052)>\mathrm{Pb}(-1.373)$. Active mining led to extreme contamination of the ponds with $\mathrm{Fe}$, strong to extreme contaminations with $\mathrm{Cu}, \mathrm{Zn}$ and $\mathrm{Mn}$, strong contamination with $\mathrm{Pb}$, moderate to strong contamination with $\mathrm{Ni}$ and moderate contamination with $\mathrm{Cd}$. However, $\mathrm{Pb}$ showed deficit recovery capacity and this could portend unfavourable ecological consequences on resident biota and raises public health concerns among resource dependants of the river. Strict enforcement of regulations on in-stream sand mining should be applied.
\end{abstract}

Keywords: in-stream sand mining, geoaccumulation index, pond recovery capacity, sediments.

\section{Acumulação e capacidade de recuperação de metais pesados em lagoas de mineração de areia do Rio Otamiri em Owerri, Nigéria}

\section{RESUMO}

Níveis, índice de acumulação e recuperação da capacidade de metais pesados $(\mathrm{Pb}, \mathrm{Cd}$, $\mathrm{Cu}, \mathrm{Ni}, \mathrm{Zn}, \mathrm{Fe}, \mathrm{Mn}$ ) em lagoas de mineração de areia do Rio Otamiri em Owerri, Nigéria, foram investigados durante a estação chuvosa de 2012. Amostras de água (WC) e de sedimentos (SD) foram coletadas em seis pontos de amostragem, sendo os pontos WC 1 - WC 3 e SD 1 - SD 3 localizados dentro de uma lagoa de mineração abandonada e WC 4 - WC 6 e 
SD 4 - SD 6 localizados dentro de uma lagoa de mineração ativa. $\mathrm{O}$ pH foi determinado in situ e os metais pesados determinados em espectrofotômetro de absorção atômica. O teste-t de Student, o índice de geoacumulação $\left(\mathrm{I}_{\mathrm{geo}}\right)$, o fator de acumulação (AF) e a capacidade de recuperação das lagoas (PRC) foram computados para as lagoas. Houve heterogeneidade espacial significativa nos níveis médios dos metais pesados nos sedimentos (sig. $t=0,029)$ para $\mathrm{P}<0,05$, com níveis mais elevados de metais registrados nos sedimentos do que nas colunas de água. A ordem do $\mathrm{I}_{\text {geo }}$ foi $\mathrm{Fe}(5,959)>\mathrm{Zn}(4,932)>\mathrm{Cu}(4,743)>\mathrm{Mn}(4.326)>\mathrm{Pb}$ $(3,214)>\mathrm{Ni}(2,483)>\mathrm{Cd}(1,649)$, do AF foi $\mathrm{Zn}(1,513)>\mathrm{Cd}(1,179)>\mathrm{Fe}(1,082)>\mathrm{Ni}$ $(1,048)>\mathrm{Mn}(1,042)>\mathrm{Cu}(1,032)>\mathrm{Pb}(0,987)$ e da PRC foi de $\mathrm{Zn}(33,891)>\mathrm{Cd}(15,165)>$ $\mathrm{Fe}(7,604)>\mathrm{Ni}(4,608)>\mathrm{Mn}(4,047)>\mathrm{Cu}(3,052)>\mathrm{Pb}(-1,373)$. A mineração em atividade causou contaminação extrema da lagoa com Fe, contaminações forte a extrema com $\mathrm{Cu}, \mathrm{Zn}$ e $\mathrm{Mn}$, contaminação forte com $\mathrm{Pb}$, contaminação moderada a forte com $\mathrm{Ni}$ e contaminação moderada com $\mathrm{Cd}$. No entanto, o $\mathrm{Pb}$ mostrou déficit de capacidade de recuperação e isso poderia trazer consequências ecológicas desfavoráveis na biota residente e gera preocupações com saúde pública entre os dependentes dos recursos do rio. Deve ser aplicada regulamentação rigorosa sobre mineração de areia nos cursos d'água.

Palavras-chave: mineração de areia em rios, índice de geoacumulação, capacidade de recuperação da lagoa, sedimentos.

\section{INTRODUCTION}

Sediment is used in a variety of ways to monitor and assess the overall health of the aquatic ecosystem, including the tracking of long-term monitoring programs relating to anthropogenic impacts. Other applications utilize macrobenthos, which are fauna living on or in the sediments as indicators of water quality (Ogbuagu et al., 2011); even as monitoring of recalcitrant pollutants such as the heavy metals have also been done using the sediment matrix (Lima, 2001; Baggio, 2008; Baggio and Heinrich, 2012).

In water pollution studies, sediment reflects not only the quality of the aquatic system, but also the contaminants that do not remain soluble after entry in surface waters. They act as carriers of potential pollution sources that are not permanently fixed and so are reservoirs for reintroduction of pollutant species, especially when perturbed in the face of changing environmental conditions such as $\mathrm{pH}$, redox potential and the presence of organic chelating agents (Baggio and Heinrich, 2012). Consequently, sediments have been characterized as natural barriers to pollutants due to the reactions of sorption, solubility, precipitation and complexation caused by contaminants and control parameters such as $\mathrm{pH}$, Eh, as well as sediment texture, particle size, proportion and types of clay minerals, among others (Meurer et al., 2000).

The Otamiri River is one of the major surface waters that serve the city of Owerri in southeastern Nigeria, providing for domestic source of water, fisheries and artisanal sand mining by the inhabitants. In recent times, the demands of increasing population and associated urbanization have placed serious pressure on such sediment resources of the river as sand, mostly used for buildings and other infrastructural constructions in the city. Concurrently, several mine ponds have been created as relics of river-bank mining along the course of the river, even as some are still currently mined in the study area. These semi-lentic ponds could thus harbour pollutants for a longer residency time of possible recovery from pollution loadings.

Being a reservoir for several pollutants such as heavy metals, an increase of in-stream sand mining could perturb the sink and re-introduce these pollutants into water column in higher, toxic levels. Though the process of self-purification could alleviate pollutant loadings in the derelict mine ponds (Ernestova and Seminova, 1994), this has not been investigated in 
the study area. This study therefore investigated the levels of heavy metals, their accumulation index and recovery potentials in sand mine ponds in line with effective pollution management and resource sustainability.

\section{MATERIALS AND METHODS}

\subsection{Study Area}

Owerri lies within latitude $05^{\circ} 29^{\prime} 06$ s and longitude $07^{\circ} 02^{\prime} 06$ s in southeastern Nigeria (Figure 1). The city experiences a wet season from April to November and a dry season for the rest of the year (Victor et al., 2011). Mean daily maximum temperature is between 28 and $35^{\circ} \mathrm{C}$, while daily minimum values range between 19 and $24{ }^{\circ} \mathrm{C}$. Average humidity of up to $80 \%$ prevails in the region. Semi-deciduous forest vegetation that had been altered by agricultural and other anthropogenic activities covers the area (Onweremadu et al., 2008) and the dominant top-soil is moderately humus in composition. The Otamiri River is one of the two major surface waters that traverse the city.

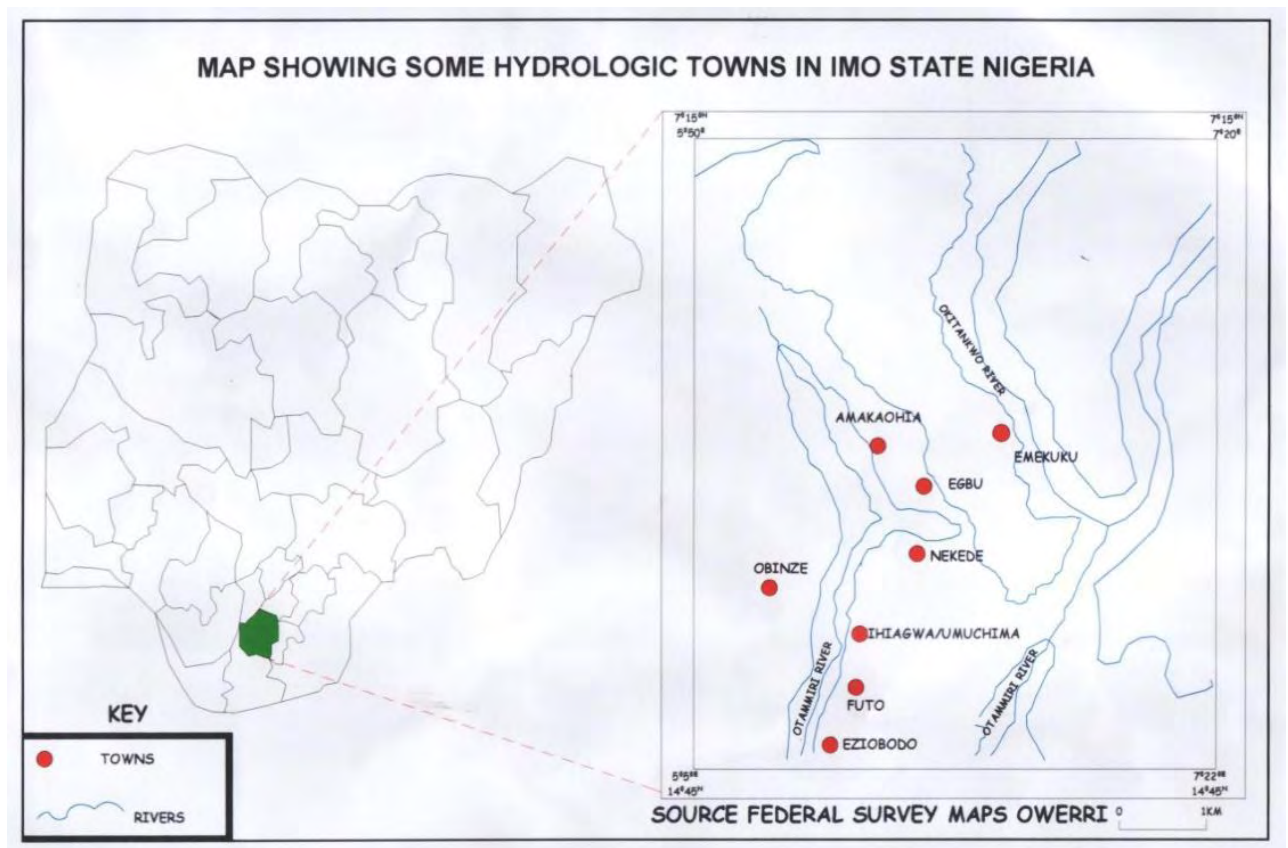

Figure 1. Location map of Nigeria showing Otamiri River in Owerri, Imo State.

\subsection{Field Sampling}

\subsubsection{Sampling locations}

Six sampling points were established about $30 \mathrm{~m}$ apart at the middle course of the river, between Nekede and Eziobodo, and were designated as WC 1-WC 6 and SD 1-SD 6 for water column and sediment samples respectively; with WC 1-WC 3 and SD 1-SD 3 located within a derelict mine pond and WC 4-WC 6 and SD 4-SD 6 located within a pond where active mining was ongoing. Samples were collected and taken to the laboratory as soon as possible on same day and according to standard methods of APHA et al. (1998).

\subsubsection{Field measurements}

In situ determination of $\mathrm{pH}$ was made with a pre-calibrated HANNA HI 9828 $\mathrm{pH} / \mathrm{ORP} / \mathrm{EC} / \mathrm{DO}$ meter in water columns and sediments of the ponds.

\subsection{Laboratory Analysis}


The levels of the heavy metals were determined by the atomic absorption spectrophotometric method (APHA et al., 1998). $5 \mathrm{~g}$ of sediment sample was weighed into $500 \mathrm{~mL}$ flask, $10 \mathrm{~mL}$ of $\mathrm{HNO}_{3}$ was added, and the sample was digested by heating in a fume chamber. $10 \mathrm{~mL}$ of distilled water was added and the sample was filtered. Direct aspiration of digested samples (including water column samples) was carried out into an air/acetylene flame generated by a hollow cathode lamp at a specific wavelength peculiar only to the metals.

\subsection{Statistical Analysis}

The student's t-test of significance was used to compare levels of heavy metals in the derelict and actively mined ponds. The index of geoaccumulation $\left(\mathrm{I}_{\mathrm{geo}}\right)$, given as:

$\mathbf{I}_{\mathbf{g e o}}=\ln \left(\mathbf{C}_{\mathrm{n}} / \mathbf{1 . 5} \mathbf{B}_{\mathrm{n}}\right)$ (Müller, 1979), (where $\mathrm{C}_{\mathrm{n}}=$ measured level of element $\mathrm{n}, \mathrm{B}_{\mathrm{n}}=$ geochemical background level of element $n$, and 1.5 is factor representing possible variations of background data due to lithogenic impacts) and accumulation factor (AF) given as:

$\mathbf{A F}=$ average level of a given parameter downstream/corresponding average level

Upstream (Fakayode, 2005) were used to estimate accumulation of the heavy metals in sediments of the ponds. Pond recovery capacity (PRC) (Ernestova and Seminova, 1994, as modified by Fakayode, 2005), and given as:

$\mathbf{P R C}=\left(\mathbf{S}_{\mathbf{0}}-\mathbf{S}_{1}\right) / \mathbf{S}_{\mathbf{0}} \times \mathbf{1 0 0 \%}$ (where $\mathrm{S}_{0}=$ level of a parameter downstream, $\mathrm{S}_{1}=$ corresponding average level of the parameter upstream) was also computed for the metal pollutants.

\section{RESULTS}

\subsection{Levels of heavy metals in water columns and sediments}

At the $\mathrm{pH}$ ranges of 3.76-4.42 (4.03 \pm 0.10$)$ and 3.99-4.38 (4.17 \pm 0.07$)$, the levels of the heavy metals varied as follows: $\mathrm{Pb}, 0.28-0.95(0.69 \pm 0.12) \mathrm{mg} \mathrm{L}^{-1}$ and $4.30-7.88$ $(6.11 \pm 0.54) \mathrm{mg} \mathrm{kg}^{-1} ; \mathrm{Cd}, 0.64-1.58(1.12 \pm 0.15) \mathrm{mg} \mathrm{L}^{-1}$ and $2.41-3.70(2.80 \pm 0.19) \mathrm{mg} \mathrm{kg}^{1}$; $\mathrm{Cu}, 4.00-6.40(5.04 \pm 0.38) \mathrm{mg} \mathrm{L}^{-1}$ and 10.80-16.45 (13.12 \pm 0.97$) \mathrm{mg} \mathrm{kg}^{-1} ; \mathrm{Ni}, 1.20-1.92$ $(1.60 \pm 0.11) \mathrm{mg} \mathrm{L}^{-1}$ and 3.18-6.00 (4.24 \pm 0.42$) \mathrm{mg} \mathrm{kg}^{-1} ; \mathrm{Zn}, 4.50-6.20(5.17 \pm 0.26) \mathrm{mg} \mathrm{L}^{-1}$ and 9.20-20.82 (14.73 \pm 1.81$) \mathrm{mg} \mathrm{kg}^{-1}$; Fe, 5.80-8.82 (7.13 \pm 0.44$) \mathrm{mg} \mathrm{L}^{-1}$ and 20.20-28.60 $(24.12 \pm 1.63) \mathrm{mg} \mathrm{kg}^{-1}$; Mn, 2.50-4.80 (3.15 \pm 0.35$) \mathrm{mg} \mathrm{L}^{-1}$ and $10.00-11.80(10.65 \pm 0.26)$ $\mathrm{mg} \mathrm{kg}{ }^{-1}$ in water columns and sediments respectively. However, $\mathrm{Hg}$, As and Co were undetected in both water columns and sediment samples.

\subsection{Spatial variations in levels of heavy metals}

In the water columns, minimum $\left(0.28 \mathrm{mg} \mathrm{L}^{-1}\right)$ and maximum levels of $\mathrm{Pb}\left(0.95 \mathrm{mg} \mathrm{L}^{-1}\right)$ were recorded in WC 6 and WC 1, while in sediments, minimum and maximum levels of 4.30 and $7.88 \mathrm{mg} \mathrm{kg}^{-1}$ were recorded in SD 5 and SD 6 respectively (Figure 2). Minimum and maximum levels of $\mathrm{Cd}$ in water columns $\left(0.64\right.$ and $\left.1.58 \mathrm{mg} \mathrm{L}^{-1}\right)$ were recorded in WC 6 and WC 2 while in sediments, minimum and maximum values of 1.80 and $3.70 \mathrm{mg} \mathrm{kg}^{-1}$ were recorded in SD 6 and SD 5 respectively (Figure 3). However, for $\mathrm{Cu}$ (Figure 4) and $\mathrm{Ni}$ (Figure 5) in the water columns, minimum $\left(4.00 \& 1.20 \mathrm{mg} \mathrm{L}^{-1}\right)$ and maximum levels $\left(6.40 \& 1.92 \mathrm{mg} \mathrm{L}^{-1}\right)$ were recorded in WC $6 \& \mathrm{WC} 1$, and WC $1 \& \mathrm{WC} 3$, and in the sediments, minimum $\left(10.80 \& 3.42 \mathrm{mg} \mathrm{kg}^{-1}\right)$ and maximum levels $\left(16.45 \& 6.00 \mathrm{mg} \mathrm{kg}^{-1}\right)$ were recorded in SD $1 \&$ SD 3, and SD 4 \& SD 6 respectively.

In the water columns, $\mathrm{Zn}, \mathrm{Fe} \& \mathrm{Mn}$ recorded minimum levels of $4.50,5.80 \& 2.50 \mathrm{mg} \mathrm{L}^{-1}$ in WC 6 , WC $3 \&$ WC 1, while the respective maximum levels of $6.20,8.82 \& 4.80 \mathrm{mg} \mathrm{L}^{-1}$ were recorded in WC 1 (Figure 6), WC 4 (Figure 7) \& WC 5 (Figure 8). However, in 
sediments, minimum levels $\left(9.20,20.20 \& 10.00 \mathrm{mg} \mathrm{kg}^{-1}\right)$ were recorded in SD 1 , SD 1 \& SD 2, while maximum levels $\left(20.82,28.60 \& 11.80 \mathrm{mg} \mathrm{kg}^{-1}\right)$ were recorded in SD 4, SD 6 \& SD 5 respectively.

A pair-wise student's t-test in pooled levels of the heavy metals between the actively mined (WC\&SD 4- WC\&SD 6) and derelict ponds (WC\&SD 1- WC\&SD 3) revealed significant heterogeneity ( sig. $\mathrm{t}=0.029$ ) in sediment samples but homogeneity ( $\operatorname{sig} . \mathrm{t}=0.686$ ) in water columns at $\mathrm{P}<0.05$.

\subsection{Index of accumulation and recovery capacity}

A transition in levels of the heavy metals from the sediments of the actively mined to the derelict ponds revealed that Fe showed the highest $\mathrm{I}_{\text {geo }}$ (5.959) and $\mathrm{Zn}$ the highest AF (1.513) and PRC (33.891) (Table 1). Of the detectable metals however, while the least $\mathrm{I}_{\text {geo }}$ was exhibited in Cd (1.649), least AF (0.987) and even deficit PRC (-1.373) were exhibited in $\mathrm{Pb}$ concentrations in sediments. Between the actively mined and derelict ponds, the order of $\mathrm{I}_{\text {geo }}$ was $\mathrm{Fe}>\mathrm{Zn}>\mathrm{Cu}>\mathrm{Mn}>\mathrm{Pb}>\mathrm{Ni}>\mathrm{Cd}$, AF was $\mathrm{Zn}>\mathrm{Cd}>\mathrm{Fe}>\mathrm{Ni}>\mathrm{Mn}>\mathrm{Cu}>\mathrm{Pb}$ and $\mathrm{PRC}$ was $\mathrm{Zn}>$ $\mathrm{Cd}>\mathrm{Fe}>\mathrm{Ni}>\mathrm{Mn}>\mathrm{Cu}>\mathrm{Pb}$.

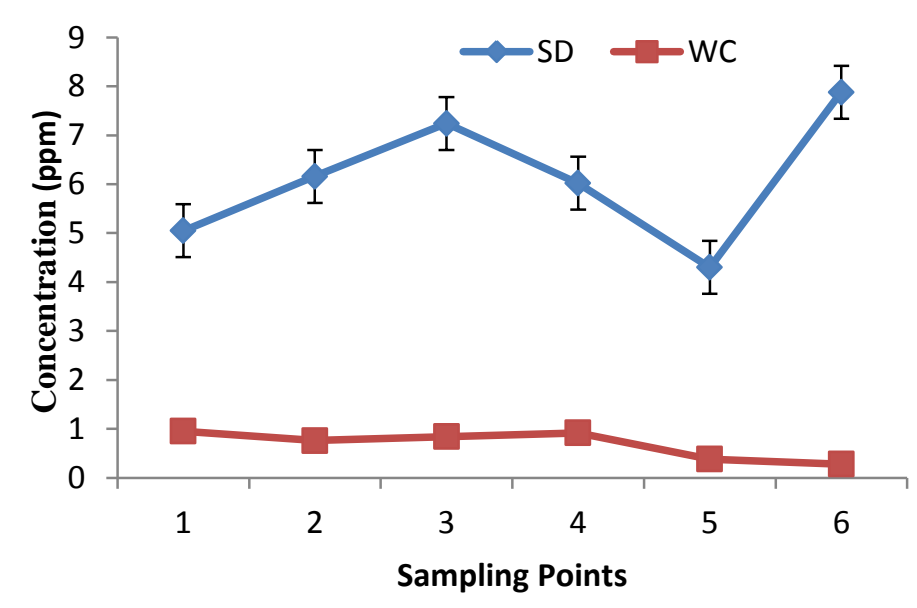

Figure 2. Spatial variations in levels of lead in sediments and water columns of Otamiri River, Owerri.

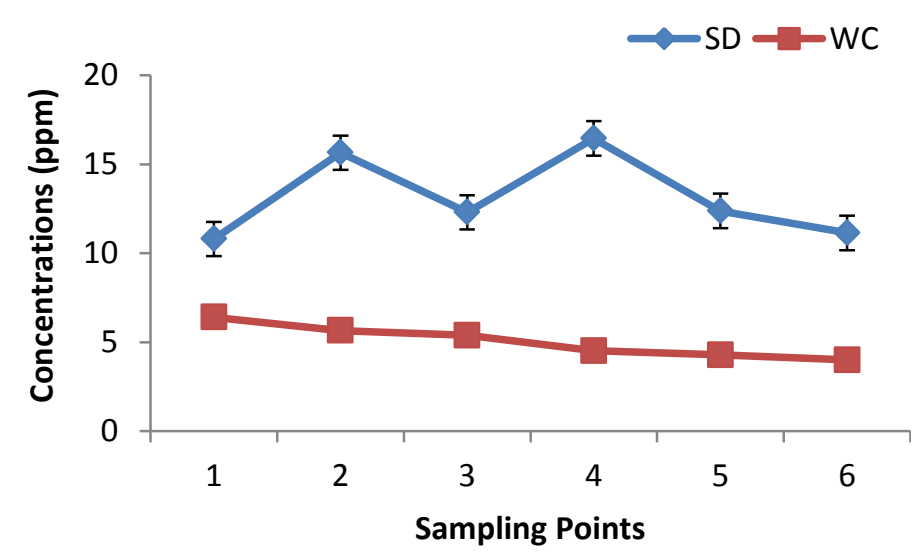

Figure 4. Spatial variations in levels of copper in sediments and water columns of Otamiri River, Owerri.

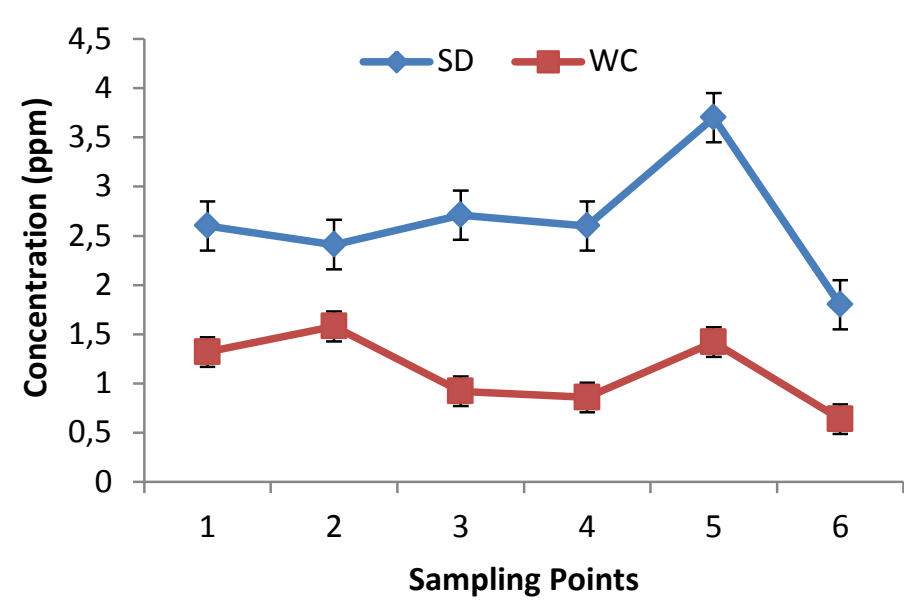

Figure 3. Spatial variations in levels of cadmium in sediments and water columns of Otamiri River, Owerri.

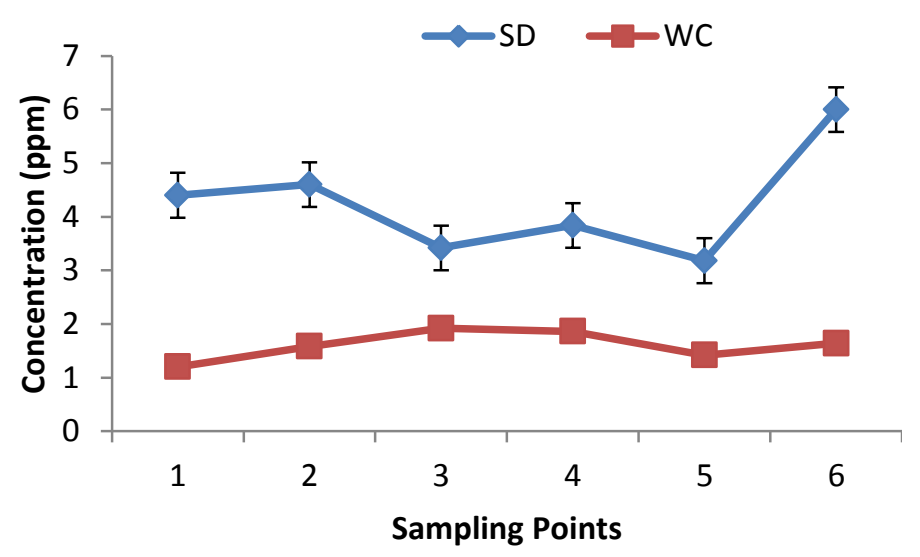

Figure 5. Spatial variations in levels of nickel in sediments and water columns of Otamiri River, Owerri. 


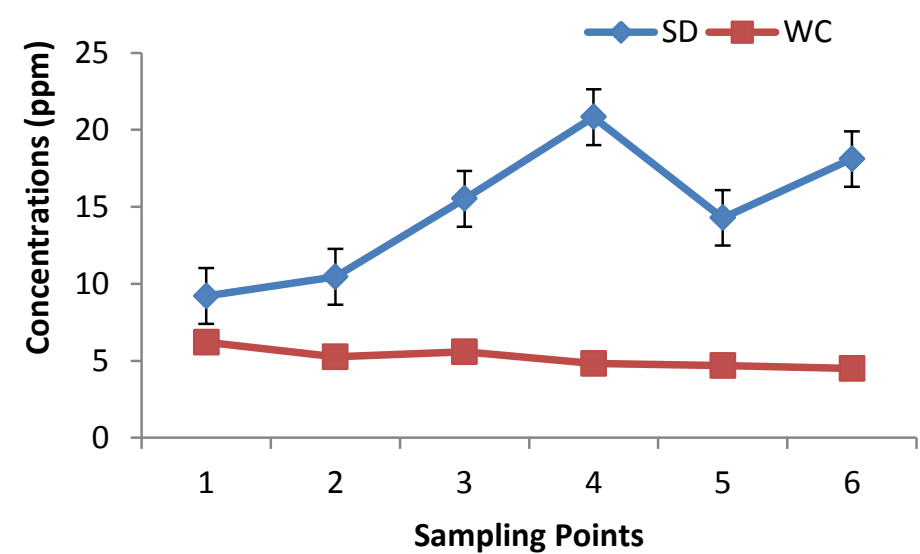

Figure 6. Spatial variations in levels of zinc in sediments and water columns of Otamiri River, Owerri.

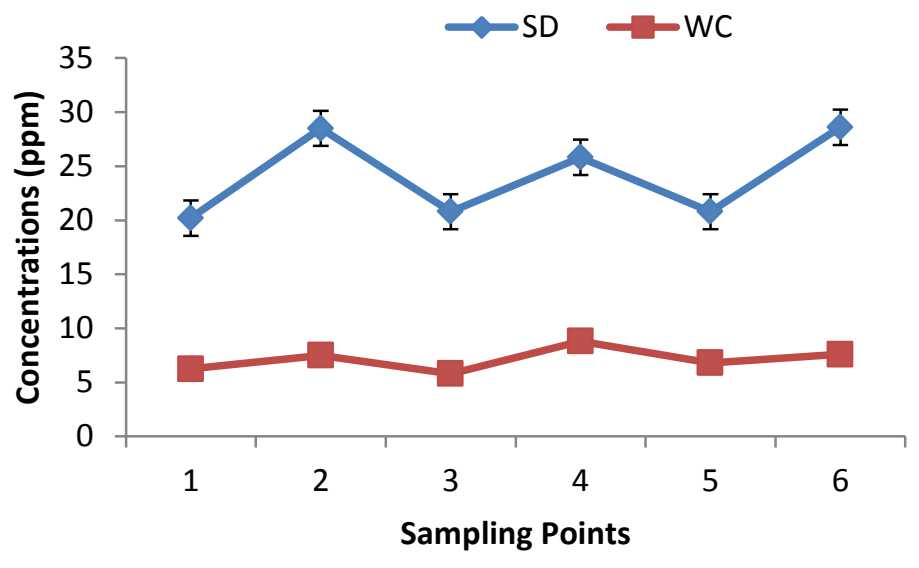

Figure 7. Spatial variations in levels of iron in sediments and water columns of Otamiri River, Owerri.

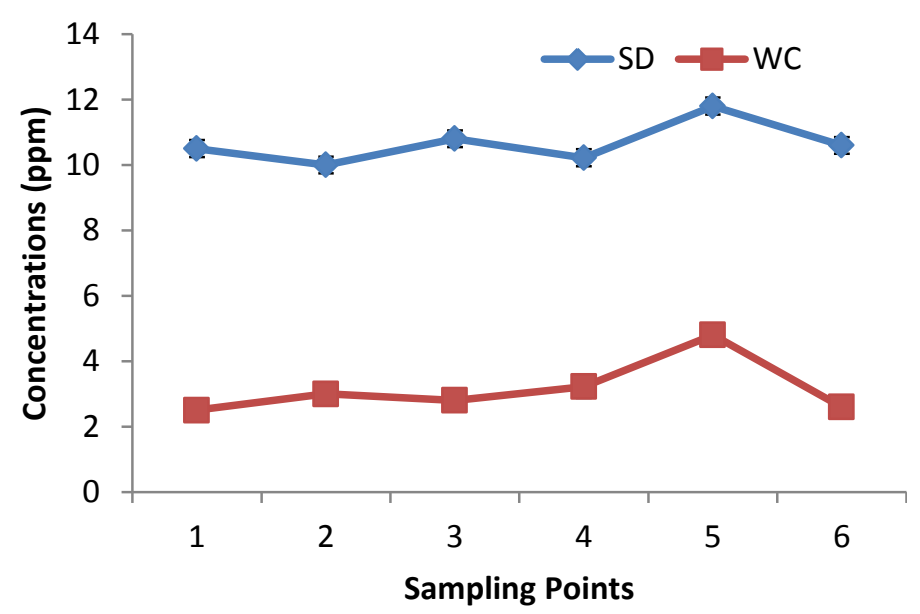

Figure 8. Spatial variations in levels of manganese in sediments and water columns of Otamiri River, Owerri.

Table 1. Index of geoaccumulation $\left(\mathrm{I}_{\mathrm{geo}}\right)$, accumulation factor (AF) and pond recovery capacity (PRC) of mine ponds of the Otamiri River in Owerri.

\begin{tabular}{c|cccc}
\hline S/No & $\begin{array}{c}\text { Heavy } \\
\text { Metals }\end{array}$ & I $_{\text {geo }}$ & AF & PRC (\%) \\
\hline 1 & $\mathrm{~Pb}$ & 3.214 & 0.987 & -1.373 \\
2 & $\mathrm{Hg}$ & 0.000 & 0.000 & 0.000 \\
3 & $\mathrm{As}$ & 0.000 & 0.000 & 0.000 \\
4 & $\mathrm{Cd}$ & 1.649 & 1.179 & 15.165 \\
5 & $\mathrm{Cu}$ & 4.743 & 1.032 & 3.052 \\
6 & $\mathrm{Ni}$ & 2.483 & 1.048 & 4.608 \\
7 & $\mathrm{Zn}$ & 4.932 & 1.513 & 33.891 \\
8 & $\mathrm{Fe}$ & 5.959 & 1.082 & 7.604 \\
9 & $\mathrm{Mn}$ & 4.326 & 1.042 & 4.047 \\
10 & $\mathrm{Co}$ & 0.000 & 0.000 & 0.000 \\
\hline
\end{tabular}




\section{DISCUSSION}

The levels of all the detected heavy metals exceeded regulatory limits set by the Federal Ministry of Environment (Nigeria, 2001) and the National Environmental Standards and Regulations Enforcement Agency (NESREA, 2011) in Nigeria. This portends toxicity risks to aquatic biota through possible bioaccumulation and ultimately to human consumers of the resources. Accordingly, Braga (2002) stated that water contamination prevents its use for human consumption. Apparently, lentic zones such as these ponds could serve as brooding grounds for aquatic organisms and elevated contaminations with these recalcitrant pollutants could expose the organisms, especially juveniles, to toxicity. Therefore, when evaluating pollution and the quality of aquatic systems, it is important to take into consideration possible contamination by sediments deposited around ponds, apart from detecting contaminants that do not remain soluble after launched in water column (Lima, 2001).

The higher levels of heavy metals in the sediments than in the water columns rightly indicate the repository role of sediments in aquatic environments (Axtmann and Luoma, 1991; Ogbuagu et al., 2011; Baggio and Heinrich, 2012).

The significantly variant levels of the pollutants between the actively mined and derelict ponds indicate the effects of perturbations created by in-stream mining. The higher concentrations of $\mathrm{Pb}, \mathrm{Cd}, \mathrm{Cu}, \mathrm{Ni}$ and $\mathrm{Zn}$ in the water columns and of $\mathrm{Pb}, \mathrm{Cd}$ and $\mathrm{Cu}$ in the sediments of the derelict rather than the actively mined ponds reflects the ceasing of removal of the metals through sediment excavations during mining. However, the higher concentrations of $\mathrm{Fe}$ and $\mathrm{Mn}$ in the water columns and of $\mathrm{Ni}, \mathrm{Zn}, \mathrm{Fe}$ and $\mathrm{Mn}$ in the sediments of the actively mined than the derelict ponds suggests that these pollutants are more abundant in sediments and so get re-suspended in the water columns (Fe \& Mn) during active sediment excavations. Baggio and Heinrich (2012) further showed that sediments act as carriers of potential pollution sources, such as heavy metals, that are not permanently fixed and that they can be rearranged into the water column by changing environmental conditions, some of which are triggered by anthropogenic activities.

Going by the sediment quality of $\mathrm{I}_{\text {geo }}$ classifications (Müller, 1979), the actively mined ponds were extremely contaminated with $\mathrm{Fe}$, strongly to extremely contaminated with $\mathrm{Cu}, \mathrm{Zn}$ and $\mathrm{Mn}$, strongly contaminated with $\mathrm{Pb}$, moderately to strongly contaminated with $\mathrm{Ni}$ and moderately contaminated with $\mathrm{Cd}$. Reference to the two accumulation indices used indicates consistency in accumulations (though not in order) of all the detectable metals in sediments of the ponds. Thus, the major contaminants of ecological concern were $\mathrm{Fe}, \mathrm{Zn}, \mathrm{Cu}$ and $\mathrm{Cd}$. The least accumulating metals were $\mathrm{Cu}, \mathrm{Pb}, \mathrm{Ni}$ and $\mathrm{Cd}$.

Conversely, the sediments showed very low recoveries of less than $50 \%$ from pollutant loadings, and the most of these recoveries were in $\mathrm{Zn}, \mathrm{Cd}$ and $\mathrm{Fe}$, with $\mathrm{Pb}$ showing even deficit recovery. This implies recalcitrance in heavy metals pollution and further implicates $\mathrm{Pb}$ as the most persistent pollutant in sediments, especially in the derelict ponds. Though Xavier (2004) had stated that soil has the ability to immobilize and depurate most of the impurities deposited on it by acting as a filter for pollutants, in the case of multiple sources of contaminants resulting from anthropogenic impacts, this filtering capacity and self-purification could be compromised.

\section{CONCLUSION}

The levels of the detectable heavy metals were all above regulatory limits, with significantly higher concentrations in sediments than in water columns and variant levels between the actively mined and derelict sand mine ponds. $\mathrm{Hg}$, As and Co were undetected in both water columns and sediments of the mine ponds. Fe and $\mathrm{Zn}$ exhibited the highest 
geoaccumulation index and accumulation factor, while $\mathrm{Cd}$ and $\mathrm{Pb}$ exhibited the least geoaccumulation index and accumulation factor, respectively. However, the metals showed very low recoveries, especially in the derelict pond.

Sand mining activities appeared to be related to the presence and levels of heavy metals, as well as the self-purification capacity of the mine ponds.

\section{REFERENCES}

AMERICAN PUBLIC HEALTH ASSOCIATION- APHA; AMERICAN WATER WORKS ASSOCIATION - AWWA; WATER ENVIRONMENT FEDERATION - WEF. Standard methods for examination of water and wastewater. 20th ed. Washington DC, 1998.

AXTMANN, E. V.; LUOMA, S. N. Large-scale distribution of metal contamination in the fine-grained sediments of the Clark Fork River, Montana, U.S.A. Applied Geochemistry, v. 6, p. 75-88, 1991. http://dx.doi.org/10.1016/0883-2927(91)90064-V

BAGGIO, H. F. Contribuições naturais e antropogênicas para a concentração e distribuição de metais pesados em sedimento de corrente na bacia do Rio do Formoso, município de Buritizeiro. 2008. 234f. Tese (Doutorado) - Instituto de Geociências, Universidade Federal de Minas Gerais, Belo Horizonte, 2008.

BAGGIO, H.; HEINRICH, H. Natural and anthropogenic contributions to concentration and distribution of heavy metals in surface water and in stream sediments in the Formoso River, Buritizeiro municipality-Minas Gerais State, Brazil. Comunicações Geológicas, v. 99, n. 2, p. 71-78, 2012.

BRAGA, L. L. Avaliação do impacto ambiental da usina de beneficiamento de Fe e Si, Várzea da Palma, MG, Brasil - distribuição e transporte dos contaminantes. 2002. 81f. Dissertação (Mestrado em Geologia Ambiental) - Instituto de Geociências, Universidade Federal de Minas Gerais, Belo Horizonte, 2002.

ERNESTOVA, L. S.; SEMENOVA, I. V. The self-purification capacity of natural water as an indicator of the ecological state of a water body. Water Resources, v. 21, n. 2, p. 146-150, 1994.

FAKAYODE, S. O. Impact assessment of industrial effluent on water quality of the receiving Alaro River in Ibadan, Nigeria. Ajeam-Ragee, v. 10, p. 1-13, 2005.

LIMA, M. J. Avaliação de metais e elementos-traço em águas e sedimentos das bacias hidrográficas dos rios Mogi-Guaçu e Prado, São Paulo. 2001. 210f. Tese (Mestrado) - Instituto de Pesquisas Energéticas e Nucleares, São Paulo, 2001.

MEURER, E. J.; BASSANI, C. A.; SELBACH, P. A. Poluentes dos solos e do ambiente. In: MEURER, E. J. Fundamentos de química dos solos. Porto Alegre: Gênesis, 2000. P. 151-174.

MÜLLER, G. Schwermetalle in den sedimenten des Rheins-Veränderungen seit 1971. Umschau, v. 79, p. 778-783, 1979.

NATIONAL ENVIRONMENTAL STANDARDS AND REGULATIONS ENFORCEMENT AGENCY - NESREA. National environmental (Surface and groundwater quality control) regulations. Federal Republic of Nigeria Official Gazette, v. 98, n. 49, 2011. 
NIGERIA. Ministry of Environment - FME. National guidelines and standards for water quality in Nigeria. Rishab Printing Press Production, 2001. p. 114.

OGBUAGU, D. H.; NJOKU, J. D.; AYOADE, A. A. Trends in macrobenthal biotypes of Imo River in a Nigerian Delta region. Journal of Biodiversity and Environmental Sciences (JBES), v. 1, n. 4, p. 22-28, 2011.

ONWEREMADU, E. U.; AKAMIGBO, F.; IGWE, C. A. Soil quality morphological index in relation to organic carbon content of soils in southwestern Nigeria. Trends in Applied Science Research, v. 3, n. 1, p. 76-82, 2008.

VICTOR, S.; AC-CHUKWUOCHA, N. B.; OGBUAGU, D. H. Trace metals availability in soils of watershed in relation to land use in Owerri, southeastern Nigeria. Journal of Science and Sustainability, v. 3, p. 3-12, 2011.

XAVIER, L. L. Análise de risco ambiental em cenários de contaminação de solos: uma avaliação metodologica comparativa. 2004. 250f. Dissertação (Mestrado) Universidade Federal de Minas Gerais, Belo Horizonte, 2004. 


Ambiente \& Água - An Interdisciplinary Journal of Applied Science
ISSN 1980-993X - doi:10.4136/1980-993X
www.ambi-agua.net
E-mail: ambi-agua@agro.unitau.br

\title{
Hidrogeologia e hidroquímica dos aquíferos fraturados associados às rochas vulcânicas ácidas no Município de Carlos Barbosa (RS)
}

\author{
doi: 10.4136/ambi-agua.1270
}

Received: 01 Jan. 2014; Accepted: 09 Mar. 2014

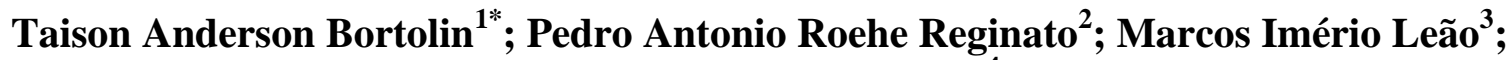 \\ Vania Elisabete Schneider ${ }^{4}$

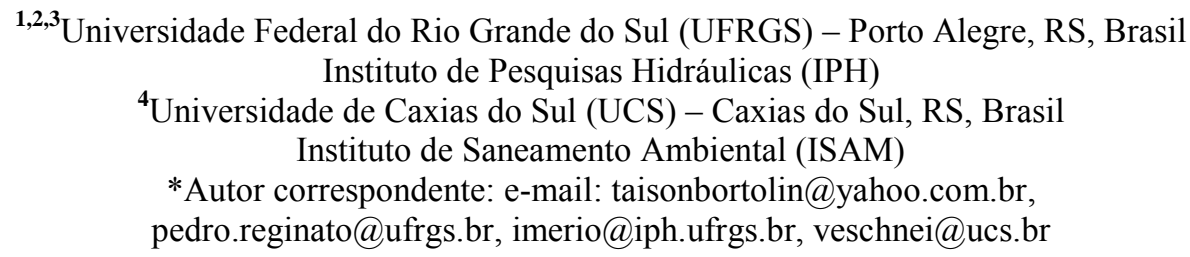

\section{RESUMO}

Este artigo apresenta o estudo hidrogeológico e hidroquímico dos aquíferos fraturados que formam o Sistema Aquífero Serra Geral (SASG) e que estão associados a rochas vulcânicas ácidas. A região de estudo compreende parte da área do município de Carlos Barbosa, localizado na região nordeste do estado do Rio Grande do Sul. O estudo foi desenvolvido a partir do inventário e cadastramento de poços tubulares existentes na região, do levantamento e interpretação de dados geológicos e hidrogeológicos, além da coleta e análise de amostras de água de poços tubulares que estão em funcionamento e são utilizados pela companhia de abastecimento CORSAN. Os resultados obtidos permitiram evidenciar que a maioria dos poços apresenta profundidade de até 150 metros com vazões médias que variam de 5 a $20 \mathrm{~m}^{3} \mathrm{~h}^{-1}$, localizados em zonas de média e alta densidade de fraturas, as quais possuem orientação preferencial para noroeste. Quanto à hidroquímica, as águas que circulam por esses aquíferos são do tipo bicarbonatadas cálcicas ou magnesianas, predominando as águas bicarbonatadas mistas e cálcicas, apresentando pequenas variações quanto à concentração dos íons e suas razões iônicas. Essas características hidroquímicas são típicas de águas que circulam por estruturas de rochas vulcânicas ácidas e indicam um baixo tempo de residência, sendo as concentrações variáveis com as profundidades das entradas da água.

Palavras-chave: caracterização hidrogeoquímica, sistema aquífero Serra Geral, águas subterrâneas.

\section{Hydrogeology and hydrochemistry of fractured aquifers associated with acidic volcanic rocks in the city of Carlos Barbosa (RS)}

\begin{abstract}
This paper presents the hydro-geological and hydro-chemical study of fractured aquifers that form the Serra Geral Aquifer System (SASG) associated with acid volcanic rocks. The study area comprises part of the city of Carlos Barbosa, located in the northeast region of Rio Grande do Sul State. The study was developed based on the inventory and registration of existing wells in the region, the survey and interpretation of geological and hydro-geological
\end{abstract}


data, in addition to the collection and analysis of samples from wells that are in operation and used by the CORSAN water supply company. The results highlighted that most wells have depth up to 150 meters with flow rates average ranging from 5 to $20 \mathrm{~m}^{3} \mathrm{~h}^{-1}$, located in areas with medium and high density of fractures, which have preferential orientation to the northwest. As for hydro-chemistry, water circulating through these aquifers is the calcic or magnesium bicarbonate type, predominantly mixed and calcic bicarbonate waters, with minor variations in the concentration of ions and their ionic reasons. These hydro-chemical characteristics are typical of waters that circulate within structures and acid volcanic rocks indicate a low residence, with concentrations varying with water input depths.

Keywords: hydro-geochemical characterization, Serra Geral aquifer system, groundwater.

\section{INTRODUÇÃO}

Na região nordeste do estado do Rio Grande do Sul, os recursos hídricos subterrâneos têm grande importância, pois na maioria das situações correspondem à principal fonte de água disponível para abastecimento humano ou uso no desenvolvimento de atividades industriais ou agrícolas.

Nessa região as águas subterrâneas estão associadas a dois tipos principais de aquíferos: o livre (freático) e o fraturado (Reginato, 2003). O primeiro aquífero fornece volumes reduzidos de água, sendo mais utilizado pela população rural, que capta suas águas através de poços escavados ou fontes. O segundo aquífero fornece maiores volumes e água com melhor qualidade, sendo utilizado para abastecimento da população urbana da maioria dos municípios, bem como de algumas comunidades rurais, através de poços tubulares comunitários.

Este sistema aquífero ocupa uma extensa área no nordeste do planalto rio-grandense, e está associado com as rochas vulcânicas ácidas e básicas que formam a Unidade Hidroestratigráfica Serra Geral. As litologias dessa unidade são representadas predominantemente por riolitos, riodacitos e, em menor proporção, basaltos fraturados. A capacidade específica é inferior a $0,5 \mathrm{~m}^{3} / \mathrm{h} / \mathrm{m}$, entretanto, excepcionalmente em áreas mais fraturadas ou com arenitos na base do sistema, podem ser encontrados valores superiores a $2 \mathrm{~m} 3 / \mathrm{h} / \mathrm{m}$ (Machado e Freitas, 2005).

As águas que circulam por esses aquíferos apresentam características hidroquímicas e qualidade variada. Essa diferenciação depende do tipo de aquífero, da litologia, da recarga, do grau de confinamento, da vulnerabilidade e do uso e ocupação do solo (Reginato, 2003; Reginato et al., 2012).

Este artigo objetiva apresentar o estudo hidrogeológico e hidroquímico das águas subterrâneas do Sistema Aquífero Serra Geral associado às rochas vulcânicas ácidas, na área abrangida pelo município de Carlos Barbosa, inserido na região nordeste do Estado do Rio Grande do Sul.

\section{2. ÁREA DE ESTUDO}

A área de estudo está localizada na região nordeste do Estado do Rio Grande do Sul, mais precisamente na zona urbana do município de Carlos Barbosa, inserida na região do planalto do estado, conforme apresenta o mapa da Figura 1. O município está localizado a $676 \mathrm{~m}$ acima do nível do mar, sendo a altitude da sede de $618 \mathrm{~m}$. Encontra-se entre as coordenadas geográficas $29^{\circ} 18^{\prime}$ de Latitude Sul e $51^{\circ} 30^{\prime}$ de Longitude Oeste, sendo abastecido em sua totalidade por águas subterrâneas. 


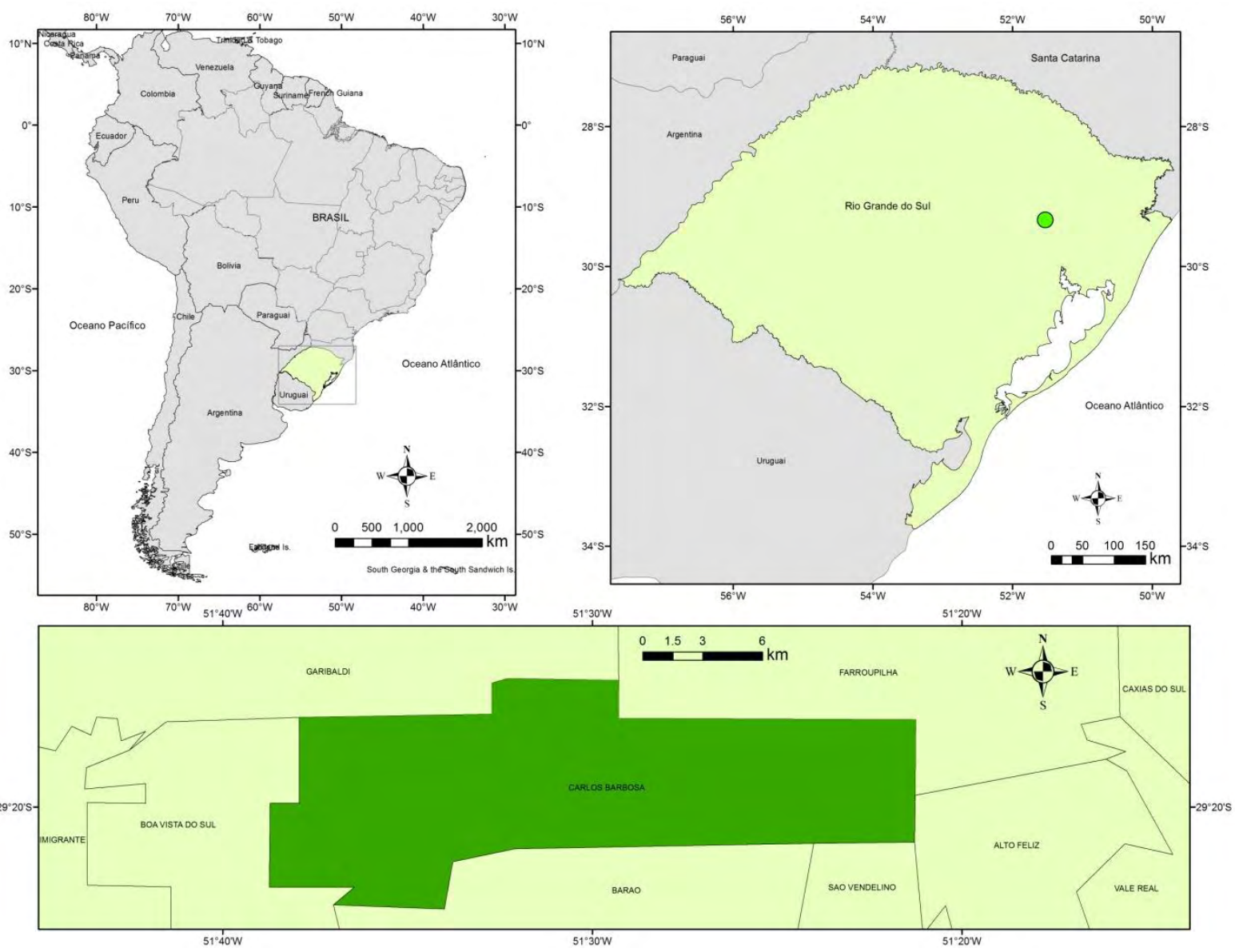

Figura 1. Localização da área de estudo.

\section{MATERIAL E MÉTODOS}

Para o desenvolvimento desse estudo foram realizados o inventário e cadastramento de poços tubulares existentes na região, o levantamento e interpretação de dados geológicos e hidrogeológicos, além da coleta e análise de amostras de água de poços tubulares.

O inventário e cadastramento dos poços tubulares foi realizado através da consulta ao Sistema de Informações de Águas Subterrâneas (SIAGAS-CPRM), à Companhia Riograndense de Abastecimento (CORSAN) e por meio de levantamentos de campo. Os dados geológicos e hidrogeológicos, tais como tipo de rocha e suas características, nível estático dos poços, nível dinâmico, parâmetros hidrodinâmicos (transmissividade e capacidade específica) e vazão, foram utilizados na elaboração de um banco de dados criado com uso do programa Visual Poços Pro (Schlumberger Water Services, 1998).

A caracterização estrutural foi realizada com base na interpretação de produtos de sensoriamento remoto (imagens de radar e fotografias aéreas) e de modelos digitais de elevação do terreno. Esses produtos foram utilizados na identificação dos lineamentos morfoestruturais existentes na região, sendo realizada a interpretação desses lineamentos visando identificar parâmetros como orientação e densidade. Também foram realizadas atividades de campo visando a identificação dos diferentes tipos de estruturas e suas características geométricas. A avaliação da existência de controle estrutural sobre os poços tubulares foi realizada através de mapeamento utilizando o programa ArGis 10.2 (ESRI, 2013).

Para composição do mapa de densidade de fraturas, utilizou-se o método de densidade de Kernel, disponível no referido programa. Para isso a região abrangida foi dividida em células 
com dimensões iguais de $10000 \mathrm{~m}^{2}$, onde foi contabilizado o número de fraturas que estavam inseridas em cada célula. Com isso foi possível gerar um mapa de densidade de fraturas contendo a delimitação de regiões com baixa (0-1 fratura), média (1 a 3 fraturas) e alta (acima de 3 fraturas).

A caracterização hidroquímica foi feita com base na interpretação dos resultados de análises físico-químicas realizadas em amostras de água subterrânea coletadas de poços tubulares. A seleção dos poços foi realizada com base nas informações geológicas, hidrogeológicas e construtivas disponíveis para os poços cadastrados, sendo que os poços selecionados deveriam captar água de aquíferos associados às rochas vulcânicas ácidas.

Assim, foram selecionados 12 poços tubulares pertencentes a Companhia Riograndense de Saneamento (CORSAN), onde foram realizadas duas coletas de amostras de água subterrânea nos meses de abril e julho de 2013. Para coleta, utilizou-se o sistema de bombeamento do poço, sendo a bomba acionada e mantida ligada, por pelo menos 10 minutos. Após esse tempo, realizou-se a coleta das amostras de água, na saída da tubulação ligada à bomba. Para cada ponto foram coletadas amostras e enviadas para análise laboratorial dos parâmetros ferro, bicarbonatos, manganês, fluoretos, alcalinidade, cloreto, sulfato, cálcio, magnésio, sódio e potássio. Parâmetros como $\mathrm{pH}$, condutividade e temperatura foram amostrados em campo, utilizando uma sonda multiparâmetros Horiba U50.

A avaliação dos relatórios analíticos foi feita com base na seleção dos parâmetros analisados e no erro cometido nas análises (Cálculo do Erro pelo Balanço Iônico). Os resultados das análises foram utilizados na montagem de um banco de dados e na elaboração de diagramas Piper (1944), Schoeller (1935) e Stiff (1951) com o uso do programa AcquaChem 5.1 (Schlumberger Water Services, 2008).

Como forma de auxiliar na determinação das relações entre as litologias constituintes dos aquíferos e o quimismo das águas subterrâneas, foram calculadas as razões iônicas ou índices hidrogeoquímicos (Hem, 1985), que podem indicar um relacionamento certo entre o litotipo e a água. As variações das razões iônicas de $\mathrm{Mg}^{+2} / \mathrm{Ca}^{+2}, \mathrm{~K}^{+} / \mathrm{Na}^{+}, \mathrm{Na}^{+} / \mathrm{Ca}^{+2}, \mathrm{Na}^{+} / \mathrm{Ca}^{+2}+\mathrm{Mg}^{+2}$, $\mathrm{HCO}_{3}{ }^{-} / \mathrm{Ca}^{+2}$ são indicativos da preponderância de determinado elemento sobre os outros elementos, em função, por exemplo, da composição mineralógica das rochas do sistema aquífero.

\section{RESULTADOS E DISCUSSÃO}

\subsection{Caracterização Hidrogeológica}

$\mathrm{Na}$ região de estudo há ocorrência de dois tipos principais de litologias: basaltos do tipo Gramado e vulcânicas ácidas do tipo Palmas/Caxias (Roisenberg e Viero, 2002). Com base nos levantamentos de campo pode-se identificar que em altitudes até 500 metros são encontradas rochas basálticas. Acima de 500 metros foram identificados 5 derrames de rochas ácidas, sendo os riolitos e o riodacitos os litotipos principais. Além disso, observou-se que os derrames ácidos apresentam disjunção horizontal e zonas vesiculares a amigdaloides. As amigdalas em geral, são preenchidas por quartzo e calcita.

A partir do levantamento de dados de fontes secundárias como SIAGAS e CORSAN foram identificados 137 poços perfurados no município de Carlos Barbosa. Desses 137 poços, 76 poços possuíam dados de nível estático, 57 de capacidade específica, 74 de vazão e 50 poços possuíam o número e a profundidade de entradas de água, os quais foram utilizados na caracterização hidrogeológica. Além disso, 12 poços localizados em rochas ácidas foram utilizados para coleta de amostras de água subterrânea a fim de realizar a caracterização hidroquímica (Figura 2). 


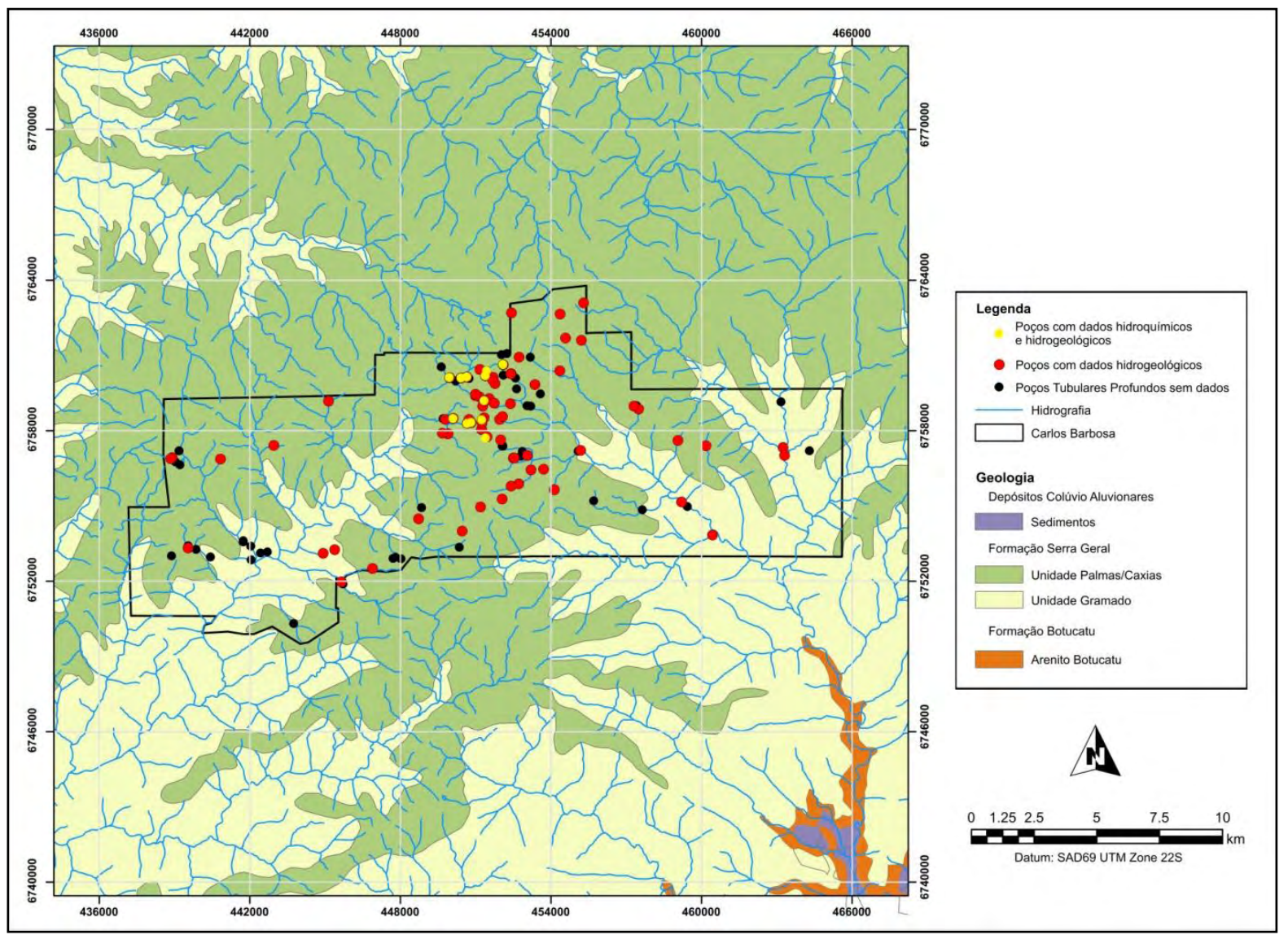

Figura 2. Localização dos poços de amostragem.

A análise hidrogeológica dos poços que possuíam dados (Tabela 1) permitiu identificar que, a maioria das captações tem profundidade entre 100 e 150 metros (39\%), seguida por profundidades entre 50 e 100 metros (34\%). Esses dados demonstram que os poços existentes na região, captam água de fraturas que estão localizadas no intervalo entre 50 e 150 metros.

Tabela 1. Distribuição percentual dos principais dados e parâmetros hidrodinâmicos obtidos da interpretação de dados dos poços tubulares.

\begin{tabular}{|c|c|c|c|c|}
\hline \multirow{2}{*}{$\begin{array}{c}\text { Dados e Parâmetros } \\
\text { Profundidade dos Poços (m) }\end{array}$} & \multicolumn{4}{|c|}{ Resultados } \\
\hline & 0 a $50(3 \%)$ & 50 a $100(34 \%)$ & 100 a $150(39 \%)$ & $>150(24 \%)$ \\
\hline Número de Entradas de Água & $1(36 \%)$ & $2(26 \%)$ & $3(18 \%)$ & $>3(20 \%)$ \\
\hline $\begin{array}{l}\text { Profundidade das Entradas de } \\
\text { Água (m) }\end{array}$ & 0 a $20(21 \%)$ & 20 a $50(26 \%)$ & 50 a $100(37 \%)$ & $>100(16 \%)$ \\
\hline Nível Estático (m) & 0 a $5(41 \%)$ & 5 a $10(18 \%)$ & 10 a $20(14 \%)$ & $>20(26 \%)$ \\
\hline $\begin{array}{l}\text { Capacidade Específica } \\
\left(\mathrm{q}-\mathrm{m}^{3} / \mathrm{h} / \mathrm{m}\right)\end{array}$ & 0 a $0,3(42 \%)$ & 0,3 a $0,5(19 \%)$ & 0,5 a $1,0(23 \%)$ & $>1,0(16 \%)$ \\
\hline Transmissividade $\left(\mathrm{m}^{2} / \mathrm{h}\right)$ & 0 a $0,1(27 \%)$ & 0,1 a $0,5(42 \%)$ & 0,5 a $1(15 \%)$ & $>1(15 \%)$ \\
\hline Vazão $\left(\mathrm{m}^{3} / \mathrm{h}\right)$ & 0 a $5(26 \%)$ & 5 a $10(22 \%)$ & 10 a $20(32 \%)$ & $>20(20 \%)$ \\
\hline
\end{tabular}


Identificou-se também que a maior parte dos poços possui de 1 a 3 entradas de água (80\%), localizadas entorno de 50 a 100 metros de profundidade (37\%). Alguns poços possuem entradas até 20 metros $(21 \%)$ e $26 \%$ dos poços possuem entradas de água entre 20 e 50 metros.

O nível estático (NE) está associado a diferentes profundidades, sendo na maior parte dos casos, localizado entre 0 e 5 metros de profundidade (41\%). Isso evidencia que o aquífero fraturado, embora tenha entradas de água localizadas em diferentes níveis, possui um comportamento semelhante a aquíferos confinados ou semi-confinados. Dessa forma, a água subterrânea presente no aquífero, encontra-se sob pressão e, após a perfuração, tende a subir além da entrada de água.

Os cálculos hidrogeológicos com as informações dos testes de vazão de poços confirmam a baixa transmissividade, na maioria das vezes, muito baixas, sendo que a maioria dos poços apresentam valores no intervalo entre 0,1 e $0,5 \mathrm{~m}^{2} \mathrm{~h}^{-1}$, seguido por valores de até $0,1 \mathrm{~m}^{2} \mathrm{~h}^{-1}$ (42\%), variação típica de aquíferos fraturados (anisotrópicos).

A capacidade específica analisada indicou grande variação, ocorrendo na maior parte dos casos valores que estão no intervalo de 0 e $0,3 \mathrm{~m}^{3} / \mathrm{h} / \mathrm{m}(42 \%)$, seguidos por valores entre 0,5 a $1 \mathrm{~m}^{3} / \mathrm{h} / \mathrm{m}(23 \%)$ e por valores entre 0,3 a $0,5 \mathrm{~m}^{3} / \mathrm{h} / \mathrm{m}(19 \%)$, variabilidade condizente com o tipo de aquífero (fraturado), que por sua vez apresenta uma forte anisotropia.

Outro parâmetro analisado correspondeu à vazão, que apresentou na maioria dos poços analisados um valor entre 10 a $20 \mathrm{~m}^{3} \mathrm{~h}^{-1}(32 \%)$, seguida por uma vazão inferior a $5 \mathrm{~m}^{3} \mathrm{~h}^{-1}$ (26\%). Dependendo da localização do poço em relação ao lineamento, bem como da orientação do lineamento (nordeste ou noroeste), haverá diferenças significativas na vazão. Além disso, fatores relacionados com o projeto e a perfuração dos poços como profundidade, diâmetro, captação de outros aquíferos como o Sistema Aquífero Guarani, bem como o número de entradas de água, também têm influência na vazão.

$\mathrm{Na}$ região, foram identificados 266 lineamentos, sendo em sua maioria de pequeno porte (até $10 \mathrm{~km}$ ) com orientação preferencial para noroeste (N0-10W; N20-30W; N40-50W e N60-70W) e a secundária, para nordeste (N30-50E), como mostra a Figura 3. A maioria dos poços encontra-se em zona de média a alta densidade de fraturas, região mais propícia a ser encontrado um volume maior de água.

O cruzamento dos dados dos poços tubulares com as estruturas permitiu identificar a existência de um controle estrutural que têm influência na capacidade específica e produção desses poços. Assim, poços que estão associados a lineamentos de orientação noroeste e, em regiões com mais alta densidade de lineamentos são os poços mais produtivos.

\subsection{Caracterização Hidroquímica}

As características físico-químicas das águas subterrâneas do Sistema Aquífero Serra Geral (SASG) possuem variações condicionadas pelas características geológicas e hidrogeológicas da região, o que pode ser evidenciada através da caracterização hidroquímica (Reginato e Strieder, 2004). A circulação das águas subterrâneas nesses aquíferos é condicionada pelo sistema de fraturas e pelas estruturas de resfriamento dos derrames de rochas vulcânicas. Assim, as águas circulam em diferentes níveis de profundidade, em diferentes condições de confinamento e podem apresentar características hidroquímicas variadas.

A classificação das águas subterrâneas das duas amostragens realizadas, com base no Diagrama de Piper (Figura 4), indicou a ocorrência de um único campo que é o das águas bicarbonatadas cálcicas ou magnesianas.

Pela análise dos cátions observa-se que essas águas são cálcicas ou mistas. A ocorrência desse tipo de água está de acordo com os estudos do sistema aquífero Serra Geral realizados por Mobus (1987), Fraga (1992), Hausman (1966; 1995), Bittencourt (2003), Machado e 
Freitas (2005) e estudos regionais realizados por Lisboa (1996), Betiollo (2006), Nanni (2008) e Reginato et al. (2013), sendo que a fonte dos elementos cálcio, magnésio e sódio está relacionada com os silicatos presentes nas diferentes rochas vulcânicas. Conforme Lisboa (1996) as águas que circulam no SASG tendem a apresentar uma relação onde o $\mathrm{Ca}>\mathrm{Mg}>\mathrm{Na}$ predomina e um enriquecimento de cálcio e magnésio do topo (rochas ácidas) para a base (rochas básicas).

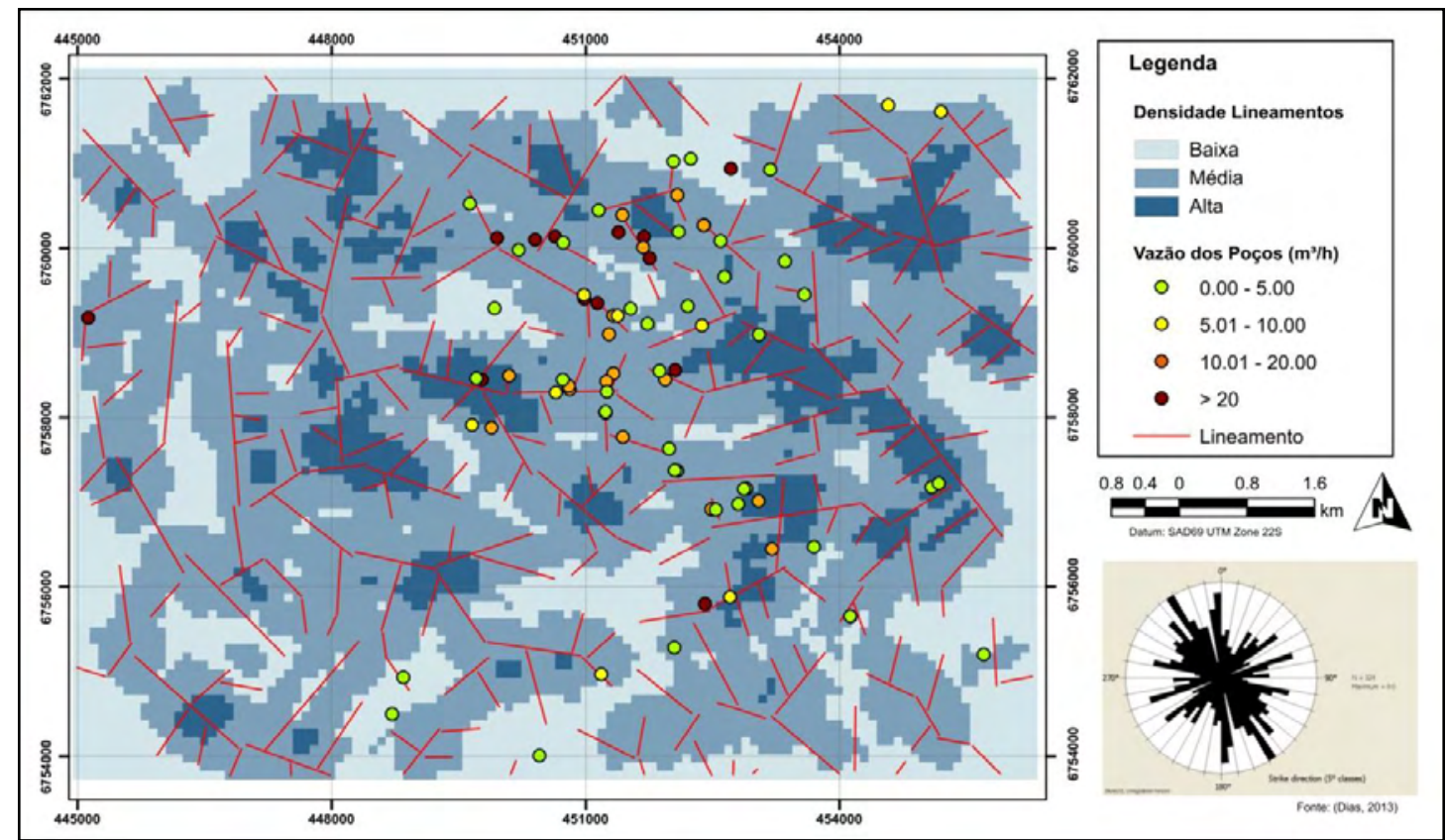

Figura 3. Mapa de densidade de fraturas e diagrama de roseta com as direções dos lineamentos.

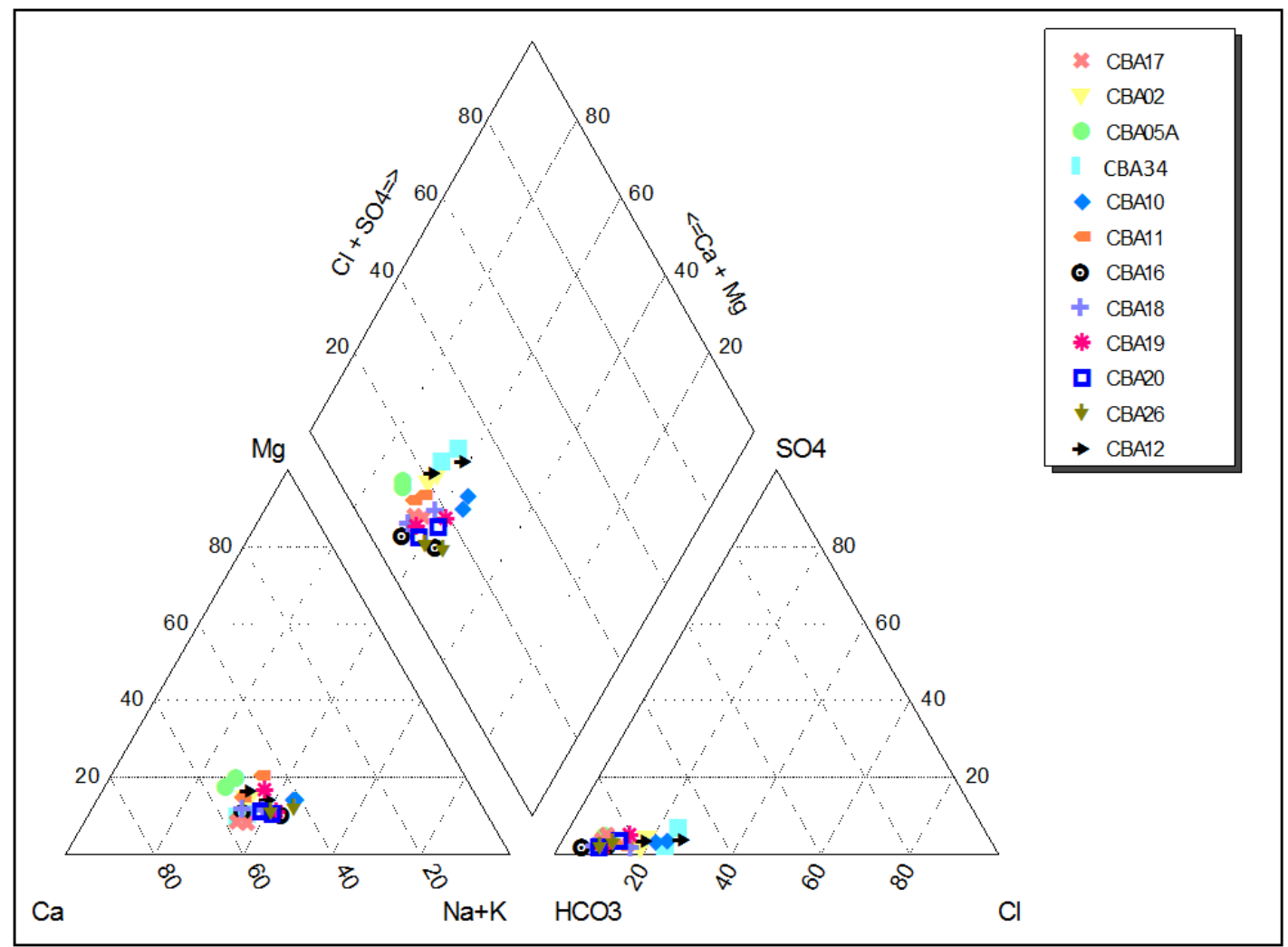

Figura 4. Diagrama Piper das amostras de água subterrânea do SASG. 
As águas bicarbonatadas cálcicas ou magnesianas analisadas apresentaram os resultados médios entre as duas campanhas realizadas apresentados na Tabela 2.

Tabela 2. Valores médios dos parâmetros analisados das duas amostragens realizadas.

\begin{tabular}{|c|c|c|c|c|c|c|c|c|c|c|c|c|}
\hline Poço & CBA02 & CBA05A & CBA10 & CBA11 & CBA12 & CBA16 & CBA17 & CBA18 & CBA19 & CBA20 & CBA26 & CBA34 \\
\hline Temp $\left({ }^{\circ} \mathrm{C}\right)$ & 17,84 & 18,14 & 17,80 & 17,85 & 17,91 & 18,41 & 18,28 & 18,01 & 18,10 & 17,69 & 17,56 & 17,72 \\
\hline $\mathrm{pH}$ & 6,23 & 6,07 & 5,52 & 5,73 & 5,80 & 6,19 & 6,18 & 6,04 & 6,08 & 6,13 & 6,17 & 6,22 \\
\hline Cond. $\left(\mathrm{uS} \mathrm{cm}^{-1}\right)$ & 196,00 & 159,00 & 108,50 & 141,50 & 110,50 & 145,50 & 189,00 & 148,50 & 150,00 & 141,50 & 102,50 & 168,50 \\
\hline Alctotal $\left(\mathrm{mg} \mathrm{L}^{-1}\right)$ & 60,64 & 61,40 & 25,57 & 39,84 & 24,59 & 60,88 & 77,15 & 54,62 & 56,35 & 57,35 & 41,51 & 46,11 \\
\hline $\mathrm{HCO} 3\left(\mathrm{mg} \mathrm{L}^{-1}\right)$ & 74,42 & 74,55 & 31,12 & 50,65 & 29,87 & 74,10 & 94,40 & 66,31 & 69,25 & 70,00 & 49,73 & 56,13 \\
\hline $\mathrm{Ca}^{+2}\left(\mathrm{mg} \mathrm{L}^{-1}\right)$ & 20,63 & 17,38 & 8,69 & 11,69 & 9,46 & 15,45 & 21,90 & 14,95 & 14,64 & 14,89 & 9,96 & 17,71 \\
\hline $\mathrm{Cl}^{-}\left(\mathrm{mg} \mathrm{L}^{-1}\right)$ & 10,33 & 5,15 & 5,41 & 4,75 & 5,34 & 3,98 & 5,85 & 5,64 & 5,73 & 5,09 & 3,36 & 11,11 \\
\hline $\mathrm{F}^{-}\left(\mathrm{mg} \mathrm{L}^{-1}\right)$ & 0,51 & 0,56 & 0,86 & 0,54 & 0,49 & 0,95 & 0,85 & 0,59 & 0,37 & 0,70 & 0,90 & 0,54 \\
\hline $\mathrm{Fe}^{+2}\left(\mathrm{mg} \mathrm{L}^{-1}\right)$ & 0,06 & 0,06 & 0,06 & 0,06 & 0,06 & 0,07 & 0,06 & 0,06 & 0,06 & 0,06 & 0,06 & 0,06 \\
\hline $\mathrm{Mg}^{+2}\left(\mathrm{mg} \mathrm{L}^{-1}\right)$ & 3,55 & 3,58 & 1,74 & 2,54 & 1,76 & 1,88 & 1,86 & 1,96 & 2,55 & 1,90 & 1,48 & 1,92 \\
\hline $\mathrm{Mn}^{+2}\left(\mathrm{mg} \mathrm{L}^{-1}\right)$ & 0,04 & 0,04 & 0,04 & 0,04 & 0,04 & 0,18 & 0,04 & 0,04 & 0,04 & 0,04 & 0,04 & 0,04 \\
\hline $\mathrm{K}^{+}\left(\mathrm{mg} \mathrm{L}^{-1}\right)$ & 4,54 & 1,01 & 5,32 & 3,33 & 3,25 & 2,65 & 1,09 & 2,13 & 3,94 & 2,22 & 1,96 & 2,74 \\
\hline $\mathrm{Na}^{+}\left(\mathrm{mg} \mathrm{L}^{-1}\right)$ & 12,89 & 9,72 & 7,39 & 7,09 & 6,09 & 12,11 & 15,32 & 10,77 & 11,55 & 12,36 & 9,45 & 11,18 \\
\hline $\mathrm{SO}_{4}^{-2}\left(\mathrm{mg} \mathrm{L}^{-1}\right)$ & 2,00 & 2,50 & 1,00 & 1,00 & 1,00 & 1,00 & 3,50 & 1,00 & 2,00 & 1,50 & 1,00 & 2,50 \\
\hline $\operatorname{STD}\left(\mathrm{mg} \mathrm{L}^{-1}\right)$ & 127,50 & 131,50 & 70,50 & 77,50 & 72,00 & 94,50 & 123,00 & 98,50 & 97,50 & 92,00 & 67,00 & 109,50 \\
\hline
\end{tabular}

Em geral as águas do aquífero Serra Geral apresentam concentrações variáveis de cálcio, magnésio e sódio e, pequenas concentrações de cloretos e sulfatos. A concentração média de Cálcio de $14,78 \mathrm{mg} \mathrm{L}^{-1}$ está diretamente relacionada ao arcabouço químico-mineralógico do aquífero, pois reflete a remoção do cálcio dos plagioclásios e minerais ferromagnesianos dos basaltos. A solubilidade do $\mathrm{Ca}^{2+} \mathrm{em}$ águas naturais está vinculada à presença de espécies carbônicas dissolvidas como $\mathrm{H}_{2} \mathrm{CO}_{3}, \mathrm{HCO}_{3}$ e $\mathrm{CO}_{3}{ }^{2}$ (Mocelin e Ferreira, 2009).

A concentração de carbonatos e bicarbonatos são baixas, quando comparados por exemplo às águas do Sistema Aquífero Guarani. As águas Bicarbonatadas Cálcicas ou Magnesianas apresentam pH que varia de 5,5 a 6,3, sólidos totais dissolvidos (STD) de 70,5 a $131,5 \mathrm{mg} \mathrm{L}^{-1}, \mathrm{Na}^{+2}$ de 6,09 a $15,32 \mathrm{mg} \mathrm{L}^{-1}$, valores baixos, devido principalmente às entradas de água estarem associadas aos derrames de rochas vulcânicas ácidas. A dureza varia de 24 a $77 \mathrm{mg} \mathrm{L}^{-1}$ de $\mathrm{CaCO}_{3}$, com média de $70,6 \mathrm{mg} \mathrm{L}^{-1}$, o que caracteriza tais águas como pouco duras. Tais valores representam características de águas com pouco tempo de residência com recarga relacionada às precipitações pluviométricas através do manto de intemperismo (Hausmann, 1966; Lisboa, 1996).

Foram encontradas concentrações baixas de fluoreto que variam entre 0,37 e $0,95 \mathrm{mg} \mathrm{L}^{-1}$, valores que podem estar relacionados a mineralizações presentes nas fraturas. Nanni (2008) sugere que o enriquecimento de fluoreto no SASG decorre da combinação de recarga 
ascendente do Sistema Aquífero Guarani (SAG) em condições de alto confinamento e longo tempo de residência, situação não encontrada na região de estudo, uma vez que não há evidências de conexão com o SAG.

O ferro, comum nos óxidos de ferro (hematita e magnetita) e manganês que está intimamente associado com o ferro, apresentaram concentrações inferiores a $0,07 \mathrm{mg} \mathrm{L}^{-1} \mathrm{e}$ $0,32 \mathrm{mg} \mathrm{L}^{-1}$, respectivamente. As reduzidas concentrações de cloreto encontradas, em geral inferiores a $6 \mathrm{mg} \mathrm{L}^{-1}$, com exceção dos poços CBA02 e CBA34, que possuem concentrações superiores a $10 \mathrm{mg} \mathrm{L}^{-1}$, são explicadas devido às rochas ígneas serem pobres em cloretos.

A Figura 5 apresenta os diagramas de Stiff para algumas amostras realizadas, os quais mostram uma figura geométrica característica para a água analisada.

CBA17,30/04/2013

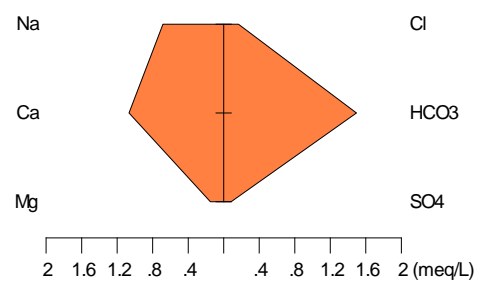

CBA12,24/07/2013

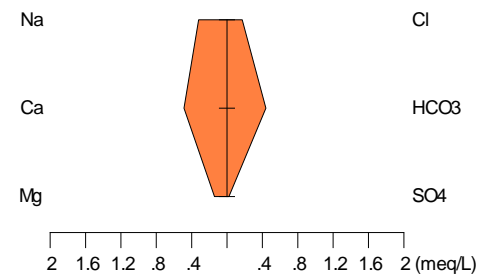

CBA10,24/07/2013

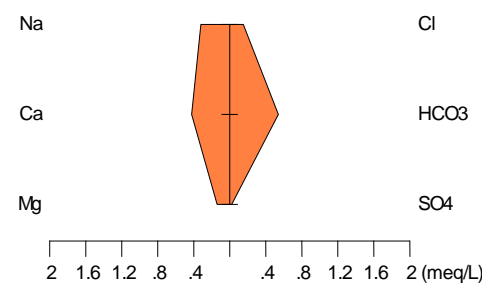

CBA11,30/04/2013

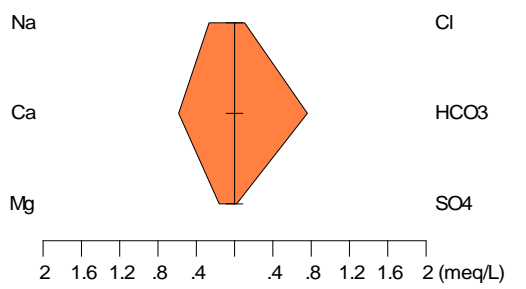

CBA05A,24/07/2013

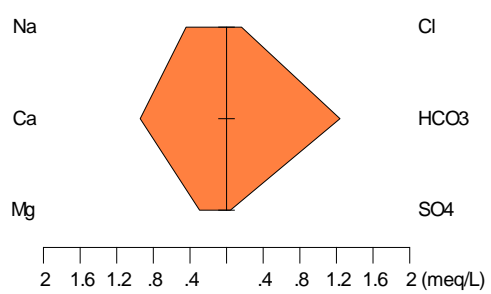

Figura 5. Geometrias observadas no Diagrama de Stiff das amostras de água subterrânea do SASG na área de estudo.

As amostras apresentam uma feição geométrica semelhante, com variação apenas na concentração dos íons. Os poços que apresentam maior concentração de cálcio também possuem maior concentração de carbonatos indicando um maior grau de dissolução da calcita, resultado de maior tempo de armazenamento no aquífero e maiores profundidades de armazenamento. Um exemplo desse comportamento é o poço CBA17, o qual possui entrada d'água localizada aos 101 metros.

A análise do diagrama de Schoeller (Figura 6) indica a existência de um comportamento hidroquímico geral com pequenas variações nas concentrações dos íons analisados. As variações mais significativas estão relacionadas às concentrações de magnésio, sódio, cloro e sulfato e podem ser explicadas pela ocorrência de diferentes entradas de água, localizadas em profundidades distintas de diferentes derrames de rochas vulcânicas ácidas. 


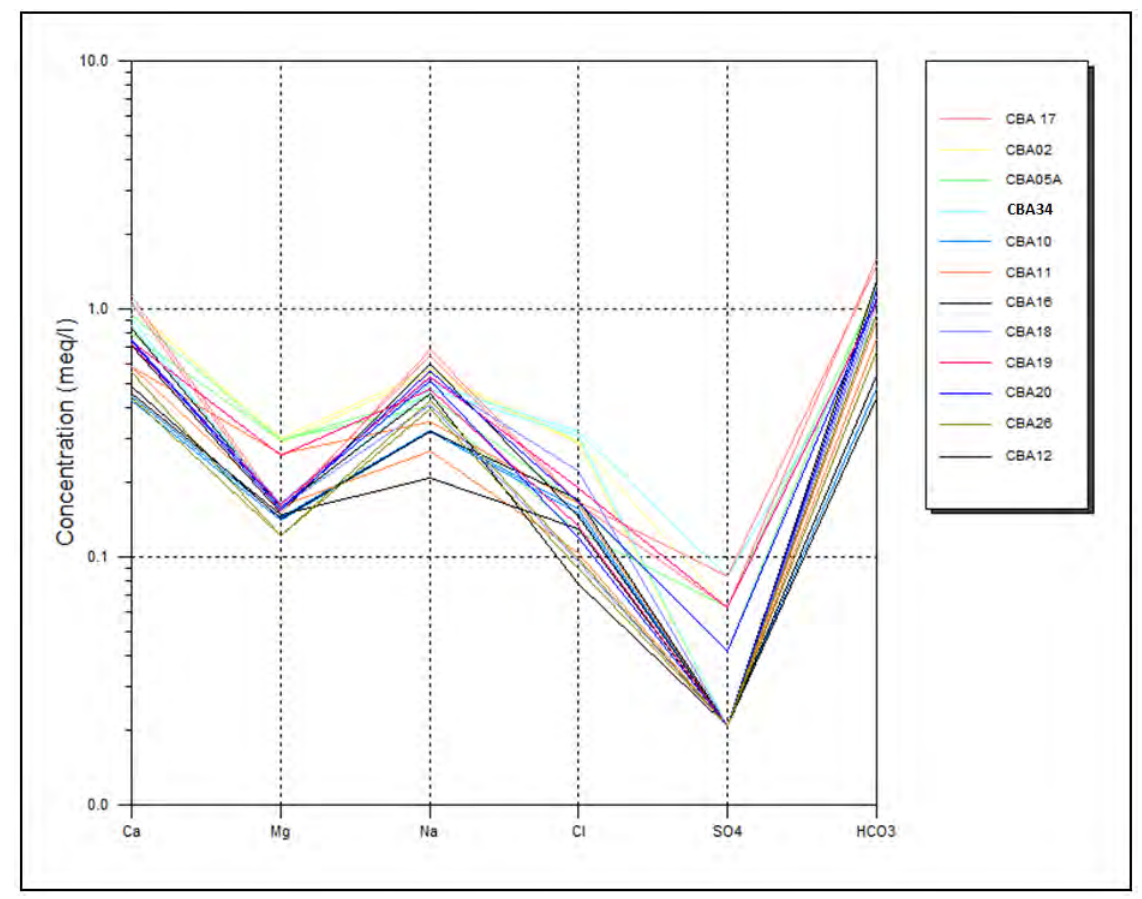

Figura 6. Diagrama de Schoeller das amostras de água subterrânea do SASG na área de estudo.

A diferença na concentração dos íons também dependem do volume da água do aquífero, tipo de ambiente geológico e formas de ocupação, características hidrogeológicas das camadas ou corpos aquíferos, características inerentes a água ( $\mathrm{pH}$, solubilidade, agressividade, entre outros), reações químicas e biológicas que acontecem dentro do próprio sistema de fluxo subterrâneo e características climáticas como pluviometria, evaporação, evapotranspiração e variação da temperatura (Feitosa, 2008).

$\mathrm{O}$ uso de relações entre diversos íons podem fornecer o tipo de reações químicas que estão associados aos processos hidroquímicos. A Tabela 3 apresenta a média dos valores encontradas das razões iônicas para as duas amostragem realizadas.

Tabela 3. Razões iônicas em meq $\mathrm{L}^{-1}$.

\begin{tabular}{c|ccccccccc}
\hline Poço & $\mathbf{r M g}^{+2} / \mathbf{C a}^{+2}$ & $\mathbf{r K}^{+} / \mathbf{N a}^{+}$ & $\mathbf{r N a}^{+} / \mathbf{C a}^{+2}$ & $\mathbf{r N a}^{+} / \mathbf{C a}^{+2}+\mathbf{M g}^{+2}$ & $\mathbf{r C l} / \mathbf{H C O}_{3}$ & $\mathbf{r N a} / \mathbf{C l}$ & $\mathbf{r H C O}{ }^{-} / \mathbf{C a}^{+2}$ & $\mathbf{r C a}^{+2} / \mathbf{M g}^{+2}$ & $\mathbf{r N a}^{+} / \mathbf{K}^{+}$ \\
\hline CBA02 & 0,284 & 0,207 & 0,545 & 0,424 & 0,239 & 1,924 & 1,185 & 3,527 & 4,828 \\
\hline CBA05A & 0,342 & 0,061 & 0,489 & 0,364 & 0,119 & 2,941 & 1,418 & 2,946 & 16,623 \\
\hline CBA10 & 0,329 & 0,423 & 0,742 & 0,558 & 0,301 & 2,107 & 1,178 & 3,038 & 2,365 \\
\hline CBA11 & 0,359 & 0,284 & 0,529 & 0,387 & 0,159 & 2,348 & 1,424 & 2,949 & 3,656 \\
\hline CBA12 & 0,307 & 0,334 & 0,558 & 0,428 & 0,315 & 1,741 & 1,041 & 3,265 & 3,261 \\
\hline CBA16 & 0,201 & 0,130 & 0,694 & 0,577 & 0,095 & 4,981 & 1,576 & 4,989 & 7,752 \\
\hline CBA17 & 0,140 & 0,042 & 0,611 & 0,536 & 0,107 & 4,041 & 1,416 & 7,138 & 23,901 \\
\hline CBA18 & 0,216 & 0,119 & 0,628 & 0,516 & 0,145 & 3,325 & 1,457 & 4,634 & 8,739 \\
\hline CBA19 & 0,286 & 0,201 & 0,688 & 0,539 & 0,144 & 3,172 & 1,552 & 3,670 & 4,988 \\
\hline CBA20 & 0,210 & 0,105 & 0,724 & 0,598 & 0,126 & 3,810 & 1,543 & 4,753 & 9,482 \\
\hline CBA26 & 0,247 & 0,124 & 0,834 & 0,668 & 0,119 & 4,342 & 1,629 & 4,092 & 9,485 \\
\hline CBA34 & 0,179 & 0,144 & 0,551 & 0,467 & 0,341 & 1,551 & 1,041 & 5,604 & 6,952 \\
\hline Média & $\mathbf{0 , 2 5 8}$ & $\mathbf{0 , 1 8 1}$ & $\mathbf{0 , 6 3 3}$ & $\mathbf{0 , 5 0 5}$ & $\mathbf{0 , 1 8 4}$ & $\mathbf{3 , 0 2 4}$ & $\mathbf{1 , 3 7 2}$ & $\mathbf{4 , 2 1 7}$ & $\mathbf{8 , 5 0 3}$ \\
\hline
\end{tabular}

As razões iônicas calculadas permitem evidenciar fluxo de água por rochas vulcânicas, observadas pela razão $\mathrm{rNa}^{+} / \mathrm{Cl}^{-}$maior que 0,7 como apresentado por Hem (1985) e pela 
relação $\mathrm{rNa}^{+} / \mathrm{Ca}^{+2}$ ser inferior a 1 , corroborando com a caracterização do diagrama Piper em águas bicarbonatadas cálcicas, valor também apontado por Portela Filho et al. (2005) no estudo da contribuição do aquífero basáltico sobrejacente ao Sistema Aquífero Guarani. A origem do bicarbonato é oriunda da dissolução da calcita, a qual apresenta uma razão teórica $\mathrm{rHCO}_{3} / \mathrm{Ca}^{+2}$ próxima de 1,5 (Roisenberg et al., 2003), sendo encontrado em média nos poços analisados um valor próximo a 1,4.

Outras razões iônicas como $\mathrm{rMg}^{+2} / \mathrm{Ca}^{+2}, \mathrm{rK}^{+} / \mathrm{Na}^{+} \mathrm{e} \mathrm{rNa}^{+} / \mathrm{Ca}^{+2}$ foram encontradas em média e respectivamente no valor de $0,258,0,181$ e 0,633 , valores que estão dentro dos intervalos atribuídos em outros estudos da Formação Serra Geral como de Gastmans et al. (2005). A razão $\mathrm{rNa}^{+} / \mathrm{K}^{+}$maior que 1 e mais elevada nos poços CBA05A e CBA17, é indicativa de um fluxo com maior tempo de permanência. Segundo Bittencourt et al. (2003), valores mais elevados da relação $\mathrm{rNa}^{+} / \mathrm{K}^{+}$são indicativos de fluxo em basaltos. Embora os poços tubulares selecionados, foram perfurados na sequência de rochas vulcânicas ácidas, as estruturas tectônicas encontradas nas litologias cortam diferentes derrames e podem proporcionar diferentes padrões de circulação, dando origem a padrões hidroquímicos e razões iônicas distintas.

\section{CONCLUSÕES}

$\mathrm{Na}$ região abrangida pelo município de Carlos Barbosa há ocorrência de aquíferos fraturados que fazem parte do Sistema Aquífero Serra Geral e que estão localizados nos derrames de rochas ácidas da Formação Serra Geral. A maioria das captações possuem profundidades entre 50 e 150 metros, nível estático localizado entre 0 e 5 metros, capacidade específica entre 0 e $0,3 \mathrm{~m}^{3} / \mathrm{h} / \mathrm{m}$ e vazão que varia entre 5 a $20 \mathrm{~m}^{3} \mathrm{~h}^{-1}$. O maior percentual de poços possui entre 1 a 3 entradas da água, localizadas em torno de 50 a 100 metros de profundidade e em zonas de média e alta densidade de fraturas, as quais possuem orientação preferencial de noroeste.

As águas subterrâneas que circulam por esses aquíferos são do tipo bicarbonatadas cálcicas ou magnesianas, predominando as águas bicarbonatadas mistas e cálcicas. A análise dos diagramas como Schoeller e Stiff indica a existência de um comportamento hidroquímico geral com pequenas variações nas concentrações dos íons analisados. Além disso, as razões iônicas encontradas são características da região de fluxo de água associado a rochas vulcânicas. Por fim a caracterização hidroquímica indica que as águas subterrâneas dessa região apresentam baixo grau de mineralização e baixo tempo de residência, sendo que as exceções foram encontradas em poços que possuíam entradas de água mais profundas.

\section{AGRADECIMENTOS}

Os autores agradecem ao Programa de Pós-Graduação em Recursos Hídricos e Saneamento Ambiental (IPH/UFRGS) e à Companhia Riograndense de Abastecimento (CORSAN) pela execução desta pesquisa e à FINEP, à Universidade de Brasília (UnB), ao Instituto de Saneamento Ambiental da Universidade de Caxias do Sul (ISAM/UCS) pelo financiamento do projeto.

\section{REFERÊNCIAS}

BETIOLLO, L. M. Caracterização estrutural, hidrogeológica e hidroquímica dos sistemas aquíferos Guarani e Serra Geral no nordeste do Rio Grande do Sul, Brasil. 2006. Dissertação (Mestrado em Geociências) - Instituto de Geociências. Programa de Pós-Graduação em Geociências, Universidade Federal do Rio Grande do Sul, Porto Alegre, 2006. 
BITTENCOURT, A. V. L.; ROSA FILHO E. F.; HINDI, E. C.; BUCHMANN FILHO, A. C. A influência dos basaltos e de misturas com águas de aquíferos sotopostos nas águas subterrâneas do Sistema Aquífero Serra Geral na bacia do rio Piquiri, Paraná - BR. Revista Águas Subterrâneas, v. 17, p. 67-76, 2003.

ESRI. ArcGis for Desktop 10.2. Redlands, 2013.

FEITOSA, F. A. C. Hidrogeologia: conceitos e aplicações. 3. ed., rev. e ampl. Rio de Janeiro: CPRM; LABHID, 2008. 812p.

FRAGA, C. G. Origem de fluoreto em águas subterrâneas dos sistemas aquíferos Botucatu e Serra Geral da Bacia do Paraná. 1992. 178p. Tese (Doutorado) - Instituto de Geociências, Universidade de São Paulo, São Paulo, 1992.

GASTMANS, D.; ALBERTO, M. C.; BUFFON, A. G. M.; MORAES, F. T.; SANTOS, M. M.; SILVA, J. R. M.; et al. Implicações hidroquímicas da interação rocha-água: interpretações através da representação gráfica de análises químicas de águas subterrâneas. In: ENCONTRO NACIONAL DE PERFURADORES DE POÇOS, 14.; SIMPÓSIO DE HIDROGEOLOGIA DO SUDESTE, 2., 2005, Ribeirão Preto. Anais... Ribeirão Preto: ABAS, 2005.

HAUSMAN, A. Comportamento do freático nas áreas basálticas do Rio Grande do Sul. Boletim Paranense de Geografia, v. 20, n. 18, p. 177-215, 1966.

HAUSMAN, A. Províncias hidrogeológicas do estado do Rio Grande do Sul, RS. Estudos

Tecnológicos: Acta Geológica Leopoldensia, Série Mapas, n. 2, p. 1-127, 1995.

HEM, L. D. Study and interpretation of the checimical characteristics of natural water. 3. edi. Washington: United States Government Printing Office, 1985. (U.S Geological Survey Water-Supply Paper, 2254).

LISBOA, N. A. Fácies, estratificações hidrogeoquímicas e seus controladores geológicos, em unidades hidrogeológicas do sistema aquífero Serra Geral, na bacia do Paraná, Rio Grande do Sul. 1996. 135p. Tese (Doutorado em Geociências) - Instituto de Geociências, Programa de Pós-Graduação em Geociências, Universidade Federal do Rio Grande do Sul, 1996.

MACHADO, J. L. F.; FREITAS, M. A. de. Projeto mapa hidrogeológico do Rio Grande do Sul: relatório final. Porto Alegre: CPRM, 2005. 65p. il. 1 mapa.

MOCELIN, R. C.; FERREIRA, F. J. F. Conectividade e compartimentação dos sistemas aquíferos Serra Geral e Guarani no sudoeste do estado do Paraná, Brasil. Revista Brasileira de Geociências, São Paulo, v. 39, n. 3, 2009.

MOBÜS, G. Analise estrutural e hidrogeológica do aquífero fraturado da Formação Serra Geral-Região noroeste do Rio Grande do Sul. 1987. 124p. Dissertação (Mestrado em Recursos Hídricos e Saneamento Ambiental) - Instituto de Pesquisas Hidráulicas, Universidade Federal do Rio Grande do Sul, Porto Alegre, 1987.

NANNI, A. S. O flúor em águas do Sistema Aquífero Serra Geral no Rio Grande do Sul: origem e condicionamento geológico. 2008. 127p. Tese (Doutorado em Geociências). Instituto de Geociências, Universidade Federal do Rio Grande do Sul, Porto Alegre, 2008 . 
PIPER A. M. A graphic procedure in the geochemical interpretation of water-analyses. Transactions of the American Geophysical Union, v. 25, p. 914-928, 1944.

PORTELA FILHO C. V.; FERREIRA F. J. F.; ROSA FILHO, E. F.; ROSTIROLLA S. P. Compartimentação magnética-estrutural do Sistema Aquífero Serra Geral e sua conectividade com o Sistema Aquífero Guarani na região central do arco de Ponta Grossa (Bacia do Paraná). Revista Brasileira de Geociências, São Paulo, v. 35, n. 3, p. 369-381, 2005.

REGINATO, P. A. R. Integração de dados geológicos para prospecção de aquíferos fraturados em trecho da Bacia Hidrográfica Taquari-Antas (RS). 2003. 254p. Tese (Doutorado em Engenharia) - Escola de Engenharia, Programa de Pós-Graduação em Engenharia de Minas, Metalúrgica e dos Materiais, Universidade Federal do Rio Grande do Sul, Porto Alegre, 2003.

REGINATO, P. A. R.; AHLERT, S.; GILIOLI, K. C.; CEMIN, G. Caracterização hidrogeológica e hidroquímica do aquífero livre do manto de alteração da Formação Serra Geral, na bacia hidrográfica Taquari-Antas, região nordeste do estado do Rio Grande do Sul. Revista Ambi-Agua, Taubaté, v. 7, n. 1, 2012. http://dx.doi.org/10.4136/ambi-agua.903

REGINATO, P. A. R. ; STRIEDER, A. J. Caracterização hidrogeológica e potencialidades dos aqüíferos fraturados da Formação Serra Geral na região nordeste do Estado do Rio Grande do Sul. In: CONGRESSO BRASILEIRO DE ÁGUAS SUBTERRÂNEAS, 13., 2004, Cuiabá. Anais... São Paulo: ABAS, 2004. v.1.

REGINATO, P. A. R.; AHLERT S.; SCHNEIDER, V. E. Caracterização hidroquímica do sistema aquífero Serra Geral na região nordeste do Rio Grande do Sul. Águas Subterrâneas, v. 27, n. 1, p. 65-78, 2013.

ROISENBERG, A.; VIERO, A. P. O vulcanismo mesozoico da Bacia do Paraná no Rio Grande do Sul. In: HOLZ, M.; DE ROS, L. F. Geologia do Rio Grande do Sul. Porto Alegre: CIGO/UFRGS. 2000.

ROISENBERG, C.; VIERO, A. P.; ROISENBERG, A.; SCHWARZBACH, M. S. R., MORANTE, I. C. Caracterização geoquímica e gênese dos principais íons das águas Subterrâneas de Porto Alegre, RS. Revista Brasileira de Recursos Hídricos, v. 8, n. 4, p. 137-147, out./dez. 2003.

SCHLUMBERGER WATER SERVICES. Software Visual Poços Pro. Reno, 1998.

SCHLUMBERGER WATER SERVICES. Software AcquaChem 5.1. Reno, 2008.

SCHOELLER, H. Utilité de la notion des exchanges de bases pour la comparasion des eaux souterraines. Société Géologie Comptes Rendus Sommaire et Bulletin, série 5, n. 5, p. 651-657, 1935.

STIFF, H. A. The interpretation of chemical water analysis by means of paterns. Journal of Petroleoum Technology, v. 3, n. 10, p. 15-17, 1951. http://dx.doi.org/10.2118/951376-G 


Ambiente \& Água - An Interdisciplinary Journal of Applied Science
ISSN 1980-993X - doi:10.4136/1980-993X
www.ambi-agua.net
E-mail: ambi-agua@agro.unitau.br

\title{
Análise fenotípica e genotípica de bactérias heterotróficas e fixadoras de nitrogênio em sedimento na bacia do Rio Cuiabá-MT
}

\author{
doi: 10.4136/ambi-agua.1207
}

Received: 30 Sep. 2013; Accepted: 27 Feb. 2014

\author{
Fernanda Viana da Cunha*; Selma Baia Batista \\ Universidade Federal de Mato Grosso (UFMT) - Cuiabá, MT, Brasil \\ Programa de Pós-Graduação em Recursos Hídricos \\ *Autor correspondente: e-mail: fernanda.vianacunha@gmail.com, \\ selfa@bol.com.br
}

\section{RESUMO}

Os sedimentos apresentam-se como um sistema complexo, que são afetados por parâmetros geológicos, hidrodinâmicos, químicos e biológicos, caracterizado por uma interação entre o ambiente sedimentar de cada região. O presente estudo consistiu em caracterizar a diversidade de bactérias heterotróficas totais e fixadores de nitrogênio em sedimentos do rio Cuiabá utilizando técnicas convencionais de microbiologia e de biologia molecular. As amostras de sedimento foram coletadas com periodicidade bimestral, em quatro pontos sendo estes: Cuiabazinho, Passagem da Conceição, Ribeirão dos Cocais e Barão de Melgaço. As amostras foram processadas através de diluições seriadas $\left(10^{-2}\right.$ a $\left.10^{-7}\right)$ em solução salina $0,85 \%$. Em seguida cultivadas em placa de Petri através da técnica de Spreed Plate, em meio de cultivo Trypic Soy Agar (TSA) para bactérias heterotróficas totais e para bactérias nitrificantes foram utilizados meios seletivos (NFB, JMV e Meio 79) incubadas a $35^{\circ} \mathrm{C}$. Posteriormente as estirpes bacterianas foram reisoladas em Agar Nutriente (AN) a fim de obter cultura pura para análise morfotintorial de Gram. Este teste permitiu verificar que dos 202 isolados bacterianos, 59\% eram bastonetes positivos, sendo que, a maior quantificação bacteriana obtida foi no meio de cultivo TSA, comparado aos outros meios de cultura. $\mathrm{O}$ perfil da comunidade bacteriana apresentou na sua maioria bactérias da família Bacillaceae com $28 \%$, sendo que as mesmas foram utilizadas para a análise molecular por Box-PCR, que apresentou uma riqueza de espécies. Esses resultados indicam a importância de pesquisas sobre diversidade microbiana de sedimentos no Estado de Mato Grosso que utilizam técnicas moleculares.

Palavras-chave: autodepuração, biologia molecular, Box-PCR.

\section{Phenotypic and genotypic analysis of heterotrophic bacteria and nitrogen-fixing in sediment in the basin of the Cuiaba River - MT}

\begin{abstract}
Sediments are complex systems that are affected by geological, hydrodynamic, chemical and biological parameters, as determined by interactions between the sedimentary environments of each region. This study aimed to characterize the diversity of total heterotrophic bacteria and nitrogen fixers in Cuiabá River sediments using conventional
\end{abstract}


techniques of microbiology and molecular biology. Sediment samples were collected bimonthly from four points: Cuiabazinho, Passagem da Conceição, Ribeirão Cocais and Barão de Melgaço. The samples were processed in serial dilutions $\left(10^{-2}\right.$ to $\left.10^{-7}\right)$ in $0.85 \%$ saline solution. They were then cultured in Petri dishes using the Spread Plate technique in the Trypic Soy Agar (TSA) culture medium for total heterotrophic bacteria and selective medium (NFB, JMV and culture median 79) incubated at $35^{\circ} \mathrm{C}$ for nitrifying bacteria. The bacterial strains were then re-isolated on Nutrient Agar (NA) in order to obtain a pure culture for the Gram analysis morphotypes. This test revealed that, of the 202 bacterial isolates, $59 \%$ were positive rods. The largest bacterial count was obtained in the TSA medium, as compared to other means of culture. The profile of the bacterial community showed that most, or $28 \%$, of the bacteria were of the Bacillaceae family and these were used for molecular analysis using Box-PCR, which showed a great diversity of species. These results indicate the importance of microbial diversity research in sediments in Mato Grosso State using molecular techniques.

Keywords: Box-PCR, micro-organisms, self-depuration.

\section{INTRODUÇÃO}

A bacia hidrográfica do rio Cuiabá é tributária do rio Paraguai na parte superior do seu curso, e por isso é considerada uma sub-bacia do rio Paraguai, e está localizada na região Centro-Oeste, englobando parte de Mato Grosso e uma pequena porção do norte de Mato Grosso do Sul. Este também banha a planície Pantaneira, extravasando suas águas para fora do leito no período de cheia, inundando campos e lagoas, contribuindo para formar uma das maiores áreas alagáveis contínuas e também uma das áreas referências em biodiversidade no mundo (Cuiabá, 2005).

É comum verificar no Estado de Mato Grosso a ocupação de cabeceiras de drenagem, principalmente pela agricultura, e a destruição da mata ciliar, situações essas que tornam os recursos hídricos extremamente vulneráveis à contaminação, onde no trecho médio da bacia, altamente urbanizado e industrializado, a principal preocupação é o esgoto doméstico, o qual é responsável por cerca de $80 \%$ da carga orgânica no rio, sendo os restantes $20 \%$ resultantes da atividade agro-industrial (Shinma, 2004; Calheiros, 2008).

Porém, a situação ambiental e hídrica da bacia do rio Cuiabá não resulta apenas da ocupação humana, mas também das próprias características topográficas da região (ANA, 2003), e que pode ser afetada pela sedimentação e alterações dos padrões de ocupação do solo no trecho superior da bacia, uma vez que, os solos arenosos e a topografia acidentada desta região produzem elevadas taxas de sedimentação no rio (Shinma, 2004).

Os ambientes aquáticos são fundamentais para o estabelecimento de muitos grupos de organismos no planeta, sendo assim, a disponibilidade e a boa qualidade destes ambientes é essencial para a manutenção da biodiversidade aquática (Odum, 2007). Segundo Begon et al. (2006), um dos aspectos ecológicos mais impressionantes dos micro-organismos é a sua ubiqüidade, sendo filogeneticamente relacionados, em diferentes proporções, ocorrendo em sincronia no tempo e no espaço, e realizando diversas funções, as bactérias podem representar mais de $90 \%$ desses micro-organismos.

As bactérias heterotróficas desempenham papel importante no estudo dos impactos ambientais, bem como nos sedimentos, sendo considerado um componente importante da comunidade biótica no ecossistema (Gimenes et al., 2010). Estes podem estar associados à produção e o consumo da matéria orgânica e ainda controlar a ciclagem do nitrogênio desempenhando um papel importante nesse processo (Carvalho e Paranhos, 2010). Dessa maneira, o conhecimento da diversidade microbiana é essencial para entender a relação entre os parâmetros ambientais e o funcionamento dos ecossistemas, e isso pode ser possível com o 
avanço da biologia molecular e o uso de novas técnicas no estudo da ecologia desses microorganismos, que permite conhecer sua diversidade e distribuição (Carvalho e Paranhos, 2010).

Como alternativa existem diversos métodos moleculares disponíveis baseados na manipulação dos ácidos nucléicos seja o ácido desoxirribonucléico (DNA) ou o ácido ribonucléico (RNA) que podem ser extraídos de estirpes crescidas em meios de cultura ou até mesmo a partir de amostras diretamente do ambiente, em que se pode citar a PCR, e suas variações, RFLP- PCR, RT-PCR, Nested-PCR, Rep-PCR (REP, ERIC, BOX), PCR em tempo real, e DGGE, Sequenciamento, entre outros (Reis Jr. et al., 2002; Eça, 2004).

O presente estudo consiste em caracterizar a diversidade de bactérias heterotróficas e fixadores de nitrogênio em sedimentos do rio Cuiabá utilizando uma abordagem polifásica de microbiologia convencional e molecular.

\section{MATERIAL E MÉTODOS}

\section{1. Área de estudo}

O estudo foi realizado na bacia do Rio Cuiabá, que se encontra localizada entre as coordenadas geográficas $14^{\circ} 18^{\prime}$ e $17^{\circ} 00^{\prime}$ de latitude Sul e $54^{\circ} 40^{\prime}$ e $56^{\circ} 55^{\prime}$ de longitude Oeste, o Rio Cuiabá, que drena uma área aproximada de $21.730 \mathrm{~km}^{2}$ até a cidade de Cuiabá, sendo este um dos principais afluentes do Rio Paraguai (Cuiabá, 2005).

\subsection{Delineamento amostral}

Foram realizadas seis coletas, sendo a primeira em Julho de 2011 e a última em Maio de 2012, com periodicidade bimestral, contemplando um ciclo anual durante os períodos de seca (maio, julho e setembro) e chuva (novembro, janeiro e março) em quatro pontos amostrais, iniciando-se na nascente da cabeceira da bacia do Rio Cuiabá até a jusante da cidade de Barão de Melgaço. Os pontos escolhidos podem ser observados na Figura 1.

P1 - Cuiabazinho (próximo à área de nascente);

P4 - Passagem da Conceição;

P6 - Jusante do Córrego Ribeirão dos Cocais (avaliando a influência do Rio Coxipó);

P8 - Jusante de Barão de Melgaço.

Amostras de sedimento, foram constituída por sub-amostras com distribuição aleatória, realizadas com um amostrador do tipo raspador de fundo, sendo impossível representar profundidade devido ao amostrador ser do tipo raspador. Assim, em cada ponto amostral foram realizadas três coletas $\mathrm{A}, \mathrm{B}$ e C o qual cada uma delas foi composta de três amostras simples (Costa, 2001).

\subsection{Análise física e química}

As análises de textura do sedimento empregado para designar a proporção relativa das frações argila, silte ou areia, que se diferenciam entre si pelo tamanho de suas partículas (granulometria). Para a dispersão das amostras de sedimento foram adicionados 25 gramas de solo peneirados em frascos, nestes foram colocados $50 \mathrm{ml}$ de água destilada; $10 \mathrm{ml}$ de $\mathrm{NaOH}$ a $6 \%$; em agitação em mesa agitadora por 16 horas. Em seguida completou o volume da proveta até $1000 \mathrm{ml}$ com água destilada este conteúdo com agitador manual por 30 vezes, a leitura da fração de areia e argila foi realizada pela técnica do densímetro de Bouyoucos, e a fração silte foi calculada por diferença (EMBRAPA, 1979).

As análises foram realizadas no laboratório de Física do Solo no Departamento de Engenharia Florestal da Universidade Federal de Mato Grosso, FAMEV. 


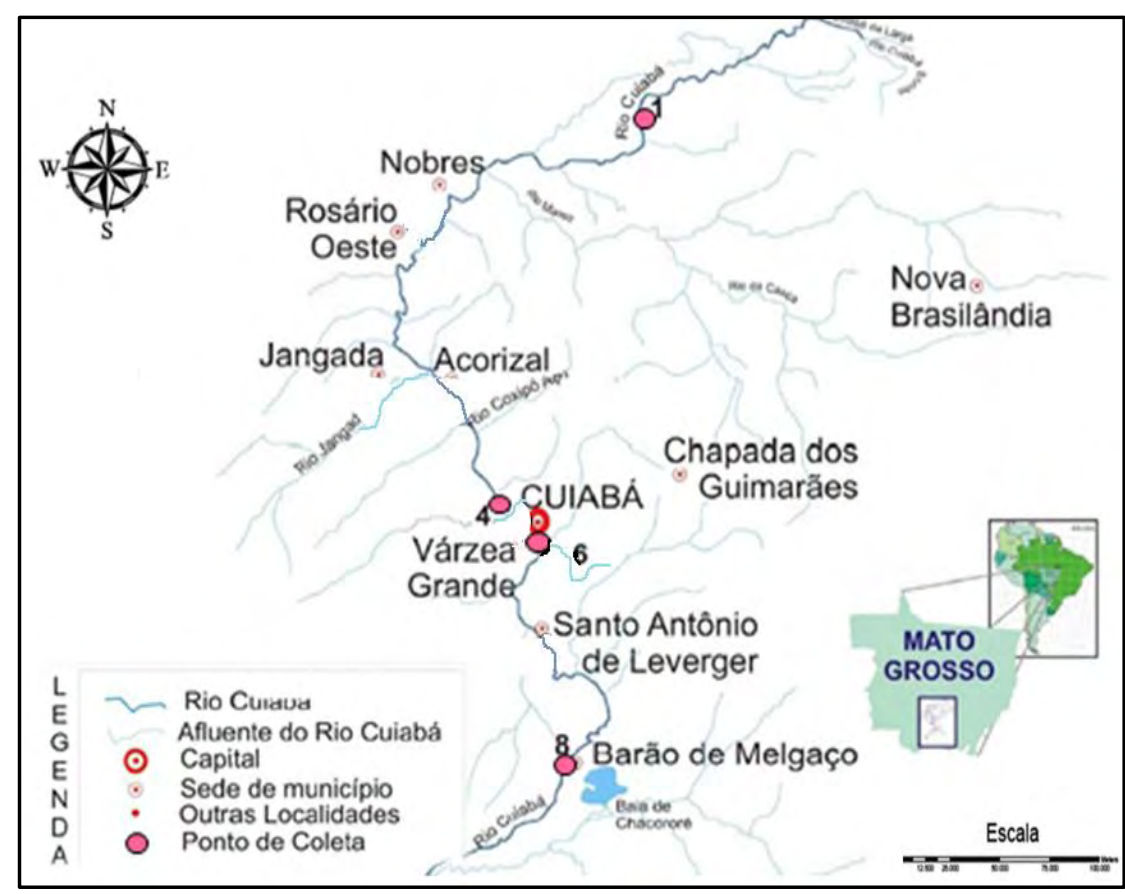

Figura 1. Localização das estações de amostragem de sedimento no rio Cuiabá.

\subsubsection{ANÁLISE QUÍMICA}

A concentração dos elementos químicos fósforo $(\mathrm{P})$, potássio $(\mathrm{K})$, matéria orgânica e potencial hidrogeniônico $(\mathrm{pH})$ das amostras foi determinada segundo as recomendações de EMBRAPA (1997).

As análises foram realizadas no laboratório de Fertilidade do Solo no Departamento de Engenharia Florestal da Universidade Federal de Mato Grosso, FAMEV.

\subsection{Processamento e quantificação bacteriana}

Para a quantificação bacteriana foram pesados $5 \mathrm{~g}$ de sedimento e adicionado em um Erlenmeyer contendo $45 \mathrm{~mL}$ de solução extratora adicionado de $1 \%$ de Tween 80 e $1 \%$ de pirofosfato de sódio, após etapa de agitação em mesa orbital a $220 \mathrm{rpm}$ por 30 minutos em temperatura ambiente. Após a homogeneização das amostras, foram retiradas uma alíquota de $1 \mathrm{~mL}$ desse material para iniciar as diluições seriadas necessárias para o processamento das amostras.As diluições $\left(10^{-2}\right.$ a $\left.10^{-6}\right)$ foram feitas em tubos de ensaio contendo $9 \mathrm{~mL}$ de solução salina $(0,85 \% \mathrm{NaCl})$ estéril (Neder, 1992). Para a quantificação de bactérias heterotróficas totais, foram inoculado $100 \mu \mathrm{L}$ das diluições $10^{-4}$ a $10^{-6}$, em triplicata, adicionado em meio TrypicSoy Agar (TSA), acrescentado de $0,04 \mathrm{~g} \mathrm{~L}^{-1}$ de ciclohexamida (fungicida), e para as bactérias fixadoras de nitrogênio foi realizado o mesmo processo citado acima, porém, inoculado em meios específicos e seletivos, que foram o meio NFB, JMV e Meio 79 segundo Döbereiner et al. (1999), e utilizando a técnica de Spread plate, as mesmas foram incubadas em estufa de crescimento por $35^{\circ} \mathrm{C}$ por $144 \mathrm{~h}$. Após a verificação do crescimento, foram realizadas contagens de unidades formadoras de colônia (UFC's) pelo método de Contagem Padrão em Placas (CPP) (Tortora et al., 2012).O número de colônias foi multiplicado pelo inverso do fator de diluição para obtenção do valor de $\mathrm{UFC} \cdot \mathrm{mL}^{-1}$ de amostra e os valores expressos em Log de UFC g ${ }^{-1}$ de sedimento (Tortora et al., 2012).

\subsection{Caracterização Fenotípica}

Após a análise morfotintorial de Gram, foram realizados teste fisiológico e bioquímicas para todas as cepas selecionadas, a fim de caracterizar as estirpes fenotipicamente, uma prova a mais na identificação das bactérias isoladas. Os testes realizados foram; redução do nitrato, 
teste da catalase, teste de oxidação/fermentação de glicose e teste de Oxidase, e teste de motilidade segundo MacFaddin (1980).

\subsection{Análise estatística}

Os tratamentos estatísticos envolveram a análise descritiva para identificação de valores discrepantes, utilizando o teste não paramétrico de Kruskal-Wallis, pelo Software Statistica 7.0.

\subsection{Caracterização genotípica - BOX-PCR}

Para a extração do material genômico foi utilizado kit Genomic DNA fromTissueNucleoSpin ${ }^{\circledR}$ seguindo as instruções do fabricante.

Os fragmentos foram visualizados pela eletroforese em gel de agarose (Invitrogen) $0,5 \%$ a 100 Volts por 30 minutos; o gel foi corado com brometo de etídio e foi usado um padrão de peso molecular $100 \mathrm{pb}$ e foi visualizada em um transluminador de luz UltraVioleta $(254 \mathrm{~nm})$. A avaliação da diversidade genética dos isolados bacterianos foi realizada usando a técnica Box-PCR, utilizando o primer Box-1AR ('5CTACGGCAAGGCGACGCTGACG-3') (Versalovic et al., 1994). A reação de amplificação foi realizada com os seguintes volumes: $12,5 \mu 1$ de $\mathrm{GoTaq}^{\circledR}$. A amplificação foi realizada usando os seguintes ciclos: um ciclo de desnaturação inicial a $95^{\circ} \mathrm{C}$ por $7 \mathrm{~min} ; 35$ ciclos de desnaturação $\left(1\right.$ min a $\left.94^{\circ} \mathrm{C}\right)$, anelamento $\left(1 \mathrm{~min}\right.$ a $\left.53^{\circ} \mathrm{C}\right)$ e extensão $\left(8 \mathrm{~min}\right.$ a $\left.65^{\circ} \mathrm{C}\right)$; um ciclo de extensão final a $65^{\circ} \mathrm{C}$ por $16 \mathrm{~min}$; manutenção a $4^{\circ} \mathrm{C}$. Os fragmentos amplificados foram separados por eletroforese a $100 \mathrm{~V}$ em gel de agarose a $2 \%$ em tampão TAE $0,5 \mathrm{X}$. Após seis horas de corrida, o gel foi corado em brometo de etídeo e os fragmentos amplificados foram visualizados em transluminador UV $(254 \mathrm{~nm})$, assim como o produto da extração, para os amplificados também foi usado opadrão de peso molecular $100 \mathrm{pb}$.

O perfil de bandas geradas pela amplificação foram transformadas em dados binários (presença e ausência de bandas), e em seguida utilizadas para obter um dendrograma de similaridade calculado pelo coeficiente de Jaccard e agrupado utilizando o algoritmo UPGMA (UnweightedPair-GroupMethodwithArithmeticalAverage), utilizando o software Bionumerics 7.0 (AppliedMathematics, Kortrijk, Bélgica).

\section{RESULTADOS E DISCUSSÃO}

\subsection{Análise física e química}

A análise física por granulometria, para o teor de argila, silte e areia, nos pontos P1, P4, P6 e P8, da bacia do Rio Cuiabá, teve grande concentração de areia em todos os períodos de coleta, principalmente no Ponto P4 (Passagem da Conceição), localizado em um perímetro urbano, ponto muito conhecido por ser utilizado por banhista (ANA, 2011).

Todas as amostras apresentaram $\mathrm{pH}$ em torno cinco (5.0), essa acidez do sedimento pode ser devido as características do solo, que em sua maioria é lixiviado para a bacia. Como os solos da região são conhecidos por serem ácidos e de baixa fertilidade, necessitam de técnicas de calagem e adubação (Pereira et al., 1999).

Os resultados das análises químicas do sedimento para fósforo $(\mathrm{P})$, potássio $(\mathrm{K})$ e matéria orgânica (MO), e pH, foram caracterizados como sendo de maior relevância para o estudo proposto (Tabela 1). 
Tabela 1. Análises químicas referentes a $\mathrm{pH}, \mathrm{K}, \mathrm{P}$ e MO.

\begin{tabular}{|c|c|c|c|c|c|}
\hline \multirow[b]{2}{*}{ Coleta } & \multirow[b]{2}{*}{ Pontos amostrais } & \multicolumn{4}{|c|}{ Variáveis } \\
\hline & & $\underset{\left(\mathrm{CaCl}_{2}\right)}{\mathbf{p H}}$ & $\underset{\left(\mathbf{m g} / \mathbf{d m}^{3}\right)}{\mathbf{K}}$ & $\begin{array}{c}\mathbf{P} \\
\left(\mathbf{m g} / \mathbf{d m}^{3}\right)\end{array}$ & $\begin{array}{l}\text { MO } \\
(\%)\end{array}$ \\
\hline \multirow{4}{*}{$1^{\mathrm{a}}$} & $\mathrm{P} 1$ & 5,42 & 7,02 & 32,09 & 7,41 \\
\hline & P4 & 5,48 & 2,92 & 26,82 & 1,53 \\
\hline & P6 & 5,51 & 4,81 & 46,62 & 2,62 \\
\hline & P8 & 6,10 & 6,05 & 33,46 & 1,98 \\
\hline \multirow{4}{*}{$2^{\mathrm{a}}$} & $\mathrm{P} 1$ & 5,52 & 173,89 & 26,06 & 62,85 \\
\hline & P4 & 6,28 & 138,07 & 23,62 & 134,24 \\
\hline & P6 & 5,87 & 131,56 & 46,80 & 205,61 \\
\hline & P8 & 6,01 & 149,14 & 28,90 & 121,38 \\
\hline \multirow{4}{*}{$3^{\mathrm{a}}$} & $\mathrm{P} 1$ & 6.6 & 4,22 & 24,86 & 2,78 \\
\hline & P4 & 5,78 & 7,14 & 30,28 & 3,41 \\
\hline & P6 & 4,73 & 5,36 & 59,85 & 4,35 \\
\hline & P8 & 5,31 & 7,40 & 35,16 & 3,95 \\
\hline \multirow{4}{*}{$4^{\mathrm{a}}$} & P1 & 5,84 & 9,21 & 37,81 & 5,19 \\
\hline & P4 & 5,54 & 7,00 & 29,89 & 4,64 \\
\hline & P6 & 5,90 & 9,98 & 34,62 & 8,45 \\
\hline & P8 & 5,80 & 13,40 & 39,54 & 6,10 \\
\hline \multirow{4}{*}{$5^{\mathrm{a}}$} & $\mathrm{P} 1$ & 5,81 & 8,01 & 31,95 & 4,76 \\
\hline & P4 & 5,64 & 7,10 & 23,14 & 4,95 \\
\hline & P6 & 5,43 & 8,44 & 35,10 & 7,78 \\
\hline & P8 & 5,33 & 14,67 & 22,77 & 6,47 \\
\hline \multirow{4}{*}{$6^{\mathrm{a}}$} & $\mathrm{P} 1$ & 5,04 & 7,29 & 32,50 & 4,84 \\
\hline & $\mathrm{P} 4$ & 5,79 & 8,29 & 27,41 & 4,54 \\
\hline & P6 & 5,07 & 4,57 & 67,09 & 3,02 \\
\hline & P8 & 6,10 & 11,38 & 35,40 & 10,67 \\
\hline
\end{tabular}

Em relação as análise de fósforo, potássio e matéria orgânica, verificou-se pouca variação em relação os pontos de coleta. Contudo uma variação entre os meses de coleta foi observada, principalmente referentes as análises de potássio e matéria orgânica.

E esse valor referenciado do fósforo, bem como do potássio, pode ser reflexo das práticas agrícolas na bacia, e segundo Rheinheimer et al. (2003) são vistos como uma importante fração presentes nos solos erodidos e está fortemente associada aos minerais de argila, e as práticas de fertilização dos solos.

Os valores de matéria orgânica podem ser evidenciados devido a uma maior atividade bacteriana. Visto que no trabalho realizado por Xavier et al. (2006), a utilização preferencial de diferentes componentes da matéria orgânica por certo grupos de bactérias, pelo seu metabolismo da comunidade, é sempre acompanhado pelas mudanças na sua composição. E sabe-se que as alterações que ocorrem no sistema aquático são reflexos em parte dos impactos sofridos pelo ecossistema terrestre, sendo os sedimentos um importante elo entre esses dois sistemas (Minella et al., 2007).

\subsection{Caracterização Microbiológica}

Avaliando o crescimento bacteriano de heterotróficos totais em meio TSA e bactérias fixadoras de nitrogênio crescidas nos meios 79, NFB e JMV incubados por 144 horas, verificou-se, que não houve grandes variações por pontos amostrais como verificado nas Figuras 2, 4, 6 e 8. Porém em relação ao tempo, foi possível verificar uma variação representativa entre os meses amostrados conforme Figuras 3, 5, 7 e 9. 


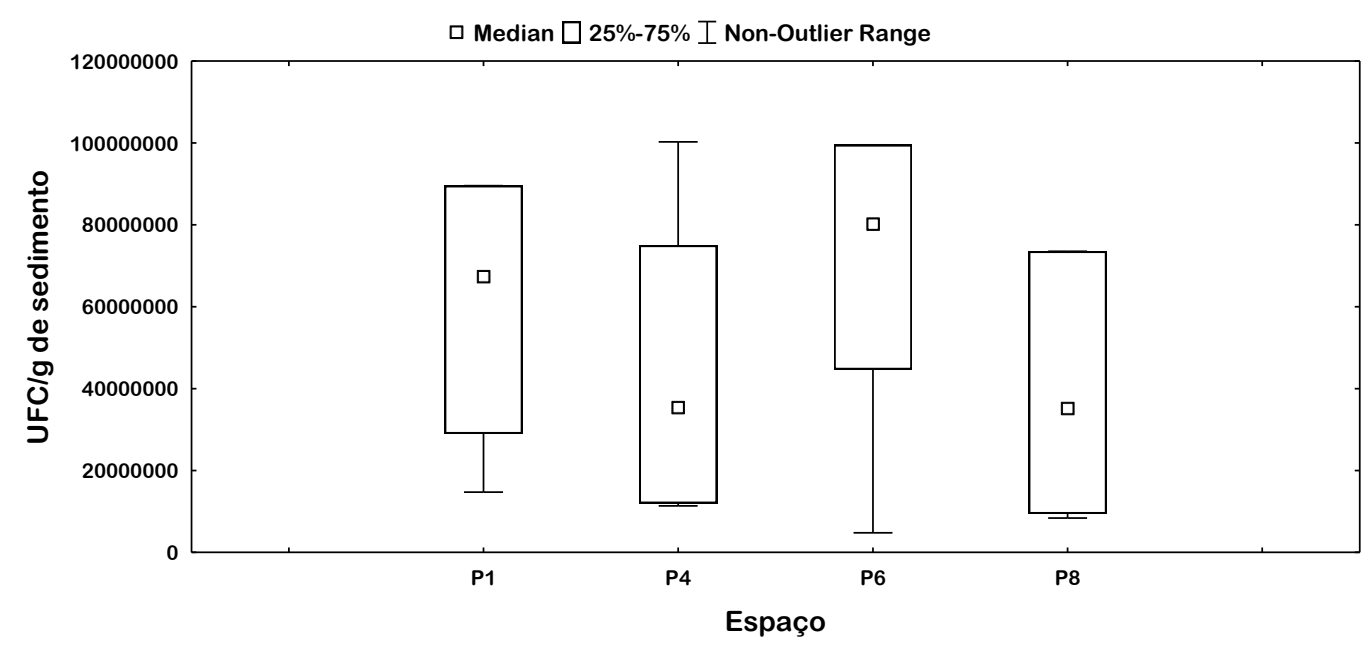

Figura 2. Representação gráfica do Box-plot para análise do meio TSA $(\mathrm{KW}-\mathrm{H}(3 ; 24)=1.78 ; \mathrm{p}=0.6193)$.

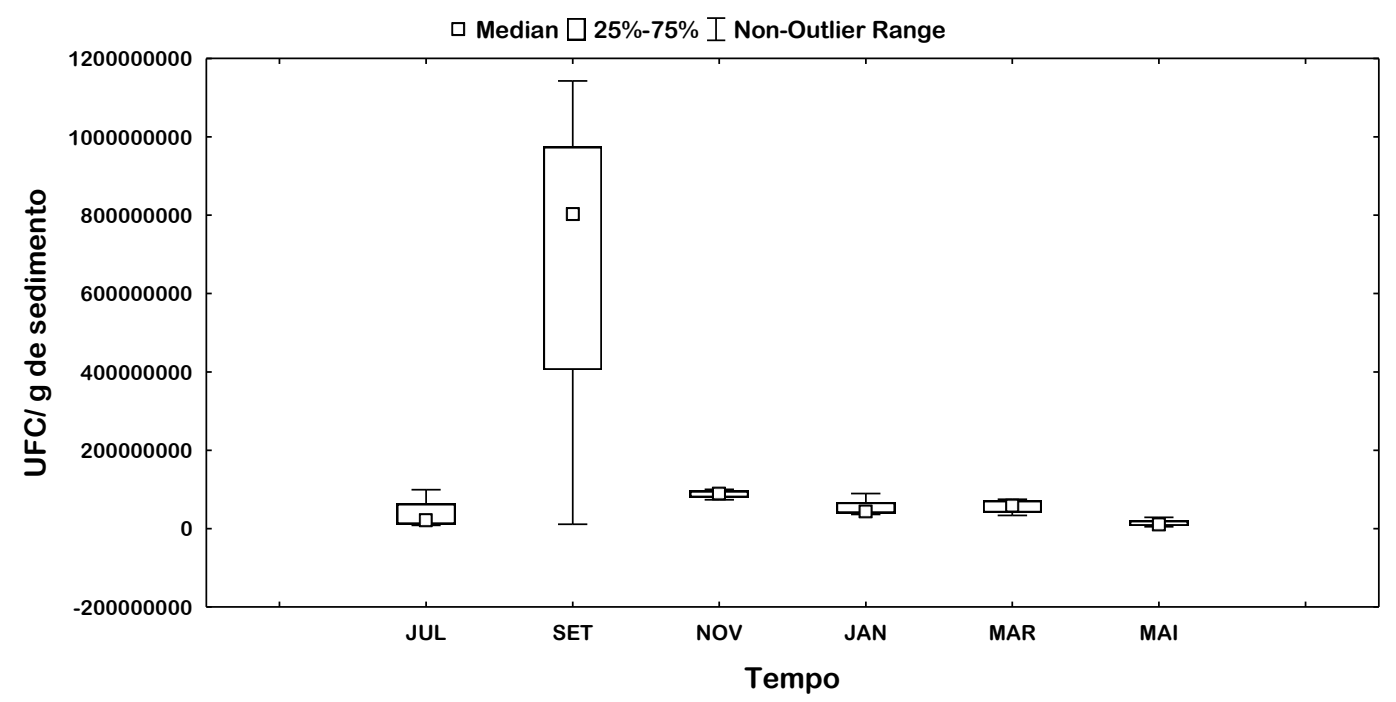

Figura 3. Representação gráfica do Box-plot para análise do meio TSA (KW-H(5;24) $=11,66 ; \mathrm{p}=0,0398)$.

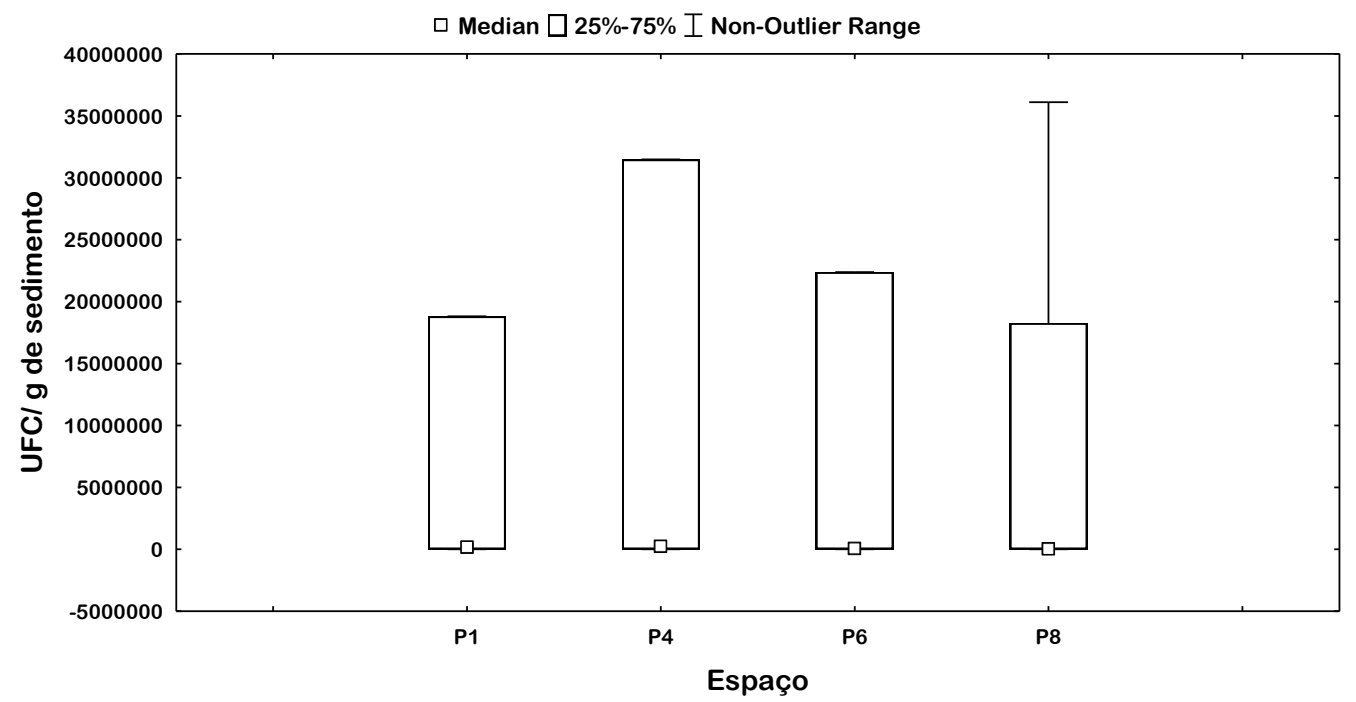

Figura 4. Representação gráfica do Box-plot para análise do meio JMV: $\mathrm{KW}-\mathrm{H}(3 ; 24)=0,2422 ; \mathrm{p}=0,9705$. 


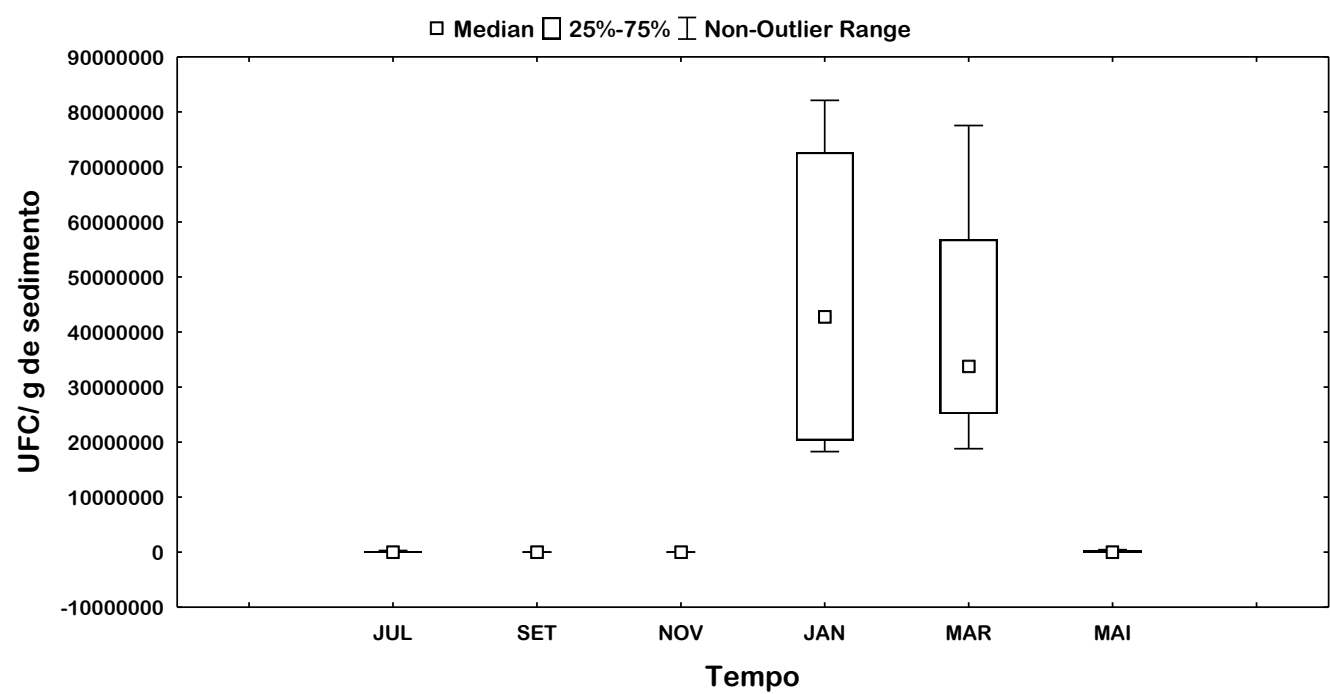

Figura 5. Representação gráfica do Box-plot para análise do meio JMV (KW$\mathrm{H}(5 ; 24)=21,2978 ; \mathrm{p}=0,0007$.

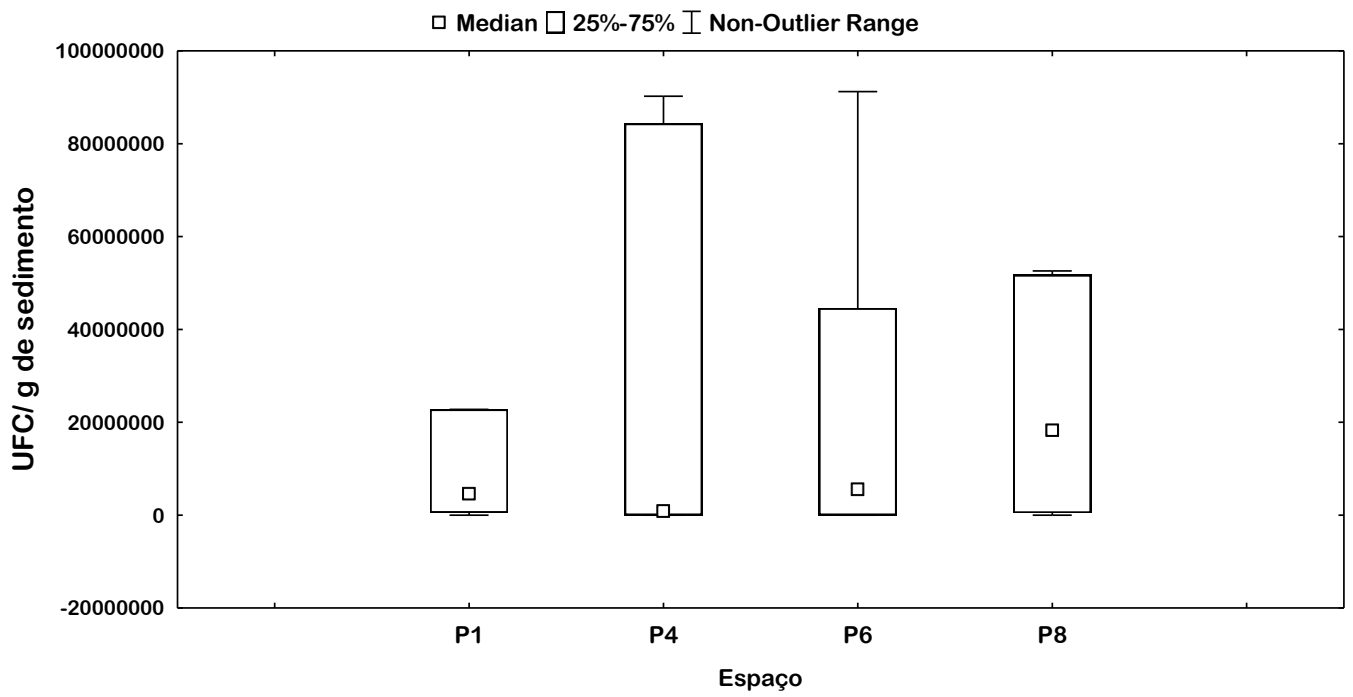

Figura 6. Representação gráfica do Box-plot para análise do meio 79 (KW-H(3;24) = 0,$1269 ; \mathrm{p}=0,9884$.

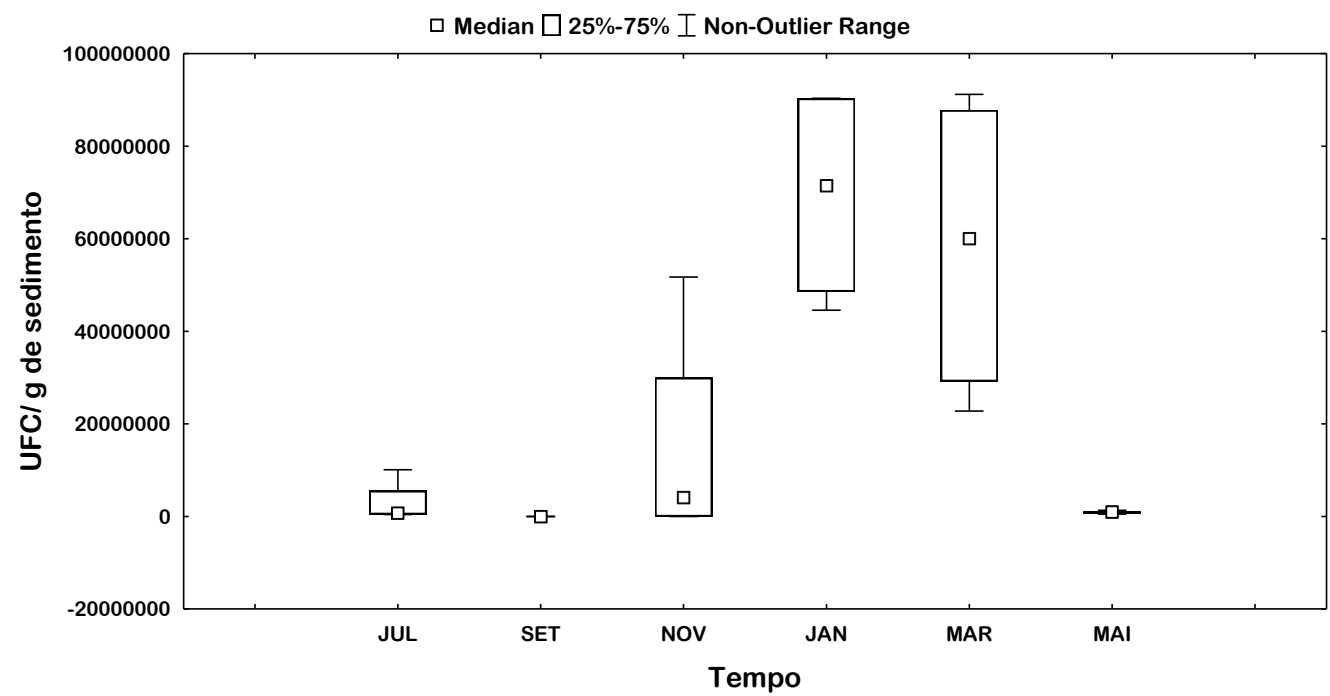

Figura 7. Representação gráfica do Box-plot para análise do meio 79 (KW-H(5;24) $=17,1916 ; \mathrm{p}=0,0042)$. 


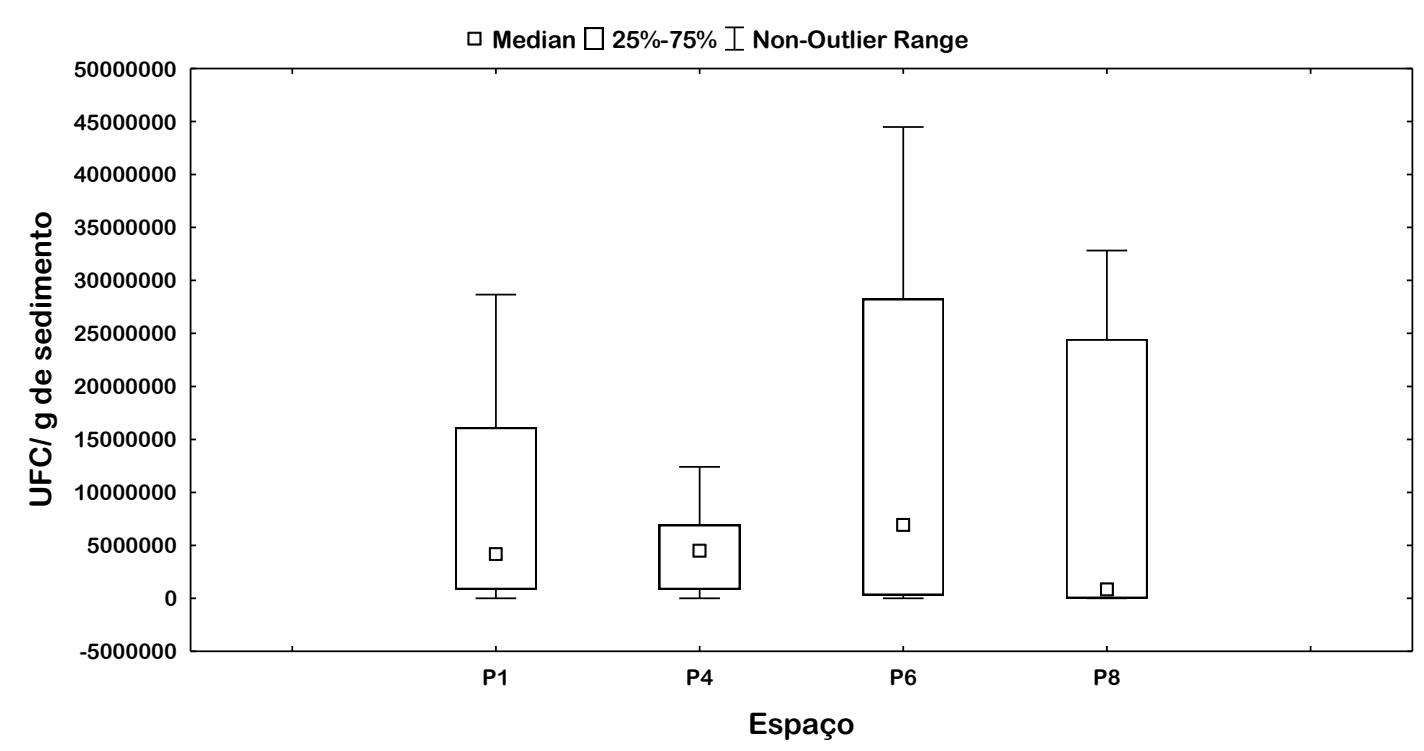

Figura 8. Representação gráfica do Box-plot para análise do meio NFB $(\mathrm{KW}-\mathrm{H}(3 ; 24)=$ 0,$6523 ; p=0,8844$.

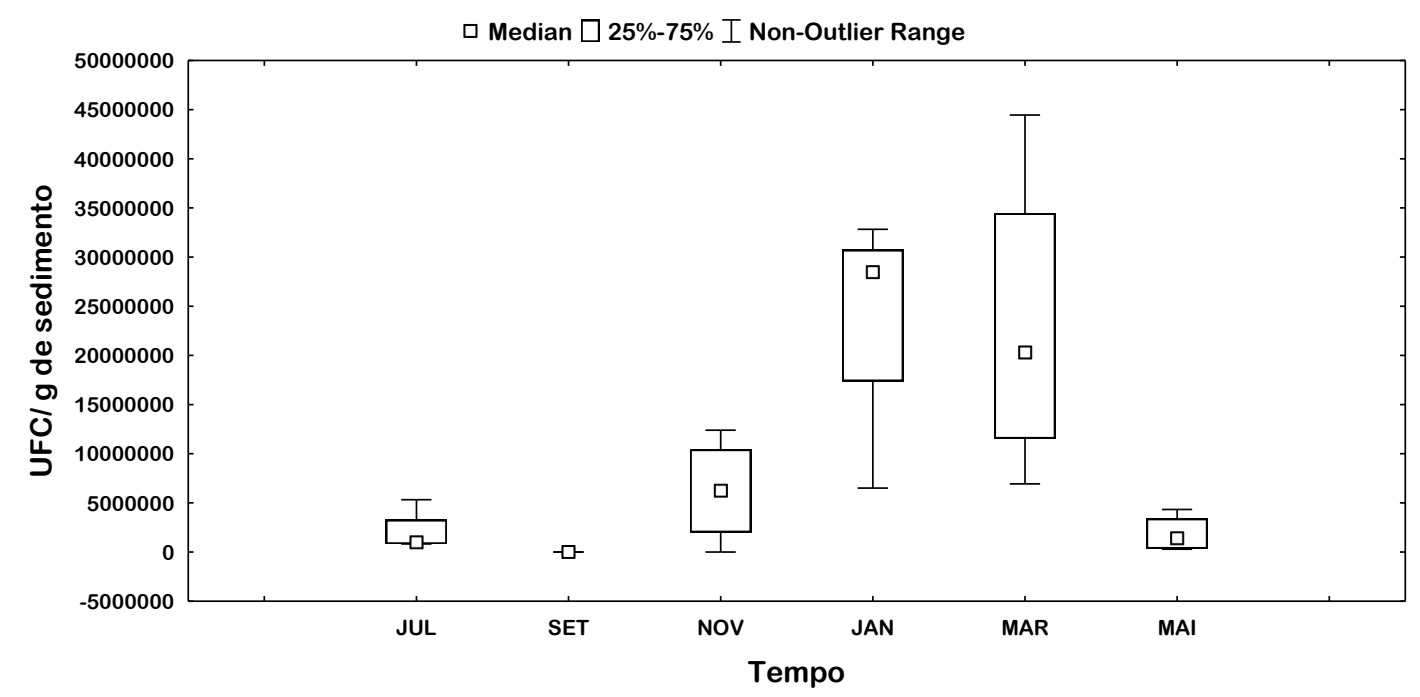

Figura 9. Representação gráfica do Box-plot para análise do meio NFB: KW-H(5;24) = 17,$6333 ; p=0,0034$.

De acordo com os resultados apresentados, pode-se inferir que o rio ainda possui capacidade de autodepuração, restabelecendo o equilíbrio, após as alterações induzidas pelos despejos efluentes. Segundo Von Sperling (2005) e Andrade (2010) a autodepuração é um processo natural, no qual cargas poluidoras, de origem orgânica lançadas em um corpo d'água são neutralizadas, pela decomposição da matéria orgânica por micro-organismos aeróbios.

Conforme já observado por Vrede (2005), variações na temperatura e nos nutrientes inorgânicos e orgânicos podem limitar a atividade e a abundância bacteriana. A quantidade e a qualidade da matéria orgânica do sedimento tem sido consideradas como os principais fatores determinantes na estruturação da comunidade microbiana (Haglund et al., 2003).

Segundo Tammert et al. (2008) e Reis et al. (2008), mudanças na concentração de importantes fatores ambientais podem provocar o desequilíbrio na comunidade microbiana, podendo inibir determinadas populações de micro-organismos e estimular outras populações insensíveis ao composto. 
Os resultados indicam que o rio possui capacidade de autodepuração e de restabelecimento do equilíbrio após as alterações induzidas pelos despejos de efluentes.

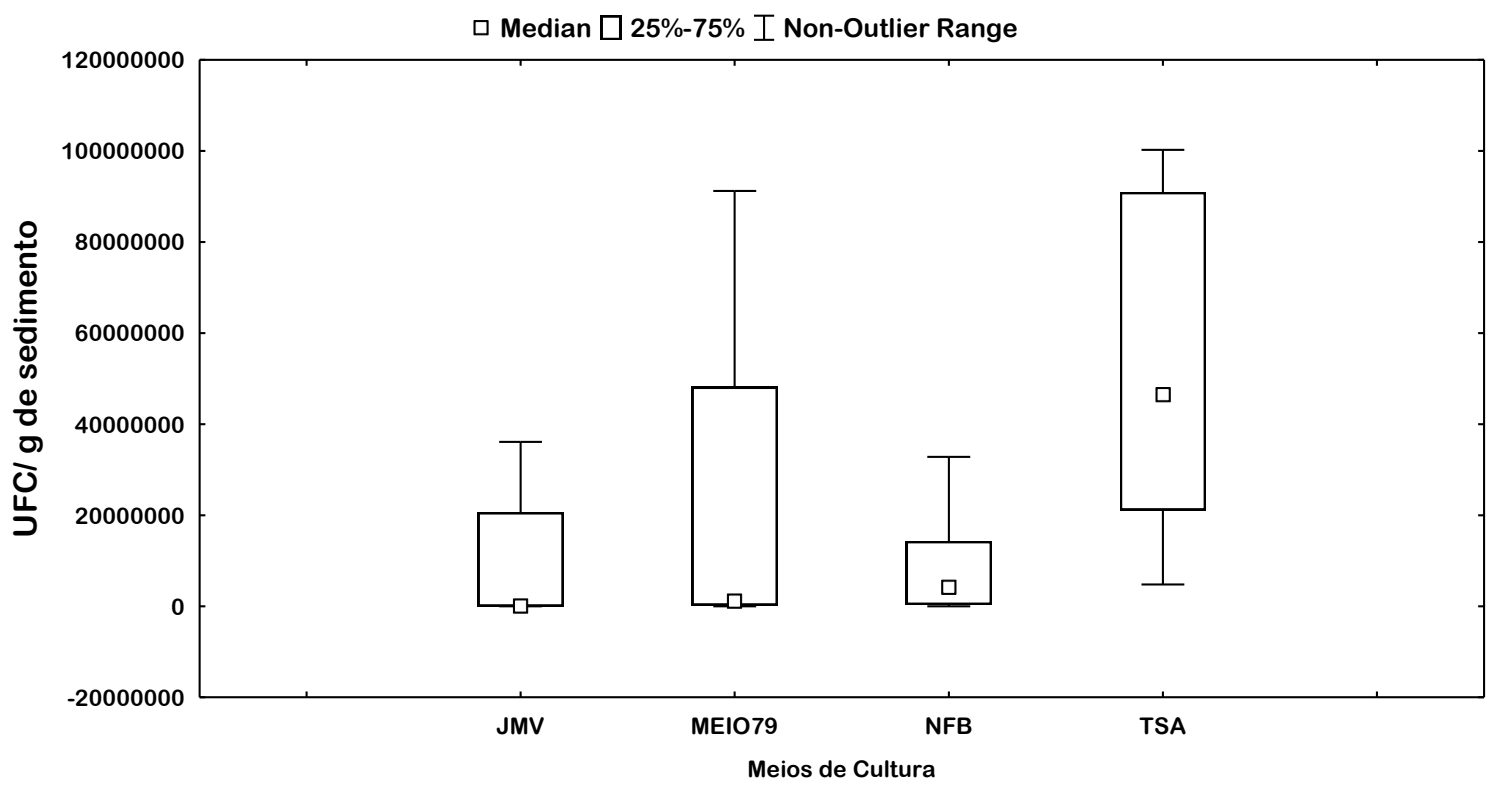

Figura 10. Representação gráfica do Box-plot para análise da densidade entre os meios $(\mathrm{KW}-\mathrm{H}(3 ; 96)=28,3608 ; \mathrm{p}=0,0003)$.

É possível observar na Figura 10 que no meio TSA, o crescimento bacteriano foi melhor representado, e isso pode ser devido ao fato do meio não ser tão seletivo e facilitar o crescimento de bactérias heterotróficas. Porém, não é o mesmo que ocorre nos meios 79, NFB e JMV como observados na Figura 10, que por serem meios específicos para bactérias fixadoras de nitrogênio, não apresentaram um crescimento representativo, em comparação aos meios utilizados. Conforme Döbereiner et al. (1999) os meios 79, NFB e JMV são utilizados para manutenção e isolamento de bactérias fixadoras de nitrogênio do gênero Rhizobium, Azospirillum spp e Burkholderia brasilensis, respectivamente.

A análise morfotintorial de Gram permitiu caracterizar as bactérias processadas de acordo com o tipo de Gram e forma celular. A maioria dos isolados, 59\%, pertencem ao grupo de bastonetes positivos, o que já era previsto, segundo a literatura, devido aos microorganismos pertencentes a este grupo, serem mais resistentes as diversidades bióticas encontradas, como temperatura, disponibilidade de nutrientes, bem como a presença de contaminantes (Tortora et al., 2012).

É possível se verificar com a análise de Gram a presença de endósporos na maioria nos bastonetes Gram-positivos. Em grande parte dos isolados ambientais, principalmente em bactérias do gênero Bacillus e Clostridium, que por uma visão filogenética, a capacidade de produzir endósporos está ligada exclusivamente a uma sublinhagem particular de bactérias Gram-positivas. Apesar disso, a fisiologia das bactérias formadoras de endósporos é bastante diversa, incluindo anaeróbicos, aeróbicos, fototróficos e quimiolitotróficos (Daniel, 1999; Madigan et al., 2004).

Segundo Van Elsas et al. (1998), a limitação da produção bacteriana por diferentes elementos pode acarretar alterações tanto na forma quanto no tamanho bacteriano, e então desconfigurar padrões de forrageiro sobre a bactéria e, por consequência, modificar a estrutura da comunidade bacteriana.

Uma vez que não existe uma chave de identificação bacteriológica para amostras ambientais, foi utilizado o BiochemicalTests for Identificationof Medial Bacteria (MacFaddin, 1980), bem como literatura de Vermelho et al. (2006). 
Assim, por meio dos testes bioquímicos pôde-se identificar as bactérias apenas em nível de família, sendo identificadas treze famílias, algumas presentes em todas as coletas como a família Bacillaceae com 28\%, seguido da família Corynebacteriaceae com 14\%, e da família Propionibacteriaceae com 12\%, e ainda das famílias Micrococcaceae representando $11 \%$ e a família Peptococcaceae com $9 \%$, e $14 \%$ dos isolados foram classificados como não determinados.

Visto que as coletas foram realizadas nos períodos de chuva e seca, e sabe- se que a distribuição da abundância bacteriana está estreitamente relacionada às propriedades do sedimento, bem com as mudanças no fluxo de nutrientes, podemos inferir que os resultados possam estar relacionados com as variações sazonais e outras mudanças ambientais (Carvalho e Paranhos, 2010).

\subsection{Caracterização genotípica- BOX-PCR}

Dentre as 202 colônias identificadas, foram processadas 32 isolados nos testes genéticos. A redução se deve à equalização do esforço de amostragem por período de coleta e pelos testes bioquímicos, tendo em vistaa exclusão de amostras nas quais houve provável contaminação durante o isolamento da colônia, e as cepas de interesse para esta análise foram da família Bacillaceae.

Os perfis de bandas (Figura 11) obtidos para os diferentes isolados pela técnica de BOXPCR foram analisados e o dendograma de similaridade foi construído.
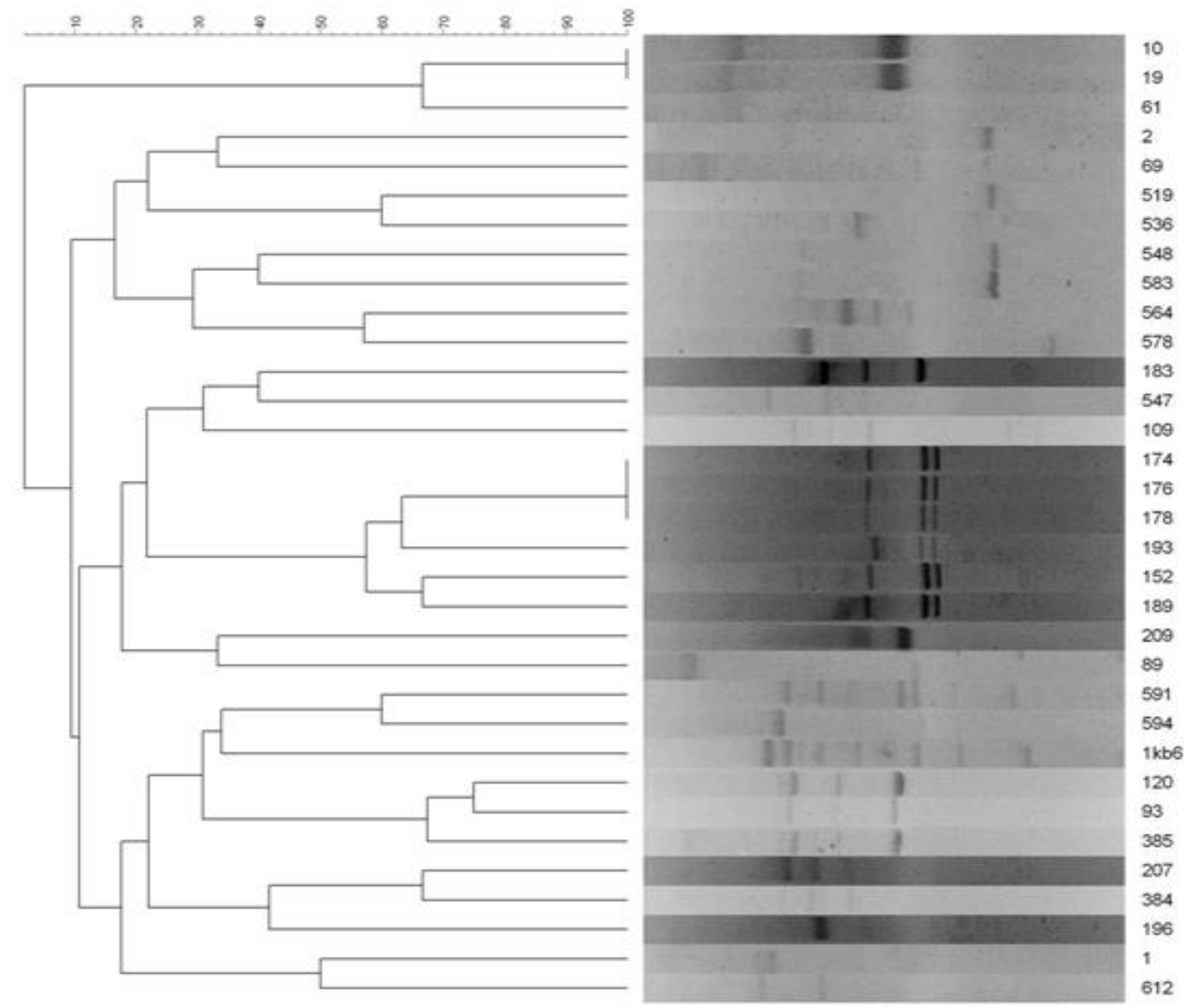

Figura 11. Dendograma de similaridade genética construído com o índice de Jaccard e método de agrupamento UPGMA, mostrando agrupamentos formados entre os isolados analisados pela técnica BOX-PCR. 
Os dados obtidos das amostras ambientais refletem a diversidade da comunidade e as diferenças detectadas entre os locais de amostragem, de acordo com a análise do BOX-PCR. Os resultados estão de acordo com a literatura, os quais apontam que a variabilidade da comunidade bacteriana é influenciada pelos diferentes tipos de micro-ambiente existente em cada tipo de sedimento (Haglud et al., 2003; Pace e Prairie, 2004).

Assim, as cepas 10 e 19 obtidos de pontos amostrais diferentes, sendo a cepa 10 do ponto 6 (Ribeirão dos Cocais) e a cepa 19 do ponto 8 (Barão de Melgaço), possuindo $100 \%$ de similaridade, observou-se ainda que a cepa 61 teve $65 \%$ de similaridade com os isolados 10 e 19 , sendo esta do ponto 6 , sendo os mesmos, isolados da primeira coleta.

Já as cepas 174, 176, 178 e 193, apresentaram 100\% de similaridade, porém as cepas 174 e 178 pertencem ao mesmo espaço amostral, o ponto 8 , já a cepa 176 pertence ao ponto 1 (Cuiabazinho) e a cepa 193 ao ponto 6, ambas isoladas da terceira coleta. E as cepas 93 ponto 1 e 120 ponto 6 apresentaram $70 \%$ de similaridade.

As demais estirpes apresentaram uma dissimilaridade com alta diversidade genética, esses dados podem confirmar a capacidade de autodepuração do rio, uma vez que ainda há uma variabilidade bacteriana, possibilitando a biodegradação de possíveis poluentes.

Holguin et al. (2001) e Melloni et al. (2006) mencionam que estudos de diversidade microbiana são importantes, pois relaciona a variabilidade genética, bem como verifica a distribuição ecológica dos mesmos.

Assim, o uso de técnicas moleculares deve ser estimulado devido ao desenvolvimento de métodos simples e rápidos para a caracterização de populações microbianas, inclusive para estudos em nível de gênero e espécie (Kirk et al., 2004).

\section{CONCLUSÃO}

Com base em técnicas convencionais de microbiologia, foi possível quantificar e verificar a diversidade bacteriana ao longo do gradiente, observando uma maior quantificação de bactérias heterotróficas, observada no meio TSA, ao longo do gradiente amostral. Porém, a utilização de meios específicos não propôs resultados satisfatórios, devido ao fato de ter encontrado bactérias com as mesmas características tanto morfológicas quanto fisiológicas nestes meios, e suas características e composição deveriam ser mais seletivos.

As análises bioquímicas mostraram uma diversidade significativa das famílias bacterianas, principalmente da Bacillaceae, formada por bacilos esporulados.

A análise molecular por BOX-PCR mostrou ser uma técnica molecular eficiente, uma vez que é uma técnica rápida, de fácil execução e altamente discriminatória, verificando uma diversidade genética da comunidade bacteriana, obtendo uma riqueza de espécies entre os pontos amostrais, observando que a bacia do rio Cuiabá, ainda apresenta características de autodepuração, apesar de em alguns pontos apresentarem atividades agro-industriais.

\section{REFERÊNCIAS}

AGÊNCIA NACIONAL DAS ÁGUAS - ANA (Brasil). Relatório final: avaliação dos mecanismos financeiros para o gerenciamento sustentável da bacia piloto do rio Cuiabá. ANA/GEF/PNUMA/OEA. Brasília, 2003.

AGÊNCIA NACIONAL DAS ÁGUAS - ANA (Brasil). Guia nacional de coleta e preservação de amostras-água, sedimento, comunidades aquáticas e efluentes líquidos. Brasília, 2011.

ANDRADE, L. N. Autodepuração dos corpos d'água. Revista da Biologia, v. 5, Dez. 2010. 
BEGON, M.; TOWNSEND, C. R.; GARPER, J. L. Ecologogy: from individuals to ecosystems. 4. ed. Liverpool: School of Biological Sciences, The University of Liverpool, 2006. 765p.

CALHEIROS, D. F. Determinação de impactos e conservação dos recursos hídricos na bacia do Alto Paraguai. 2008. In: __ . Disponível em : http://www.agronline.com.br/ artigos/artigo.php?id=310. Acesso em: 10 maio 2011.

CARVAlHO, K. D. C.; PARANHOS, R. Análise de abundância bacteriana no estudo da ecologia microbiana de sedimentos marinhos. Oecologia Australis, v. 14, n. 2, p. 415436, jun. 2010. http://dx.doi.org/10.4257/oeco.2010.1402.06

COSTA, R. S. Variabilidade e diversidade genética de comunidades bacterianas associadas a rizosfera de milho (Zeamays L. Merril) em um agrossistema do Rio de Janeiro. 2001. 127 p. Dissertação (Mestrado) - Universidade Federal do Rio de Janeiro, Rio de Janeiro, 2001.

CUIABÁ. Secretaria do Meio Ambiente. Relatório de monitoramento da qualidade das águas da sub-bacia do Rio Cuiabá/MT. Cuiabá, 2005.

DANIEL, R. C. Microbial physiology and metabolism. 2. ed. Star Publishing, 1999.

DÖBEREINER, J.; ANDRADE, V. O.; BALDANI, V. L. D. Protocolos para preparo de meios de cultura da Embrapa Agrobiologia. Seropédica: EMBRAPA, 1999.

EÇA, L. P. M. Biologia molecular: apresentação de algumas técnicas utilizadas na biologia molecular. Revinter, 2004. p.145-155.

EMPRESA BRASILEIRA DE PESQUISA AGROPECUÁRIA - EMBRAPA. Centro Nacional de Pesquisa de Soja. Ecologia, manejo e adubação da soja. Londrina, 1979. (Circular técnica, 2)

EMPRESA BRASILEIRA DE PESQUISA AGROPECUÁRIA - EMBRAPA. Centro Nacional de Pesquisa de Solos. Manual de métodos de análise de Solo. 2. ed. Seropédica, 1997.

GIMENES, K. Z.; CUNHA-SANTINO, M. B.; BIACHINI JR., I. Decomposição de matéria orgânica alóctone e autóctone em ecossistemas aquáticos. Revista Oecologia Australis, v. 14, n. 4, p. 1036-1073, dez. 2010. http://dx.doi.org/10.4257/oeco.2010.1404.13

HAGLUND, A. L.; LANTZ, P.; TORNBLOM, E.; TRANVIK, L. Depth distribution of active bacteria and bacterial activity in lake sediment. FEMS Microbiology Ecology, 46. p. 31-38, 2003. http://dx.doi.org/10.1016/S0168-6496(03)00190-9

HOLGUIN, G.; VAZQUEZ, P.; BASHAN, Y. The role of sediment microorganisms in the productivity, conservation, and rehabilitation of mangrove ecosystems: an overview.

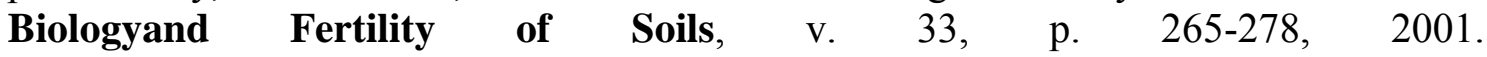
http://dx.doi.org/10.1007/s003740000319

KIRK, J.; BEAUDETTE, L.; HART, M.; MOUTOGLIS, P. Methods of studying soil microbial diversity. Journal of Microbiological Methods, v. 58, p. 169-188, 2004. http://dx.doi.org/10.1016/j.mimet.2004.04.006

MACFADDIN, J. F. Biochemical tests for identification of medical bacterial. 2. ed. Baltimore : Williams \& Wilkins, 1980. 
MADIGAN, M. T.; MARTINKO, J. M.; PARKER, J. Microbiologia de Brock. 10. ed. São Paulo: Pearson; Prentice Hall, 2004.

MELLONI, R. R.; NÓBREGA, S. A.; MOREIRA F. M. S.; SIQUEIRA J. O. Densidade e diversidade fenotípica de bactérias diazotróficas endofíticas em solos de mineração de bauxita, em reabilitação. Revista Brasileira Ciência do Solo, v. 28, v. 1, p. 85-93, 2006. http://dx.doi.org/10.1590/S0100-06832004000100009

MINELLA, J. P. G.; MERTEN, G. H.; REICHERT, J. M.; SANTOS, D. R. Identificação e implicações para a conservação do solo das fontes de sedimentos em bacias hidrográficas. Revista Brasileira Ciência do Solo, v. 31, n. 6, p. 1637-1646, 2007. http://dx.doi.org/10.1590/S0100-06832007000600039

NEDER R. N. M. Microbiologia: manual de laboratório. São Paulo: Nobel, 1992. 138p.

ODUM H. T. Environment, power and society for the twenty-first century: the hierarchy of energy. New York: Columbia University Press, 2007. 432p.

PACE, M. L.; PRAIRIE, Y. T. Respiration in aquatic ecosystems: respiration in lakes. Oxford: Oxford University Press, 2004.

PERREIRA, J. C.; NEVES, M. C. P.; DROZDOWICZ. Dinâmica das populações bacterianas em solos de cerrados. EMBRAPA, v. 34, n. 5, p. 801-811, maio 1999.

REIS, M. R.; SILVA, A. A.; COSTA, M. D.; GUIMARÃES, A. A.; FERREIRA, E. A. SANTOS, J. B. et al. Atividade microbiana em solo cultivado com cana-de-açúcar após aplicação de herbicida. Planta Daninha, Viçosa-MG, v. 26, n. 2, p. 323-331, 2008.

REIS JUNIOR, F. B. R.; MENDES, I. C.; TEIXEIRA, K. R. S. REIS, V. M. Uso de ferramentas moleculares em estudos da diversidade de micro-organismos do solo. Planaltina: EMBRAPA, 2002.

RHEINHEIMER, D. S.; ANGHINONI, I.; CONTE, E. Sorção de fósforo em função do teor inicial e de sistemas de manejo de solos. Revista Brasileira de Ciências do Solo, v. 27, n. 1, p. 41-49, 2003. http://dx.doi.org/10.1590/S0100-06832003000100005

SHINMA, E. A. Avaliação da qualidade das águas dos rios da Bacia Hidrográfica do Alto Paraguai-Pantanal. 2004. Dissertação (Mestrado) - Universidade do Mato Grosso do Sul, Campo Grande, 2004.

TAMMERT, H.; OLLI, K.; STURLUSON, M.; HODAL, H. Bacterial biomass and activity in the marginal ice zone of the northern Barents Sea. Deep-Sea Research Part II: Tropical Studies in Oceanography, v. 55, p. 2199-2209, 2008. http://dx.doi.org/10.1016/j.dsr2.2008.05.011

TORTORA, G. J.; FUNKE, B. R.; CASE, C. L. Microbiologia. 10. ed. Porto Alegre: Artemed, 2012.

VAN ELSAS, J. D.; DUARTE, G. F.; ROSADO, A. S.; SMALLA, K. Microbiological and molecular biological methods for monitoring microbial inoculants and their effects in the soil environment. Journal of Microbiological Methods, v. 32, n. 2, p. 133-154, 1998. http://dx.doi.org/10.1016/S0167-7012(98)00025-6

VERMElHO, A. B.; COELHO, R. R. R.; PEREIRA, A. F. Práticas de microbiologia. Rio de Janeiro: Gaunabara Koogan, 2006. 
VERSALOVIC, J.; SCHNEIDER, M.; BRUIJN, F. J.; LUPSKIW, J. R. Genomic fingerprinting of bacteria using repetitive sequence-based polymerase chain reaction. Methods in Molecular and Cellular Biology, v. 5, p. 25-40, 1994.

VON SPERLING, M. Princípios do tratamento biológico de águas residuárias. 3. ed. Belo Horizonte: Departamento de Engenharia Sanitária e Ambiental/UFMG, 2005.

VREDE, K. Nutrient and temperature limitation of bacterioplankton growth in temperate lakes. Microbial Ecology, v. 49, p. 245-256, 2005. http://dx.doi.org/10.1007/s00248004-0259-4

XAVIER, F. A. S.; MAIA, S. M. F.; OLIVEIRA, T. S.; MENDONÇA, E. S. Biomassa microbiana e matéria orgânica leve em solos sob sistemas agrícolas orgânico e convencional na Chapada da Ibiapaba-CE. Revista Brasileira de Ciência do Solo, v. 30, p. 247-258, 2006. http://dx.doi.org/10.1590/S0100-06832006000200006 


Ambiente \& Água - An Interdisciplinary Journal of Applied Science
ISSN 1980-993X - doi:10.4136/1980-993X
www.ambi-agua.net
E-mail: ambi-agua@agro.unitau.br

\title{
Resíduos de pesticidas em sedimento de fundo de rio na Bacia Hidrográfica do Rio Cuiabá, Mato Grosso, Brasil
}

\author{
doi: 10.4136/ambi-agua.1263 \\ Received: 20 Dec. 2013; Accepted: 25 Feb. 2014 \\ Juliana Possavatz $^{1 *}$; Peter Zeilhofer ${ }^{2}$; Alicio Alves Pinto
André Luiz Tives
; Eliana Freire Gaspar de Carvalho Dores $^{3}$ \\ Universidade Federal de Mato Grosso - Cuiabá, MT, Brasil \\ ${ }^{1}$ Programa de Pós-Graduação em Recursos Hídricos \\ ${ }^{2}$ Departamento de Geografia \\ ${ }^{3}$ Departamento de Química \\ *Autor correspondente: e-mail: julianapossavatz@yahoo.com.br, \\ zeilhoferpeter@gmail.com, alicio_pinto@hotmail.com, andretives52@gmail.com, eliana@ufmt.br
}

\section{RESUMO}

O rio Cuiabá é um importante tributário do rio Paraguai, cuja bacia é de grande importância por agasalhar o Pantanal, a maior área úmida do planeta. A base econômica da bacia hidrográfica do rio Cuiabá é a produção agrícola e pecuária que, para manter elevada produtividade, requer grandes quantidades de insumos agrícolas como os pesticidas que, podem atingir diversos ambientes devido aos processos de dispersão que ocorrem após sua introdução no ambiente. Os sedimentos desempenham importante papel para a caracterização da poluição de rios devido a seu potencial de acumulação de poluentes. Este estudo objetivou avaliar a contaminação por pesticidas usados nas lavouras plantadas na bacia do rio Cuiabá, MT. Para tanto, amostras de sedimento de fundo foram coletadas mensalmente de agosto de 2011 a julho de 2012. Para a determinação dos pesticidas atrazina, cipermetrina, clorpirifós, endossulfam ( $\alpha, \beta$ e seu metabólito endossulfam sulfato), lambda-cialotrina, malationa, metolacloro, metribuzim, parationa metílica, permetrina e trifuralina no sedimento utilizou-se método multirresíduo que consiste na extração sólido-líquido por agitação mecânica seguida de purificação por extração líquido-líquido e identificação e quantificação por cromatografia a gás acoplada a espectrometria de massas. Resíduos de pesticidas foram identificados em amostras coletadas em agosto e setembro de 2011 e janeiro, fevereiro, abril e julho de 2012, em concentrações variando de 5,7 a 79,3 $\mu \mathrm{g} \mathrm{kg}^{-1}$. Embora a frequência de detecção tenha sido baixa, esses resultados indicam que há potencial de transporte de pesticidas usados na bacia do rio Cuiabá e seus tributários atingindo o Pantanal.

Palavras-chave: contaminação, escoamento superficial, recursos hídricos.

\section{Pesticide residue in bottom sediment in the Cuiabá River watershed, Mato Grosso, Brazil}

\section{ABSTRACT}

The Cuiabá River is a major tributary of the Paraguay River; its basin is of great importance and encloses the Pantanal, the world's largest wetland. The economic base in the 
Cuiabá River basin is agriculture and livestock production. In order to maintain high productivity, large amounts of agricultural inputs such as pesticides are required, which may reach various environments due to several dispersion processes that occur after their introduction into the environment. Sediments play an important role in the characterization of pollution of rivers and lakes due to their potential to accumulate pollutants. The present study aimed to evaluate contamination by pesticides used on crops planted in the Rio Cuiaba basin in Mato Grosso. Accordingly, samples of bottom sediment were collected monthly from August 2011 to July 2012. We used a multi-residue method, consisting of solid-liquid extraction by mechanical agitation and purification by liquid-liquid extraction. Identification and quantification was done by gas chromatography/mass spectrometry (GC/MS) for the determination of atrazine, cypermethrin, chlorpyrifos, endosulfan $(\alpha, \beta$ and sulfate), lambdacyhalothrin, malathion, metolachlor, metribuzin, methyl parathion, permethrin and trifuralin. Pesticide residues were identified in the samples collected in August and September 2011 and in January, February, April and July 2012, at concentrations ranging from 5.7 to $79.3 \mu \mathrm{g} \mathrm{kg}^{-1}$. Although the frequency of detection was low, these results show that there is potential for the transport of pesticides used in the Cuiabá River basin and its tributaries reaching the Pantanal.

Keywords: contamination, runoff, water resources.

\section{INTRODUÇÃO}

O uso de pesticidas vem crescendo globalmente, com centenas de diferentes princípios ativos desenvolvidos para uso agrícola e não agrícola. Segundo a Agência Nacional de Vigilância Sanitária (ANVISA, 2012), o mercado brasileiro de pesticidas cresceu 190\%, ritmo muito mais acentuado do que o registrado pelo mercado mundial (93\%) entre 2000 e 2010 . De acordo com essa mesma agência, somente na safra 2010/2011 o consumo de pesticidas no Brasil atingiu a marca de 936 mil toneladas. Este elevado consumo é decorrente das grandes áreas de atividade agrícola que, no caso da região Centro-Oeste, aumentou vertiginosamente nas décadas de 70 e 80 em decorrência da ocupação dos Cerrados (Spadotto e Gomes, 2005). Contudo, estudos em várias regiões do país e do mundo evidenciam os problemas relacionados aos efeitos adversos dessas substâncias para a saúde humana e o meio ambiente (Baek et al., 2011; Cabrera et al., 2008; Delgado-Moreno et al., 2011; Malik et al., 2007; Miglioranza et al., 2013; Nogueira et al., 2012).

A bacia hidrográfica do rio Cuiabá abrange, total ou parcialmente, 29 municípios, sendo 25 localizados no Estado do Mato Grosso e 4 no Estado do Mato Grosso do Sul. O rio Cuiabá é um dos principais afluentes do rio Paraguai, cuja bacia é de grande importância nacional e internacional, por abrigar o Pantanal, uma das maiores extensões úmidas do planeta (Agência Nacional de Águas, 2003). Dentre as atividades econômicas desenvolvidas ao longo da área de drenagem dos rios Cuiabá e São Lourenço a agricultura tem papel de destaque, pois representa a base econômica da região, principalmente no cultivo da soja, algodão e milho (Mato Grosso, 2005), que vêm crescendo nos últimos 30 anos, sendo que entre os anos de 2008 e 2012, apresentou um aumento de 32,4\% (Instituto Brasileiro de Geografia e Estatística, 2013). Para manter a alta produtividade, o manejo dessas culturas requer uma elevada quantidade de insumos agrícolas, como os pesticidas que, de acordo com a maneira como são aplicados, pode sofrer diversos processos de dispersão, atingindo distintas matrizes ambientais, ameaçando assim, a sustentabilidade dos recursos hídricos da região (Dores e DeLamonica-Freire, 2001; Ribeiro et al., 2013).

Os sedimentos de fundo de rio desempenham uma importante função no processo de caracterização da poluição dos rios e lagos. A qualidade da água superficial é afetada pela 
qualidade do sedimento sobre o qual ela atravessa devido aos processos de equilíbrio que se estabelece entre água e sedimento. Além disso, os sedimentos são considerados o depósito final de muitas classes de contaminantes antropogênicos no ambiente (Jaffé, 1991, Gebremarian et al., 2012) e a dinâmica de algumas espécies químicas faz com que os sedimentos atuem como "estoque" e possíveis fontes de poluição, pois os contaminantes (espécies inorgânicas ou orgânicas) não permanentemente fixados por eles, podem ser disponibilizados para a coluna d'água devido a mudanças em parâmetros como $\mathrm{pH}$, potencial redox ou ação de microrganismos. Deste modo, podem ser importante foco de contaminantes, mesmo quando as fontes de contaminações atmosféricas e/ou terrestres já tenham sido controladas ou eliminadas (Rocha et al., 2009). Alguns trabalhos têm demonstrado que sedimentos contaminados com poluentes orgânicos persistentes tais como pesticidas organoclorados e PCBs são focos de contaminação das águas (Bradshaw et al., 2012; Granberg et al., 2008). Entretanto, a falta de dados consistentes de adsorção/dessorção dos pesticidas menos persistentes em sedimentos dificulta a previsão do comportamento destas substâncias neste compartimento (Gebremarian et al., 2012).

Considerando o intenso uso de pesticidas na bacia do rio Cuiabá, a importância desta bacia para o Pantanal e ainda a capacidade dos sedimentos de fundo de acumular contaminantes, o presente estudo teve como objetivo avaliar a contaminação por pesticidas usados nas culturas plantadas ao longo da área de drenagem do Rio Cuiabá e São Lourenço no Estado de Mato Grosso, em sedimentos de fundo dos rios. De acordo com um levantamento prévio junto ao Instituto de Defesa Agropecuária de Mato Grosso (INDEA/MT), órgão que controla as guias de comercialização, foram selecionados para determinação os seguintes princípios ativos: atrazina, metribuzim, parationa metílica, malationa, metolacloro, clorpirifós, endosulfam alfa, endosulfam beta, sulfato de endosulfam, lambda-cialotrina, permetrina e cipermetrina sendo estes identificados e quantificados por cromatografia a gás acoplada com espectrometria de massa (CG/EM).

\section{MATERIAL E MÉTODOS}

\section{1. Área de Estudo}

A bacia hidrográfica do rio Cuiabá está localizada entre as coordenadas geográficas $14^{\circ} 18^{\prime}$ e $17^{\circ} 00^{\prime}$ de latitude Sul e $54^{\circ} 40^{\prime}$ e $56^{\circ} 55^{\prime}$ de longitude Oeste, no Estado do Mato Grosso, e seus principais afluentes são os rios: Marzagão, Manso, Acorizal, Coxipó-Açú, Coxipó, Coxipó-Mirim, Aricá Açú, Aricá Mirim, Mutum e São Lourenço pela margem esquerda, e pela margem direita o Chiqueirão, Jangada, Espinheiro e Piraim (Mato Grosso, 2010).

O rio São Lourenço nasce no município de Campo Verde, banha os estados de Mato Grosso e Mato Grosso do Sul e deságua no Pantanal, sendo um dos principais afluentes da Bacia do rio Paraguai, englobando os municípios matogrossenses de Jaciara, Juscimeira, São Pedro da Cipa, Rondonópolis, Poxoréu, Dom Aquino e Campo Verde (Mato Grosso, 2008). A área de estudo no presente trabalho corresponde à bacia hidrográfica do rio Cuiabá, considerando, o rio São Lourenço como sendo uma sub-bacia do rio Cuiabá. Dessa maneira foram selecionados também para o estudo alguns dos principais afluentes do São Lourenço, são eles: o rio Tenente Amaral, Vermelho e Ponte de Pedra.

As nascentes dos rios Cuiabá e São Lourenço estão localizadas em áreas de Planalto enquanto seu exutório, no rio Paraguai, ocorre em área de planície, no Pantanal. Assim, essa bacia apresenta características tanto de rio de planalto como de planície, e as atividades desenvolvidas nas áreas mais altas podem causar impactos nas áreas baixas. 
Com relação à pluviosidade, que está fortemente relacionada ao transporte dos pesticidas pelo processo de lixiviação ou de escoamento superficial, a região caracteriza-se por possuir dois períodos bastante distintos. O período seco se estende de maio a setembro com precipitações mensais geralmente abaixo de $100 \mathrm{~mm}$, enquanto entre $70 \%$ e $80 \%$ da precipitação são concentrados no período chuvoso entre os meses de novembro a abril. Os valores anuais médios totalizam entre mais do que $2000 \mathrm{~mm}$ em algumas áreas do Planalto e menos do que $1200 \mathrm{~mm}$ na parte baixa da bacia.

As principais culturas na bacia estudada correspondem a soja, milho e algodão, que vêm crescendo nos últimos 30 anos, sendo que entre os anos de 2008 e 2012 apresentaram um aumento de $32,4 \%$, superior ao crescimento em área plantada dessas mesmas culturas registrado no país e na região Centro-Oeste (Tabela 1).

Tabela 1. Área plantada total das principais culturas nos municípios pertencentes à bacia do rio Cuiabá.

\begin{tabular}{l|cccccc}
\hline $\begin{array}{c}\text { Município/ } \\
\text { região }\end{array}$ & $\mathbf{2 0 0 8}$ & $\mathbf{2 0 0 9}$ & $\mathbf{2 0 1 0}$ & $\mathbf{2 0 1 1}$ & $\mathbf{2 0 1 2}$ & $\begin{array}{c}\text { Aumento entre } \\
\mathbf{2 0 0 8 - 2 0 1 2} \\
\mathbf{( \% )}\end{array}$ \\
\hline Brasil & 52.959 .308 & 53.557 .841 & 53.396 .971 & 56.185 .016 & 57.682 .184 & 8,92 \\
Centro-Oeste & 16.082 .019 & 16.211 .688 & 16.954 .068 & 18.166 .292 & 20.223 .292 & 25,75 \\
& 8.724 .559 & 8.649 .721 & 9.298 .438 & 9.820 .360 & 11.187 .385 & 28,22 \\
Mato-Grosso & 1.242 .318 & 1.333 .608 & 1.469 .411 & 1.374 .171 & 1.644 .849 & 32,4 \\
\hline $\begin{array}{l}\text { Bacia do rio } \\
\text { Cuiabá * }\end{array}$ & & & & & & \\
\hline
\end{tabular}

Fonte: IBGE, 2013. *valor estimado a partir do total dos 25 municípios inseridos na bacia.

\subsection{Amostragem}

Para este estudo foram selecionados nove pontos de amostragem de sedimento de fundo, conforme indicado na Figura 1 e Tabela 2, em que foram abrangidas áreas de planalto e planície. As amostras foram coletadas mensalmente entre os meses de agosto de 2011 e julho de 2012, contabilizando um total de 216 amostras. Essas amostras com massa aproximada de $1 \mathrm{~kg}$ foram coletadas usando draga de Petersen e armazenadas em sacolas plásticas previamente identificadas e transferidas para caixas de alumínio na chegada ao laboratório. Todas as amostras foram transportadas até o laboratório em caixas térmicas com gelo e armazenadas congeladas a $-20^{\circ} \mathrm{C}$ até o momento das análises. A seleção dos pontos de amostragem foi feita de maneira que se tivesse uma representatividade do curso médio alto na Depressão Cuiabana, na cidade de Rosário Oeste (CBA 01), a jusante da área metropolitana de Cuiabá/Várzea Grande próximo à cidade de Santo Antônio do Leverger (CBA 02), da área de Planalto, nas cidades de Jaciara e Rondonópolis (SL 01, SL 02 e SL 03), região esta onde há a maior influência agrícola e, por último, no Pantanal, nas proximidades de Porto Cercado e em corixos, na área de planície (CBA 03, CBA 04, CBA 05 e CBA 06).

Para selecionar as moléculas a serem analisados, foi feito um levantamento dos pesticidas aplicados nos municípios pertencentes à área estudada, com base no banco de dados do Instituto de Defesa Agropecuária de Mato Grosso (INDEA/MT) referente aos anos de 2008 e 2009 (últimos dados disponíveis), a partir do qual se verificaram quais pesticidas estavam sendo utilizados em maior frequência e quantidade. 


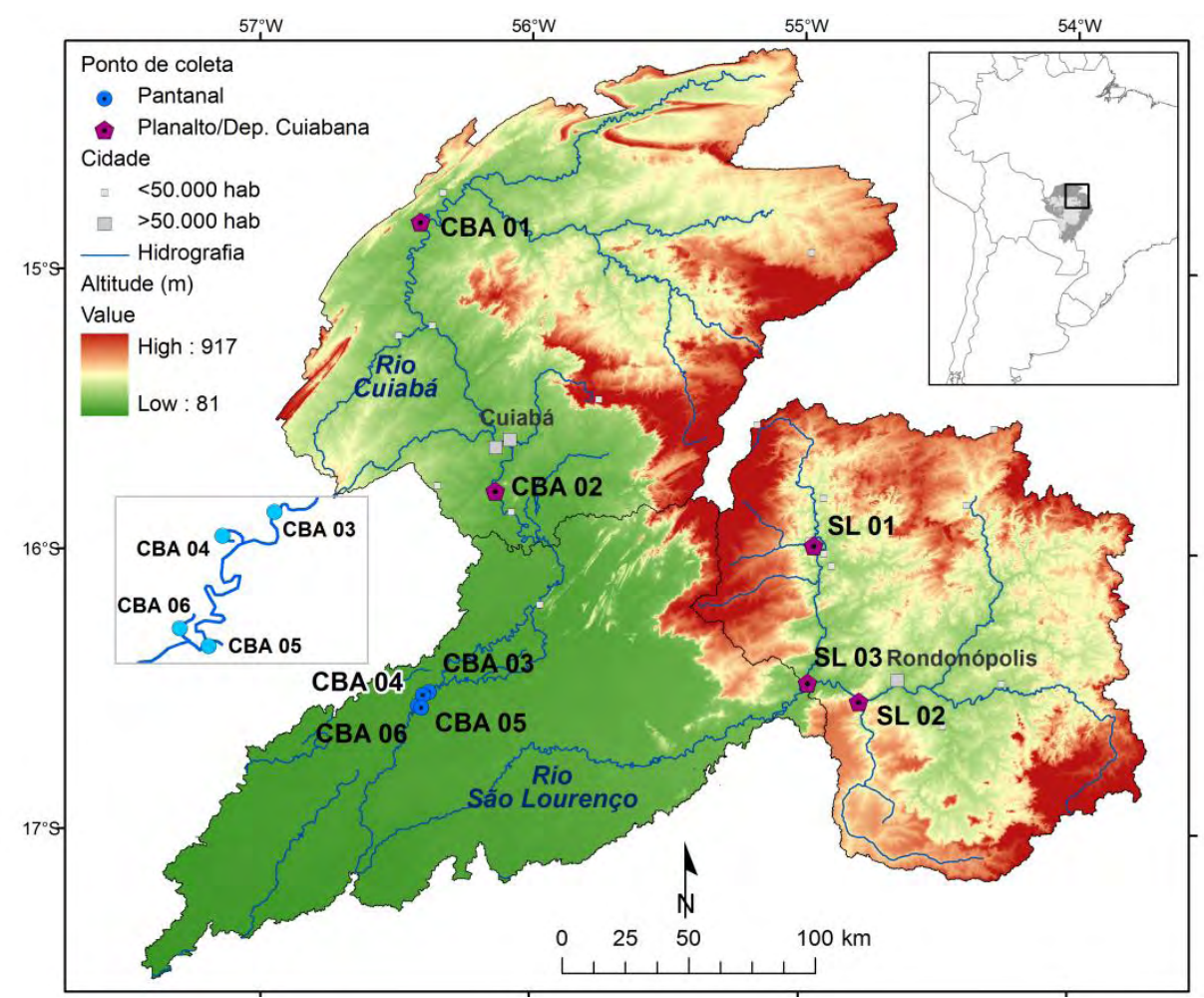

Figura 1. Mapa planialtimétrico da bacia do Rio Cuiabá com indicação dos pontos de coleta de amostras de sedimento de fundo.

Tabela 2. Coordenadas dos pontos de amostragem.

\begin{tabular}{|c|c|c|c|}
\hline Ponto & Identificação do ponto & Região & $\begin{array}{l}\text { Coordenadas } \\
\text { Geográficas }\end{array}$ \\
\hline CBA 01 & Rio Cuiabá (Ponte em Rosário Oeste) & Curso médio alto & $\begin{array}{l}\text { S } 14^{\circ} 49^{\prime} 58,9^{\prime \prime} \\
\text { W } 56^{\circ} 24^{\prime} 53,9^{\prime \prime}\end{array}$ \\
\hline CBA 02 & Rio Cuiabá (Santo Antônio) & $\begin{array}{l}\text { Curso médio } \\
\text { baixo }^{1}\end{array}$ & $\begin{array}{l}\text { S } 15^{\circ} 47^{\prime} 43,6^{\prime \prime} \\
\text { W } 56^{\circ} 07^{\prime} 38,6^{\prime \prime}\end{array}$ \\
\hline SL 01 & Rio Tenente Amaral (Jaciara) & Planalto & $\begin{array}{l}\text { S } 15^{\circ} 58^{\prime} 58,8^{\prime \prime} \\
\text { W } 54^{\circ} 57^{\prime} 17,5^{\prime \prime}\end{array}$ \\
\hline SL 02 & Rio Ponte de Pedra (Rondonópolis) & Planalto & $\begin{array}{l}\text { S } 16^{\circ} 32^{\prime} 28,6^{\prime \prime} \\
\text { W } 54^{\circ} 46^{\prime} 53,8\end{array}$ \\
\hline SL 03 & $\begin{array}{l}\text { Rio São Lourenço (Confluência do rio } \\
\text { Vermelho com o rio São Lourenço) }\end{array}$ & Planalto & $\begin{array}{l}\text { S } 16^{\circ} 28^{\prime} 36,4^{\prime \prime} \\
\text { W } 54^{\circ} 58^{\prime} 39,4^{\prime \prime}\end{array}$ \\
\hline CBA 03 & Rio Cuiabá (Porto Cercado - Pantanal) & Planície & $\begin{array}{l}\text { S } 16^{\circ} 30^{\prime} 52,7^{\prime \prime} \\
\text { W } 56^{\circ} 22^{\prime} 31,8^{\prime \prime}\end{array}$ \\
\hline CBA 04 & $\begin{array}{l}\text { Rio Cuiabá (Corixo Antonio Alves - } \\
\text { Pantanal) }\end{array}$ & Planície & $\begin{array}{l}\text { S } 16^{\circ} 31 ' 26,4^{\prime \prime} \\
\text { W } 56^{\circ} 23 ' 56,7^{\prime \prime}\end{array}$ \\
\hline CBA 05 & Rio Cuiabá (Corixo do Moquem - Pantanal) & Planície & $\begin{array}{l}\text { S } 16^{\circ} 34^{\prime} 11.0^{\prime \prime} \\
\text { W } 56^{\circ} 24^{\prime} 13,11^{\prime \prime}\end{array}$ \\
\hline CBA 06 & Rio Cuiabá (Corixão - Pantanal) & Planície & $\begin{array}{l}\text { S } 16^{\circ} 33^{\prime} 47.7^{\prime \prime} \\
\text { W } 56^{\circ} 25^{\prime} 04.3^{\prime \prime}\end{array}$ \\
\hline
\end{tabular}

Nota: ${ }^{1}$ Este ponto está localizado no início da área de planície abaixo dos dois grandes centros urbanos de Cuiabá e Várzea Grande. 


\subsection{Reagentes e Padrões}

Foram utilizados os seguintes solventes e reagentes: sulfato de sódio anidro (J. T. Baker, ACS); lã de vidro (CAAL); água ultra-purificada (Milli-Q a 18,0 M $\Omega \mathrm{cm}^{-1}$ ); n-Hexano (95\% Mallinckrodt Chemicals, para cromatografia); acetona (99,5\%, M Tedia, grau HPLC); metanol e diclorometano (99,9\%, M Tedia, grau HPLC); acetato de etila $(99,6 \%$, Mallinckrodt Chemicals); tolueno (99,8\%, Mallinckrodt Chemicals, grau HPLC). Os padrões analíticos de alta pureza $(>95,4 \%)$ dos pesticidas estudados (atrazina, cipermetrina, clorpirifós, endosulfam ( $\alpha, \beta$ e sulfato), lambda cialotrina, malationa, metolacloro, metribuzim, parationa metílica, permetrina e trifuralina) e do padrão interno fenantreno D-10, foram adquiridos das empresas Dr. Ehrenstorfer Gmbh (Augsburg, Alemanha), SigmaAldrich Laborchemikalien GmbH (Riedel-de-Haen) (Seelze, Alemanha) e Sigma-Aldrich Chemie GmbH (Steinheim, Alemanha).

\subsection{Método de extração de resíduos de pesticidas em sedimento por CG/EM}

A extração dos pesticidas das amostras de sedimento de fundo foi realizada seguindo o procedimento descrito por Laabs et al. (2002), otimizado por Miranda (2008). Para tanto, pesaram-se 20,0 g de amostra úmida em Erlenmeyer, aos quais foram adicionados $50 \mathrm{~mL}$ da mistura de solventes acetona, acetato de etila e água, na proporção de $2: 2: 1(\mathrm{v} / \mathrm{v} / \mathrm{v})$ e submetido à agitação mecânica por 4 horas. Em seguida, o extrato foi filtrado usando papel de filtro faixa média e concentrado em evaporador rotatório a $42{ }^{\circ} \mathrm{C}$, rotação de $90 \mathrm{rpm}$ e pressão de 300 mbar. Após evaporação da fase orgânica, foram adicionados $30 \mathrm{~mL}$ de solução saturada de cloreto de sódio ao extrato concentrado, o qual foi submetido a extração líquidolíquido com diclorometano $(1 \times 30 \mathrm{~mL}$ mais $2 \times 25 \mathrm{~mL})$. A fase contendo diclorometano foi filtrada em funil de vidro, contendo sulfato de sódio anidro e lã de vidro, sendo posteriormente purificado com alumina e florisil.

Para a purificação condicionou-se, com hexano, $1,0 \mathrm{~g}$ de alumina e $1,0 \mathrm{~g}$ de florisil empacotados em cartucho de vidro, ativando-se as fases, previamente, por meio de aquecimento em mufla a $600{ }^{\circ} \mathrm{C}$ durante 4 horas, sendo em seguida adicionados $0,06 \mathrm{~g}$ e $0,1 \mathrm{~g}$ de água deionizada para cada $1,0 \mathrm{~g}$ de fase, respectivamente. Após a transferência do extrato para a coluna, os pesticidas foram eluídos com $10 \mathrm{~mL}$ de hexano e $10 \mathrm{~mL}$ da mistura de solventes, hexano e acetato de etila, na proporção de 4:1 (v/v). O eluato foi concentrado em evaporador rotatório $\left(45^{\circ} \mathrm{C}, 80 \mathrm{rpm}\right.$ e 400 mbar) e retomado com alíquotas de tolueno em frasco de autoamostrador (vials) contendo $100 \mu \mathrm{L}$ do padrão interno fenantreno D-10 $\left(1 \mu \mathrm{g} \mathrm{mL}{ }^{-1}\right)$ e armazenado em refrigerador $\left(-4^{\circ} \mathrm{C}\right)$ até análise por CG/EM.

Os procedimentos de extração foram feitos em duplicata e os resultados $\left(\mu \mathrm{g} \mathrm{kg}^{-1}\right.$ de peso seco) apresentados como a média dos valores determinados. A determinação do peso seco das amostras foi realizada por gravimetria para correção do resultado final. A cada lote de amostras adicionava-se uma amostra controle (isenta da matriz) visando controlar qualquer possível interferente decorrente do procedimento de extração.

\subsection{Condições Cromatográficas}

Para a separação e identificação dos analitos foi utilizado um cromatógrafo a gás (modelo HP 6890) com injetor automático (modelo 7683B series), acoplado a um espectrômetro de massa (modelo HP 5973), equipado com coluna HP 19091-433 com fase HP-5 (5\% de fenil metil siloxano, $30,0 \mathrm{~m} \times 250 \mu \mathrm{m}$ d.i. $\times 0,25 \mu \mathrm{m}$ de espessura do filme). Para a separação adequada dos analitos no sistema $\mathrm{CG} / \mathrm{EM}$, foi utilizada a seguinte programação otimizada de temperatura do forno: temperatura inicial de $92^{\circ} \mathrm{C}$ mantida por $2,5 \mathrm{~min}$, em seguida rampa de $15^{\circ} \mathrm{C} \mathrm{m^{-1 }}$ até $175^{\circ} \mathrm{C}$ mantida por $13 \mathrm{~min}$, e rampa de $20^{\circ} \mathrm{C} \mathrm{min}{ }^{-1}$ até $280{ }^{\circ} \mathrm{C}$ e mantida por $15 \mathrm{~min}$. As demais condições do método de análise foram: volume de injeção de 1,0 $\mu \mathrm{L}$ (sem divisão de fluxo), fluxo do gás de arraste (He, pureza 99,9999\%) igual a 1,0 mL min ${ }^{-1}$, 
ionização por impacto eletrônico de $70 \mathrm{eV}$, temperatura da fonte de ionização de $230^{\circ} \mathrm{C}$, do quadrupolo de $150^{\circ} \mathrm{C}$, da linha de transferência de $280^{\circ} \mathrm{C}$ e do injetor de $250^{\circ} \mathrm{C}$. O método do padrão interno foi utilizado para a quantificação em modo monitoramento de íon selecionado (SIM), sendo o íon principal utilizado para a quantificação e os íons secundários para a identificação (Tabela 3). Para confirmação da identidade dos pesticidas detectados, foi considerado um máximo de $20 \%$ de diferença entre a abundância relativa esperada dos íons secundários em relação ao principal.

Tabela 3. Pesticidas determinados, íons correspondentes monitorados e limites de detecção e quantificação dos métodos que emprega CG/EM-SIM.

\begin{tabular}{|c|c|c|c|c|c|c|c|}
\hline Pesticidas & $\begin{array}{l}\mathbf{T r}^{2} \\
(\mathbf{m i n})\end{array}$ & $\begin{array}{c}\mathbf{L D}^{\mathbf{1}} \\
\left(\mu \mathrm{g} \mathrm{kg}^{-1}\right)\end{array}$ & $\begin{array}{c}\mathbf{L Q}^{1} \\
\left(\mu \mathrm{g} \mathbf{k g}^{-1}\right)\end{array}$ & Recuperação $^{1}$ & $\begin{array}{c}\text { Íon } \\
\text { Principal }\end{array}$ & $\begin{array}{c}\text { Secundário } \\
1\end{array}$ & $\begin{array}{c}\text { Secundário } \\
2\end{array}$ \\
\hline Atrazina & 12,8 & 1,0 & 7,0 & 92 & 200,1 & 202,1 & 215 \\
\hline Cipermetrina & 29,4 & 2,5 & 6,0 & 109 & 181,1 & 163,0 & 165,0 \\
\hline$\lambda$-cialotrina & 27,6 & 1,0 & 5,0 & 86 & 181,0 & 197,0 & 208,0 \\
\hline Clorpirifós & 21,4 & 1,0 & 6,0 & 85 & 198,9 & 196,9 & 313,9 \\
\hline$\alpha$-endossulfam & 24,0 & 1,0 & 5,0 & 95 & 240,9 & 238,9 & 242,9 \\
\hline$\beta$-endossulfam & 25,2 & 5,0 & 6,0 & 103 & 236,8 & 238,8 & 195,0 \\
\hline $\begin{array}{l}\text { Endossulfam } \\
\text { sulfato }\end{array}$ & 25,9 & 2,5 & 30,0 & 95 & 271,8 & 273,8 & 236,9 \\
\hline Malationa & 20,7 & 2,0 & 31,0 & 76 & 125,0 & 127,0 & 173,1 \\
\hline Metolacloro & 20,9 & 1,0 & 7,0 & 89 & 162,1 & 238,1 & 240,1 \\
\hline Metribuzina & 16,5 & 2,5 & 5,0 & 77 & 198,0 & 199,0 & 182,0 \\
\hline $\begin{array}{l}\text { Parationa } \\
\text { Metílica }\end{array}$ & 17,0 & 2,5 & 29,0 & 78 & 109,0 & 125,0 & 263,0 \\
\hline Permetrina & 28,3 & 1,0 & 7,0 & 98 & 163,0 & 183,0 & 165,0 \\
\hline Trifuralina & 11,3 & 1,0 & 6,0 & 88 & 264,0 & 290,0 & 306,0 \\
\hline $\begin{array}{l}\text { Fenantreno D- } \\
10^{3}\end{array}$ & 13,5 & & & & 184,1 & 188,1 & 189,1 \\
\hline
\end{tabular}

Fonte: ${ }^{1}$ Miranda $(2008) .{ }^{2} \mathrm{Tr}=$ tempo de retenção; ${ }^{3}$ Padrão interno.

\section{RESULTADOS E DISCUSSÃO}

A partir dos dados de utilização de pesticidas nos municípios que compõem a bacia hidrográfica do rio Cuiabá, identificou-se que os mais utilizados foram acefato, atrazina, carbofurano, cardosulfano, clomazona, clorpirifós, diurom, endossulfam, glifosato, metomil, parationa metílica, permetrina e tebuconazol. Dentre estes, foram selecionados para determinação os pesticidas relacionados na Tabela 4, cujo potencial de transporte por 
escoamento superficial, dissolvidas em água ou associadas ao sedimento foi avaliado utilizando os critérios publicados por Goss (1992).

Tabela 4. Potencial de transporte superficial das moléculas estudadas conforme critérios reportados por Goss (1992).

\begin{tabular}{|c|c|}
\hline Alto potencial de transporte dissolvido em água & Pesticidas \\
\hline $\begin{array}{l}\mathrm{t}_{1 / 2} \text { no solo }>35 \text { dias } ; \mathrm{K}_{\mathrm{oc}}<100000 ; \mathrm{S}_{\mathrm{w}} \geq 1 \mathrm{mg} \mathrm{L}^{-1} \\
\text { ouK }_{\mathrm{oc}} \leq 700 \text { e } 10 \leq \mathrm{S}_{\mathrm{w}} \leq 100 \mathrm{mg} \mathrm{L}^{-1}\end{array}$ & $\begin{array}{l}\text { atrazina } \\
\text { clorpirifós } \\
\text { metolacloro } \\
\text { parationa metílica }\end{array}$ \\
\hline Baixo potencial de transporte dissolvido em água & Pesticidas \\
\hline $\begin{array}{l}\mathrm{K}_{\mathrm{oc}} \geq 100000 \text { ou } \mathrm{t}_{1 / 2} \text { no solo } \leq 1 \text { dia ou } \\
\mathrm{K}_{\mathrm{oc}} \leq 100 ; \mathrm{t}_{1 / 2} \text { no solo }<35 \text { dias; } \mathrm{S}_{\mathrm{w}}<0,5 \mathrm{mg} \mathrm{L}^{-1}\end{array}$ & $\begin{array}{l}\lambda \text {-cialotrina } \\
\text { malationa }\end{array}$ \\
\hline Alto potencial de transporte associado ao sedimento & Pesticidas \\
\hline $\begin{array}{l}\mathrm{t}_{1 / 2} \text { no solo } \geq 40 \text { dias; } \mathrm{K}_{\mathrm{oc}}=1000 \text { ou } \\
\mathrm{t}_{1 / 2} \text { no solo } \geq 40 \text { dias; } \mathrm{K}_{\mathrm{oc}} \geq 500 ; \mathrm{S}_{\mathrm{w}}=0,5 \mathrm{mg} \mathrm{L}^{-1}\end{array}$ & $\begin{array}{l}\text { cipermetrina } \\
\text { clorpirifós } \\
\text { endossulfam } \\
\lambda \text {-cialotrina } \\
\end{array}$ \\
\hline Baixo potencial de transporte associado ao sedimento & Pesticidas \\
\hline $\begin{array}{l}\mathrm{t}_{1 / 2} \text { no solo }<1 \text { dia ou } \leq 40 \text { dias; } \mathrm{K}_{\mathrm{oc}} \leq 500 ; \mathrm{S}_{\mathrm{w}} \geq 0,5 \mathrm{mg} \mathrm{L}^{-1} \\
\text { ou } \mathrm{t}_{1 / 2} \text { no solo } \leq 2 \text { dias ou } \mathrm{t}_{1 / 2} \text { no solo } \leq 4 \text { dias; } \mathrm{K}_{\mathrm{oc}} \leq 900 ; \mathrm{S}_{\mathrm{w}} \geq 0,5 \mathrm{mg} \mathrm{L}^{-1} \\
\text { ou } \mathrm{t}_{1 / 2} \text { no solo } \leq 40 \text { dias; } \mathrm{K}_{\mathrm{oc}} \leq 900 ; \mathrm{S}_{\mathrm{w}} \geq 2,0 \mathrm{mg} \mathrm{L}^{-1}\end{array}$ & $\begin{array}{l}\text { metribuzim } \\
\text { parationa metílica }\end{array}$ \\
\hline
\end{tabular}

Como já visto na Tabela 1, a área total plantada com culturas agrícolas na bacia aumentou em $32,4 \%$ nos últimos quatro anos, fator este que demanda um aumento também na quantidade de pesticidas aplicados nos municípios formadores da bacia. Embora novos princípios ativos possam ter surgido desde 2009 e dados atualizados sobre o uso de pesticidas não estejam disponíveis, verificou-se que os tipos de culturas de maior predominância não variaram e, dessa forma, a grande maioria dos princípios ativos utilizados possivelmente continuam sendo os mesmos. Algumas culturas agrícolas merecem atenção, não pela quantidade de pesticidas aplicados por área cultivada, e sim por essas culturas ocuparem extensas áreas nos municípios da bacia, como é o caso da soja, do milho e do algodão (Instituto Brasileiro de Geografia e Estatística, 2013).

Durante os 12 meses de monitoramento (agosto de 2011 a julho de 2012), verificou-se a presença de resíduos de pesticidas em apenas algumas amostras coletadas nos meses de agosto e setembro do ano de 2011 e nos meses de janeiro, fevereiro, abril e julho de 2012, sendo detectadas concentrações variando de 5,7 a 79,3 $\mathrm{g} \mathrm{kg}^{-1}$ (Tabela 5). Os pesticidas detectados são usados com frequência na agricultura e sua presença no sedimento deve-se provavelmente ao seu transporte adsorvido ao material particulado através do escoamento superficial.

Apresentaram contaminação amostras coletadas no ponto CBA 01 localizado no curso médio alto no município de Rosário Oeste, mais próximo da região de nascente do Rio Cuiabá, nos pontos situados em área de Planalto no Rio Tenente Amaral, afluente do rio São Lourenço em Jaciara (SL 01), bem como no encontro dos rios Vermelho e São Lourenço (SL 03); além de amostras coletadas em área de planície, em pontos no rio Cuiabá no Pantanal em Porto Cercado (CBA 03) e nos pontos correspondentes aos corixos Antônio Alves (CBA 04) e do Moquem (CBA 05). 
Dos pesticidas detectados, quatro deles ( $\alpha$-endossulfam, endossulfam sulfato, $\lambda$-cialotrina e clorpirifós), de acordo com a classificação de Goss (1992), apresentam alto potencial de transporte associado ao sedimento destacando ainda o clorpirifós, que pode ser transportado também dissolvido em água. Isso indica que esses compostos atingiram os corpos d'águas através do escoamento superficial estando fortemente ligados ou sorvidos nas moléculas do solo. Já o metolacloro e a malationa apresentam maior possibilidade de ter atingido os recursos hídricos superficiais dissolvidos em água no processo de escoamento superficial e embora essas moléculas não tenham sido detectados no período de chuva sua presença pode estar associada a eventos de chuva anteriores, uma vez que a presença no sedimento pode não refletir uma contaminação atual (Tabela 4).

Tabela 5. Concentrações de pesticidas detectadas em sedimento de fundo ( $\mu \mathrm{g} \mathrm{kg}^{-1}$ de peso seco), por ponto de coleta.

\begin{tabular}{l|ccc|cc|cc|c|c|c}
\hline \multirow{2}{*}{ Pesticidas } & \multicolumn{3}{|c|}{$\begin{array}{c}\text { Ago/11 } \\
\text { (seca) }\end{array}$} & \multicolumn{2}{c|}{$\begin{array}{c}\text { Set/11 } \\
\text { (seca) }\end{array}$} & \multicolumn{2}{c|}{$\begin{array}{c}\text { Jan/12 } \\
\text { (chuvoso) }\end{array}$} & $\begin{array}{c}\text { Fev/12 } \\
\text { (chuvoso) }\end{array}$ & $\begin{array}{c}\text { Abr/12 } \\
\text { (chuvoso) }\end{array}$ & $\begin{array}{c}\text { Jul/12 } \\
\text { (seca) }\end{array}$ \\
\cline { 2 - 10 } & CBA 01 & SL 03 & CBA 03 & SL 01 & SL 03 & CBA & SL 01 & CBA 05 & CBA 04 & CBA 01 \\
\hline Metolacloro & -2 & 21,2 & 19,1 & - & - & - & - & - & - & - \\
Permetrina & 44,5 & - & - & - & - & - & - & - & - & - \\
$\lambda$-cialotrina & 33,8 & - & 60,0 & 19,7 & 31,0 & - & - & - & - & - \\
$\alpha$-endossulfam & - & - & - & - & - & - & 13,6 & - & - & - \\
Endo. Sulfato & - & - & - & - & - & 5,7 & 25,9 & 79,3 & - & - \\
Clorpirifós & - & - & - & - & - & - & - & - & - & 8,5 \\
Malationa & - & - & - & - & - & - & - & - & 9,2 & - \\
\hline
\end{tabular}

Nota: ${ }^{1}$ período de seca e chuvoso característico do mês de coleta indicado entre parêntesis; ${ }^{2}-<$ LD do método; ${ }^{3}$ endossulfam sulfato (principal metabólito do endossulfam).

Embora dados atualizados de pesticidas utilizados na área de estudo não puderam ser disponibilizados, usando os dados de uso de pesticidas na bacia dos anos de 2008 e 2009, observou-se que dentre os pesticidas detectados em sedimento de fundo, o clorpirifós e endossulfam vinham sendo aplicados nos municípios onde foram detectados, ressaltando que ambas as moléculas apresentam persistência considerável, com tempos de meia-vida no solo iguais a 50 dias.

Desde a década de 70, a expansão da pecuária e da agricultura em áreas do Planalto tem aumentado o desmatamento e a erosão, e vários rios da região, como o Taquari e o São Lourenço, apresentam elevada capacidade de transporte de sedimentos. Isto tem aumentado a deposição de sedimentos no Pantanal e o consequente assoreamento dos rios localizados nas regiões de menor altitude (Agência Nacional de Águas, 2013). Os resultados obtidos no presente estudo indicam que pesticidas utilizados na bacia do Rio Cuiabá e em seus afluentes podem atingir o Pantanal (presença de endossulfam sulfato, clorpirifós, malationa e $\lambda$ cialotrina em pontos de coleta na planície), sendo transportados adsorvidos ao material particulado. Uma vez que as configurações geomorfológica e climatológica dentro da bacia fazem com que o escoamento proveniente do planalto seja direcionado diretamente para o Pantanal, as ações produzidas na parte superior da bacia (planalto) podem ocasionar impactos diretos sobre o Pantanal e áreas à jusante. Entretanto, devido à sua ocorrência eventual e com 
baixa frequência ao longo da bacia, não há indicação de um elevado risco de acumulação na planície.

Não foi possível verificar influência da época de coleta nos resultados. Tal fato deve-se provavelmente à característica difusa da contaminação por pesticidas e à dinâmica de sedimentação que varia durante as estações. Soma-se a isto a eventual degradação das moléculas tanto no sedimento como na coluna d'água. Não se pode deixar de considerar também que as concentrações de pesticidas encontradas no ambiente estão em geral muito próximas dos limites de detecção dos métodos analíticos e caso ocorra uma pequena diluição as concentrações podem atingir valores não detectáveis.

Em estudo desenvolvido por Laabs et al. (2002) na região nordeste do Pantanal, no qual foram coletadas amostras de sedimento de fundo nos rios São Lourenço e Cuiabá e na Baía de Siá Mariana na planície pantaneira, foram detectados ametrina, p,p'DDT, p,p'DDE, desetilatrazina, $\beta$-endossulfam, sulfato de endossulfam e simazina em concentrações variando de 0,4 a $4,5 \mu \mathrm{g} \mathrm{kg}^{-1}$, valores estes inferiores aos detectados no presente estudo. Aqueles autores coletaram amostras de novembro de 1999 a março de 2000, ou seja, somente no período chuvoso, época em que, apesar dos processos de transporte superficial serem intensificados, há também maior vazão nos rios e portanto menos deposição. Por outro lado, na área de planície os autores encontraram somente os organoclorados, mais persistentes, sendo os demais pesticidas detectados somente no planalto. No presente estudo, os pesticidas foram detectados com mais frequência nos pontos localizados no planalto, apesar de terem sido encontrados também nas amostras coletadas na planície.

Cunha (2003) avaliou o nível de contaminação de 37 pesticidas no sedimento de rio, coletados nos principais rios às bordas do Pantanal. A amostragem foi feita em duas épocas, novembro de 2001 e fevereiro de 2002, que corresponde ao início das chuvas e final das chuvas respectivamente. Este autor detectou alacloro, ametrina, clorpirifós, p,p'DDE, p,p'DDT, endossulfam sulfato, beta endossulfam, metolacloro, metoxicloro, metribuzim, simazina, terbutilazina, trifluralina. Dos princípios ativos detectados por Cunha (2003), da mesma forma, o metolacloro, o endossulfam sulfato e o clorpirifós foram também detectados em amostras de sedimento de fundo de rio avaliadas no presente estudo.

Miranda et al. (2008) verificaram a contaminação por resíduos de pesticidas nos sedimentos de fundo de 17 rios formadores do Pantanal, dentre eles, o Cuiabá, o São Lourenço e o Vermelho, que também foram avaliados no presente trabalho. Os compostos identificados em amostras de sedimento incluíram $\lambda$-cialotrina $\left(1,0-5,0 \mu \mathrm{g} \mathrm{kg}^{-1}\right), \mathrm{p}$,p'DDT $(3,6$ $\left.\mu \mathrm{g} \mathrm{kg}{ }^{-1}\right)$, deltametrina $\left(20,0 \mu \mathrm{g} \mathrm{kg}^{-1}\right)$ e permetrina $\left(1,0-7,0 \mu \mathrm{g} \mathrm{kg}^{-1}\right)$. Os princípios ativos $\lambda$ cialotrina e permetrina também foram avaliados no presente estudo, entretanto, somente a $\lambda$ cialotrina foi identificada em amostras de sedimento de fundo de rio apresentando concentrações superiores àquelas verificadas por Miranda.

Inseticidas piretróides têm sido detectados em sedimentos de fundo de rio em diversos países do mundo (Delgado-Moreno et al., 2011; Ensminger et al., 2013; Li et al., 2013; Toan et al., 2013) com destaque para a cipermetrina, deltametrina, bifentrina, $\lambda$-cialotrina e permetrina, sendo estas duas últimas detectadas no presente trabalho. Tal fato deve-se provavelmente ao uso intensivo dessa classe de pesticidas em diversas culturas associado aos elevados coeficientes de sorção $\left(\mathrm{K}_{\mathrm{oc}}\right.$ entre 100.000 e $\left.1.000 .000 \mathrm{~mL} \mathrm{~g}^{-1}\right)$ destas moléculas ao solo que contribui para seu carreamento para os cursos d'água associados ao particulado.

Outros pesticidas detectados com frequência em sedimento por vários autores em diferentes regiões do mundo são o endossulfam (isômeros alfa e beta e seu principal metabólito sulfato de endossulfam) e o clorpirifós (Masiá et al., 2013; Miglioranza et al., 2013; Li et al., 2013; Silva et al., 2008). Em estudo realizado no Pantanal por Laabs et al. (2007) no qual foi avaliada a dissipação de nove pesticidas usando mesocosmos, os autores observaram que o endossulfam beta seguido do metolacloro, atrazina, simazina e clorpirifós 
foram os mais persistentes nestes ambientes sendo que o endossulfam e o clorpirifós tenderam a se acumular no sedimento, o que explica a detecção dessas moléculas nas amostras analisadas.

\section{CONCLUSÃO}

De um total de 216 amostras, apenas 10 apresentaram contaminação com pelo menos um princípio ativo, em concentrações variando de 5,7 a 79,3 $\mu \mathrm{g} \mathrm{kg}^{-1}$, sendo detectados clorpirifós, endossulfam ( $\alpha$ e sulfato), $\lambda$-cialotrina, malationa, metolacloro e permetrina. Embora a frequência de detecção tenha sido baixa, verificou-se a presença de resíduos de pesticidas em amostras correspondentes ao Pantanal. Conclui-se assim que há potencial para transporte de pesticidas para dentro do ambiente aquático na bacia do Rio Cuiabá mesmo que em concentrações e frequência de detecção baixas.

\section{REFERÊNCIAS}

AGÊNCIA NACIONAL DE ÁGUAS - ANA (Brasil). Projeto de implementação de práticas de gerenciamento integrado de bacia hidrográfica para o Pantanal e Alto Paraguai. ANA/GEF/PNUMA/OEA: Subprojeto: avaliação dos mecanismos financeiros para gerenciamento sustentável da bacia piloto do Rio Cuiabá. Brasília, DF, 2003.

AGÊNCIA NACIONAL DE ÁGUAS - ANA (Brasil). Região hidrográfica do Paraguai. Brasília, DF, 2013. Disponível em: <http://www2.ana.gov.br/Paginas/portais /bacias/paraguai.aspx>. Acesso em: $10 \mathrm{dez} .2013$.

AGÊNCIA NACIONAL DE VIGILÂNCIA SANITÁRIA - ANVISA (Brasil). Seminário volta a discutir mercado de agrotóxicos em 2012. Brasília, DF, 2012. Disponível em: $<$ http://portal.anvisa.gov.br/wps/content/anvisa + portal/anvisa/sala + de + imprensa/menu+ + noticias + anos/2012+noticias/seminario + volta $+\mathrm{a}+$ discutir + mercado + de + agrotoxicos $+\mathrm{e}$ m+2012>. Acesso em: 12 dez. 2013.

BAEK, S.; CHOI, S.; CHANG, Y. Three-year atmospheric monitoring of organochlorine pesticides and polychlorinated biphenyls in polar regions and the south pacific. Environmental Science and Technology, v. 45, n. 10, p. 4475-4482, 2011. http://dx.doi.org/10.1021/es1042996

BRADSHAW C.; TJENSVOLL, I.; SKÖLD, M.; ALLAN, I. J.; MOLVAER, J.; MAGNUSSON, J.; NAES, K.; NILSSON, H. C. Bottom trawling resuspends sediment and releases bioavailable contaminants in a polluted fjord. Environmental Pollution, v. 170, p. 232-241, 2012. http://dx.doi.org/10.1016/j.envpol.2012.06.019

CABRERA, C. L; COSTA, F. B; PRIMEL, E. G. Estimativa de risco de contaminação das águas por pesticidas na região sul do estado do RS. Química Nova, v. 31, n. 8, p.19821986, 2008. http://dx.doi.org/10.1590/S0100-40422008000800012

CUNHA, M. L. Determinação de resíduos de pesticidas em sedimentos dos principais rios do Pantanal Mato-grossense por CG/EM. 2003. 91f. Dissertação (Mestrado em Saúde e Ambiente) - Instituto de Saúde Coletiva, Universidade Federal de Mato Grosso, Cuiabá, 2003. 
DELGADO-MORENO, L.; LIN, K.; VEIGA-NASCIMENTO, R.; GAN, J. Occurrence and toxicity of three classes of insecticides in water and sediment in two Southern California Coastal Watersheds. Journal of Agricultural and Food Chemistry, v. 59, p. 94489456, 2011. http://dx.doi.org/10.1021/jf202049s

DORES, E. F. G. C.; DE-LAMONICA-FREIRE, E. M. Contaminação do ambiente aquático por pesticidas: estudo de caso: águas usadas para consumo humano em Primavera do Leste, Mato Grosso - Análise preliminar. Química Nova, v. 24, n. 1, p. 27-36, 2001. http://dx.doi.org/10.1590/S0100-40422001000100007

ENSMINGER, M. P.; BUDD, R.; KELLEY, K. C.; GOH, K. S. Pesticide occurrence and aquatic benchmark exceedances in urban surface waters and sediments in three urban areas of California, USA, 2008-2011. Environmental Monitoring and Assessment, v. 185, p. 3697-3710, 2013. http://dx.doi.org/10.1007/s10661-012-2821-8

GEBREMARIAM, S. Y; BEUTEL, M. W.; YONGE, D.R.; FLURY, M.; HARSH, J. B. Adsorption and desorption of chlorpyrifos to soils and sediments. Reviews of Environmental Contamination and Toxicology, v. 215, p. 123-75, 2012. http://dx.doi.org/10.1007/978-1-4614-1463-6_3

GOSS, D. W. Screening procedure for soils and pesticides potential water quality impacts. Weed Technology, v. 6, p. 701-708, 1992. http://www.jstor.org/stable/3987238

GRANBERG , M. E.; GUNNARSSON , J. S.; HEDMAN , J. E.; ROSENBERG , R.; JONSSON , P. Bioturbation-driven release of organic contaminants from Baltic Sea sediments mediated by the invading polychaete Marenzelleria neglecta. Environmental Science and Technology, v. 42, p. 1058-1065, 2008. http://dx.doi.org/10.1021/es071607j

INSTITUTO BRASILEIRO DE GEOGRAFIA E ESTATÍSTICA - IBGE. Relatório de área plantada por município no Mato Grosso, 2008-2012. Rio de Janeiro, 2013.

JAFFÉ, R. Fate of hydrophobic organic pollutants in the aquatic environment: a review. Environmental Pollutions, v. 69, p. 237-257, 1991. http://dx.doi.org/10.1016/02697491(91)90147-O

LAABS, V.; AMElUnG, W.; PINTO, A.; WANTZEN, M.; SILVA, C. J.; ZECH, W. Pesticides in surface water, sediment, and rainfall of the Northeastern Pantanal Basin, Brazil. Journal of Environmental Quality, v. 31, p. 1636-1648, 2002. http://dx.doi.org/10.2134/jeq 2002.1636

LAABS, W.; WEHRHAN, A.; PINTO, A. A.; DORES, E. F. G. C.; AMELUNG, W. Pesticide fate in tropical wetlands of Brazil: An aquatic microcosm study under semifield conditions. Chemosphere, v. 67, p. 975-989, 2007. http://dx.doi.org/10.1016/j. chemosphere.2006.10.067

LI, H.; SUN, B.; LYDY, M. J.; YOU, J. Sediment-associated pesticides in an urban stream in Guangzhou, China: implication of a shift in pesticide use patterns. Environmental Toxicology and Chemistry, v. 32, n. 5, p. 1040-1047, 2013. http://dx.doi.org/10.1002/etc.2147

MALIK, A.; SINGH, V. D. K.; SINGH, K. P. Occurrence and distribution of persistent trace organics in rainwater in an urban region (India). Bulletin of Environmental

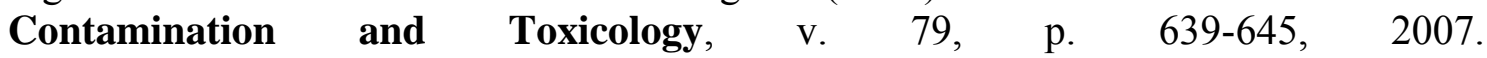
http://dx.doi.org/10.1007/s00128-007-9290-8 
MASIÁ, A.; CAMPO, J.; VÁZQUEZ-ROIG, P.; BLASCO, C.; PICÓ, Y. Screening of currently used pesticides in water, sediments and biota of the Guadalquivir River Basin (Spain). Journal of Hazardous Materials, v. 263P, p. 95-104, 2013. http://dx.doi.org/10.1016/j.jhazmat.2013.09.035

MATO GROSSO. Secretaria de Estado do Meio Ambiente. Superintendência de monitoramento de indicadores ambientais. Relatório de Monitoramento de Qualidade das Águas da Sub-bacia do Rio Cuiabá, MT - 2005. Cuiabá: SEMA/MT; SMIA, 2006.

MATO GROSSO. Secretaria de Estado do Meio Ambiente. Recuperação de áreas degradadas: uma proposta para o cerrado da Bacia Hidrográfica do Rio São Lourenço - Mato Grosso. Brasília, 2008. Disponível em: $<$ http://lcf.esalq.usp.br/prof/pedro/lib/exe/fetch.php?media= ensino:graduacao:manual_2008_recuperacao_bacia_do_sao_lourenco.pdf.> Acesso em: 12 Dez. 2013.

MATO GROSSO. Secretaria de Estado do Meio Ambiente. Superintendência de Monitoramento de Indicadores Ambientais. Relatório de monitoramento da qualidade da água da região hidrográfica do Paraguai - 2007 a 2009. Cuiabá: SEMA/MT; SMIA, 2010.

MIGLIORANZA, K. S. B.; GONZALEZ, M.; ONDARZA, P. M.; SHIMABUKURO, V. M.; ISLA, F. I.; FILLMANN, G. et al. Assessment of Argentinean Patagonia pollution: PBDEs, OCPs and PCBs in different matrices from the Río Negro basin. Science of the Total Environment, v. 452-453, p. 275-285, 2013. http://dx.doi.org/10.1016/j. scitotenv.2013.02.055

MIRANDA, K. A.; CUNHA, M. L. F.; DORES, E. F. G. C.; CALHEIROS, D. F. Pesticide residues in river sediments from the Pantanal Wetland, Brazil. Journal of Environmental Science and Health B, v. 43, p. 717-722, 2008. http://dx.doi.org/10.1080/03601230802388843

NOGUEIRA, E. N.; DORES, E. F. G. C.; PINTO, A. A.; AMORIM, R. S. S.; RIBEIRO, M. L.; LOURENCETTI, C. Currently used pesticides in water matrices in central-western Brazil. Journal of Brazilian Chemical Society, v. 23, p. 1476-1487, 2012. http://dx.doi.org/10.1590/S0103-50532012005000008

RIBEIRO, A. C. A.; DORES, E. F. G. C.; AMORIM, R. S. S.; LOURENCETTI, C. Resíduos de pesticidas em águas superficiais de área de nascente do rio São Lourenço-MT: Validação de método por extração em fase sólida e cromatografia líquida. Química Nova, p. 284-290, 2013. http://dx.doi.org/10.1590/S0100-40422013000200015

ROCHA, J. C.; ROSA, A. H.; CARDOSO A. A. Introdução à química ambiental. 2. ed. São Paulo: Artmed 2009. p. 29.

SILVA, D. M. L.; CAMARGO, P. B.; MARTINELLI, L. A.; LANÇAS, F. M.; PINTO, J. S. S.; AVELAR, W. E. P. Organochlorine pesticides in Piracicaba river basin (São Paulo/Brazil): a survey of sediment, bivalve and fish. Química Nova, v. 31, n. 2, p. 214-219, 2008. http://dx.doi.org/10.1590/S0100-40422008000200005

SPADOTTO, C. A.; GOMES, M. A. F. Agrotóxicos no Brasil. Brasília, DF: EMBRAPA,

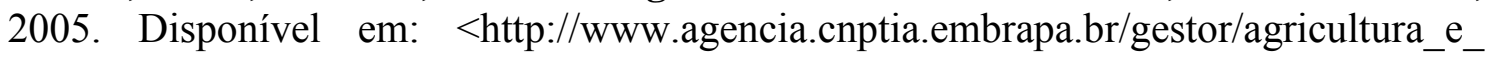
meio_ambiente/arvore/CONTAG01_40_210200792814.html>. Acesso em: 12 dez. 2013 . 
TOAN, P. V.; SEBESVARI, Z.; BLÄSING, M.; ROSENDAHL, I.; RENAUD, F. G. Pesticide management and their residues in sediments and surface and drinking water in the Mekong Delta, Vietnam. Science of the Total Environment, v. 452-453, p. 28-39, 2013. http://dx.doi.org/10.1016/j.scitotenv.2013.02.026 


Ambiente \& Água - An Interdisciplinary Journal of Applied Science
ISSN 1980-993X - doi:10.4136/1980-993X
www.ambi-agua.net
E-mail: ambi-agua@agro.unitau.br

\title{
Acúmulo de nutrientes por forrageiras cultivadas em sistema de escoamento superficial para tratamento de esgoto doméstico
}

\author{
doi: 10.4136/ambi-agua.1210 \\ Received: 06 Oct 2013; Accepted: 23 Dec. 2013
}

\begin{abstract}
Aline Azevedo Nazário ${ }^{1 *}$; Giovanni de Oliveira Garcia $^{2}$; Edvaldo Fialho dos Reis $^{2}$; Eduardo de Sá Mendonça ${ }^{3}$; José Guilherme Bergamim Melline ${ }^{3}$

${ }^{1}$ Universidade de Campinas (UNICAMP) - Faculdade de Engenharia Agrícola - Campinas, SP, Brasil Departamento de Água e Solo - Programa de Pós-graduação em Produção Vegetal (CCA-UFES)

${ }^{2,3}$ Universidade Federal do Espírito Santo (UFES) - Centro de Ciências Agrárias - Alegre, ES, Brasil

${ }^{2}$ Departamento de Engenharia Rural

${ }^{3}$ Departamento de Produção Vegetal

*Autor correspondente: e-mail: aline.a.n@hotmail.com, giovanni.garcia@ufes.br, edreis@cca.ufes.br, eduardo.mendonca@ufes.br,jgmellere@hotmail.com
\end{abstract}

\section{RESUMO}

Atualmente, observa-se deterioração da qualidade das águas, a qual está vinculada ao crescimento populacional e as diversas atividades de produção agroindustriais, neste contexto o trabalho teve como objetivo avaliar o desempenho de três espécies forrageiras utilizadas no tratamento de esgoto doméstico (ED) por meio da disposição no solo aplicando a técnica do escoamento superficial. O experimento foi conduzido no Centro de Ciências Agrárias da Universidade Federal do Espírito Santo usando delineamento experimental inteiramente casualizado com três repetições no esquema de parcela sub-subdividida $3 \times 5 \times 2$. As parcelas, em três níveis, foram compostas pelas espécies Brachiaria brizantha cv. Marandu, Cynodon sp. cv Tifton 85 e Paspalum atratum cv. Pojuca, nas subparcelas, em 5 níveis as taxas de aplicação de efluentes com 7,91; 15,$81 ; 23,72 ; 31,63$ e $39,54 \mathrm{~kg} \mathrm{ha}^{-1} \mathrm{dia}^{1}$ de DBO e foram realizados dois cortes no material vegetal em ciclos de 28 dias após o início da aplicação dos tratamentos. Os resultados mostraram que o acúmulo de nutrientes pelas forrageiras foi superior aos relatados em literatura para o capim Marandu, Tifton 85 e Pojuca. Esses resultados reforçam o potencial desses capins para o tratamento de águas residuárias, especialmente efluente de ED.

Palavras-chave: efluentes, disposição no solo, macronutrientes.

\section{Accumulation of nutrients by forage grown in domestic sewage treatment runoff system}

\begin{abstract}
It is evident today that water quality is declining. This deterioration is mainly due to population growth and several aspects of agro-industrial production. This work therefore aimed to evaluate the performance of three forage species which are used for the treatment of domestic sewage (DS) applied to the soil via the superficial runoff technique. This experiment
\end{abstract}


was conducted at the Agrarian Sciences Center of the Federal University of Espírito Santo, Brazil using a completely randomized design experimental delineation, with three replications in a split plot technique $3 \times 5 \times 2$. The plots were composed of Brachiaria brizantha cv. Marandu, Cynodon sp. cv Tifton 85 and Paspalum atratum cv. Pojuca, with five levels of effluent application rates in the subplots: 7.91, 15.81, 23.72, 31.63 and $39.54 \mathrm{~kg} \mathrm{ha}^{-1}$ day $^{1}$ BOD. Two cuts of the plant material were done at 28-day intervals after the treatment application. The results showed that nutrient accumulation by the forage was higher than that reported in literature for Marandu grass, Tifton 85 and Pojuca. These results highlight the potential of these grasses on wastewater treatment, especially DS effluent.

Keywords: effluents, disposal in soil, macronutrients.

\section{INTRODUÇÃO}

A deterioração da qualidade das águas está vinculada ao crescimento populacional das últimas décadas, notadamente nos meios urbanos, juntamente com o incremento de produção nas mais diversas atividades agroindustriais, consequentemente, houve o incremento na geração de grande quantidade de resíduos sólidos, líquidos e gasosos.

Como reflexo do crescimento populacional e da produção de bens de consumo a geração de grande quantidade de resíduos sólidos, líquidos e gasosos toma proporções alarmantes. Em particular, o lançamento de resíduos líquidos, também chamados de água residuária, nos corpos d'água naturais conduz ao estabelecimento de processos poluidores prejudiciais aos sistemas aquáticos que comprometem os usos ao qual aquele manancial estava destinado (Melo e Marques, 2000).

Estudos recentes indicam que a disposição de águas residuárias no solo pode aumentar a produtividade das culturas, melhorar a qualidade dos produtos colhidos, promover melhorias em algumas propriedades físicas do solo, além de possibilitar redução na poluição ambiental (Ribeiro et al., 2009).

O solo e plantas atuam como "filtro vivo" absorvendo e retendo poluentes e organismos patogênicos presentes em resíduos e águas residuárias. Esta disposição completa a sequência de tratamentos de águas residuárias para a redução dos níveis de microrganismos e de vários componentes orgânicos e inorgânicos para níveis aceitáveis (Feigin et al., 1991).

A irrigação e a fertirrigação em pastagem são técnicas cujas aplicações vêm crescendo no Brasil, possibilitando obter forrageiras de melhor valor nutricional, além de favorecer o manejo racional do sistema de produção animal (Drumond et al., 2006).

Os esgotos aplicados no solo conduzem à recarga do lençol subterrâneo e, ou, à evapotranspiração, além de suprirem as necessidades das plantas, tanto em nutrientes, quanto na demanda hídrica, sendo esta dependente da quantidade nutriente para determinação da lâmina aplicada. A capacidade do solo em conduzir à assimilação de compostos orgânicos complexos depende de suas propriedades e condições climáticas. Taxa de infiltração e tipos de cobertura vegetal são fatores importantes no uso do solo como meio de degradação de resíduos orgânicos. Tal degradação requer boa aeração do solo a qual, por sua vez, é inversamente relacionada à umidade do solo. Condições de insuficiente aeração vão conduzir a uma menor capacidade de assimilação do resíduo orgânico pelo solo (Von Sperling, 1996).

Um dos métodos utilizados para disposição de efluentes no solo é o escoamento superficial que consiste na aplicação, controlada, da descarga de águas residuárias, fazendo-as escoarem, no solo, por uma rampa plantada e inclinada, até alcançar canais de coleta. À medida que o efluente percorre o terreno, grande parte evapora, uma menor parte infiltra no solo e o restante é coletado em canais, posicionados na parte inferior da rampa de tratamento (Paganini, 1997). De acordo com Bertoncini (2008), ao utilizar-se do método de escoamento superficial, a rampa deve ser cultivada com capins como a Brachiaria humidicola, Brachiaria 
arrecta, Typha latifolio e Cynodon dactylon (Tifton 85), dentre outros, pois permitem o desenvolvimento dos microrganismos decompositores da matéria orgânica em seu sistema radicular abundante, são bons controladores de erosão e produzem elevada massa verde, absorvendo grandes quantidades de nutrientes do solo.

Dessa forma, há necessidade de informações que visem adequar sistemas de tratamento de efluentes e esclarecer dúvidas que existem frequentemente, como a resposta deste método de tratamento em regiões tropicais. Neste sentido, o trabalho teve como objetivo avaliar a extração de nutrientes de diferentes forrageiras submetidas à irrigação com efluente de esgoto doméstico sobre escoamento superficial.

\section{MATERIAL E MÉTODOS}

O experimento foi realizado na área experimental do Centro de Ciências Agrárias da Universidade Federal do Espírito Santo, no município de Alegre - ES, tendo como

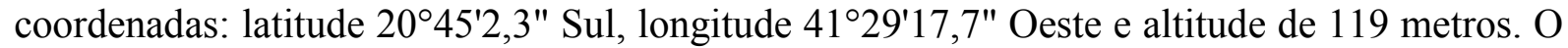
clima da região típico é quente e úmido no verão e seco no inverno, com temperatura anual média é de $23,1^{\circ} \mathrm{C}$ e precipitação média anual de $1.349 \mathrm{~mm}$.

Para montagem do experimento foi construída uma estrutura de alvenaria, contendo 45 unidades experimentais de $1,0 \times 0,2 \times 0,3 \mathrm{~m}$, impermeabilizadas com manta asfáltica e $8 \%$ de declividade. Foram utilizados dois reservatórios de 5.000 litros abastecidos com esgoto doméstico (ED) proveniente de fossas sépticas.

A caracterização química do esgoto doméstico utilizado durante o período experimental está apresentada na Tabela 1 (APHA et al., 1999). O solo de textura média (Franco Arenoso) utilizado no experimento foi coletado no perfil natural de um Latossolo Vermelho-Amarelo na área experimental do Centro de Ciências Agrárias (CCA-UFES), no qual foi seco ao ar, peneirado em malha de $4 \mathrm{~mm}$, e deposto em cada unidade experimental. Uma amostra do solo foi encaminhada ao laboratório onde se determinou os atributos químicos (Tabela 1) conforme metodologia proposta pela EMBRAPA (1997).

Tabela 1. Características químicas do esgoto doméstico e atributos químicos do solo utilizado no preenchimento das rampas cultivadas.

\begin{tabular}{|c|c|c|c|c|c|c|c|c|c|c|c|}
\hline \multicolumn{12}{|c|}{ Esgoto doméstico } \\
\hline pH & $\begin{array}{c}\text { C.E } \\
\left(\mathrm{dS} \mathrm{m}^{-1}\right)\end{array}$ & $\mathbf{N}^{*}$ & $\mathbf{P}$ & $\mathbf{K}$ & Ca & $\begin{array}{c}\mathbf{M g} \\
\left.\mathrm{g} \mathrm{L}^{-1}\right)-\end{array}$ & $\mathrm{Na}$ & $\mathbf{F e}$ & B & Mn & $\begin{array}{c}\text { RAS } \\
\left(\mathrm{cmol}_{\mathrm{c}} \mathrm{L}^{-1}\right)\end{array}$ \\
\hline 7,85 & 0,91 & 227,75 & 18,27 & 56,8 & 0,88 & 0,43 & 3,83 & 0,81 & 0,55 & 0,17 & 4,72 \\
\hline \multicolumn{12}{|c|}{ Solo } \\
\hline $\mathbf{P}$ & $\mathbf{K}$ & $\mathbf{N a}$ & $\mathbf{S}$ & $\mathbf{F e}$ & $\mathrm{Cu}$ & Mn & ISNa & SB & & $\mathbf{V}$ & $\mathbf{m}$ \\
\hline \multirow[t]{3}{*}{2,0} & 97 & 3,0 & 6,0 & 48,0 & 1,2 & 43,0 & 0,47 & 2,75 & & 55,9 & 0,0 \\
\hline & $\mathbf{C a}$ & Mg & $\mathbf{A l}$ & Al & $\mathbf{T}$ & $\mathbf{t}$ & & $\mathbf{C}$ & & М. $O$. & pH \\
\hline & 1,7 & 0,8 & 2 & 0,0 & 4,91 & 2,75 & & 6,6 & & 11,5 & 5,4 \\
\hline
\end{tabular}

*Semimicro kjeldahl; $\mathrm{CE}=$ condutividade elétrica; $\mathrm{N}=$ nitrogênio; $\mathrm{P}=$ fósforo; $\mathrm{K}=$ potássio; $\mathrm{Ca}=$ cálcio; $\mathrm{Mg}=$ magnésio; $\mathrm{Na}$ = sódio; $\mathrm{Fe}=$ ferro; $\mathrm{B}=$ boro; $\mathrm{Mn}=$ manganês; $\mathrm{RAS}=$ razão adsorção de sódio; $\mathrm{S}=$ enxofre; $\mathrm{Cu}=\mathrm{cobre}$; $\mathrm{ISNa}=$ índice de saturação de sódio; $\mathrm{SB}=$ soma de bases; $\mathrm{V}=$ saturação de bases; $\mathrm{H}+\mathrm{Al}=$ hidrogênio + alumínio; $\mathrm{Al}=$ alumínio; $\mathrm{T}=\mathrm{CTC}$ total; $\mathrm{t}=\mathrm{CTC}$ efetiva; $\mathrm{C}=$ carbono; $\mathrm{M}$. O. = matéria orgânica. 
$\mathrm{O}$ experimento foi montado no esquema de parcela sub-subdividida $3 \times 5 \times 2$, sendo nas parcelas espécies de forrageiras em três níveis, nas subparcelas taxa de aplicação do esgoto doméstico em cinco níveis e nas sub-subparcelas cortes do material vegetal em dois níveis, num delineamento inteiramente casualizado com três repetições. Os três níveis das espécies de forrageiras foram: Capim Marandu (Brachiaria brizantha cv. Marandu), Tifton 85 (Cynodon sp. cv Tifton 85) e Capim Pojuca (Paspalum atratum cv. Pojuca). Os cinco níveis das taxas de aplicação de esgoto doméstico bruto foram: 7,91; 15,82; 23,73; 31,64 e 39,55 $\mathrm{kg} \mathrm{ha}^{-1} \mathrm{dia}^{1}$ de DBO do ED. Os dois cortes no material vegetal foram em dois ciclos de 28 dias após o início da aplicação do esgoto doméstico bruto.

O plantio das mudas foi feito manualmente. Após o plantio, as mudas foram irrigadas com água provenientes da rede de abastecimento urbana por 28 dias. Transcorridos esse período foi realizado um corte de uniformidade das plantas, para iniciar os tratamentos. Depois de iniciado a aplicação com ED, esta foi à única fonte de água para as plantas, onde uma cobertura com plástico tipo polietileno foi feita para evitar contato com água da chuva, sendo cultivadas no período de verão de dezembro a março.

Os cortes foram realizados a cada 28 dias, perfazendo 2 ciclos de corte. O material vegetal foi cortado manualmente com auxílio de tesoura em todas as unidades experimentais, e acondicionado em sacos de papel e levados para estufa de circulação forçada de ar à temperatura de $55 \pm 2{ }^{\circ} \mathrm{C}$ durante $72 \mathrm{~h}$, para determinação da massa seca (Silva e Queiroz, 2002). O material seco foi triturado em moinho tipo Wiley com peneira de 30 mesh de malha, acondicionado em saco de papel, e levado ao laboratório para determinação dos teores totais de nitrogênio, fósforo, potássio, cálcio, magnésio, enxofre (EMBRAPA, 1999). O acúmulo de nutrientes foi obtido pelo produto dos teores de cada elemento pela produção total de matéria seca por hectare.

Os dados de acúmulo de nutrientes de cada espécie de gramínea, nos cortes efetuados foram analisados pelo teste $\mathrm{F}$ da análise de variância, ao nível de significância de $5 \%$, sendo os valores significativos de caráter quantitativo submetidos à análise de regressão, para determinação do desempenho das forrageiras, decorrente das taxas de aplicação do esgoto doméstico, e os valores de caráter qualitativos submetidos a um teste de média (Tukey) para determinar a diferença entre os tratamentos aplicados.

\section{RESULTADOS E DISCUSSÃO}

Na Figura 1A, nota-se o efeito linear da extração de nitrogênio com o aumento das taxas de aplicação de ED, para ambos os cortes. Para o fator corte em cada nível da taxa de aplicação, verifica-se que o primeiro corte diferiu do segundo corte em todas as taxas de aplicação de ED (Tabela 2).

No estudo do fator corte para cada nível de forrageira, o capim Tifton 85 apresentou maior acúmulo de nitrogênio no primeiro corte seguido de capim Marandu e Pojuca (Tabela 3). No segundo corte o capim Marandu não diferiu do Tifton 85 que superaram o capim Pojuca no acúmulo de nitrogênio. Por sua vez, entre os cortes, o acúmulo de nitrogênio não apresentou diferença para o capim Marandu. No entanto, o Tifton 85 e o capim Pojuca apresentaram superioridade no primeiro corte. Estes resultados se devem as características agronômicas de cada cultivar, o que explica o maior acúmulo pelo capim Tifton, que é um cultivar de elevada exigência nutricional, consequentemente de alto valor nutritivo e grande capacidade de absorver nutrientes. 

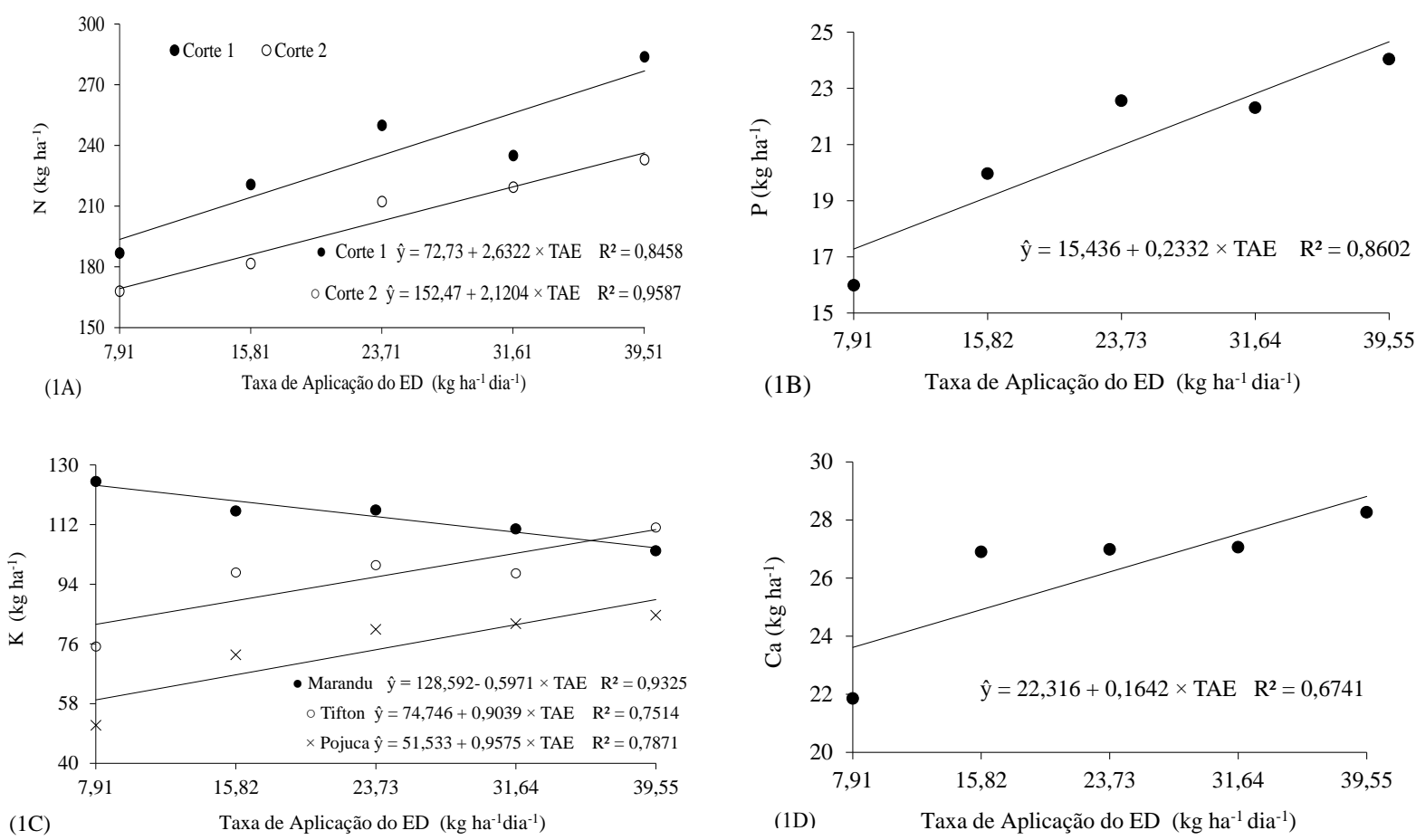

Figura 1. A) Acúmulo de Nitrogênio, B) Fosforo, C) Potássio e D) Cálcio em função da taxa de aplicação de ED para cada corte.

Tabela 2. Valores de acúmulo de nitrogênio $\left(\mathrm{kg} \mathrm{ha}^{-1}\right)$ em função das taxas de aplicação do ED e dos cortes.

\begin{tabular}{c|ccccc}
\hline \multirow{2}{*}{ Cortes } & \multicolumn{5}{|c}{ Taxa de aplicação de ED $\left(\mathbf{k g ~ h a}^{\mathbf{- 1}} \mathbf{d i a}^{\mathbf{- 1}}\right)$} \\
\cline { 2 - 6 } & 7,91 & 15,82 & 23,73 & 31,64 & 39,54 \\
\hline 1 & $186,8 \mathrm{a}$ & $220,6 \mathrm{a}$ & $249,8 \mathrm{a}$ & $234,9 \mathrm{a}$ & $283,7 \mathrm{a}$ \\
2 & $167,9 \mathrm{~b}$ & $181,6 \mathrm{~b}$ & $212,2 \mathrm{~b}$ & $179,3 \mathrm{~b}$ & $202,9 \mathrm{~b}$ \\
\hline
\end{tabular}

*Médias seguidas pela mesma letra minúscula em coluna não diferem entre si, ao nível de 5\% de probabilidade pelo teste de Tukey.

Tabela 3. Valores de acúmulo de nitrogênio $(\mathrm{N})$, fósforo $(\mathrm{P})$, cálcio $(\mathrm{Ca})$, Magnésio $(\mathrm{Mg})$ e enxofre $(\mathrm{S})$ $\left(\mathrm{kg} \mathrm{ha}^{-1}\right)$ em função das forrageiras e dos cortes.

\begin{tabular}{|c|c|c|c|c|c|c|}
\hline \multirow{3}{*}{ Forrageira } & \multicolumn{2}{|c|}{$\mathbf{N}$} & \multicolumn{2}{|c|}{$\mathbf{P}$} & \multicolumn{2}{|c|}{$\mathbf{C a}$} \\
\hline & \multicolumn{6}{|c|}{ Cortes } \\
\hline & $1^{\circ}$ & $2^{\circ}$ & $1^{\circ}$ & $2^{\circ}$ & $1^{\circ}$ & $2^{\circ}$ \\
\hline B. brizantha cv. Marandu & $228,5 \mathrm{Ab}$ & $227,6 \mathrm{Aa}$ & $24,1 \mathrm{Ba}$ & $29,9 \mathrm{Aa}$ & $24,6 \mathrm{Ab}$ & $23,4 \mathrm{Aa}$ \\
\hline Cynodon sp. cv. Tifton 85 & $282,3 \mathrm{Aa}$ & $221,8 \mathrm{Ba}$ & $19,9 \mathrm{Bb}$ & $23,5 \mathrm{Ab}$ & $25,9 \mathrm{Ab}$ & $21,6 \mathrm{Ba}$ \\
\hline P. atratum cv. Pojuca & $194,8 \mathrm{Ac}$ & $116,8 \mathrm{Bb}$ & $12,1 \mathrm{Bc}$ & $16,3 \mathrm{Ac}$ & $40,1 \mathrm{Aa}$ & $21,6 \mathrm{Ba}$ \\
\hline \multirow{3}{*}{ Forrageira } & & \multicolumn{2}{|c|}{$\mathrm{Mg}$} & \multicolumn{2}{|c|}{$\mathrm{S}$} & \\
\hline & & \multicolumn{4}{|c|}{ Cortes } & \\
\hline & & $1^{\mathrm{o}}$ & $2^{\circ}$ & $1^{\mathrm{o}}$ & $2^{o}$ & \\
\hline B. brizantha $\mathrm{cv}$. Marandu & & $29,7 \mathrm{Ab}$ & $23,8 \mathrm{Ba}$ & $19,1 \mathrm{Aa}$ & $11,2 \mathrm{Bb}$ & \\
\hline Cynodon sp. cv. Tifton 85 & & $19,3 \mathrm{Ac}$ & $14,0 \mathrm{Bb}$ & $15,4 \mathrm{Aa}$ & $18,2 \mathrm{Aa}$ & \\
\hline P. atratum cv. Pojuca & & $33,4 \mathrm{Aa}$ & $17,1 \mathrm{Bb}$ & $13,3 \mathrm{Aa}$ & $8,3 \mathrm{Ab}$ & \\
\hline
\end{tabular}

*Médias seguidas pela mesma letra minúscula em coluna, maiúscula em linha não diferem entre si, ao nível de 5\% de probabilidade pelo teste de Tukey. 
Galzerano e Morgado (2007) relataram em suas considerações finais que para o capim Tifton 85 a produção e qualidade deste aumentam à medida que se eleva a quantidade de nitrogênio aplicada, indicando que para obtenção de bons índices de produção, a adubação nitrogenada torna-se prática indispensável.

Os resultados de acúmulo de nitrogênio para o capim Marandu, média de 3,26 dag kg ${ }^{-1}$ $\left(228,08 \mathrm{~kg} \mathrm{ha}^{-1}\right)$, capim Tifton média de 3,54 dag $\mathrm{kg}^{-1}\left(252,06 \mathrm{~kg} \mathrm{ha}^{-1}\right)$ estão acima do considerado adequado para Brachiaria brizantha $\left(1,3-2,0\right.$ dag $\left.\mathrm{kg}^{-1}\right)$ e para Tifton $85(2,0-2,6$ dag $\mathrm{kg}^{-1}$ ), segundo Werner et al. (1996).

Os dados apresentados neste trabalho corroboram com os obtidos por Silva Neto et al. (2010) que verificaram, com o uso de esgoto de lavagem de frigorífico em área com capim Brachiaria, aumento nos teores de nitrogênio foliar com as maiores doses de efluente aplicado, nos dois cortes realizados durante o trabalho. Tais autores atribuíram esse resultado à disponibilização do nitrogênio pelo esgoto de frigorífico, na forma mineral assimilada pela planta.

De acordo com trabalho de Primavesi et al. (2004), os valores de extração de nitrogênio para o capim Coastcross variou de 69 a $475 \mathrm{~kg} \mathrm{ha}^{-1}$ quando se usou uréia no solo, onde os autores justificam esta variação de acordo com a produção de forragem, onde quanto maior a produção, mais elevada será a remoção de nutrientes pela forrageira. Os resultados destes autores se assemelham com os do presente trabalho, onde o maior acúmulo de nitrogênio pelas forrageiras foi exatamente no primeiro ciclo de corte que obteve maior rendimento de matéria seca.

Observa-se na Figura 1B que o aumento das taxas de aplicação de ED proporcionou efeito linear no acúmulo de fósforo atingindo valor máximo quando aplicada a taxa de ED de $37,67 \mathrm{~kg} \mathrm{ha}^{-1} \mathrm{dia}^{-1}$. Estes resultados encontram-se acima do adequado para o estado nutricional das forrageiras em estudo, onde Werner et al. (1996) apresentam faixas que variam de $0,08-0,3$ dag $\mathrm{kg}^{-1}$ dependendo da forrageira avaliada, e os valores do presente trabalho para acúmulo de fósforo nas plantas em estudo com a menor taxa de ED foi maior que $15 \mathrm{~kg}$ $\mathrm{ha}^{-1}\left(0,30 \mathrm{dag}_{\mathrm{kg}}{ }^{-1}\right)$, ou seja, a menor taxa de aplicação de ED já atenderia a demanda de fósforo das forrageiras. Porém, sintomas de toxidez não foram observados, fato que pode ser justificado pelo $\mathrm{pH}$ do solo, onde a média de $\mathrm{pH}$ 4,82 impediu a disponibilidade em excesso do nutrientes para as plantas em estudo.

Por outro lado, Queiroz et al. (2004) trabalhando com capim Tifton 85 submetido à aplicação de água residuária de suinocultura e água da rede de abastecimento, obteve valores médios de 0,37 e 0,34 dag kg-1 , respectivamente, de concentração de fósforo total nas folhas.

Com base nos resultados do estudo do acúmulo de fósforo em função das forrageiras e dos cortes na Tabela 3, observa-se que o capim Marandu apresentou as maiores médias em relação aos capins Tifton seguido do Pojuca dentro de cada corte. Por outro lado, entre os cortes as três forrageiras apresentaram maior extração de fósforo no segundo corte.

A diferença de acúmulo de fósforo pelas forrageiras entre os cortes se justifica pelo efeito concentração do fósforo nas plantas, onde este estava mais facilmente disponível devido a maior presença do elemento no solo, o que ocorreu no final do experimento (Tabela 4).

$\mathrm{Na}$ disposição dos esgotos no solo por escoamento superficial, a remoção do fósforo dá-se: por precipitação química com alumínio e ferro e na forma de fosfato de cálcio, $\mathrm{Ca}_{3}\left(\mathrm{PO}_{4}\right)_{2}$ por adsorção no complexo de troca e na superfície das argilas, e por absorção pela vegetação em crescimento nas rampas de tratamento (Paganini, 1997). Para que este último fator de remoção do fósforo possa ser potencializado, recomenda-se que a frequência de cortes e a retirada da biomassa sejam as mais numerosas possíveis, minimizando sua concentração no solo da área de tratamento e, assim, possibilitando maior sustentabilidade ao sistema (Loures et al., 2006) 
Tabela 4. Atributos químicos do solo antes e após a aplicação das doses de ED para cada forrageira em estudo.

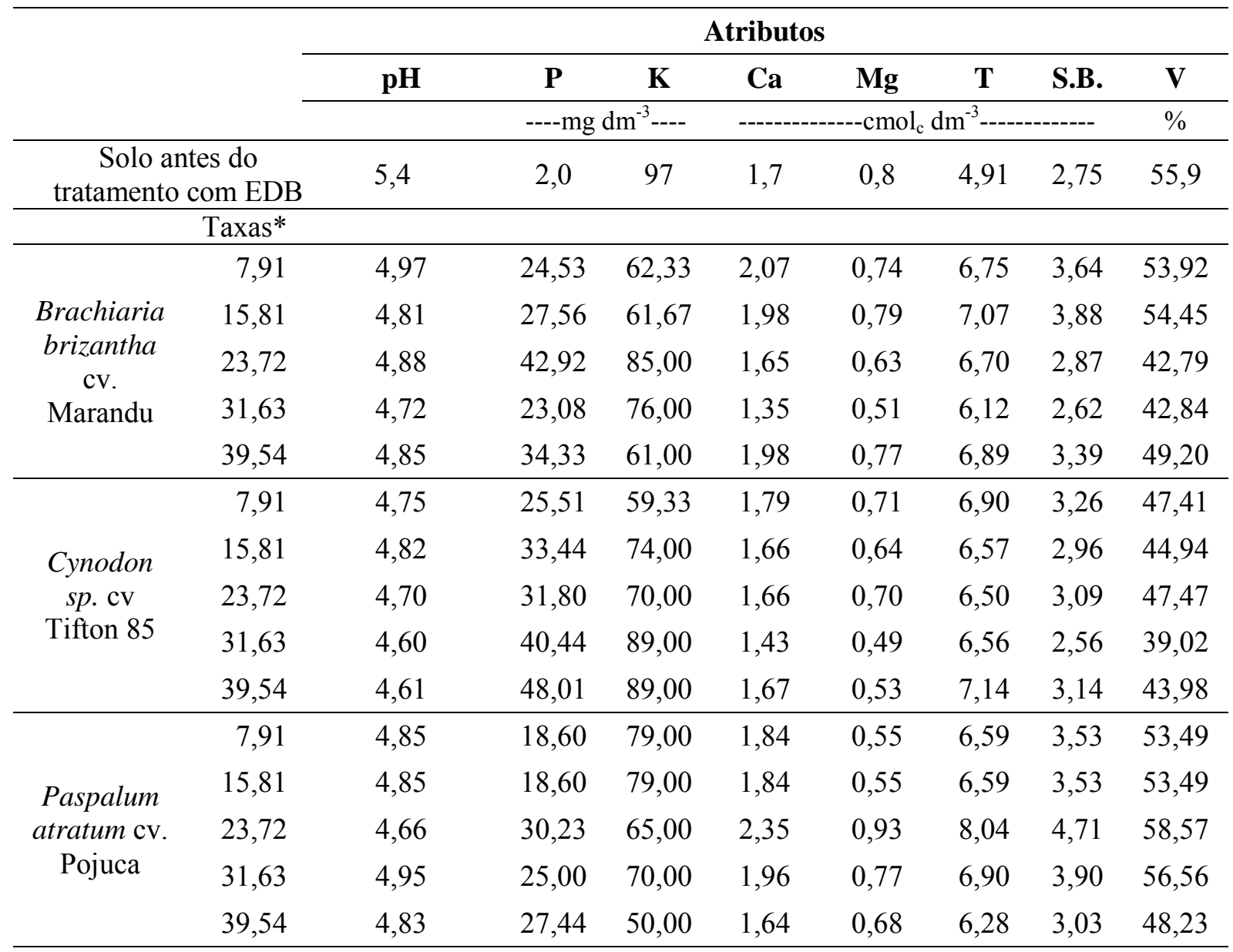

*Taxas $\left(\mathrm{kg} \mathrm{ha}^{-1} \mathrm{dia}^{-1}\right)$; EMBRAPA (1997).

Matos et al. (2010), avaliando o capim Tifton 85, verificaram sua eficiência de adaptação nos sistemas alagados construídos, para o tratamento de águas residuárias de laticínios, justamente porque a forrageira foi capaz de remover grandes quantidades de fósforo. Porém, no presente trabalho observa-se que o capim Marandu obteve um maior acúmulo de fósforo que o capim Tifton 85, o que se explica pela diferença media do $\mathrm{pH}$ para cada uma das forrageiras, mesmo os valores de $\mathrm{pH}$ se apresentando baixo, ao relacionar o $\mathrm{pH}$ do solo do capim Marandu média de 4,85 e do capim Tifton 85 média de 4,65 o valor um pouco mais elevado para capim Marandu pode ter influenciado na disponibilidade de fósforo para as plantas.

Haddad e Castro (1998) apresentaram uma revisão de trabalhos envolvendo espécies de forrageiras passíveis de serem fenadas e suas características nutricionais em função da idade de corte. Para o capim Coastcross, foi encontrado um teor de fósforo de $0,2 \mathrm{dag} \mathrm{kg}^{-1}$, nos cortes efetuados aos 40 e 50 dias de idade; este valor é $32 \%$ inferior à concentração média mais baixa obtida neste trabalho, sob a menor taxa de aplicação $7,91 \mathrm{~kg} \mathrm{ha}^{-1} \mathrm{dia}^{-1}$.

Fonseca et al. (2000), em estudo conduzido com o capim Coastcross e aplicação de esgoto doméstico, verificou concentrações médias de fósforo de $0,37 \mathrm{dag} \mathrm{kg}^{-1}$, sob a taxa de aplicação $0,24 \mathrm{~m}^{3} \mathrm{~h}^{-1} \mathrm{~m}^{-1}$; de $0,38 \mathrm{dag} \mathrm{kg}^{-1}$, sob a taxa $0,36 \mathrm{~m}^{3} \mathrm{~h}^{-1} \mathrm{~m}^{-1}$ e de $0,22 \mathrm{dag} \mathrm{kg}^{-1}$ para a testemunha. Em comparação com este trabalho apenas a testemunha foi $25 \%$ inferior aos valores da menor taxa de aplicação de ED de 7,91 $\mathrm{kg} \mathrm{ha}^{-1}$ dia $^{-1}$, com acúmulo de 15,98 $\mathrm{kg} \mathrm{ha}^{-1}$ $\left(0,29 \mathrm{dag} \mathrm{kg}^{-1}\right)$. 
Na Figura 1C nota-se que o efeito linear para o acúmulo de potássio das taxas de aplicação de ED em cada cultivar estudada, onde o acúmulo de potássio mostrou diferença entre as forrageiras estuda, uma das possíveis explicações é a forma de absorção de cada elemento pelo cultivar. O capim Tifton 85 é reconhecido como um cultivar de elevada exigência nutricional, consequentemente de alto valor nutritivo e grande capacidade de absorção de nutrientes. A Brachiaria sp. é altamente resistente e competidora, podendo se adaptar a adversas condições de nutrientes e o capim Pojuca se adapta em condições de elevado lençol freático, e possivelmente, a grandes taxas de material orgânico como aporte de nutrientes.

Em comparação com estudos realizados por Werner et al. (1996), observa-se que a capacidade de absorção de nutrientes das forrageiras estão adequadas, onde o capim Marandu obteve média de $114,4 \mathrm{~kg} \mathrm{ha}^{-1}\left(1,65 \mathrm{dag} \mathrm{kg}^{-1}\right)$, capim Tifton 85 de $195 \mathrm{~kg} \mathrm{ha}^{-1}\left(1,41 \mathrm{dag} \mathrm{kg}^{-1}\right)$ e capim Pojuca de $73,8 \mathrm{~kg} \mathrm{ha}^{-1}\left(1,39 \mathrm{dag} \mathrm{kg}^{-1}\right)$, sendo os níveis adequados Tifton 85 de 1,3-3,0 dag $\mathrm{kg}^{-1}$ e Brachiaria 1,2-3,0 dag $\mathrm{kg}^{-1}$. Dessa forma, as taxas de aplicação de ED, forneceram quantidades adequadas de potássio passível de ser absorvido pelos cultivares, ou seja, a menor taxa de aplicação forneceu a concentração de potássio para desenvolvimento dos cultivares.

Estes resultados corroboram com trabalho de Erthal et al. (2010), ao avaliar capim Tifton 85 e aveia preta sobre taxas de água residuária de bovinocultura e água (sem adição efluente), onde a concentração de potássio foi semelhante em ambos os trabalhos quando aplicação de efluente. Logo, mostra o elevado aporte de potássio ao uso efluente, seja de origem doméstica ou animal, evidenciando assim uma fonte deste para adubação das forrageiras.

Para a taxa de aplicação do ED (Figura 1D), nota-se a relação linear no acúmulo de cálcio com o aumento das taxas de aplicação de ED. A elevação do acúmulo é em função do decorrente aumento da oferta de cálcio com o incremento das doses de aplicação do ED (Tabela 4). Resultados semelhantes foram descritos por Erthal et al. (2010), para o capim Tifton 85 sob crescentes taxas de efluente de bovinocultura.

O capim Pojuca obteve as maiores médias em relação ao capim Marandu e Tifton no primeiro corte, onde no segundo corte todas as forrageiras não mostraram diferenciação entre médias. Por outro lado o capim Tifton e capim Pojuca apresentaram as maiores médias no primeiro corte que no segundo, já o capim Marandu manteve o padrão de extração de cálcio entre os dois cortes (Tabela 3).

Os resultados deste trabalho estão adequados quanto às exigências nutricionais de todas as forrageiras estudas, segundo Werner et al. (1996). No geral, os valores obtidos para o capim Tifton estão semelhantes aos relatados nos trabalhos de Queiroz et al. (2001); Oliveira et al. (2000) e Ribeiro et al. (2000).

Os valores de acúmulo de magnésio diferiram do primeiro para o segundo corte em todas as forrageiras avaliadas (Tabela 3 ). Onde no primeiro corte o capim Pojuca diferiu dos demais. Já para o segundo corte apenas o capim Marandu diferiu o acúmulo de magnésio das demais. Estes resultados se explicam possivelmente como para os demais nutrientes descritos pelas características agronômicas de cada cultivar em estudo, como por exemplo, ao processo fotossintético de cada espécie. O magnésio possui importante papel na síntese protéica, atua como ativador enzimático, além de participar da constituição da molécula de clorofila, onde em cada espécie é requerido em proporções diferentes (Malavolta, 1980).

Ressaltando neste trabalho que o capim Tifton 85 , foi o cultivar de menor extração do magnésio no primeiro corte, fato este não observado para os demais elementos já mencionados, uma vez que se espera uma alta extração pelo cultivar, devido a sua elevada exigência nutricional. Porém, em estádios de crescimento mais avançados, o metabolismo das plantas é reduzido, interferindo na absorção de alguns elementos, fato este que pode ter 
ocorrido com o cultivar em estudo. Outro fator a considerar é a competição do magnésio com cálcio, ou seja, maior competição do $\mathrm{H}^{+}$com os cátions.

A redução nos teores de magnésio com a idade pode também estar relacionado provavelmente com o processo natural de diluição do elemento na quantidade de matéria seca produzida. Resultados semelhantes foram encontrados por Oliveira et al. (2000) avaliando o valor nutricional do capim Tifton 85 , onde os autores observaram diminuição dos teores de magnésio após os 14 dias de desenvolvimento da planta.

Queiroz et al. (2004), ao avaliarem o acúmulo de magnésio em rampas de escoamento superficial, observaram também maior acúmulo pelo capim Brachiaria, em ambos os tratamentos com água residuária de suinocultura, em relação ao capim Tifton 85 .

De acordo com os resultados obtidos os valores de acúmulo de magnésio estão dentro da faixa nutricional considerada adequada por Werner et al. (1996) que é de $\left(0,15-0,4 \mathrm{dag}_{\mathrm{kg}}{ }^{-1}\right)$, e os valores médios para as forrageiras estudadas ficaram em torno de $26,78 \mathrm{~kg} \mathrm{ha}^{-1}(0,39 \mathrm{dag}$ $\left.\mathrm{kg}^{-1}\right)$ para o capim Marandu, 16,66 kg ha ${ }^{-1}\left(0,24 \mathrm{dag} \mathrm{kg}^{-1}\right)$ para o capim Tifton e 25,28 $\mathrm{kg} \mathrm{ha}^{-1}$ $\left(0,38 \mathrm{~kg} \mathrm{ha}^{-1}\right)$ para capim Pojuca. Porém, superiores aos encontrados por Queiroz et al. (2001) para forrageiras sob aplicação de efluente de suinocultura.

Em trabalho desenvolvido por Erthal et al. (2010), ao avaliar capim Tifton 85 e aveia preta sobre taxas de água residuária de bovinocultura e água (sem adição efluente), todos os resultados encontrados pelos autores independente dos tratamentos aplicados e tipo de irrigação, os valores de magnésio ficaram bem abaixo dos relatos neste experimento, onde para o capim Tifton 85 a maior média apresentada foi de $0,19 \mathrm{~kg} \mathrm{ha}^{-1}$ e para aveia-preta de $0,06 \mathrm{~kg} \mathrm{ha}^{-1}$, os menores valores encontrados podem ser em função da quantidade do nutriente presente na água residuária de bovinocultura, assim como a interação desta com o tipo de solo utilizado um Argissolo Vermelho Escuro Eutrófico Tb.

$\mathrm{Na}$ Tabela 3 para o enxofre, observa-se que o capim Marandu diferiu ao logo dos períodos de avaliação, e no segundo corte o capim Tifton 85 diferiu dos demais cultivares avaliados. Essa relevância de acúmulo do Tifton 85 se deve principalmente ao fato deste cultivar ser uma planta com elevada exigência nutricional, fazendo que mecanismos intrínsecos da planta, como por exemplo, sistemas radiculares muito desenvolvidos absorvam enxofre da água utilizada na irrigação ou do solo.

Ferreira et al. (2003) mostra que a utilização do lodo oriundo de estações de tratamento de despejos de curtume, como fonte de matéria orgânica e nutriente no solo, pode ser recomendada pelo valor corretivo e fertilizante que estes apresentam, bem como pela capacidade da macro e microbiota do solo de decompor os materiais orgânicos. Logo, o acúmulo de enxofre pelas forrageiras está associado ao aporte e a disponibilidade deste para as plantas, devido ao processo de mineralização (Souza et al., 2005).

\section{CONCLUSÃO}

Todas as taxas de aplicação de esgoto doméstico forneceram nutrientes necessários aos cultivares estudados, onde o incremento das taxas foi correspondente ao desenvolvimento das forrageiras. Ressalta-se apenas uma exceção ao cultivar Marandu, onde a menor taxa de aplicação de esgoto doméstico bruto foi a que proporcionou o maior acúmulo de potássio pelas plantas.

O acúmulo de nutrientes em função das taxas de aplicação de esgoto doméstico $(7,91$; 15,$82 ; 23,73 ; 31,64$ e $39,55 \mathrm{~kg} \mathrm{ha}^{-1}$ dia $^{1}$ de DBO) para os cultivares Marandu, Tifton $85 \mathrm{e}$ Pojuca estão acima dos mencionados em literatura para nitrogênio, fósforo, enxofre, manganês, ferro e cobre. Já para potássio, cálcio e magnésio estão de acordo com os valores médios relatados para as forrageiras. Logo, a utilização do esgoto doméstico nestas gramíneas 
é uma importante alternativa para aproveitamento e destinação deste resíduo, com valores de acúmulo de nutrientes adequados para desenvolvimento dos cultivares.

\section{AGRADECIMENTOS}

Ao Conselho Nacional de Desenvolvimento Científico e Tecnológico (CNPq) e Fundação de Amparo à Pesquisa do Espírito Santo (FAPES) pelo auxílio financeiro no desenvolvimento da pesquisa.

\section{REFERÊNCIAS}

AMERICAN PUBLIC HEALTH ASSOCIATION - APHA; AMERICAN WATER WORKS ASSOCIATION - AWWA; WATER ENVIRONMENT FEDERATON - WEF. Standard methods for the examination of water and wastewater. 14. ed. Washington, DC., 1999.

BERTONCINI, E. I. Tratamento de efluentes e reuso da água no meio agrícola. Revista Tecnologia \& Inovação Agropecuária, São Paulo, v. 1, n . 1, p. 152-169, 2008.

DRUMOND, L. C. D.; ZANINI, J. R.; AGUIAR, A. P. A.; RODRIGUES, G. P.; FERNANDES, A. L. T. Produção de matéria seca em pastagem de tifton 85 irrigada, com diferentes doses de dejeto líquido de suíno. Engenharia Agrícola, Jaboticabal, v. 26, n. 2, p. 426-433, 2006. http://dx.doi.org/10.1590/S0100-69162006000200009

EMPRESA BRASILEIRA DE PESQUISA AGROPECUÁRIA - EMBRAPA. Manual de análises de solo. Rio de Janeiro: EMBRAPA/SNCS, 1997. 212p.

EMPRESA BRASILEIRA DE PESQUISA AGROPECUÁRIA - EMBRAPA. Manual de análises químicas de solo, plantas e fertilizantes. Brasília: Embrapa Comunicação para transferência tecnologia, 1999. 370p.

ERTHAL, V. J. T.; FERREIRA, P. A.; PEREIRA, O. G.; MATOS, A. T. Características fisiológicas, nutricionais e rendimento de forrageiras fertirrigadas com água residuária de bovinocultura. Revista Brasileira de Engenharia Agrícola e Ambiental, Campina Grande, v. 14, n. 5, p. 458-466, 2010. http://dx.doi.org/10.1590/S141543662010000500002

FEIGIN, A.; RAVINA, I.; SHALHEVET, J. Irrigation with treated sewage effluent: management for environmental protection. Berlin: Springer-Verlag, 1991. 224p.

FERREIRA, A. S. et al. Alterações de atributos químicos e biológicos de solo e rendimento de milho e soja pela utilização de resíduos de curtume e carbonífero. Revista Brasileira de Ciências do Solo, Viçosa, v. 27, n. 4, p. 755-763, 2003. http://dx.doi.org/10.1590/S0100-06832003000400020

FONSECA, S. P. P.; SOARES, A. A.; CHERNICHARO, C. L.; VIANNA, M. R.; MATOS, A. T. Comparação de metodologias para dimensionamento do tratamento de esgoto doméstico pelo método de escoamento superficial. In: CONGRESSO INTERAMERICANO DE ENGENHARIA SANITÁRIA E AMBIENTAL, 2000, Porto Alegre. Anais... Porto Alegre: [s.n.], 2000.

GALZERANO, L.; MORGADO, E. Influence of Nitrogen on yield and quality of Tifton 85 (Cynodon spp.) grass. Revista Electrónica de Veterinária, Málaga, v. 8, n. 2, p. 1-8, 2007. 
HADDAD, C. M.; CASTRO, F. G. F. Produção de feno. In: SIMPÓSIO SOBRE MANEJO DA PASTAGEM, 15., 1998, Piracicaba. Anais... Piracicaba: FEALQ, 1998. p. 151.

LOURES, A. P. S.; SOARES. A. A.; MATOS. A. T. de; CECON. P. R.; PEREIRA. O. G. Remoção de fósforo em sistemas de tratamento de esgoto doméstico, por escoamento superficial. Revista Brasileira de Engenharia Agrícola e Ambiental, Campina Grande, v. 10, n. 3, p. 706-714, 2006. http://dx.doi.org/10.1590/S141543662006000300025

MALAVOLTA, E. Elementos de nutrição mineral de plantas. São Paulo: Agronômica Ceres, 1980. 251p.

MATOS, A. T.; ABRAHÃO, S. S.; PAOLA A. V. Lo M.; SARMENTO, A. P.; MATOS, M. P. de. Capacidade extratora de plantas em sistemas alagados utilizados no tratamento de águas residuárias de laticínios. Revista Brasileira de Engenharia Agrícola e Ambiental, Campina Grande, v. 14, n. 12, p. 1311-1317, 2010. http://dx.doi.org/10.1590/S1415-43662010001200009

MELO, W. J.; MARQUES, M. O. Potencial do lodo de esgoto como fontes de nutrientes para as plantas. In: BETTIOL, W.; CAMARGO, O. A. (Org.). Impacto ambiental do uso agrícola do lodo de esgoto. Jaguariúna: EMBRAPA, 2000. Cap. 5. p. 109-141.

OLIVEIRA, M. A.; PEREIRA, O. G.; GARCIA, R.; OBEID, J. A.; CECON, P. R.; MORAES, S. A. et al. Rendimento e valor nutritivo do capim tifton 85 (Cynodon spp.) em diferentes idades de rebrota. Revista Brasileira de Zootecnia, Piracicaba, v. 29, n. 6, p. 1949-1960, 2000.

PAGANINI, W. S. Disposição de esgoto no solo, através de escoamento à superfície, com utilização de gramíneas: avaliação do processo quanto aos aspectos sanitários, operacionais, construtivos e de manutenção. 1997. 197f. Dissertação (Mestrado em Engenharia Civil) - Programa de Pós-graduação em Engenharia Civil, Universidade de São Paulo, 1997.

PRIMAVESI, A. C.; PRIMAVESI, ODO.; CORRÊA, L. de A.; CANTARELLA, H.; SILVA, A. G. da; FREITAS, A. R. de et al. Adubação nitrogenada em Capim-Coastcross: efeitos na extração de nutrientes e recuperação aparente do nitrogênio. Revista Brasileira de Zootecnia, Piracicaba, v. 33, n. 1, p. 68-78, 2004. http://dx.doi.org/10.1590/S1516-35982004000100010

QUEIROZ, F. M.; MATOS, A. T.; PEREIRA, O. G.; OLIVEIRA, R. A. The dry matter yield of forage-grass species in overland flow treatment using swine wastewater. In: SOARES, A. A.; SATURNINO, H. M. (Org.). Enviroment and the water: competitive use and conservation strategies for water and natural resources. Brasília: ABID, 2001. P. 166-172.

QUEIROZ, F. M.; MATOS, A. T.; PEREIRA, O. G.; OLIVEIRA, R. A.; LEMOS, A. F. Características químicas do solo e absorção de nutrientes por gramíneas em rampas de tratamento de águas residuárias da suinocultura. Engenharia na Agricultura, Viçosa, v. 12, n. 2, p. 77-90, 2004.

RIBEIRO, K. G.; PEREIRA, O. G.; GARCIA, R.; VALADARES FILHO, S. C.; CECON, P. R. Composição e extração mineral do capim-tifton 85, em três idades de rebrota, sob cinco doses de nitrogênio. In: REUNIÃO ANUAL DA SOCIEDADE BRASILEIRA DE ZOOTECNIA, 37., 2000, Viçosa. Anais... Viçosa: SBZ, 2000. p. 55. 
RIBEIRO, M. S. et al. Efeitos de águas residuárias de café no crescimento vegetativo de cafeeiros em seu primeiro ano. Engenharia Agrícola, Jaboticabal, v. 29, n. 4, p 569-577, 2009. http://dx.doi.org/10.1590/S0100-69162009000400007

SILVA NETO, S. P.; SILVA, J. E. C.; SANTOS, A. C.; CASTRO, J. G. D.; DIM, V. P.; ARAÚJO, A. dos S. Características agronômicas e nutricionais do capim-Marandu em função da aplicação de resíduo líquido de frigorífico. Acta Scientiarum. Animal Sciences, Maringá, v. 32, n. 1, p. 9-17, 2010.

SILVA, D. J.; QUEIROZ, A. C. Análise de alimentos (métodos químicos e biológicos). 3. ed. Viçosa, MG: UFV, 2002. 235 p.

SOUZA, E. R. B. de; BORGES, J. D.; LEANDRO, W. M.; OLIVEIRA JÚNIOR, J. P. de; OLIVEIRA, I. P. de; XIMENES, P. A. et al. Teores de metais tóxicos nas folhas de plantas de milho fertilizadas com lodo de curtume. Pesquisa Agropecuária Tropical, v. 35, n. 2, p. 117-122, 2005.

VON SPERLING, M. Princípios básicos do tratamento de esgotos. Belo Horizonte: Departamento de Engenharia sanitária e ambiental. Universidade Federal de Minas Gerais, 1996. Vol. 2, 211p.

WERNER, J. C.; PAUlinO, V. T.; CANTARELla, H.; ANDRADE, N. O.; QUAGGIO, J. A. Forrageiras. In: RAIJ, B. Van; CANTARELA, H.; QUAGGIO, J. A.; FURLANI, A. M. C. (Ed.). Recomendações de adubação e calagem para o Estado de São Paulo. 2. ed. Campinas: Fundação IAC, 1996. p. 263-274. (IAC Boletim Técnico, 100). 


\begin{tabular}{c}
$\begin{array}{c}\text { Ambiente \& Água - An Interdisciplinary Journal of Applied Science } \\
\text { ISSN 1980-993X - doi:10.4136/1980-993X } \\
\text { www.ambi-agua.net } \\
\text { E-mail: ambi-agua@agro.unitau.br }\end{array}$ \\
\hline
\end{tabular}

\title{
Viabilidade do uso de água residuária tratada na irrigação da cultura do rabanete (Raphanus sativus L.)
}

\author{
doi: 10.4136/ambi-agua.1220
}

Received: 20 Oct 2013; Accepted: 08 Mar 2014

\author{
Iasmine Louise de Almeida Dantas ${ }^{1 *}$; Gregorio Guirado Faccioli ${ }^{1}$; \\ Luciana Coêlho Mendonça ${ }^{2}$; Tatiana Pacheco Nunes ${ }^{3}$; \\ Pedro Roberto Almeida Viegas ${ }^{1}$; \\ Larissa Oliveira Gama de Santana ${ }^{1}$ \\ ${ }^{1}$ Universidade Federal de Sergipe (UFS) - São Cristovão, SE, Brasil \\ Departamento de Engenharia Agronômica (DEA) \\ ${ }^{2}$ Universidade Federal de Sergipe (UFS) - São Cristovão, SE, Brasil \\ Departamento de Engenharia Civil (DEC) \\ ${ }^{3}$ Universidade Federal de Sergipe (UFS) - São Cristovão, SE, Brasil \\ Departamento de Engenharia de Alimentos \\ *Autor correspondente: e-mail: iasminedantas@gmail.com, \\ gregorioufs@gmail.com, lumendon@uol.com.br, tpnunes@uol.com.br, \\ pviegas@ufs.br, larissa.ogs@gmail.com
}

\section{RESUMO}

A utilização de água residuária tratada para irrigação pode se tornar uma alternativa para regiões que enfrentam escassez de água. O presente trabalho teve como objetivo avaliar os efeitos do reuso de efluente doméstico na cultura do rabanete (Raphanus sativus L.). O experimento foi realizado em casa de vegetação do Departamento de Engenharia Agronômica (DEA), localizada na Universidade Federal de Sergipe/Campus de São Cristóvão no período de agosto a setembro de 2011. O efluente foi coletado na Estação de Tratamento de Esgotos (ETE) Rosa Elze, localizada no Município de São Cristóvão/SE. As irrigações foram feitas utilizando-se cinco diluições diferentes. A lâmina de irrigação foi obtida pelo método do Food and Agriculture Organization (FAO) 56. O delineamento experimental utilizado foi inteiramente casualizado (IC), com cinco repetições e duas plantas por parcela útil. Foram avaliados altura, massa seca e fresca da parte aérea; comprimento e massa fresca da raiz; diâmetro do fruto e número de folhas. Os dados obtidos foram submetidos à análise de variância e as médias comparadas pelo teste de Tukey ao nível de 5\% de probabilidade, não havendo diferença significativa. Em relação à qualidade microbiológica do bulbo, realizou-se a enumeração de coliformes termotolerantes, de bactérias aeróbias mesófilas e a pesquisa de Salmonella, os resultados demonstram que o rabanete encontra-se dentro dos padrões estabelecidos pela legislação.

Palavras-chave: efluente, reuso, microbiologia, agricultura.

\section{Viability of using treated wastewater for the irrigation of radish (Raphanus sativus L.)}

\begin{abstract}
The use of treated wastewater for irrigation may become an alternative for regions facing water scarcity. This study aimed to evaluate the effects of wastewater reuse in the cultivation
\end{abstract}


of radish (Raphanus sativus L.). The experiment was conducted in the greenhouse of the Department of Agricultural Engineering (DEA), located at the Federal University of Sergipe/Campus of São Cristóvão from August to September 2011. The effluent was collected at the Sewage Treatment Plant (WWTP) Rosa Elze, located in the municipality of São Cristóvão/SE. Irrigation was performed using five different dilutions, and was accomplished using the method of the Food and Agriculture Organization (FAO) 56. The experimental design was a completely randomized design (CRD) with five replications and two plants per useful plot. The study evaluated height, fresh and dry shoot matter, length and fresh weight of root, fruit diameter and number of leaves. The data were subjected to ANOVA and means were compared by the Tukey test at $5 \%$ probability, with no significant difference. Regarding the microbiological quality of the bulb, the results of the enumeration of coliforms, mesophilic aerobic bacteria and the detection of Salmonella demonstrate that the radish is within the standards established by legislation.

Keywords: effluent, reuse, microbiology, agriculture.

\section{INTRODUÇÃO}

O desenvolvimento agrícola exige novas estratégias, no sentido de potencializar a produtividade e minimizar os riscos na produção. Com o aumento da população mundial, a produção de alimentos com base apenas na estação chuvosa não é suficiente. Um dos importantes desafios da agricultura atual é o aumento da competitividade e qualidade dos produtos, associado à preservação dos recursos hídricos e do meio ambiente, permitindo benefícios sustentáveis nas explorações agrícolas. Neste contexto, é importante avaliar e adequar cada um dos fatores que compõem o sistema de produção, incluindo a eficiência e o manejo da água de irrigação.

Nas regiões áridas e semiáridas, a água se tornou um fator limitante para o desenvolvimento urbano, industrial e agrícola. Planejadores e entidades gestoras de recursos hídricos procuram, continuadamente, novas fontes de recursos para complementar à pequena disponibilidade hídrica ainda disponível (Hespanhol, 2003).

Por meio da irrigação, pode-se intensificar a produção agrícola, regularizando, ao longo do ano, as disponibilidades e os estoques de alimentos, uma vez que essa prática permite uma produção na contra estação. A atividade de irrigação é a maior consumidora de água entre os diversos usos desse recurso natural. Dentro dela, os consumos específicos variam bastante, dependendo do método de irrigação empregado. A natureza do solo, o tipo de requerimentos das diferentes culturas e os índices de evaporação locais são elementos importantes para definir o consumo de água para irrigação (Hespanhol, 2002).

A irrigação não pode e não deve competir com o uso da água destinada ao abastecimento doméstico, que sempre será prioridade. Pela Constituição Brasileira, a ordem de prioridade do uso da água é a seguinte: consumo humano, indústria e, por fim, irrigação. Assim, as águas utilizadas em irrigação são cada vez mais escassas e de pior qualidade. Essa realidade demanda uma busca de adaptação das técnicas de irrigação existentes e amplamente difundidas às condições atuais e futuras de escassez de água. Diante desse panorama é clara a necessidade de se utilizar esse recurso natural com maior racionalidade, seja através de técnicas que permitam um aproveitamento mais eficiente da água em diversas atividades humanas, como a irrigação ou pela busca de fontes alternativas de água (Duarte, 2006).

Para determinar as necessidades hídricas das culturas, o método mais usual está baseado na estimativa da evapotranspiração da cultura (ETc), que envolve um processo em duas etapas. Na primeira, estima-se a evapotranspiração de referência (ETo), geralmente utilizando uma equação empírica (determinação indireta). Na segunda, a ETc é obtida ao multiplicar 
ETo por um coeficiente de cultura $(\mathrm{kc})$ que integra as características da cultura e do clima local (Doorenbos e Pruitt, 1977; Allen ,1998).

Para entender e poder predizer a quantidade de água necessária em uma irrigação de forma precisa e acurada, o contínuo solo-planta-atmosfera deve ser considerado como um sistema dinâmico, fisicamente integrado, onde os processos de transporte ocorrem interativamente. Neste, os fatores meteorológicos de superfície controlam a força de demanda hídrica, daí um sistema de monitoramento e controle baseado em medições, em tempo real, de parâmetros ligados ao contínuo solo-planta-atmosfera devem ser usados para determinar as necessidades hídricas das culturas e estabelecer estratégias de manejo de irrigação, visando otimizar e racionalizar a utilização da água e da energia com melhoria de produtividade das culturas (Faria, 1998).

A falta de recursos hídricos e o aumento dos conflitos pelo uso da água geraram a emergência da conservação e do tratamento e reuso, como componentes formais da gestão de recursos hídricos. Os benefícios inerentes à utilização de água recuperada para usos benéficos, ao contrário de disposição ou descarga, incluem preservação de fontes de qualidade elevada, proteção ambiental e benefícios econômicos e sociais (Asano et al., 2007).

Qualquer que seja a forma de reuso empregada é fundamental observar que os princípios básicos que devem orientar essa prática são: preservação da saúde dos usuários, preservação do meio ambiente, atendimento consistente às exigências de qualidade, relacionadas ao uso pretendido e proteção dos materiais e equipamentos utilizados nos sistemas de reuso (Hespanhol, 2002).

Medeiros et al. (2008) verificaram que a irrigação com esgoto filtrado foi mais efetiva na melhoria do estado nutricional do cafeeiro que a irrigação convencional, revelando que a aplicação controlada de esgoto ao solo é uma alternativa para fertilização das culturas, potencializando a produção de alimentos. E, na irrigação com efluente sanitário tratado por diversas tecnologias de tratamento, Duarte et al. (2008) concluíram que os efluentes utilizados mostraram qualidade física e química adequada para plantas de pimentão.

A quantidade de nitrogênio adicionado ao solo por meio da irrigação com esgoto sanitário pode ser similar ou até mesmo exceder a quantidade aplicada via fertilização nitrogenada recomendada, durante períodos de tempo similares (Feigin et al., 1978 apud Medeiros et al., 2008).

Assim, a fim de assegurar a proteção dos usuários, dos alimentos produzidos e das pessoas envolvidas com os métodos de reuso de esgotos, é necessário avaliar os aspectos sanitários dessas práticas, principalmente quanto à propagação de patógenos (Daltro Filho, 2004).

A Organização Mundial da Saúde - OMS (WHO, 2006) destaca a importância da qualidade biológica dos efluentes utilizados na irrigação, para que se diminua a probabilidade de propagação de patógenos, ocasionando diversas enfermidades, e recomenda que o efluente tratado contenha menos que $10^{3} \mathrm{NMP}$ (Número Mais Provável) por $100 \mathrm{~mL}$ de coliformes termotolerantes e menos que 1 ovo de nematoide por litro para que esse efluente possa ser utilizado na irrigação irrestrita.

Segundo Pelczar Jr. et al. (1997), os micro-organismos estão intimamente associados com a disponibilidade, a abundância e a qualidade do alimento para consumo humano. Os alimentos são facilmente contaminados com micro-organismos no ambiente, durante a manipulação e o processamento. Após ter sido contaminado, o alimento serve como meio para a multiplicação de micro-organismos. Se esses micro-organismos tiverem condições de se multiplicarem, podem mudar as características físicas e químicas do alimento e podem causar sua deterioração. Os micro-organismos no alimento podem também ser responsáveis por intoxicações e infecções. 
As bactérias são os principais micro-organismos constituintes da microbiota em hortaliças. Isso ocorre, pois o valor do $\mathrm{pH}$ encontrado nesse tipo de alimento $(5,0-6,5)$ favorece a multiplicação destes micro-organismos em relação à multiplicação dos bolores e leveduras (King et al., 1991). Dessa forma, a população de micro-organismos mesófilos presente nos vegetais pode ser tão elevada quanto $10^{9} \mathrm{UFC} \mathrm{g}^{-1}$ (Unidade Formadora de Colônia por grama), mas geralmente fica entre $10^{4}$ e $10^{6}$ UFC g ${ }^{-1}$. Esta variabilidade ocorre em função das condições climáticas, da presença de animais e de insetos ou da injúria no próprio vegetal (Nguyen e Carlin, 1994).

Os micro-organismos patogênicos e deteriorantes podem contaminar os vegetais durante a pré e pós-colheita. Durante a pré-colheita, os principais focos de contaminação são: o solo, a água de irrigação, a água utilizada para aplicar fungicidas e inseticidas, a poeira, os insetos, a compostagem inadequada, os animais domésticos e selvagens e a manipulação humana. As fontes de contaminação pós-colheita incluem manipulação humana, equipamentos de colheita, embalagens de transporte, animais, insetos, poeira, água de lavagem, gelo, veículos de transporte e equipamentos durante o processo (Brackett, 1999; Beuchat, 2002).

De forma a possibilitar a investigação da irrigação com efluente tratado em um curto período de tempo, foi escolhida a cultura do rabanete que, segundo (Cardoso e Hiraki, 2001), apesar de ser uma cultura de pequena importância em termos de área plantada, é cultivado em grande número de pequenas propriedades dos cinturões verdes das regiões metropolitanas. Uma das vantagens de se cultivar esta espécie é a possibilidade de auferir ganhos durante o tempo transcorrido entre duas outras culturas de ciclo mais longo, pois além de ser relativamente rústica, apresenta ciclo muito curto (cerca de 30 dias), com retorno rápido.

Assim o presente trabalho teve o objetivo de analisar a viabilidade do uso de água residuária na irrigação do rabanete (Raphanus sativus L.).

\section{MATERIAL E MÉTODOS}

O experimento foi realizado em estufa agrícola do Departamento de Engenharia Agronômica (DEA), localizada na Universidade Federal de Sergipe/Campus de São Cristóvão (Figura 1).

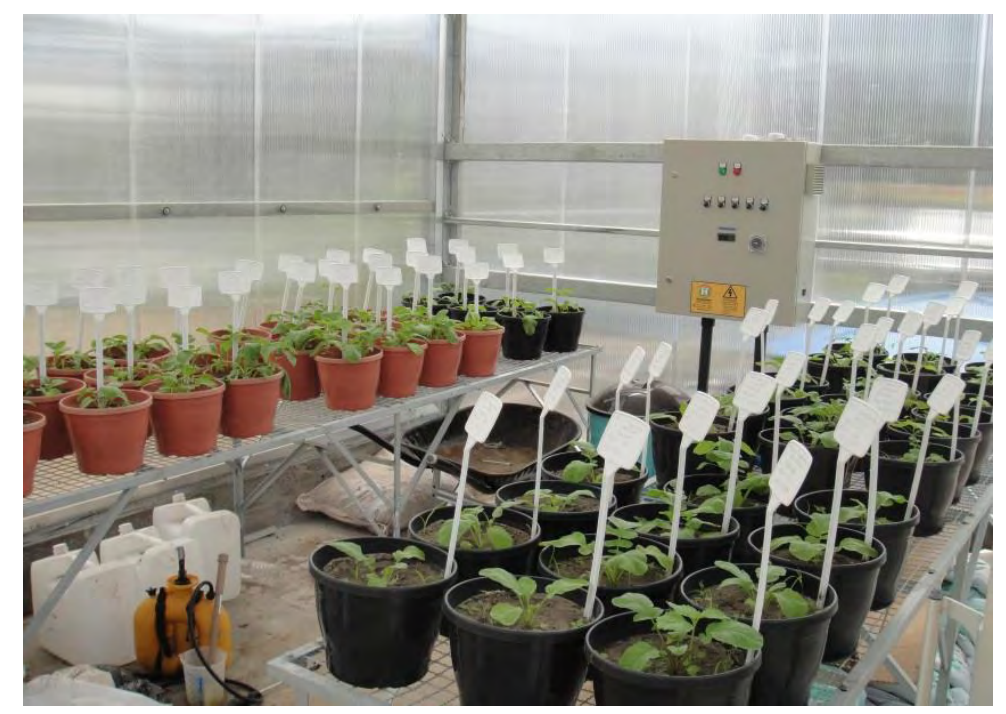

Figura 1. Esquema do experimento na casa de vegetação.

As diluições foram: T1 (100\% de água potável da Companhia de Saneamento de Sergipe - DESO); T2 (100\% de efluente); T3 (50\% de água DESO + 50\% de efluente); T4 ( $25 \%$ de água DESO $+75 \%$ de efluente) e T5 (75\% de água DESO $+25 \%$ de efluente). Foi 
utilizado o delineamento estatístico inteiramente casualizado (IC), com cinco repetições e duas plantas por parcela útil.

A semeadura foi realizada no dia 24/08/2011, utilizando-se sementes de Rabanete (Raphanus sativus L.) produzidas pela empresa Isla; o substrato utilizado foi Terra Vegetal fabricado por Organfert Fertilizantes Orgânicos LTDA- ME, a cultura agrícola foi conduzida em vasos e irrigada diariamente. Aos oito dias após a germinação, foi feito o desbaste das plântulas, quando estas apresentavam o primeiro par de folhas definitivas, deixando aquela mais vigorosa.

O efluente doméstico foi coletado semanalmente da Estação de Tratamento de Esgotos (ETE) Rosa Elze, localizada no Município de São Cristóvão/SE. A estação foi construída na década de 80 para tratar as águas residuárias geradas nos bairros residenciais Rosa Elze e Eduardo Gomes. Esse sistema de tratamento é operado e mantido pela DESO; o mesmo é constituído por cinco lagoas de estabilização em série, sendo duas facultativas e três de maturação, totalizando uma área total de 29.650 metros quadrados.

Inicialmente, o esgoto "in natura", ou seja, sem tratamento, foi coletado em um vasilhame de dois litros e foi encaminhado para análise química e fitossanitária em laboratório do Departamento de Química da Universidade Federal de Sergipe. Para coleta semanal do efluente, foram utilizados vasilhames de vinte litros, utilizados na aplicação das diluições.

Para a estimativa da demanda hídrica da cultura, foi utilizada a metodologia proposta pelo documento FAO 56, ou seja, as variáveis climáticas (temperatura, umidade relativa, radiação e velocidade do vento) foram monitoradas diariamente para dar suporte à estimativa da evapotranspiração de referência pelo método de Penman-Monteith e o coeficiente de cultivo foi estabelecido em função da fase fenológica da cultura.

A colheita foi realizada no dia 26/09/2011. Após a colheita, foram determinadas as características agronômicas (altura da parte aérea - APA, massa seca da parte aérea - MSPA e massa fresca da parte aérea - MFPA, massas fresca da raiz - MFR, diâmetro do bulbo - DB, número de folhas - NF e comprimento da raiz - $\mathrm{CR}$ ) e microbiológicas do bulbo (enumeração de coliformes termotolerantes, pesquisa de Salmonella e enumeração de bactérias aeróbias mesófilas).

Para a determinação das características agronômicas, as plantas foram lavadas e a medição de altura da parte aérea e comprimento da raiz foram realizadas utilizando-se régua. O diâmetro do bulbo foi estimado utilizando-se um paquímetro. Para obtenção dos valores das massas foi utilizada balança digital do Laboratório de Fisiologia de Pós Colheita, localizado no Departamento de Engenharia Agronômica da Universidade Federal de Sergipe.

As análises microbiológicas foram realizadas no Laboratório de Microbiologia de Alimentos no Departamento de Tecnologia de Alimentos da Universidade Federal de Sergipe.

Foram pesadas $25 \mathrm{~g}$ de cada amostra, totalizando cinco amostras referentes às cinco diluições utilizadas na irrigação. As amostras foram transferidas assepticamente para frascos contendo $225 \mathrm{~mL}$ de água peptonada e em seguida foram preparadas diluições decimais até $10^{-6}$ em água peptonada $0,1 \%$. Foram feitas duplicatas de cada amostra.

Para a análise de coliformes termotolerantes, alíquotas de $1 \mathrm{~mL}$ de cada diluição foram inoculadas em séries de três tubos contendo $9 \mathrm{~mL}$ de caldo lactosado posteriormente, os tubos foram incubados a $35^{\circ} \mathrm{C}$ por 48 horas e os tubos com leitura positiva (turvação e formação de gás), seguiram para os testes confirmativos em caldo $\mathrm{EC} \mathrm{a} 45^{\circ} \mathrm{C}$ por 48 horas (Kornacki e Johnson, 2001).

Os valores de NMP $\mathrm{g}^{-1}$ foram calculados utilizando-se a tabela de NMP para 3 séries de 3 tubos conforme Swanson et al. (2001).

Em relação à enumeração de mesófilos, a partir de cada diluição selecionada, semeou-se $1 \mathrm{~mL}$ em placas de Petri sobre a qual foi adicionado PCA. Após a completa homogeneização e solidificação do meio, as placas foram incubadas a $37^{\circ} \mathrm{C}$ por $48 \mathrm{~h}$. As placas contendo entre 
25 e 250 colônias foram contadas. Os resultados foram expressos em unidades formadoras de colônias por grama de alimento (UFC g ${ }^{-1}$ ) (Morton, 2001).

$\mathrm{Na}$ etapa de pré-enriquecimento para a análise da pesquisa de Salmonella, $25 \mathrm{~g}$ de amostra foram diluídas em $225 \mathrm{~mL}$ de caldo lactosado que posteriormente foi incubada a $37^{\circ} \mathrm{C}$ por 24 horas. Para o enriquecimento seletivo, após a incubação do pré-enriquecimento, retiraram-se alíquotas de $0,1 \mathrm{~mL}$ e $1.0 \mathrm{~mL}$ do caldolactosado as quais foram adicionadas em dois meios seletivos distintos, Rappaport-Vassiliadis e o caldo Tetrationato a $42^{\circ} \mathrm{C}$ e $37^{\circ} \mathrm{C}$, respectivamente. Em seguida, semeou-se esse inóculo em meio seletivo diferencial de ágar Hektoen Enteric (HE- Oxoid) e ágar Xilose-Lisina Desoxicolato (XLD) e incubados a $37^{\circ} \mathrm{C}$ por 24 horas de forma a obter colônias típicas. As colônias típicas foram confirmadas através de provas bioquímicas.

A análise estatística foi feita utilizando-se o programa de estatística SISVAR da Universidade Federal de Lavras. Os dados foram submetidos à Anova e as médias pelo teste de Tukey, a $5 \%$ de probabilidade.

\section{RESULTADOS E DISCUSSÃO}

Observam-se na Tabela 1 os valores dos parâmetros analisados na água do efluente.

Tabela 1. Análise fisicoquímica do efluente realizada no Laboratório de Química Ambiental da UFS.

\begin{tabular}{c|lcccc}
\hline Data & Amostra & $\mathbf{p H}$ & $\begin{array}{c}\text { N-Total } \\
\left(\mathrm{mg} \mathrm{L}^{-1}\right)\end{array}$ & $\begin{array}{c}\text { Sólidos Totais } \\
\text { Dissolvidos } \\
(\mathrm{pmm})\end{array}$ & $\begin{array}{c}\text { P-Total } \\
\left(\mathrm{mg} \mathrm{L}^{-1}\right)\end{array}$ \\
\hline \multirow{2}{*}{$30 / 08 / 11$} & Entrada* & 7,4 & 82,3 & 183,33 & 18,70 \\
& Saída** & 7,3 & 33,1 & 13,16 & 13,20 \\
\hline \multirow{2}{*}{$13 / 09 / 11$} & Entrada* & 7,5 & 99,6 & 109,52 & 29,90 \\
& Saída** & 7,7 & 26,7 & 466,67 & 14,08 \\
\hline \multirow{2}{*}{$20 / 09 / 11$} & Entrada* & 7,7 & 98,2 & 208,33 & 22,80 \\
& Saída** & 7,7 & 36,1 & 73,33 & 14,80 \\
\hline
\end{tabular}

Nota: "Entrada: valores do afluente coletado na entrada da lagoa de maturação.

***Saída: valores do efluente coletado na saída da lagoa de maturação.

Na Tabela 1, observa-se que o efluente do sistema de lagoas é levemente ácido e que ocorre remoção de nutrientes (nitrogênio e fósforo) e sólidos dissolvidos. Na amostra do efluente de 13/09/11, pode ter ocorrido alguma contaminação da amostra ou ter sido coletada juntamente com algum lodo flotado, ocasionando valor elevado de sólidos. Os nutrientes remanescentes presentes nas amostras do efluente podem vir a beneficiar a necessidade nutricional da cultura irrigada com esse efluente.

Durante a realização deste experimento, Ramiro et al. (2012) analisaram a qualidade do sistema de lagoas de estabilização e verificaram que não foram encontrados ovos de helmintos no efluente do sistema de tratamento, durante o monitoramento microbiológico realizado no período.

$\mathrm{Na}$ Tabela 2, são apresentados os resultados das análises agronômicas realizadas no rabanete. 
Tabela 2. Médias das variáveis analisadas.

\begin{tabular}{c|ccccccc}
\hline Diluições & $\begin{array}{c}\text { MFPA } \\
(\mathrm{g})\end{array}$ & $\begin{array}{c}\text { MFR } \\
(\mathrm{g})\end{array}$ & $\begin{array}{c}\text { APA } \\
(\mathrm{cm})\end{array}$ & $\begin{array}{c}\mathbf{C R} \\
(\mathrm{cm})\end{array}$ & $\begin{array}{c}\text { DB } \\
(\mathrm{cm})\end{array}$ & $\mathbf{N F}$ & $\begin{array}{c}\text { MSPA } \\
(\mathrm{g})\end{array}$ \\
\hline $\mathbf{1}$ & $8,75 \mathrm{a}$ & $12,11 \mathrm{a}$ & $19,37 \mathrm{a}$ & $9,52 \mathrm{a}$ & $2,76 \mathrm{a}$ & $6,3 \mathrm{a}$ & $0,8175 \mathrm{a}$ \\
$\mathbf{2}$ & $10,26 \mathrm{a}$ & $16,39 \mathrm{a}$ & $19,69 \mathrm{a}$ & $9,11 \mathrm{a}$ & $3,04 \mathrm{a}$ & $6,4 \mathrm{a}$ & $0,8395 \mathrm{a}$ \\
$\mathbf{3}$ & $12,06 \mathrm{a}$ & $14,19 \mathrm{a}$ & $21,07 \mathrm{a}$ & $8,82 \mathrm{a}$ & $2,89 \mathrm{a}$ & $6,5 \mathrm{a}$ & $0,9660 \mathrm{a}$ \\
$\mathbf{4}$ & $10,93 \mathrm{a}$ & $14,00 \mathrm{a}$ & $20,61 \mathrm{a}$ & $8,42 \mathrm{a}$ & $3,14 \mathrm{a}$ & $6,4 \mathrm{a}$ & $0,8721 \mathrm{a}$ \\
$\mathbf{5}$ & $9,72 \mathrm{a}$ & $12,05 \mathrm{a}$ & $20,28 \mathrm{a}$ & $7,80 \mathrm{a}$ & $2,62 \mathrm{a}$ & $6,3 \mathrm{a}$ & $0,8159 \mathrm{a}$ \\
$* \mathbf{C V} \%$ & 19,30 & 27,02 & 9,33 & 11,73 & 14,75 & 8,46 & 23,27 \\
\hline
\end{tabular}

Nota: *CV: coeficiente de variância.

Observa-se na Tabela 2 que não ocorreu diferenças significativas a 5\% de probabilidade pelo teste de Tukey de todas as variáveis analisadas.

Na Tabela 3 é mostrada a população dos micro-organismos presentes no rabanete.

Tabela 3. Resultados obtidos para UFC $\mathrm{g}^{-1}$ de mesófilos, NMP $\mathrm{g}^{-1}$ de coliformes termotolerantes e ausência em $25 \mathrm{~g}$ de Salmonella.

\begin{tabular}{|c|c|c|c|c|c|}
\hline \multirow{2}{*}{ Micro-organismos } & \multicolumn{5}{|c|}{ Diluições } \\
\hline & 1 & 2 & 3 & 4 & 5 \\
\hline Mesófilos (UFC.g $\mathrm{g}^{-1}$ ) & $1,9 \times 10^{6}$ & $1,9 \times 10^{6}$ & $1,9 \times 10^{6}$ & $1,9 \times 10^{6}$ & $1,9 \times 10^{6}$ \\
\hline Coliformes termotolerantes (NMP g ${ }^{-1}$ ) & $\leq 3$ & $\leq 3$ & $\leq 3$ & $\leq 3$ & $\leq 3$ \\
\hline Salmonella (ausência em 25g) & ausente & ausente & Ausente & ausente & ausente \\
\hline
\end{tabular}

Verifica-se, na Tabela 3, que os valores encontrados estão dentro dos padrões estabelecidos pela Resolução ANVISA $n^{0} 12$ (Brasil, 2001), que preconiza a ausência de Salmonella em 25 gramas e a população máxima de $10^{3} \mathrm{NMP}^{-1}$ de coliformes termotolerantes.

Os resultados obtidos corroboram com os obtidos por Carvalho et al. (2013) que também obtiveram ausência de Salmonella e coliformes menores que 3 NMP g ${ }^{-1}$, no estudo da irrigação de girassol com efluente tratado no mesmo sistema de lagoas de estabilização.

\section{CONCLUSÃO}

O efluente mostrou-se viável na irrigação da cultura do rabanete não apresentando diferença entre os tratamentos com relação às variáveis agronômicas e, principalmente, os valores encontrados dos patógenos serem aceitos pela Resolução ANVISA $n^{\circ} 12$ (Brasil, 2001). 


\section{REFERÊNCIAS}

ALLEN, R. G. et al. Crop evapotranspiration - Guidelines for computing crop water requirements. Rome: FAO, 1998. (FAO Irrigation and Drainage, 5).

ASANO, T. et al. Water reuse, issues, technologies, and applications. New York: Metcalf \& Eddy/AECOM; McGraw Hill, 2007.

BEUCHAT, L. R. Ecological factors influencing survival and growth of human pathogens on raw fruits and vegetables. Microbes and Infection, v. 4, p. 413-423, 2002. http://dx.doi.org/10.1016/S1286-4579(02)01555-1

BRACKETT, R. E. Incidence, contributing factors, and control of bacterial pathogens in produce. Postharvest Biology and Technology, v. 15, p. 305-311, 1999. http://dx.doi.org/10.1016/S0925-5214(98)00096-9

BRASIL. Agência Nacional de Vigilância Sanitária. Resolução RDC no 12, de 02 de janeiro de 2001. Aprova o Regulamento Técnico sobre padrões microbiológicos para alimentos. Diário Oficial [da] União; Poder Executivo, de 10 de janeiro de 2001

CARDOSO, A. I. I.; HIRAKI, H. Avaliação de doses e épocas de aplicação de nitrato de cálcio em cobertura na cultura do rabanete. Horticultura Brasileira, Brasília, v. 19, n. 3, p. 196-199, novembro 2001.

CARVALHO, R. S.; SANTOS FILHO, J. S.; SANTANA, L. O. G.; GOMES, D. A.; MENDONÇA, L. C.; FACCIOLI, G. G. Influência do reuso de águas residuárias na qualidade microbiológica do girassol destinado à alimentação animal). Revista Ambiente \& Água, v. 8, n. 2, p. 157-167, 2013. http:/dx.doi.org/10.4136/ambiagua. 1116

DALTRO FILHO, J. Saneamento ambiental: doença, saúde e o saneamento da água. São Cristóvão: UFS, 2004. 332 p.

DOORENBOS, J.; PRUITT, J. O. Guidelines for predicting crop water requeriments. Rome: FAO, 1977. 179 p. (FAO Irrigation and Drainage, 24).

DUARTE, A. Reuso de água residuária tratada na irrigação da cultura do pimentão (Capsicum annun L). 2006. 187f. Tese (Doutorado) - Escola Superior de Agricultura Luiz de Queiroz, Piracicaba, 2006.

DUARTE, A. S.; AIROLDI, R. P. S.; FOLEGATTI, M. V.; BOTREL, T. A.; SOARES, T. M. Efeitos da aplicação de efluente tratado no solo: $\mathrm{pH}$, matéria orgânica, fósforo e potássio. Revista Brasileira de Engenharia Agrícola e Ambiental, v. 12, n. 3, p. 302-310, 2008. http://dx.doi.org/10.1590/S1415-43662008000300012

FARIA, M. A. Simpósio de manejo de irrigação. Poços de Caldas: [s.n.], 1998. 367 p.

HESPANHOL, I. Potencial de reuso de água no Brasil: agricultura, indústria, município e recarga de aquíferos. In: MANCUSO, P. C. S.; SANTOS, H. F. (Eds.). Reuso de água. Barueri: Manole, 2003. p. 37-95.

HESPANHOL, I. Potencial de reuso de água no Brasil: agricultura, indústria, municípios, recarga de aquíferos. Revista Brasileira de Recursos Hídricos - RBRH, Porto Alegre, ed. comemorativa, v. 7, n. 4, p. 75-97, dez. 2002. 
KING, A. D.; MAGNUSON, J. A.; TOROK, T.; COODMAN, N. Microbial flora and storage quality of partially processed lettuce. Journal of Food Science, v.56, p.459-461, 1991.

KORNACKI, J. L.; JOHNSON, J. L. Enterobacteriaceae, Coliforms, and Escherichia coli as quality and safety indicators. In: DOWNES, F. P.; ITO, K. Compendium of methods for the microbiological examination of foods. 4. ed. Washington: American Public Health Association, 2001. cap. 8, p. 69-82.

MEDEIROS, S. S.; SOARES, A. A.; FERREIRA, P. A.; NEVES, J. C. L.; SOUZA, J. A. Utilização de água residuária de origem doméstica na agricultura: estudo do estado nutricional do cafeeiro. Revista Brasileira de Engenharia Agrícola e Ambiental, v. 12, n. 2, p. 109-115, 2008. http://dx.doi.org/10.1590/S1415-43662008000200001

MORTON, D. R. Aerobic plate count. In: DOWNES, F. P.; ITO, K. Compendium of methods for the microbiological examination of foods. 4. ed. Washington: American Public Health Association, 2001. cap. 37, p. 63-67.

NGUYEN-THE, C.; CARLIN, F. The microbiology of minimally processed fresh fruits and vegetables. Critical Reviews in Food Science and nutrition, v. 34, p. 371-401, 1994.

PELCZAR JR., M. J; CHAN, E. C. S.; KRIEG, N. R. Microbiologia: conceitos e aplicações. 2. ed. São Paulo: McGraw-Hill, 1997. v. 2, cap. 30, p. 372-397.

RAMIRO, T. H. S.; BARBOSA JUNIOR, A. M.; DOLABELLA, S. S.; KATAGIRI, S.; MENDONÇA, L. C. Remoção de patógenos em sistema de lagoas de estabilização. In: ENCONTRO DE INICIAÇÃO CIENTÍFICA, 22., 2012, São Cristóvão. Anais... São Cristóvão: UFS, 2012.

SWANSON, K. M. J.; PETRAN, R. L.; HANLIN, J. H. Culture methods for enumeration of microorganisms. In: DOWNES, F. P.; ITO, K. (Eds.). Compedium of methods for the microbiological examination of foods. 4. ed. Washington: American Public Health Association, 2001. cap. 6, p. 53-62.

WORLD HEALTH ORGANIZATION - WHO. Wastewater use in agriculture. In:

Guidelines for the safe use of wastewater, excreta and greywater. Genebra, 2006. v. 2. 


Ambiente \& Água - An Interdisciplinary Journal of Applied Science
ISSN 1980-993X - doi:10.4136/1980-993X
www.ambi-agua.net
E-mail: ambi-agua@agro.unitau.br

\title{
Relação entre vazão e qualidade da água em uma seção de rio
}

\author{
doi: 10.4136/ambi-agua.1278
}

Received: 15 Jan. 2014; Accepted: 08 Mar. 2014

\author{
Luciano Vieira Barreto ${ }^{1}$; Micael de Souza Fraga ${ }^{2 *}$; Flávia Mariani Barros ${ }^{1}$; \\ Felizardo Adenilson Rocha ${ }^{3}$; Jhones da Silva Amorim ${ }^{1}$; \\ Stênio Rocha de Carvalho ${ }^{1}$; Paulo Bonomo ${ }^{1}$; Danilo Paulúcio da Silva ${ }^{1}$ \\ ${ }^{1}$ Universidade Estadual do Sudoeste da Bahia (UESB).- Itapetinga, BA, Brasil \\ ${ }^{2}$ Universidade Federal de Viçosa (UFV) - Viçosa, MG, Brasil \\ Departamento de Engenharia Agrícola \\ ${ }^{3}$ Instituto Federal da Bahia (IFBA) - Vitória da Conquista, BA, Brasil \\ *Autor correspondente: e-mail: micaelfraga@yahoo.com.br, \\ lucianoengenheiroambiental@yahoo.com.br, mariamariani@yahoo.com.br, \\ felizardoar@hotmail.com,jhones_sa@hotmail.com, steniophn@hotmail.com, \\ bonomopaulo@gmail.com, danilopaulucio@gmail.com
}

\section{RESUMO}

O objetivo do presente trabalho foi avaliar a dinâmica de determinadas variáveis de qualidade da água em função da vazão, em uma seção transversal do rio Catolé Grande próxima ao ponto de captação de água para abastecimento do município de Itapetinga-BA. Amostras de água foram coletadas por integração vertical, em diferentes meses, correspondente a diferentes vazões. Nessas amostras foram realizadas análises de potencial hidrogeniônico $(\mathrm{pH})$, turbidez, sólidos totais dissolvidos, salinidade e fósforo total. A velocidade do fluxo foi medida com o auxílio do molinete e a vazão foi calculada pelo produto da velocidade pela área da seção. Os resultados apontaram que a salinidade, os sólidos totais dissolvidos e a turbidez apresentaram comportamentos semelhantes, aumentando linearmente com o incremento da vazão, enquanto o pH apresentou tendência contrária. As concentrações de fósforo apresentaram comportamento exponencial em função da vazão, sendo que os valores médios desta variável ultrapassaram os limites estipulados pela resolução CONAMA 357 para a pior classe de qualidade de água doce.

Palavras-chave: monitoramento, poluição hídrica, hidrometria.

\section{Relationship between stream flow and water quality in a river section}

\section{ABSTRACT}

The objective of this study was to evaluate the dynamics of water quality variables in relation to the stream flow rate in a cross section of the Catolé Grande River near the point of water uptake to supply the city of Itapetinga-BA. Water samples were collected by vertical integration in different months, corresponding to different flow rates. This work analyzed the hydrogenionic potential $(\mathrm{pH})$, turbidity, total dissolved solids, salinity and total phosphorus of the water samples. The flow velocity was measured using a flow meter. The flow rate was calculated by the product of velocity by cross section area. The results showed that salinity, 
total dissolved solids and turbidity had similar behaviors in relation to the flow rate, with increased concentrations of these variables with increasing river flow rate, whereas the opposite was observed for $\mathrm{pH}$. Phosphorus concentrations showed an exponential behavior as a function of flow rate, and the average values of this variable exceeded the limits stipulated by CONAMA Resolution 357 for the worst class of freshwater quality.

Keywords: monitoring, water pollution, hydrometric.

\section{INTRODUÇÃO}

O crescimento populacional e as atividades humanas tem se despontado como um dos maiores responsáveis pela poluição do meio aquático. Os rios se tornaram ao longo dos anos depositários de rejeitos e resíduos de diversas formas: os esgotos domésticos e as águas residuárias provenientes de atividades pecuárias contribuem com elevadas cargas orgânicas; as indústrias com uma série de compostos sintéticos e elementos químicos potencialmente tóxicos e as atividades agrícolas com a contaminação por pesticidas e fertilizantes ricos em sais minerais (Fernandes Neto e Ferreira, 2007). Essas ações antrópicas podem afetar a qualidade do ambiente para os organismos aquáticos ou mesmo para a saúde humana.

O conhecimento do estado das águas permite auxiliar na definição de usos pretendidos, avaliar sua qualidade e indicar quais atividades humanas causam ou podem causar sua degradação (Haddad e Magalhães Júnior, 2010). Realizado de forma correta, o monitoramento qualitativo e quantitativo das águas pode indicar quais atividades humanas são potencialmente degradantes a este recurso, constituindo um dos instrumentos mais importantes no controle ambiental.

Conhecer a qualidade da água disponível é fundamental para a gestão dos recursos hídricos, este conhecimento pode ser representado por meio de diversas variáveis de qualidade as quais traduzem suas principais características. Assim, para realizar o controle da poluição das águas de rios e reservatórios, utilizam-se os padrões de qualidade, que definem os limites de concentração a que cada substância presente na água deve atender. Esses padrões dependem da classificação das águas interiores, que é estabelecida segundo seus usos preponderantes, conforme a Resolução do Conselho Nacional do Meio Ambiente (CONAMA) 357/05, variando da Classe especial até a Classe 4.

$\mathrm{O}$ uso de indicadores físico-químicos da qualidade da água consiste no emprego de variáveis que se correlacionam com as alterações ocorridas na bacia, sejam essas de origem antrópica ou natural. Deste modo, percebe-se que os cursos de água de uma bacia hidrográfica são afetados pelo uso e ocupação do solo e por contaminantes despejados nos recursos hídricos de toda a área de drenagem (Braga et al., 2005).

Portanto, o monitoramento dos corpos de água, tanto qualitativo quanto quantitativo, é de suma importância, principalmente para os que são utilizados como meio de abastecimento deste recurso para a população, pois, além de se evitar possíveis agravantes à saúde pública, podem-se promover planos ou projetos que visem à recuperação dos corpos de água já intensamente degradados pelas atividades antrópicas.

Diante do exposto, o presente estudo teve como objetivo verificar a influência de diferentes níveis de vazão no comportamento de variáveis de qualidade de água.

\section{MATERIAL E MÉTODOS}

O local do presente estudo esta situado na bacia hidrográfica do rio Catolé Grande, sendo esta pertencente à bacia do rio Pardo. Esta sub-bacia, considerando o sistema de projeção Universal Transversa de Mercator (UTM), está contida na zona 24, entre os paralelos N: 8380000 - 8226000 e meridianos E: 300000 - 385000, estando integralmente localizada na 
região sudoeste da Bahia. $\mathrm{O}$ rio Catolé nasce no planalto de Vitória da Conquista, próximo à cidade de Barra do Choça, dirigindo-se à calha do rio Pardo no sentido Nordeste-Sudeste, com seção de controle a jusante da cidade de Itapetinga-BA.

No que tange às atividades econômicas, as regiões de Itapetinga, Itambé e Caatiba, situadas no médio e baixo Catolé, são ocupadas pela atividade agropastoril extensiva. Já nas localidades de Vitória da Conquista e Barra do Choça, no alto Catolé, a atividade predominante é a produção de café.

A seção transversal do rio Catolé Grande estudada está localizada aproximadamente 50 metros a montante do ponto de coleta de água para abastecimento público do município de Itapetinga, apresentando, em média, largura de 28 metros (para o intervalo de vazões analisados neste estudo).

Para determinação da vazão foi calculada a área da seção transversal do rio a partir do somatório das subseções da seção. A velocidade do curso de água, em cada local de amostragem, foi determinada com o auxílio de um molinete hidrométrico modelo FP211, marca Global Water, e a área da seção transversal por meio de levantamento batimétrico local, segundo metodologia descrita por Pruski et al. (2006). A vazão do curso de água foi obtida pelo produto da velocidade média do escoamento pela área da seção transversal.

As posições horizontais e verticais do molinete para as determinações das velocidades médias foram definidas de acordo com a largura e profundidade do curso de água, conforme metodologia apresentada por Pruski et al. (2006).

Para o perfil transversal em estudo foram definidos três pontos de coleta de amostras de água: lado esquerdo do rio (e), centro do rio (c) e lado direito do rio (d), sendo a distância média dos pontos laterais às suas respectivas margens de $7 \mathrm{~m}$ e do ponto central às margens de $14 \mathrm{~m}$.

As coletas foram realizadas entre janeiro e novembro de 2011, totalizando oito coletas: no verão (07/01/2011 e 11/02/2011), outono (15/04/2011 e 14/05/2011), inverno (10/07/2011 e $20 / 08 / 2011)$ e na primavera $(02 / 10 / 2011$ e $05 / 11 / 2011)$.

As amostragens de água foram realizadas por integração vertical, com o auxilio de um amostrador de sedimentos em suspensão modelo US DH-48, sendo este amostrador aplicado a profundidades de até $2,7 \mathrm{~m}$ e baixas velocidades. As amostras foram acondicionadas em garrafas apropriadas e preservadas segundo metodologia descrita em APHA et al. (2005). Posteriormente foram transportadas diretamente para o Laboratório de Solos da Universidade Estadual do Sudoeste da Bahia, Campus Itapetinga, onde foram efetuadas as análises. Para cada data de amostragem foram realizadas três repetições em cada ponto.

A determinação da turbidez foi realizada pelo método nefolométrico, com o auxílio de um turbidímetro de bancada marca HANNA, modelo HI 93703. A salinidade, o pH e os sólidos totais dissolvidos foram medidos por meio de uma sonda multiparâmetro marca HANNA, modelo OX 9828. O fósforo total foi medido com o auxílio de um fotômetro de bancada, marca HANNA, modelo HI 83208. As análises realizadas por estes equipamentos foram baseadas em APHA et al. (2005).

A partir dos valores das concentrações de cada variável de qualidade de água considerada nesse estudo foram ajustados modelos para avaliação do comportamento dessas variáveis em função das vazões medidas.

Os modelos foram ajustados por meio de análise de regressão, sendo eles escolhidos com base na significância do coeficiente de regressão, no coeficiente de determinação e nas características do fenômeno em estudo. Além disso, também foi realizada a correlação de Pearson entre as variáveis de qualidade de água e a vazão em nível de significância de $1 \%$. Para as análises estatísticas, utilizou-se o software estatístico SAEGED. 


\section{RESULTADOS E DISCUSSÃO}

Os valores de profundidade média, velocidade da água e vazão na seção avaliada do rio Catolé Grande estão apresentados na Tabela 1.

Tabela 1. Valores de profundidade média, velocidade da água e vazão na seção avaliada do rio Catolé Grande em diferentes épocas de coleta.

\begin{tabular}{l|ccc}
\hline Data da coleta & $\begin{array}{c}\text { Profundidade média da seção } \\
(\mathrm{m})\end{array}$ & $\begin{array}{c}\text { Velocidade média } \\
\left(\mathrm{m} \mathrm{s}^{-1}\right)\end{array}$ & $\begin{array}{c}\text { Vazão } \\
\left(\mathrm{m}^{3} \mathrm{~s}^{-1}\right)\end{array}$ \\
\hline $07 / 01 / 2011$ & 1,47 & 0,33 & 8,17 \\
$11 / 02 / 2011$ & 1,52 & 0,15 & 6,47 \\
$15 / 04 / 2011$ & 1,49 & 0,19 & 7,97 \\
$14 / 05 / 2011$ & 1,47 & 0,20 & 8,29 \\
$10 / 07 / 2011$ & 1,40 & 016 & 6,58 \\
$20 / 08 / 2011$ & 1,40 & 0,14 & 5,08 \\
$22 / 10 / 2011$ & 1,41 & 0,13 & 5,58 \\
$05 / 11 / 2011$ & 1,40 & 0,10 & 3,98 \\
\hline
\end{tabular}

De acordo com os dados apresentados na Tabela 1 nota-se que a profundidade média da seção estudada variou entre 1,40 e 1,52 m, a velocidade da água foi menor na coleta realizada em novembro $\left(0,10 \mathrm{~m} \mathrm{~s}^{-1}\right)$, data também em que a vazão foi menor $\left(3,98 \mathrm{~m}^{3} \mathrm{~s}^{-1}\right)$, enquanto a maior velocidade foi verificada na coleta realizada no mês de janeiro $\left(0,33 \mathrm{~m} \mathrm{~s}^{-1}\right)$ cuja vazão foi de $8,17 \mathrm{~m}^{3} \mathrm{~s}^{-1}$.

A seguir são apresentados os comportamentos das variáveis de qualidade de água em função da vazão. Os modelos ajustados neste trabalho são válidos para o rio Catolé Grande, nas vazões entre $3,98 \mathrm{~m}^{3} \mathrm{~s}^{-1}$ e $8,29 \mathrm{~m}^{3} \mathrm{~s}^{-1}$.

\subsection{Potencial Hidrogeniônico (pH)}

$\mathrm{Na}$ Figura 1 estão apresentados os resultados do potencial hidrogeniônico, medidos e estimados por meio de equação ajustada em função das diferentes vazões no rio Catolé Grande.

Nota-se que, houve tendência da diminuição dos valores de $\mathrm{pH}$ com o aumento da vazão, contudo, a amplitude média dos valores observados foi pequena, entre 6,23 e 7,16, indicando valores aceitáveis segundo a Resolução CONAMA n. 357 (Brasil, 2005) a qual estipula valores de $\mathrm{pH}$ entre 6 e 9 para todas as classes de qualidade de água doce, ou seja, Classe 1, que pressupõe os usos mais nobres até a Classe 4 que pressupõe os usos menos nobres.

A pequena variação dos valores de $\mathrm{pH}$ pode estar relacionada ao fato de que o uso e a ocupação do solo na região está quase que estritamente restrito a atividade agropecuária. Segundo Derísio (2000) maiores alterações referentes aos valores de $\mathrm{pH}$ são provocadas por despejos industriais, os quais no ponto de coleta em estudo não são observados.

Nota-se que, houve tendência da diminuição dos valores de $\mathrm{pH}$ com o aumento da vazão, contudo, a amplitude média dos valores observados foi pequena, entre 6,23 e 7,16, indicando valores aceitáveis segundo a Resolução CONAMA n. 357 (Brasil, 2005) a qual estipula valores de $\mathrm{pH}$ entre 6 e 9 para todas as classes de qualidade de água doce, ou seja, Classe 1, que pressupõe os usos mais nobres até a Classe 4 que pressupõe os usos menos nobres. 


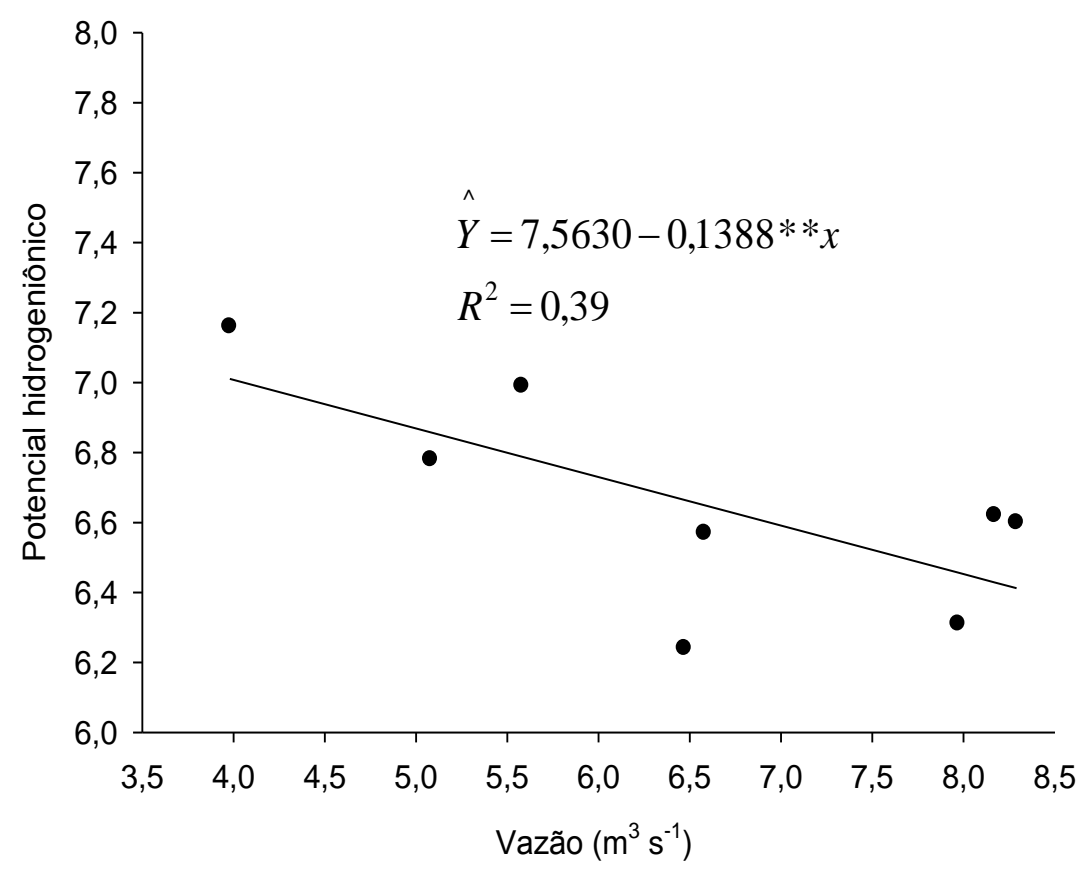

Figura 1. Valores médios observados e estimados do potencial hidrogeniônico $(\mathrm{pH})$ em função da vazão na seção transversal estudada do rio Catolé Grande. (**significativo a $1 \%$ pelo teste $\mathrm{t}$ ).

A pequena variação dos valores de $\mathrm{pH}$ pode estar relacionada ao fato de que o uso e a ocupação do solo na região está quase que estritamente restrito a atividade agropecuária. Segundo Derísio (2000) maiores alterações referentes aos valores de $\mathrm{pH}$ são provocadas por despejos industriais, os quais no ponto de coleta em estudo não são observados.

Considerando todos os meses em estudo, nota-se que houve correlação negativa entre o pH e a vazão, - 0,62 (probabilidade de erro, $\mathrm{P}<0,01$ ), ou seja, há tendência de diminuição do $\mathrm{pH}$ com o aumento da vazão, assim como verificado na Figura 1. Vários autores (Alvarenga et al., 2012; Queiroz et al., 2013; Carvalho e Siqueira, 2010, entre outros) estudando outros cursos de água também verificaram a mesma tendência, porém todos corroboram com o fato de que é difícil estabelecer uma explicação imediata para o comportamento do $\mathrm{pH}$ apenas em função da vazão pois este é influenciado por inúmeros fatores, tais como sólidos, gases dissolvidos, dureza, alcalinidade, temperatura, fatores bióticos entre outros (Fritzons et al., 2003).

\subsection{Salinidade}

Na Figura 2 estão apresentados os resultados da salinidade observados e estimados por meio de equação ajustada em função da vazão no rio Catolé Grande. Todos os valores médios da salinidade se enquadraram abaixo do limite estabelecido pela Resolução CONAMA 357 de 2005, que fixa valores para salinidade até $0,5 \%$ para rios de Classe 2.

De acordo com a equação ajustada, houve tendência de aumento da concentração desta variável com o aumento da vazão, contudo a amplitude dos valores da salinidade foram baixas, variando de 0,04 a $0,08 \mathrm{ppm}$. Houve correlação positiva entre a salinidade e a vazão quando observado todo o período em estudo, 0,87 ( $<<0,01)$. Isso demonstra alta influência entre o aumento da vazão a concentração de sais nas águas do rio Catolé Grande. 


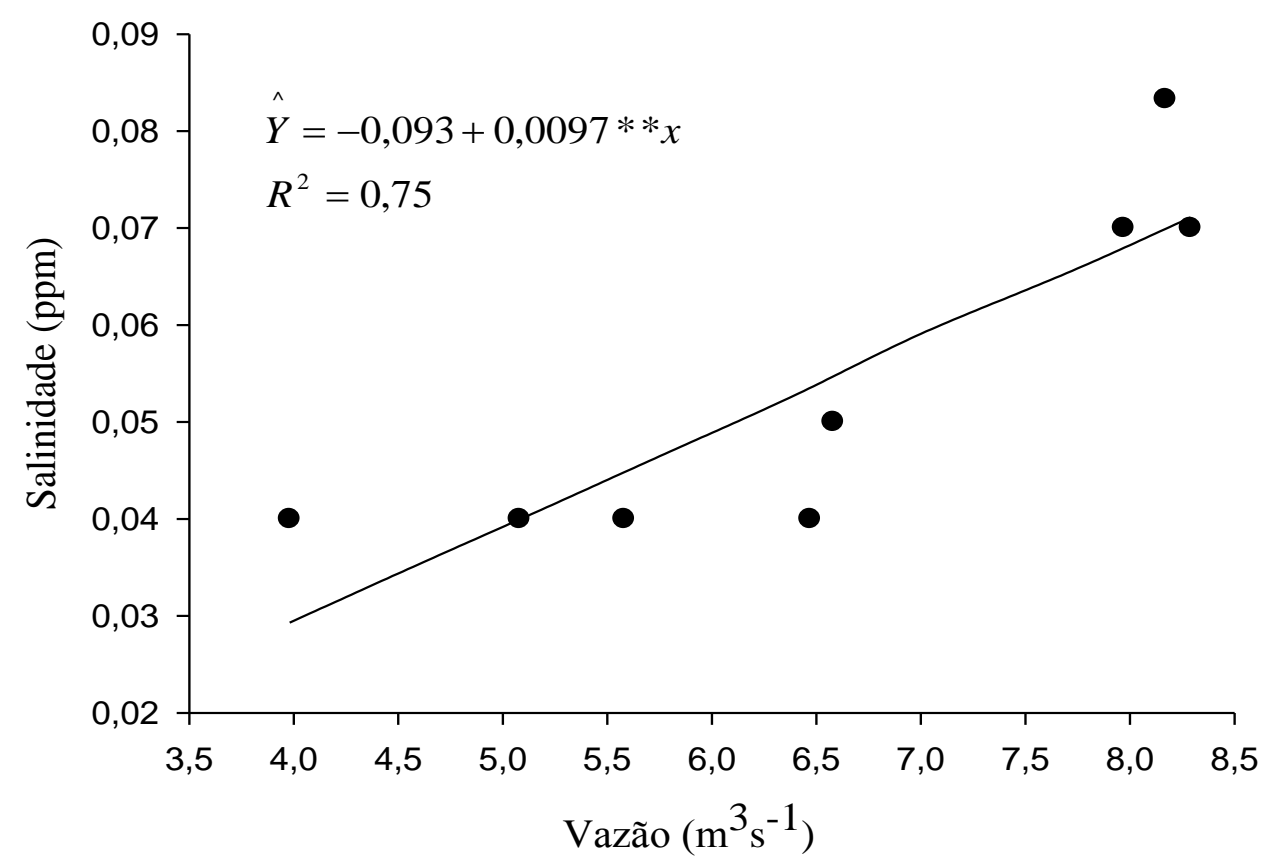

Figura 2. Valores médios observados e estimados da concentração da salinidade em função da vazão na seção transversal estudada do rio Catolé Grande. $(* *$ significativo a $1 \%$ pelo teste $\mathrm{t})$.

Barreto et al. (2009) monitoraram o comportamento da salinidade do rio Catolé Grande em uma seção próximo à captação de água do SAAE entre julho de 2008 a março de 2009. Os autores encontraram valores, em média, de $0,03 \mathrm{ppm}$ para salinidade nos nove meses de coleta, corroborando com os resultados obtidos no presente estudo que apontam que a seção avaliada do rio possui baixa salinidade.

Oliveira et al. (2010) analisaram a bacia hidrográfica do rio Salitre, extremo norte da Bahia, entre os meses de maio a outubro de 2009, em 21 pontos de coleta de dados. Os autores destacaram que somente em quatro locais próximos às nascentes, os valores de salinidade permaneceram próximos ao limite estabelecido pela legislação em vigor; em dois pontos de coleta perto de áreas com formações calcárias a salinidade foi de 0,66 e 0,59 ppm, respectivamente. Os demais locais apresentaram maiores alterações das concentrações da salinidade, variando entre 0,96 a 2,8 ppm (água salobra). Os autores mencionaram que estas alterações das concentrações da salinidade sofreram influência de fatores como a geologia local e trechos que possuem contribuições de aquíferos calcários ou cristalinos que tendem a aumentar esta salinidade, o que não é o caso do rio Catolé Grande.

\subsection{Turbidez}

$\mathrm{Na}$ Figura 3 são apresentados os resultados da turbidez, observados e estimados por meio de equação ajustada em função das diferentes vazões no rio Catolé Grande, nos diferentes meses avaliados no ano de 2011.

Observa-se que a turbidez apresentou menor valor, 5,45 UNT, quando foi registrada a menor vazão $\left(3,98 \mathrm{~m}^{3} \mathrm{~s}^{-1}\right)$, ocorrendo também tendência do aumento da turbidez com o aumento da vazão. De acordo com os resultados obtidos, verificou-se que todas as amostras encontraram-se dentro dos padrões de qualidade de água estabelecidos na Resolução CONAMA n. ${ }^{\circ}$ 357/05, onde o valor de turbidez para rios de Classe 2, não deve exceder 100 UNT. 


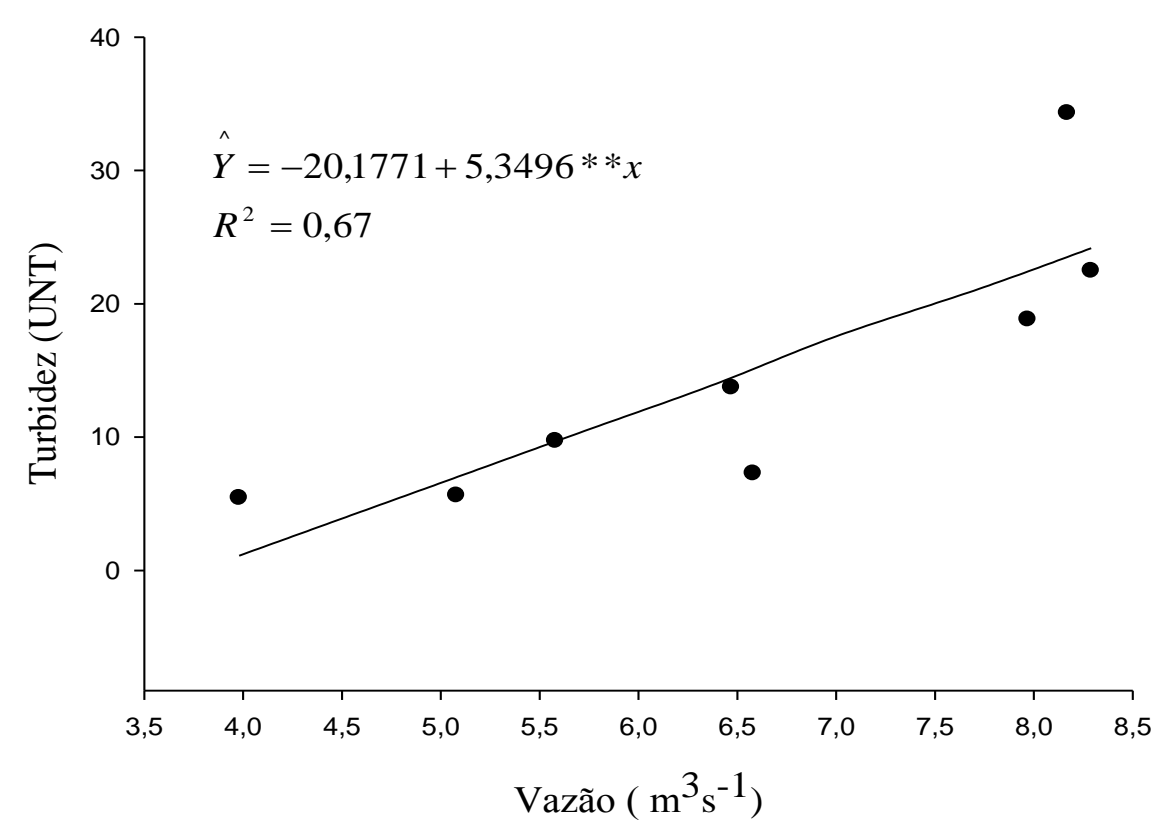

Figura 3. Valores médios observados e estimados da turbidez em função da vazão na seção transversal estudada do rio Catolé Grande, BA. $(* *$ significativo a $1 \%$ pelo teste $\mathrm{t})$.

Ficou constatada correlação positiva entre a turbidez e a vazão: $0,81(\mathrm{P}<0,01)$, para todo o período em estudo. Desta forma, o aumento da vazão influenciou diretamente no aumento da turbidez. Segundo Santos et al. (2013), tal comportamento pode ser explicado devido ao fato de que durante as cheias, partículas de solo são carreadas para os rios, principalmente nessa bacia, em que a cobertura vegetal em sua grande parte é constituída de pastagens degradadas.

A turbidez utilizada isoladamente não é um parâmetro confiável para efeitos de contaminação, ela deve ser utilizada com outras análises que garantam maior confiabilidade aos resultados. É importante ressaltar que somente a turbidez, em sua origem natural, não traz inconvenientes sanitários diretos, porém pode reduzir a penetração da luz, prejudicando a fotossíntese (Imhoff, 1996).

Rocha et al. (2010) analisaram este mesmo ponto de coleta com amostragem de 0-20 cm de profundidade por integração vertical e constataram modificações nos valores de turbidez para os diferentes meses avaliados, variando aproximadamente entre 5 e 25 UNT. Os autores concluíram que esse fato pode ser atribuído às precipitações ocorridas, que contribuíram para o aumento desta variável, alocando assim ao rio maiores concentrações de partículas.

Barros et al. (2011) estudaram a variação da turbidez neste mesmo rio, no período compreendido entre maio e agosto de 2011. Os autores observaram que a turbidez variou com mais intensidade apenas na margem esquerda do rio, local de remanso onde existe presença significativa de plantas aquáticas, de grande quantidade de matéria orgânica e de sólidos em suspensão, quando comparado aos outros pontos de coleta.

Moura et al. (2009) verificaram no rio Cascavel, oeste do Paraná, que a turbidez apresentou resultados elevados no verão, chegando ao maior valor de 106,57 UNT, quando o índice pluviométrico foi maior, o que ocasionou revolvimento e transporte dos sedimentos presente no fundo do rio. 


\subsection{Sólidos totais dissolvidos (STD)}

$\mathrm{Na}$ Figura 4 são apresentados os resultados dos sólidos totais dissolvidos observados e estimados por meio de equação ajustada em função das diferentes vazões no rio Catolé Grande, nos meses avaliados no ano de 2011.

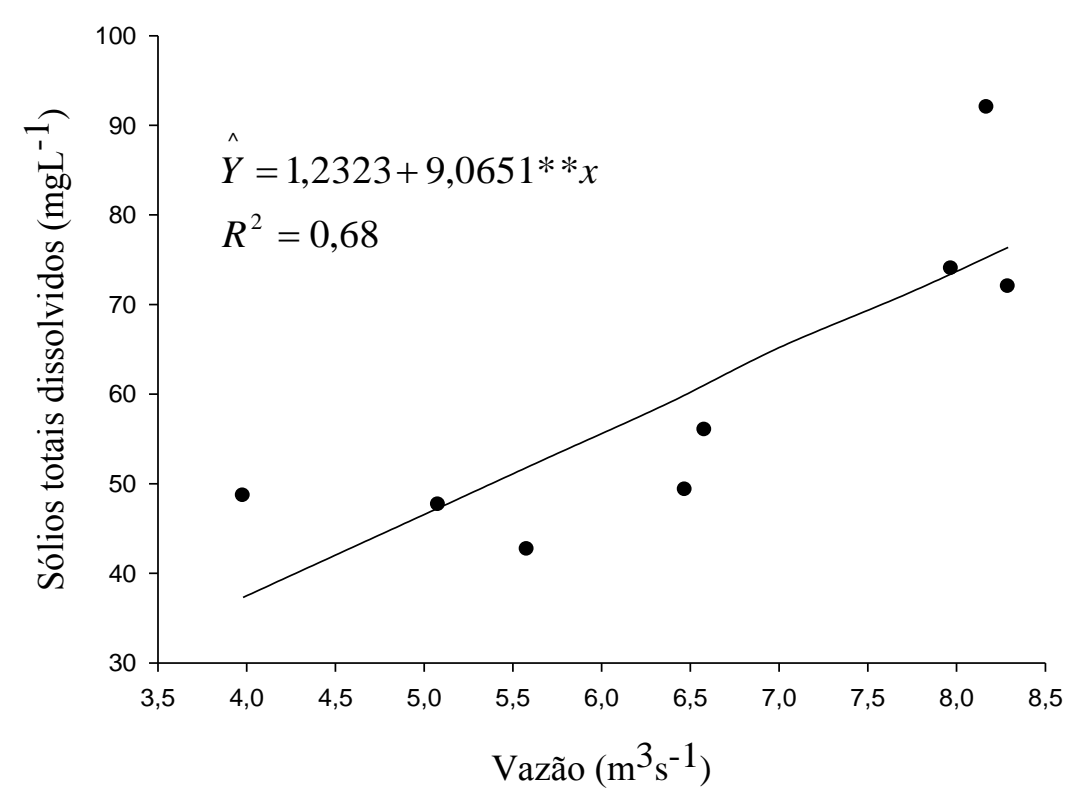

Figura 4. Valores médios observados e estimados dos sólidos totais dissolvidos em função da vazão na seção transversal estudada do rio Catolé Grande, BA. (**significativo a 1\% pelo teste t).

Na Figura 4 pode-se observar o comportamento crescente na concentração dos STD com o aumento da vazão, semelhante ao que foi encontrado para a salinidade.

Os valores de sólidos totais dissolvidos variaram entre 42,66 e $92 \mathrm{mg} \mathrm{L}^{-1}$, muito abaixo do limite estabelecido pela Resolução CONAMA n. ${ }^{\circ} 357$, de 2005, a qual limita a concentração desta variável em $500 \mathrm{mg} \mathrm{L}^{-1}$ para rios de Classe 1 a 4 . Considerando todos os meses em estudo, houve correlação positiva entre o STD e a vazão de 0,82 ( $\mathrm{P}<0,01)$.

Generoso et al. (2010) analisaram a quantidade de sólidos dissolvidos presentes na água do mesmo rio em estudo, em diferentes épocas e pontos distintos da seção transversal e verificaram que esta variável não apresentou grande variação entre os diferentes períodos avaliados, divergindo do presente estudo, que demonstra correlação positiva entre as duas variáveis.

Segundo Carvalho e Oliveira (2003), os sólidos dissolvidos na água indicam a presença de sais, ácidos minerais e outros contaminantes que se despejados no curso hídrico podem aumentar a demanda química e bioquímica de oxigênio nas águas, levando à depleção do oxigênio dissolvido no meio. Além disso, os sólidos totais dissolvidos podem demonstrar a carga de poluentes lançadas no curso de água.

Zanini et al. (2010) estudaram as águas da microbacia do córrego Rico em JaboticabalSP, entre setembro de 2007 e agosto de 2008, sendo realizadas coletas quinzenalmente em três pontos distintos. Os autores concluíram que os sólidos totais dissolvidos não apresentaram variação entre os pontos de montante à jusante e sim entre os períodos, destacando aumento no período de chuvas, corroborando assim com os resultados do presente estudo o qual constata maiores valores de sólidos totais dissolvidos em maiores níveis de vazão. 


\section{5..Fósforo total}

Na Figura 5 são apresentados os resultados do fósforo total observados e estimados por meio de equação ajustada em função das diferentes vazões no rio Catolé Grande, nos meses avaliados no ano de 2011.

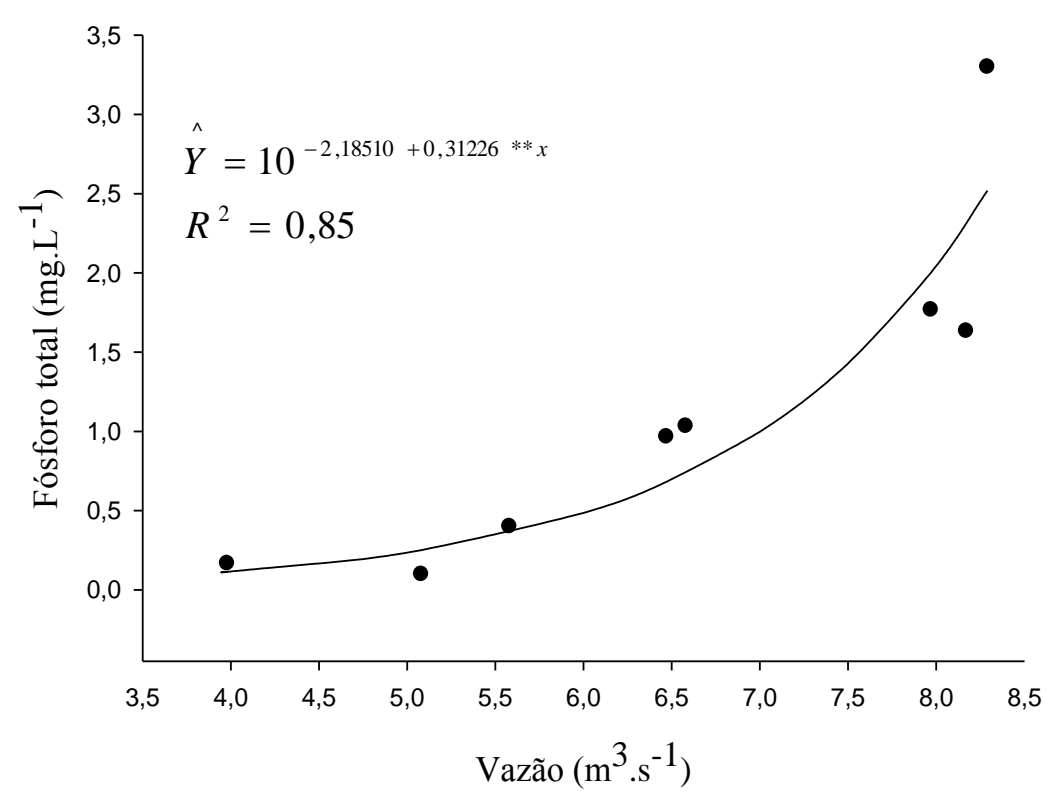

Figura 5. Valores médios observados e estimados do fósforo total em função da vazão na seção transversal estudada do rio Catolé Grande. (**significativo a 1\% pelo teste t).

De acordo com a figura verifica-se que o fósforo apresentou comportamento exponencial em função da vazão, sendo observada pequena variação crescente no valor desta variável até aproximadamente $6 \mathrm{~m}^{3} \mathrm{~s}^{-1}$, a partir desta vazão a concentração de fósforo total apresentou crescimento mais significativo. Este fato provavelmente ocorreu devido ao revolvimento do sedimento no leito do rio em função do aumento da vazão, deslocando o fósforo total decantado, influenciando assim no aumento da concentração desta variável na coluna de água. Segundo Koskivahala e Hartikainen (2001) e McDowell et al. (2001) em ambientes lóticos a dessorção do fósforo é facilitada pela ressuspensão dos sedimentos e pela turbulência da água.

Considerando todos os meses avaliados houve correlação positiva entre o fósforo total e a vazão, sendo esta de 0,62 ( $<<0,01)$. Fia (2009) relata uma das causas do aumento da quantidade de fósforo total na água também pode ser devido a grande retirada deste nutriente do solo em épocas de chuva, o qual escoa para os corpos de água, sendo esta situação mais agravada em áreas agrícolas (Cunha et al., 2013).

Observando a média do período em estudo, a concentração do fósforo total foi de $1,17 \mathrm{mg} \mathrm{L}^{-1}$. Merece destaque a concentração média da coleta realizada no mês $\mathrm{d}$ maio, $3,3 \mathrm{mg} \mathrm{L}^{-1}$. Esses valores indicam que esta variável ficou acima dos valores estabelecidos pela resolução CONAMA 357/05 em relação a pior classe de qualidade de água (Classe 4).

\section{CONCLUSÃO}

Tendo por base os resultados obtidos e ponderando as condições em que o estudo foi realizado, conclui-se que:

A salinidade, a turbidez e os sólidos totais dissolvidos apresentaram correlações positivas em função das vazões analisadas, sendo observado comportamento linear crescente na 
concentração das variáveis com o aumento da vazão, em contrapartida os valores de $\mathrm{pH}$ apresentaram tendência de decréscimo com o aumento da vazão.

A concentração de fósforo total apresentou comportamento exponencial positivo em função da vazão, sendo a provável causa desse comportamento o revolvimento de sedimentos do leito do rio.

Os valores de $\mathrm{pH}$ estão dentro da faixa de valores para águas de Classes 1 a 4 estabelecidos pela resolução CONAMA (6 a 9), assim como as concentrações de sólidos totais dissolvidos se situam muito abaixo do limite máximo para estas classes $\left(500 \mathrm{mg} \mathrm{L}^{-1}\right)$, ao contrário, os valores médios de fósforo total, estão acima do estabelecido para águas doces Classe 4.

\section{REFERÊNCIAS}

AlVARENGA, L. A.; MARTINS, M. P. P; CUARTAS, L. A.; PENTEAdO, V. A.; ANDRADE A. Estudo da qualidade e quantidade da água em microbacia, afluente do rio Paraíba do Sul - São Paulo, após ações de preservação ambiental. Revista Ambiente \& Água, Taubaté, v. 7, n. 3, 2012. http://dx.doi.org/10.4136/ambi.agua.987

AMERICAN PUBLICA HEALTH ASSOCIATION - APHA; AMERICAN WATER WORKS ASSOCIATION - AWWA; WATER ENVIRONMENT FEDERATION WEF. Standard methods for the examination of water and wastewater. Washington, DC, 2005.

BARRETO, L. V.; ROCHA, F. A.; OLIVEIRA, M. S. C. Monitoramento da qualidade da água na microbacia hidrográfica do rio Catolé, em Itapetinga-BA. Enciclopédia Biosfera, Goiânia, v. 5, n. 8, 2009.

BARROS, F. M.; ROCHA, F. A.; FRAGA, M. S.; GENEROSO, T. N.; MELO, A. R. B. Variação da turbidez em pontos distintos de um perfil transversal do rio Catolé-BA, sob diferentes níveis de vazão. Enciclopédia Biosfera, Goiânia, v. 7, n. 12, 2011.

BRAGA, B.; HESPANHOL, I.; CONEJO, J. G. L.; MIERZWA, J. C.; BARROS, M. T. L.; SPENCER, M. et al. Introdução à engenharia ambiental. São Paulo: Prentice Hall, 2005.

BRASIL. Ministério do Meio Ambiente. Conselho Nacional do Meio Ambiente - CONAMA. Resolução no 357 de 17 de março de 2005. Disponível em: <http://www.mma.gov.br /port/conama/res/res05/res35705.pdf > . Acesso em: 22 de agosto de 2011.

CARvalho, R. A; Oliveira, M. C. V. Princípios Básicos de Saneamento do Meio. São

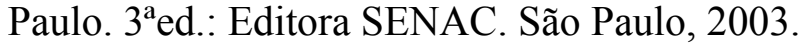

CARVALHO, G. L.; SIQUEIRA, E. Q. Qualidade da água do rio Meia Ponte no perímetro urbano do município de Goiânia-Goiás. Revista Eletrônica de Engenharia Civil, Goiás, v. 1, n. 1, 2010.

CUNHA, R. W.; GARCIA JUNIOR, M. D. N.; ALBERTONI, E. F.; PALMA-SILVA, C. Qualidade de água de uma lagoa rasa em meio rural no sul do Brasil. Revista Brasileira de Engenharia Agrícola e Ambiental, Campina Grande, v. 17, n. 7, 2013. http://dx.doi.org/10.1590/S1415-43662013000700012

DERISIO, J. C. Introdução ao controle da poluição ambiental. São Paulo: Signus, 2000. 
FIA, R.; MATOS, A. T.; CORADI, P. C.; PEREIRA-RAMIREZ, O. Estado trófico da água na bacia hidrográfica da Lagoa Mirim, RS, Brasil. Revista Ambiente \& Água, Taubaté, v. 4, n. 1, 2009. http://dx.doi.org/10.4136/ambi.agua.78

FRITZSONS, E.; HINDI, E. C.; MANTOVANI, L. E.RIZZI, N. E. As alterações da qualidade da água do rio Capivari com o deflúvio: um instrumento de diagnóstico de qualidade ambiental. Engenharia Sanitária e Ambiental, Rio de Janeiro, v. 8, n. 4, 2003.

GENEROSO, T. N.; FRAGA, M. S.; BARROS, F. M.; TAGLIAFERRI, C.; ROSA, R. C. C. Influência do local de amostragem nos valores de variáveis de qualidade de água em uma seção transversal do rio Catolé-BA. Enciclopédia Biosfera, Goiânia, v. 6, n. 11, 2010

HADDAD, E. A.; MAGALHAES JUNIOR, A. P. Influência antrópica na qualidade da água da bacia hidrográfica do rio são Miguel, Carste do alto São Francisco, Minas Gerais. Geosul, Florianópolis, v. 25, n. 49, 2010.

IMHOFF, K. R. Manual de tratamento de águas residuárias. Tradução de Max Lothar Hess. São Paulo: Edgard Blucher, 1996.

KOSKI-VAHALA, J.; HARTIKAINEN, H. Assessment of the risk of phosphorus loading due to resuspended sediment. Journal of Environmental Quality, Madison, v. 30, p. 960-966, 2001. http://dx.doi.org/10.2134/jeq2001.303960x

McDOWELL, R. W.; SHARPLEY, A. N.; CONDRON, L. M.; HAYGORTH, P. M.; BROOKES, P. C. Processes controlling soil phosphorus release to runoff and implications for agricultural management. Nutrient Cycling in Agroecosystems, v. 59, p. 269-284, 2001. http://dx.doi.org/10.1023/A:1014419206761

MOURA, A. C.; ASSUMPÇÃO, R. A. B.; BUSCHOFF, J. Monitoramento físico-químico e microbiológico da água do rio cascavel durante o período de 2003 a 2006. Arquivos do Instituto Biológico, São Paulo, v. 76, n. 1, 2009.

NETO, M. L. F.; FERREIRA, A. P. Perspectivas da Sustentabilidade Ambiental Diante da Contaminação Química da Água: Desafios Normativos. Revista de Gestão Integrada em Saúde do Trabalho e Meio Ambiente, v. 2, n. 4, 2007.

PRUSKI, F. F.; SILVA, D. D. da; KOETZ, M. Estudo de vazão em cursos d'água. Viçosa: AEAGRI, 2006. 151 p. (Caderno Didático, 43)

QUEIROZ M. M. F.; DANTAS, E. F.; SILVA, A. L. Qualidade e quantidade da água do rio Piancó, tributário do rio Piranhas Açu na região nordeste. Revista Verde de Agroecologia e Desenvolvimento Sustentável, v. 8, n. 2, 2013.

ROCHA, F. A.; OLIVEIRA, M. S. C.; MELO, A. R. B.; BARROS, F. M.; BARRETO, L. V. Variáveis de qualidade de água influenciadas pelo tipo e época de amostragem, no rio Catolé-BA. Enciclopédia Biosfera, Goiânia, v. 6, n. 11, 2010.

SANTOS, Q. R; FRAGA, M. S.; ULIANA, E. M; REIS, A. S; BARROS, F. M. Monitoramento da qualidade da água em uma seção transversal do rio Catolé, Itapetinga-BA. Enciclopédia Biosfera, Goiânia, v.9, n.16, 2013. 
ZANINI, H. L. H. T.; AMARAL, L. A.; ZANINI, J. R.; TAVARES, L. H. S. Caracterização da água da microbacia do córrego Rico avaliada pelo índice de qualidade de água e de estado trófico. Engenharia Agrícola, Jaboticabal, v. 30, n. 4, 2010. http://dx.doi.org/10.1590/S0100-69162010000400017 


Ambiente \& Água - An Interdisciplinary Journal of Applied Science
ISSN 1980-993X - doi:10.4136/1980-993X
www.ambi-agua.net
E-mail: ambi-agua@agro.unitau.br

\title{
Índices de Qualidade da Água e de Estado Trófico na Represa Dr. João Penido (Juiz de Fora, MG)
}

\author{
doi: 10.4136/ambi-agua.1290
}

Received: 28 Jan. 2014; Accepted: 27 Feb. 2014

\author{
Magaly H. S. Bucci; Luiz Fernando C. de Oliveira* \\ Universidade Federal de Juiz de Fora (UFJF) - Juiz de Fora, MG, Brasil \\ *Autor correspondente: e-mail: luiz.oliveira@ufjf.edu.br, \\ magalybucci@gmail.com
}

\section{RESUMO}

A represa Dr. João Penido contém o reservatório que é a principal fonte de abastecimento de água potável da cidade de Juiz de Fora, localizada na região sudeste do Brasil. Sua construção se deu em 1934 e desde então, vem sofrendo com o mau uso e ocupação das terras em seu entorno. O objetivo geral deste estudo foi caracterizar a qualidade hídrica do manancial, relacionando os resultados com o uso e ocupação do solo da bacia hidrográfica. Para isto foram realizadas análises físico-químicas e microbiológicas de amostras de água referente aos seguintes parâmetros: temperatura da água, oxigênio dissolvido, $\mathrm{pH}$, turbidez, sólidos totais, demanda bioquímica de oxigênio, nitrato, fósforo total, clorofila $a$ e coliformes termotolerantes. Os resultados obtidos foram comparados com a Resolução 357/2005 do Conselho Nacional de Meio Ambiente (CONAMA) e aqueles que apresentaram desconformidade com a norma foram: oxigênio dissolvido, $\mathrm{pH}$, turbidez, fósforo total e demanda bioquímica de oxigênio. Foi calculado o Índice de Qualidade da Água (IQA) e o Índice de Estado Trófico (IET) para as amostras analisadas. Os resultados mostraram a predominância do estado "mesotrófico" e nível "médio" de qualidade da água, indicando que as formas de uso e ocupação do solo da bacia hidrográfica têm produzido impactos negativos no ecossistema aquático. O monitoramento demonstrou ser ferramenta fundamental, proporcionando subsídios para a elaboração de um plano de gestão integrada nas ações que envolvem a preservação e recuperação da qualidade do manancial.

Palavras-chave: estado trófico, manancial, monitoramento, plano de gestão integrada, qualidade da água.

\section{Water Quality and Trophic State indices at the Dr. João Penido Dam (Juiz de Fora, MG, Brazil)}

\section{ABSTRACT}

The Dr. João Penido Dam contains the reservoir that is the main source of drinking water for the city of Juiz de Fora, located in the southeastern region of Brazil. It was built in in 1934 and has since suffered from the misuse and occupation of the land that surrounds it. This study sought to characterize the reservoir's water quality and to correlate our results with land use. Accordingly, we performed physical-chemical and microbiological analyses of water samples in order to measure the following parameters: water temperature, dissolved oxygen, 
$\mathrm{pH}$, turbidity, total solids, biochemical oxygen demand, nitrate, total phosphorus, chlorophyll $a$ and thermo-tolerant coliform. The results were compared with Resolution 357/2005 of the National Environmental Council (CONAMA), and it was found that the dissolved oxygen, $\mathrm{pH}$, turbity, total phosphorus and biochemical oxygen demand were not in conformity. We also calculated the Water Quality Index (WQI) and Trophic State Index (TSI) for the all of the samples and found the water to be in a predominately "mesothrophic" state and the water quality level to be "medium." This suggests that occupation and the forms of use of the watershed have negatively impacted the aquatic ecosystem. Monitoring has proven itself to be a critical tool, providing subsidies for the development of an integrated management plan for the preservation and restoration of the quality of the reservoir.

Keywords: trophic state, water source, monitoring, integrated management plan, water quality index.

\section{INTRODUÇÃO}

O constante crescimento da demanda de água implica na necessidade de aumentar a disponibilidade deste recurso para atender os seus múltiplos usos. Como consequência, a construção de barragens para diversas finalidades representa o progresso. Em contraposição, acarreta uma série de impactos nos ecossistemas naturais decorrentes da transformação de ambientes lóticos em lênticos, provocando alterações no comportamento natural e na qualidade hídrica dos rios e córregos represados (Von Sperling, 1999), sendo uma interferência antropogênica de grande impacto ecológico nos ecossistemas. Pimenta et al. (2012) citam que alguns exemplos destas alterações são: diminuição do fluxo de água, aumento da taxa de sedimentação, aumento do tempo de residência da água, estratificação térmica e diminuição das concentrações de oxigênio dissolvido, dentre outros.

Embora o uso mais nobre que se possa dar a um recurso hídrico seja o consumo humano, os mananciais brasileiros têm apresentado progressiva degradação da qualidade de suas águas (Carneiro et al., 2005). Contribuem para isso o lançamento inadequado de efluentes (sanitários e industriais), o uso de fertilizantes, agrotóxicos e pesticidas em áreas agrícolas (Carmo et al., 2005; Carvalho et al., 2000; Dores e De-Lamonica-Freire, 2001), além do mau uso e ocupação das terras, dentre outras. Além disso, os múltiplos usos de reservatórios no Brasil, aliado às atividades humanas tem acelerado também o processo de eutrofização dos corpos hídricos (Soares et al., 2008). Desta forma, a preocupação com a degradação destes ambientes aquáticos tem crescido no meio científico, sendo necessário incrementar os estudos e ampliar os conhecimentos sobre o assunto.

Outra questão relevante é que existe uma carência de informações a respeito de pequenas bacias hidrográficas, como é o caso da bacia da represa Dr. João Penido, situada do município de Juiz de Fora (Minas Gerais). Não há estudos sistematizados sobre a qualidade das águas do manancial, sendo que o mesmo era desconhecido para a comunidade científica até a realização desta pesquisa.

O reservatório foi construído em 1934 e desde então, vem sofrendo processos de degradação, apesar de estar protegido por leis municipais, estaduais e federais. Este fato pode ser evidenciado pelas ocupações irregulares às margens dos corpos d'água, erosões, ausência de mata ciliar, assoreamento, bem como a proliferação de macrófitas aquáticas em vários pontos do manancial, principalmente nas regiões de entrada dos tributários, indicando possível estado de eutrofização. Este fato vem causando grande preocupação, uma vez que o manancial é responsável por $65 \%$ do abastecimento público de água potável da cidade (Juiz de Fora, 2004).

Tendo em vista a sua importância e o cenário atual em que se encontra, este trabalho foi estruturado apresentando como objetivo principal a caracterização da qualidade hídrica do manancial, relacionando os resultados com o uso e ocupação do solo da bacia hidrográfica. 
Para isso foram delineados três objetivos específicos: (1) realização de análises físicoquímicas e microbiológicas de amostras de água; (2) comparação dos resultados obtidos com os limites definidos pela Resolução 357/2005 do Conselho Nacional de Meio Ambiente (CONAMA) (Brasil, 2005), utilizando como referência "águas doces classe 1"; (3) cálculo do Índice de Qualidade da Água (IQA) e do Índice de Estado Trófico (IET) mensal para as águas da represa e de dois principais tributários.

Pode-se avaliar a qualidade hídrica de um reservatório utilizando-se o Índice de Qualidade da Água (IQA). Seu cálculo é baseado em nove parâmetros (descritos em material e métodos), que possuem pesos diferenciados de acordo com sua importância relativa no cálculo do índice. Estes parâmetros representam os indicadores de qualidade da água e foram estabelecidos pela National Sanitation Foudantion nos Estados Unidos, para o desenvolvimento de um índice que demostrasse a qualidade da água. O IQA reflete a interferência por esgotos sanitários e outros materiais orgânicos, nutrientes e sólidos presentes na água (Minas Gerais, 2005).

Outra forma de investigação é pelos Índices de Estado Trófico, que foram desenvolvidos para avaliar a qualidade da água quanto ao enriquecimento por nutrientes e seu efeito relacionado ao crescimento excessivo de algas ou macrófitas, facilitando a classificação de corpos d'água em diferentes graus de trofia. Eles podem auxiliar nas decisões sobre riscos de ocorrer florações de algas, bem como no controle da eutrofização (aumento na concentração de nutrientes na água, especialmente fósforo e nitrogênio), que tem sido uma preocupação mundial para os tomadores de decisões referentes ao gerenciamento de recursos hídricos (Brito et al., 2011; Cunha et al., 2013; Liu et al., 2014).

Vários países do mundo vêm enfrentando o desafio da eutrofização acelerada e a degradação dos ambientes aquáticos provocados principalmente pelas interferências humanas. Nos reservatórios brasileiros o problema tem aumentado, tornando os ambientes mais vulneráveis, afetando o balanço ecológico (Rangel et al., 2012), e comprometendo a qualidade das águas no país (Brito et al., 2011).

Com base nos conhecimentos científicos adquiridos e aqui apresentados, poderá ser elaborado um plano de gerenciamento integrado para a preservação dos recursos hídricos da região, além de proporcionar estudos comparativos para reservatórios de abastecimento de água no Brasil e no mundo.

\section{MATERIAL E MÉTODOS}

\section{1.Área de estudo}

Juiz de Fora se localiza no estado de Minas Gerais, na região sudeste do Brasil. O município está inserido na Bacia Hidrográfica do Rio Paraíba do Sul, uma das mais populosas do país. O clima da região, de acordo com a classificação de Köppen, é do tipo Cwa, ou seja, mesotérmico com verões quentes e úmidos. O município está enquadrado na região fitoecológica denominada Floresta Estacional Semidecidual (formação do Bioma Mata Atlântica), típica de climas com duas estações bem definidas (Juiz de Fora, 2004).

Os córregos estudados, denominados córrego Grama e ribeirão dos Burros, bem como a represa Dr. João Penido estão contidos na sub-bacia (SB) do ribeirão dos Burros, pertencente à bacia do rio Paraibuna (Juiz de Fora, 2004). De acordo com a Deliberação Normativa 16/1996 do Conselho Estadual de Política Ambiental (COPAM) (Minas Gerais, 1996), que dispõe sobre o enquadramento dos corpos d'água da bacia do rio Paraibuna, as águas desta SB no trecho estudado, são classe 1.

A área da bacia hidrográfica da represa é de $68 \mathrm{~km}^{2}$. Trata-se de um sistema raso, com profundidade média de 6,53 metros e máxima, de 10,90 metros, cuja área superficial é 370 hectares (valores aproximados) (CESAMA, 2010). A vazão regularizada do reservatório é 
$750 \mathrm{~L} / \mathrm{s}$ e o volume de água armazenada é aproximadamente $14.094 .000 \mathrm{~m}^{3}$ (dado de 1985) (Leme Engenharia S. A., 1985). Atualmente, este volume é bem menor, em função das consequências advindas do próprio represamento, como proliferação de plantas aquáticas, diminuição da vazão dos cursos d'água e os processos de sedimentação que o reservatório vem sofrendo, desde que foi construído. Esta situação é mais evidente na região de entrada dos tributários. As características de degradação citadas para a represa também fazem parte da realidade dos afluentes. A ausência de mata ciliar e áreas florestadas, além do mau uso e ocupação das terras da região são outras características importantes que devem ser consideradas para os ambientes estudados.

Foram definidos cinco pontos de coleta, sendo dois nos tributários citados, e três na represa, cuja localização pode ser visualizada na Figura 1. Os pontos de amostragem dos afluentes localizam-se à montante de sua foz na represa.

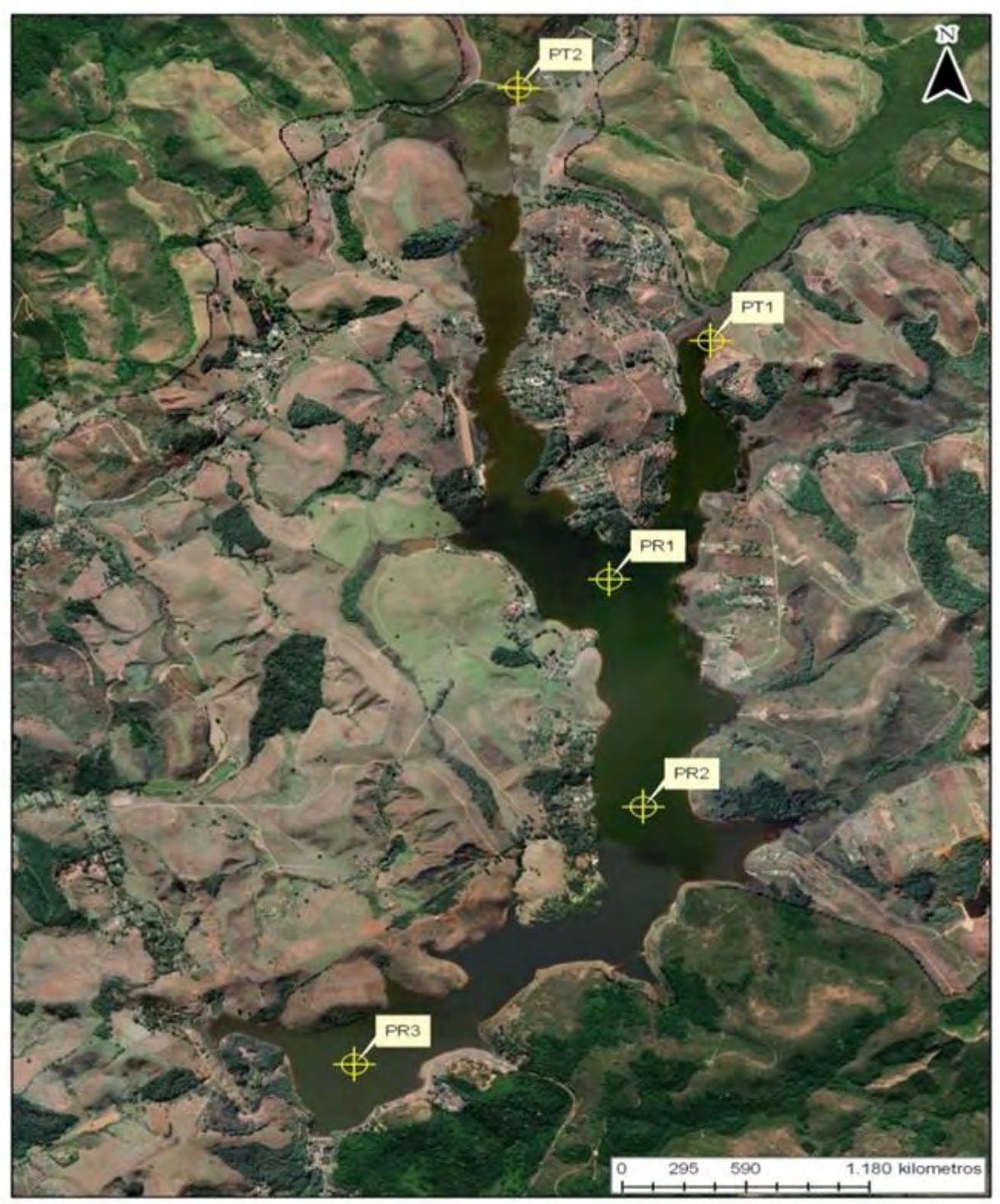

Figura 1. Ortofoto do vôo aerofotogramétrico, datada de 2007, indicando os pontos de coleta em tributários e represa: PT1: córrego Grama; PT2: ribeirão dos Burros; PR1: Ponto 1 da represa (zona fluvial); PR2: Ponto 2 da represa (zona intermediária); PR3: Ponto 3 da represa (zona lacustre).

Fonte: Juiz de Fora (2007). 
A localização, altitude e profundidade média dos pontos de coleta estão apresentados na Tabela 1.

Tabela 1. Localização, altitude e profundidade média dos pontos de coleta.

\begin{tabular}{c|cccc}
\hline Ponto & \multicolumn{2}{|c}{ Coordenadas geográficas UTM } & $\begin{array}{c}\text { Altitude } \\
(\mathrm{m})\end{array}$ & $\begin{array}{c}\text { Profundidade média } \\
(\mathrm{m})\end{array}$ \\
\hline PT1 & $21^{\circ} 38^{\prime} 29,8^{\prime \prime} \mathrm{S}$ & $43^{\circ} 23^{\prime} 09,1^{\prime \prime} \mathrm{W}$ & 754,0 & 0,97 \\
PT2 & $21^{\circ} 37^{\prime} 40,9^{\prime \prime} \mathrm{S}$ & $43^{\circ} 23^{\prime} 43,2^{\prime \prime} \mathrm{W}$ & 752,8 & 0,97 \\
PR1 & $21^{\circ} 39^{\prime} 25,6^{\prime \prime} \mathrm{S}$ & $43^{\circ} 23^{\prime} 24,3^{\prime \prime} \mathrm{W}$ & 752,7 & 5,39 \\
PR2 & $21^{\circ} 40^{\prime} 17,9^{\prime \prime} \mathrm{S}$ & $43^{\circ} 23^{\prime} 23,7^{\prime \prime} \mathrm{W}$ & 751,9 & 6,71 \\
PR3 & $21^{\circ} 40^{\prime} 51,8^{\prime \prime} \mathrm{S}$ & $43^{\circ} 24^{\prime} 07,5^{\prime \prime} \mathrm{W}$ & 745,5 & 8,87 \\
\hline
\end{tabular}

\subsection{Metodologia}

Foram realizadas campanhas mensais durante um ano (período de julho/ 2009 a junho/2010). As técnicas de coleta e amostragem seguiram a NBR 9898 da Associação Brasileira de Normas e Técnicas (ABNT) (ABNT, 1987). As amostras foram coletadas aproximadamente a $10 \mathrm{~cm}$ da superfície, em frascos de polietileno de $500 \mathrm{~mL}$, previamente ambientados com a água do local por três vezes. Em seguida, foram preservadas em isopor com gelo (temperatura em torno de $4^{\circ} \mathrm{C}$ ) até a chegada aos laboratórios.

Os parâmetros analisados foram: temperatura da água, oxigênio dissolvido (OD), pH (medidos in situ com auxílio de equipamentos portáteis), turbidez, sólidos totais, demanda bioquímica de oxigênio (DBO), nitrato $\left(\mathrm{NO}_{3}{ }^{-}\right)$, fósforo total (PT), clorofila $a$ e coliformes termotolerantes. Os respectivos métodos de ensaio seguiram o preconizado no Standard Methods for the Examination of Water and Wastewater (APHA, 1998).

O IET foi calculado no período de julho/ 2009 a junho/ 2010, de acordo com a metodologia proposta por Lamparelli (2004), que foi uma adaptação para ambientes tropicais do índice adotado por Carlson (1977), utilizado para climas temperados. Esse método também é utilizado pela Companhia de Saneamento do Estado de São Paulo (CETESB) na rede de monitoramento do referido estado. As Equações de cálculo estão apresentadas a seguir:

Ambientes lóticos (córregos/rios): Equações 1 e 2

$$
\begin{aligned}
& \operatorname{IET}(\mathrm{CL})=10 \times\left(6-\left\{\frac{-0,7-0,6 \times \ln [\mathrm{CL}]}{\ln 2}\right\}\right)-20 \\
& \operatorname{IET}(\mathrm{PT})=10 \times\left(6-\left\{\frac{0,42-0,36 \times \ln [\mathrm{PT}]}{\ln 2}\right\}\right)-20
\end{aligned}
$$

Ambientes lênticos (reservatórios): Equações 3 e 4

$$
\operatorname{IET}(\mathrm{CL})=10 \times\left(6-\left\{\frac{0,92-0,34 \times \ln [\mathrm{CL}]}{\ln 2}\right\}\right)
$$




$$
\operatorname{IET}(\mathrm{PT})=10 \times\left(6-\left\{\frac{1,77-0,42 \times \ln [\mathrm{PT}]}{\ln 2}\right\}\right)
$$

em que:

PT: concentração de fósforo total em $\mu \mathrm{g} / \mathrm{L} ; \mathrm{CL}$ : concentração de clorofila $a \mathrm{em} \mu \mathrm{g} / \mathrm{L} ; \ln$ : logaritmo natural.

O resultado final do IET corresponde à média aritmética simples dos índices relativos ao fósforo total e a clorofila $a$, conforme Equação 5:

$$
\mathrm{IET}=\frac{\mathrm{IET}(\mathrm{CL})+\mathrm{IET}(\mathrm{PT})}{2}
$$

As Equações 1, 2 e 5 foram utilizadas para os pontos dos córregos (PT1 e PT2) e as Equações 3, 4 e 5, para os pontos da represa (PR1, PR2 e PR3).

Os limites dos diferentes níveis tróficos para rios e reservatórios são: ultraoligotrófico (IET $\leq 47)$; oligotrófico $(47<$ IET $\leq 52)$; mesotrófico $(52<$ IET $\leq 59)$; eutrófico $(59<$ IET $\leq 63)$; supereutrófico $(63<$ IET $\leq 67)$; hipereutrófico (IET > 67) (Lamparelli, 2004).

IQA foi calculado no período de dezembro/ 2009 a junho/ 2010, de acordo com a metodologia utilizada pelo Instituto Mineiro de Gestão das Águas (IGAM), no Projeto "Águas de Minas", referente ao monitoramento das águas superficiais do estado de Minas Gerais. O IQA corresponde a um número que varia de 0 a 100, cujo cálculo é baseado em nove parâmetros, com pesos diferenciados: $\mathrm{OD}$, coliformes termotolerantes, $\mathrm{pH}, \mathrm{NO}_{3}^{-}, \mathrm{PT}$, DBO, temperatura da água, turbidez e sólidos totais. O IQA é calculado pelo produtório ponderado das qualidades de água correspondentes aos nove parâmetros, conforme Equação 6, de acordo com a fórmula (Minas Gerais, 2005):

$$
I Q A=\prod_{i=1}^{9} q_{i}^{{ }^{w_{i}}}
$$

em que:

IQA = Índice de Qualidade de Água;

$\mathrm{q}_{\mathrm{i}}=$ qualidade do parâmetro i obtido pela curva média específica de qualidade;

$\mathrm{W}_{\mathrm{i}}=$ peso atribuído ao parâmetro, em função de sua importância na qualidade, entre 0 e 1 .

As equações obtidas para o Sistema de Cálculo de Qualidade da Água, bem como as curvas médias de qualidade dos nove parâmetros individuais estão apresentadas em Minas Gerais (2005).

Os níveis de qualidade da água e suas respectivas faixas são: excelente $(90<\mathrm{IQA} \leq 100)$; bom $(70<\mathrm{IQA} \leq 90)$; médio $(50<\mathrm{IQA} \leq 70)$; ruim $(25<\mathrm{IQA} \leq 50)$; muito ruim $(0 \leq \mathrm{IQA} \leq 25)$ (Minas Gerais, 2005). 


\section{RESULTADOS E DISCUSSÃO}

Os resultados dos parâmetros, a estatística descritiva dos mesmos, bem como os limites definidos pela Resolução CONAMA 357/2005 para corpos d'água classe 1, estão apresentados na Tabela 2.

Tabela 2. Resultados obtidos e estatística descritiva dos parâmetros analisados para os pontos amostrados em tributários e represa, incluindo os limites definidos pelo CONAMA para "águas doces classe 1".

\begin{tabular}{|c|c|c|c|c|c|c|c|}
\hline \multirow{2}{*}{ Parâmetro } & \multirow{2}{*}{ Resultado } & \multicolumn{2}{|c|}{ Pontos dos tributários } & \multicolumn{3}{|c|}{ Pontos da represa } & \multirow{2}{*}{$\begin{array}{c}\text { Limites } \\
\text { CONAMA } \\
\text { 357/2005 }\end{array}$} \\
\hline & & PT1 & PT2 & PR1 & PR2 & PR3 & \\
\hline \multirow{3}{*}{$\mathrm{T}\left({ }^{\circ} \mathrm{C}\right)$} & $\mathrm{M} \pm \mathrm{DP}$ & $22,73 \pm 4,31$ & $21,92 \pm 4,53$ & $24,03 \pm 3,48$ & $24,23 \pm 3,34$ & $24,15 \pm 3,34$ & \multirow{3}{*}{ - } \\
\hline & Máx. & 34,00 & 30,30 & 31,60 & 31,40 & 30,30 & \\
\hline & Mín. & 17,00 & 16,00 & 19,20 & 19,80 & 18,50 & \\
\hline \multirow{3}{*}{$\begin{array}{c}\mathrm{OD}\left(\mathrm{mg} \cdot \mathrm{L}^{-}\right. \\
\left.{ }^{\prime}\right)\end{array}$} & $\mathrm{M} \pm \mathrm{DP}$ & $5,81 \pm 1,40$ & $5,19 \pm 1,46$ & $6,35 \pm 0,71$ & $6,32 \pm 0,85$ & $6,52 \pm 1,09$ & \multirow{3}{*}{$\begin{array}{l}>6,0 \\
\mathrm{mg} \cdot \mathrm{L}^{-1}\end{array}$} \\
\hline & Máx. & 7,50 & 7,90 & 7,50 & 7,50 & 8,40 & \\
\hline & Mín. & 4,00 & 3,00 & 5,10 & 5,10 & 5,10 & \\
\hline \multirow{3}{*}{$\mathrm{pH}$} & $\mathrm{M} \pm \mathrm{DP}$ & $6,38 \pm 0,58$ & $5,95 \pm 0,64$ & $6,73 \pm 0,70$ & $6,79 \pm 0,67$ & $6,82 \pm 0,77$ & \multirow{3}{*}{$\begin{array}{c}\text { Entre } 6,0 \mathrm{e} \\
9,0\end{array}$} \\
\hline & Máx. & 7,60 & 7,30 & 8,00 & 7,70 & 7,60 & \\
\hline & Mín. & 5,00 & 5,00 & 5,60 & 5,70 & 5,20 & \\
\hline \multirow{3}{*}{$\begin{array}{l}\text { Turbidez } \\
\text { (UNT) }\end{array}$} & $\mathrm{M} \pm \mathrm{DP}$ & $26,64 \pm 32,65$ & $52,70 \pm 51,52$ & $20,64 \pm 14,32$ & $\begin{array}{c}18,34 \pm 17,01 \\
17,01\end{array}$ & $17,74 \pm 16,33$ & \multirow{3}{*}{$40,0 \mathrm{UNT}$} \\
\hline & Máx. & 115,00 & 126,70 & 40,60 & 41,80 & 40,80 & \\
\hline & Mín. & 1,00 & 2,26 & 2,96 & 1,00 & 1,00 & \\
\hline \multirow{3}{*}{$\begin{array}{l}\text { Sólidos } \\
\text { totais } \\
\left(\mathrm{mg} \cdot \mathrm{L}^{-1}\right)\end{array}$} & $\mathrm{M} \pm \mathrm{DP}$ & $32,29 \pm 45,44$ & $36,86 \pm 63,23$ & $37,86 \pm 36,35$ & $25,43 \pm 24,42$ & $41,57 \pm 52,28$ & \multirow{3}{*}{$\begin{array}{l}500,0 \\
\mathrm{mg} \cdot \mathrm{L}^{-1}\end{array}$} \\
\hline & Máx. & 135,00 & 180,00 & 120,00 & 80,00 & 160,00 & \\
\hline & Mín. & 10,00 & 10,00 & 20,00 & 10,00 & 19,00 & \\
\hline \multirow{3}{*}{$\begin{array}{c}\mathrm{DBO} \\
\left(\mathrm{mg} \cdot \mathrm{L}^{-1}\right)\end{array}$} & $\mathrm{M} \pm \mathrm{DP}$ & $11,47 \pm 3,55$ & $8,87 \pm 3,17$ & $10,76 \pm 2,06$ & $6,90 \pm 3,56$ & $9,83 \pm 2,74$ & \multirow{3}{*}{$3,0 \mathrm{mg} \cdot \mathrm{L}^{-1}$} \\
\hline & Máx. & 16,21 & 14,73 & 13,67 & 14,50 & 13,50 & \\
\hline & Mín. & 5,71 & 4,11 & 7,60 & 2,70 & 4,32 & \\
\hline \multirow{3}{*}{$\begin{array}{l}\text { Nitrato } \\
\left(\mathrm{mg} \cdot \mathrm{L}^{-1}\right)\end{array}$} & $\mathrm{M} \pm \mathrm{DP}$ & $0,554 \pm 0,261$ & $0,442 \pm 0,382$ & $0,561 \pm 0,360$ & $0,486 \pm 0,323$ & $0,467 \pm 0,294$ & \multirow{3}{*}{$10,0 \mathrm{mg} \cdot \mathrm{L}^{-1}$} \\
\hline & Máx. & 0,919 & 1,143 & 1,015 & 0,906 & 0,859 & \\
\hline & Mín. & 0,222 & 0,059 & 0,126 & 0,190 & 0,194 & \\
\hline \multirow{3}{*}{$\underset{\left(\mathrm{mg} \cdot \mathrm{L}^{-1}\right)}{\mathrm{PT}}$} & $\mathrm{M} \pm \mathrm{DP}$ & $0,082 \pm 0,129$ & $0,074 \pm 0,126$ & $0,066 \pm 0,114$ & $0,066 \pm 0,100$ & $0,068 \pm 0,116$ & \multirow{3}{*}{$*$} \\
\hline & Máx. & 0,470 & 0,460 & 0,420 & 0,360 & 0,420 & \\
\hline & Mín. & 0,009 & 0,013 & 0,007 & 0,006 & 0,004 & \\
\hline \multirow{3}{*}{$\begin{array}{l}\text { Clorofila } a \\
\left(\mu \mathrm{g} . \mathrm{L}^{-1}\right)\end{array}$} & $\mathrm{M} \pm \mathrm{DP}$ & $2,53 \pm 0,68$ & $1,71 \pm 0,79$ & $3,35 \pm 0,88$ & $3,14 \pm 0,87$ & $3,18 \pm 0,55$ & \multirow{3}{*}{$10 \mu \mathrm{g} \cdot \mathrm{L}^{-1}$} \\
\hline & Máx. & 3,75 & 2,85 & 5,00 & 4,85 & 4,05 & \\
\hline & Mín. & 1,75 & 0,30 & 2,35 & 2,05 & 2,35 & \\
\hline
\end{tabular}

Nota: *Ambiente lêntico: 0,020 mg. $\mathrm{L}^{-1}$; tributários diretos de ambientes lênticos: 0,025 mg. $\mathrm{L}^{-1}$.

Média \pm M \pm DP = Média \pm Desvio Padrão; Máx. = valor máximo; Mín. = valor mínimo. 
O parâmetro coliformes termotolerantes foi determinado em Número Mais Provável por $100 \mathrm{ml}$ (NMP/100 mL). O método utilizado (APHA, 1998; Silva et al., 2005) não permitiu a quantificação exata na maioria das análises laboratoriais realizadas, mas observou-se que sua presença na água é baixa. Por este motivo, não foi apresentada estatística descritiva dos mesmos. Os resultados estão apresentados na Tabela 3.

Tabela 3. Resultados de coliformes termotolerantes (NMP/100 mL) em águas de tributários e represa.

\begin{tabular}{c|cc|ccc}
\hline \multirow{2}{*}{ Mês } & \multicolumn{2}{|c|}{ Pontos dos tributários } & \multicolumn{3}{c}{ Pontos da represa } \\
\cline { 2 - 6 } & PT1 & PT2 & PR1 & PR2 & PR3 \\
\hline dez/09 & $<3$ & $<3$ & $<3$ & $<3$ & $<3$ \\
jan/10 & $<3$ & $<3$ & $<3$ & $<3$ & $<3$ \\
fev/10 & $<3$ & $<3$ & $<3$ & $<3$ & $<3$ \\
mar/10 & $<3$ & $<3$ & $<3$ & $<3$ & $<3$ \\
abr/10 & $<3$ & $<3$ & $<3$ & $<3$ & $<3$ \\
mai/10 & $<3$ & $<3$ & $<3$ & $<3$ & $<3$ \\
jun/10 & $<3$ & 4 & $<3$ & $<3$ & 4 \\
\hline
\end{tabular}

As porcentagens de resultados em desacordo com a Resolução CONAMA 357/2005 estão apresentadas na figura 2. Os demais parâmetros, quando contemplados por esta norma estiveram de acordo com os limites estabelecidos.

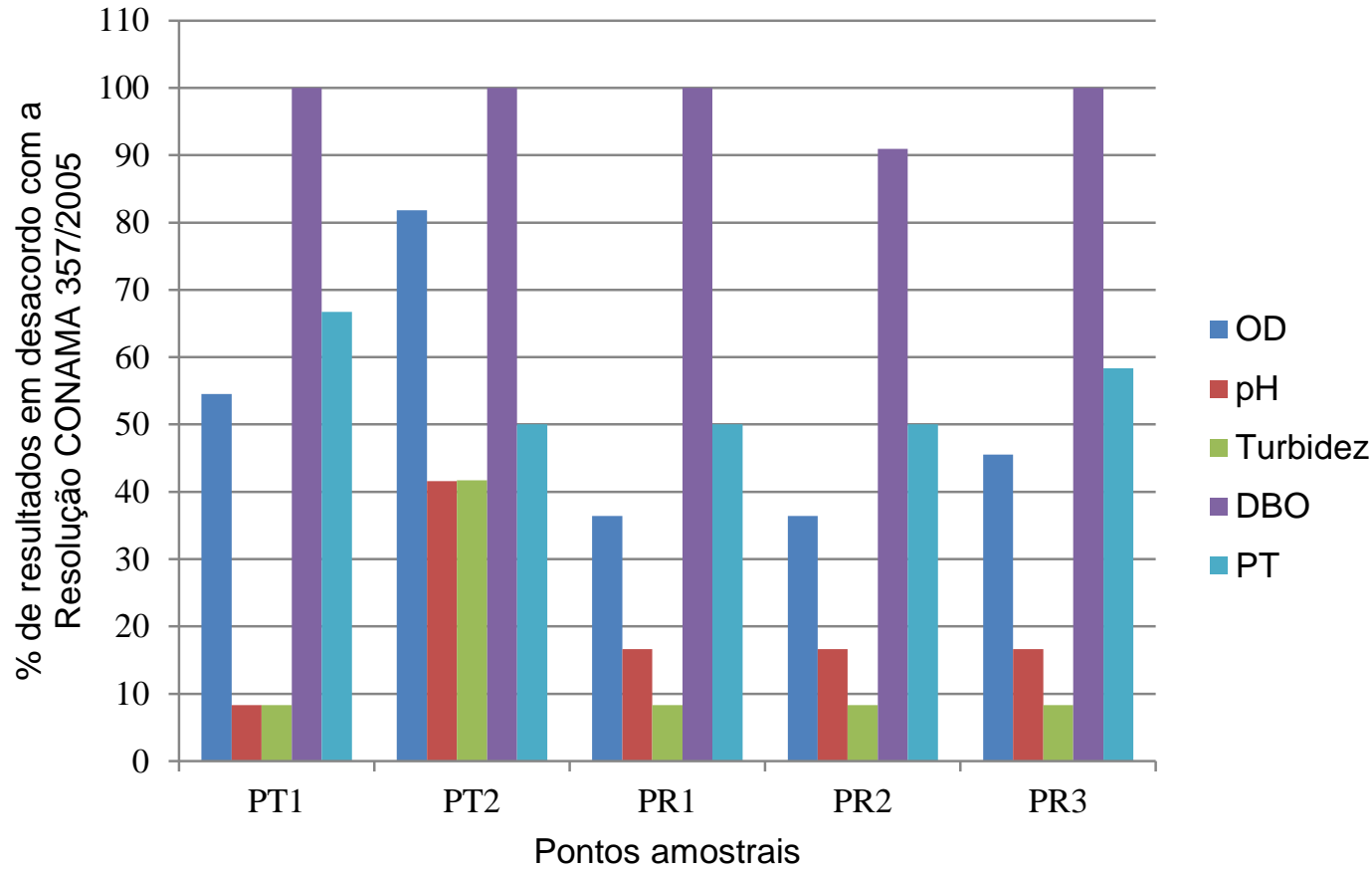

Figura 2. Porcentagens de resultados dos parâmetros analisados em desconformidade com os limites definidos pela Resolução CONAMA 357/2005 nos pontos amostrais estudados. 


\subsection{Tratamento estatístico dos dados de IQA e IET}

O teste estatístico aplicado para os resultados dos dois pontos nos córregos (PT1 e PT2) foi o teste t de Student, que compara somente duas médias. A análise de variância ANOVA é uma extensão do teste t de Student (Vieira, 2006) e foi utilizada para os pontos da represa (PR1, PR2 e PR3), pois permite a comparação de qualquer número de médias. A ideia é comparar a variação da eficiência entre tratamentos ao longo do tempo de operação, por meio de um teste estatístico, associado aos graus de liberdade, a um nível de significância de 5\%. As análises estatísticas foram realizadas com o auxílio do software Primer of Biostatistics versão 4.0 (Stanton, 1997).

\subsection{Resultados dos parâmetros individuais}

\subsection{Oxigênio dissolvido (OD)}

A represa apresentou melhores índices de OD que os afluentes, fato também observado na rede de monitoramento das águas superficiais do estado de São Paulo (Lamparelli, 2004).

As menores médias obtidas nos pontos dos tributários podem indicar entradas de carga orgânica provenientes de efluentes domésticos e/ou escoamento superficial da bacia de drenagem. Acredita-se também que as macrófitas interferem nesses resultados, pois são abundantes nessas regiões. Essas plantas fornecem oxigênio para o meio aquático, porém, após completarem seu ciclo de vida entram em processo de decomposição, passando a ser consumidoras de OD da massa líquida. Além disso, elas constituem barreiras físicas e podem aumentar a resistência à livre movimentação de água e ar, bem como diminuir a ação dos ventos sobre o espelho d'água. As macrófitas também possibilitam maior retenção de material orgânico transportado de locais à montante da bacia hidrográfica, que ao ser degradado pelos microrganismos aeróbios, proporcionam consumo de OD. A proliferação de plantas aquáticas é consequência do incremento de nutrientes no meio, bem como de interferências antrópicas que começam a surgir a partir do próprio represamento.

A menor média de todos os pontos e a maior porcentagem de resultados em desconformidade com a Resolução CONAMA 357/2005 ocorreram no ribeirão dos Burros (PT2). Para este afluente, além do OD que teve 75,0 \% do total de resultados em desacordo, outros parâmetros também não atenderam a referida norma, como: PT $(50,0 \%)$, pH $(41,6 \%)$, turbidez $(41,6 \%)$ e DBO $(100,0 \%)$. Isso indica grande impacto neste ambiente, proporcionado pelo mau uso e ocupação das terras em seu entorno. Uma das justificativas está na rede de esgotos clandestina construída pelos moradores do local, direcionando os efluentes domésticos para o ribeirão, à montante do ponto de coleta (PT2). As reações de degradação da matéria orgânica presente nestes resíduos consomem OD do meio. Os resultados mostram a interferência antrópica provocando deterioração do ecossistema aquático, que fica mais vulnerável devido à ausência de mata ciliar.

As concentrações mínimas observadas no reservatório ocorreram no período de estiagem (maio a julho/2010) devido a menor diluição de matéria orgânica e outras substâncias na água. Nos afluentes, as mínimas ocorreram em mês de cheia (dezembro/2009) devido ao escoamento superficial da bacia de drenagem, mostrando que os córregos são mais vulneráveis ao impacto das águas pluviais.

\subsection{Potencial Hidrogeniônico (pH)}

Normalmente o $\mathrm{pH}$ de águas doces é mantido em torno da neutralidade, pelo sistema de tamponamento baseado nas concentrações de carbonato e bicarbonato em solução provenientes do $\mathrm{CO}_{2}$. As florações de algas ou macrófitas no ambiente interferem nesse sistema tampão, podendo-se observar aumento de acidez ou alcalinidade da água. Se há aumento da fotossíntese, o $\mathrm{pH}$ tende a aumentar, pois há consumo de $\mathrm{CO}_{2}$ no processo. Porém, os íons carbonato ou bicarbonato existentes no meio o tampona, mantendo o $\mathrm{pH}$ em 
torno de 6,5. Por outro lado, os organismos heterotróficos tendem a baixar o $\mathrm{pH}$ da massa líquida por meio dos processos metabólicos de respiração e decomposição, que liberam $\mathrm{CO}_{2}$ no meio (Fernandes et al., 2005). Estes últimos processos também contribuem com o incremento de outras substâncias no ambiente, como os ácidos húmicos e fúlvicos (CETESB, 2010).

$\mathrm{Na}$ análise dos resultados, observou-se que a variação sazonal foi bastante significativa. No período de estiagem, todas as medições estiveram em conformidade com os limites definidos pelo CONAMA.

A intensa pluviosidade ocorrida em dezembro/2009 $(315,6 \mathrm{~mm})$ registrada pela Estação Pluviométrica da Represa Dr. João Penido (EPRJP), provocou stress nos ambientes. Entre dezembro/ 2009 e abril/ 2010 (cheia), o ribeirão dos Burros (PT2) apresentou pH em desconformidade em todas as medições, sendo obtidos valores que variaram de 5,0 a 5,9. Águas de chuva podem interferir no $\mathrm{pH}$ dos ecossistemas aquáticos continentais, pois normalmente são ácidas, com pH entre 5,0 e 6,0 (Esteves, 1998). O efeito é mais acentuado, quando os ambientes possuem baixa capacidade de tamponamento e isso foi observado para este ribeirão no referido período, onde todas as amostras estiveram em desconformidade, retornando ao equilíbrio somente em maio/2010. Este ponto de coleta localiza-se entre as plantas e provavelmente isso está interferindo no sistema tampão do ecossistema aquático. Os efeitos são potencializados pela disposição inadequada de esgotos no córrego. Observou-se que a represa e o córrego Grama (PT1) demonstraram melhor capacidade de recuperação do equilíbrio iônico do sistema, após o stress provocado pelo aumento da pluviosidade.

A menor média obtida e a maior porcentagem de medições referentes ao $\mathrm{pH}$ em desacordo com o CONAMA foram obtidas para o ribeirão dos Burros (PT2) pelos motivos já explanados. Para o reservatório, a menor média foi obtida no PR1 por sofrer forte influência das águas tributárias.

\subsection{Turbidez}

As médias relativas a este parâmetro foram maiores nos tributários, se comparadas ao reservatório, fato também constatado na rede de monitoramento do estado de São Paulo (Lamparelli, 2004).

As maiores médias, bem como a maior porcentagem de resultados de turbidez em desacordo com o CONAMA foram obtidas no ribeirão dos Burros (PT2), justificado pelas características lóticas deste ambiente, abundância de plantas aquáticas e pela presença de esgotos no córrego. Foi feita uma observação referente à interferência antrópica neste ribeirão, nas coletas de dezembro/ 2009 e janeiro/ 2010. As macrófitas haviam sido arrancadas ou cortadas e deixadas na água por moradores do local, à montante do ponto de coleta. Foram observados na análise das amostras, respectivamente, em dezembro/2009 e janeiro/2010: menores valores de OD e $\mathrm{pH}$, e maiores valores para a turbidez do que os outros pontos de coleta. A retirada das plantas provocou revolvimento e ressuspensão de sedimentos do fundo, alterando na qualidade da água do ribeirão. Nos meses seguintes à ocorrência, no período de fevereiro a maio/2010, foram observados os maiores valores obtidos para a turbidez no PT2 (em desacordo com o CONAMA), fazendo uma análise temporal no período observado. Em fevereiro e março/2010, também houve incremento de $\mathrm{PT}_{\text {e }} \mathrm{NO}_{3}{ }^{-}$. Acredita-se que os nutrientes do meio aquático que tinham sido absorvidos pelas plantas foram sendo disponibilizados para a água, porque as mesmas foram deixadas no local. Estas observações indicam que a capacidade das macrófitas funcionarem como um filtro para o manancial ficou prejudicada.

Para a represa, as maiores médias de turbidez foram obtidas no PR1, justificado por localizar-se em uma região de grande mistura da zona fluvial (Thornton, 1990; Soares et al., 2008). Os valores máximos obtidos para a turbidez nos três pontos do reservatório ocorreram 
em abril/2010. Levando-se em conta que a represa é um ambiente raso, fatores como correntes de vento que revolvem os sedimentos do fundo podem ter sido a causa do processo (Ford, 1990). Os valores máximos para a turbidez obtidos nos afluentes ocorreram no período de cheia. Considerando que os valores máximos para o reservatório ocorreram no período de estiagem, pode-se inferir que a pluviosidade interfere mais na turbidez dos afluentes, que são ambientes mais frágeis e vulneráveis do que o reservatório. O grande desvio padrão observado para todos os pontos demonstra a grande variação sazonal para este parâmetro.

Nos sistemas estudados, os valores de turbidez variaram de 1,00 a 126,70 UNT. Estes ambientes são desprovidos de mata ciliar e áreas florestadas em quase toda a sua extensão, consequência do mau uso das terras da região. Estes valores encontrados são considerados altos, se comparados com águas de bacias hidrográficas recobertas por floresta de Mata Atlântica, que são da ordem de 0,15 a 4,9 UNT (Silva et al., 2009). Isso mostra a importância da presença e manutenção de cobertura vegetal na preservação dos corpos hídricos, pois funcionam como um filtro para a água.

\subsection{Sólidos totais}

Todos os resultados obtidos neste estudo atenderam aos limites definidos pelo CONAMA. Os máximos para todos os pontos foram registrados em dezembro/2009, fato associado à alta pluviosidade deste mês. Na represa, foi constatado à montante dos pontos PR1 e PR3, obras de terraplanagem com movimentação de terra, provocando assoreamento na margem direita em novembro e dezembro/2009. Neste último mês, as máximas concentrações de sólidos totais podem estar relacionadas aos altos valores para a DBO, além de baixos índices para OD e pH, obtidos para a mesma amostra nos dois pontos amostrais. Além disso, no mesmo período citado, ocorreu à montante do PR1 queima de vegetação na margem direita, que deixou o solo exposto, agravando a situação na zona fluvial. As intensas chuvas de dezembro/2009 potencializaram os efeitos das interferências antrópicas observadas no entorno do manancial para os dois pontos citados.

A maior média de todos os pontos foi observada no PR3. Isso demonstra que a região próxima à barragem da represa é receptora de sedimentos provenientes de processos erosivos das margens à montante, bem como do escoamento superficial de toda a bacia de drenagem. Este ponto deveria apresentar menores concentrações de sólidos totais, uma vez que está próximo à zona lacustre.

\subsection{Demanda Bioquímica de Oxigênio (DBO)}

Todos os resultados estão em desacordo com o CONAMA, exceto no mês de janeiro para o PR2, onde foi obtido o valor mínimo de $2,70 \mathrm{mg} . \mathrm{L}^{-1}$.

O valor máximo registrado ocorreu no córrego Grama (PT1), em abril/2010. As intensas chuvas de março $(320,6 \mathrm{~mm}$, de acordo com a EPRJP) provocaram o revolvimento e ressuspensão de sedimentos acumulados em toda a área brejosa coberta por macrófitas na margem direita e à montante do ponto de coleta, bem como o aumento do volume da água do córrego. O transporte foi facilitado pelo maior fluxo, incrementando o teor de carga orgânica na água. Este afluente também apresentou a maior média e a justificativa está na vulnerabilidade deste ambiente ao escoamento superficial. Sua margem esquerda possui um pequeno talude que frequentemente sofre capina e remoção de vegetação ciliar, pelos moradores do entorno, fato que compromete a qualidade hídrica deste córrego. As características lênticas proporcionadas pela proliferação de macrófitas em sua margem direita, também favorecem o acúmulo de nutrientes e carga orgânica na água.

$\mathrm{Na}$ represa, em janeiro/ 2010 foram observadas erosões na margem direita da represa, à montante do PR3. As alterações na qualidade da água foram percebidas, fato que causa preocupação por estar próximo à Estação de Tratamento de Água (ETA). Além da 
concentração máxima de DBO para este ponto, também houve valores em desacordo o CONAMA para o $\mathrm{pH}$, OD e PT na mesma amostra.

\subsection{Nitrato $\left(\mathrm{NO}_{3}{ }^{-}\right)$}

Neste estudo, todos os resultados referentes a este parâmetro estiveram em conformidade com os limites estabelecidos pelo CONAMA.

A máxima concentração para o $\mathrm{NO}_{3}^{-}$no PR1 em março/2010, coincidiu com valores acima da média para este ponto em relação aos seguintes parâmetros: turbidez, DBO e PT. O fato pode estar relacionado ao assoreamento proveniente de movimentações de terra provocado por moradores do local, fato observado em vários pontos da margem direita, à montante do PR1, indicando o aporte de materiais presentes no solo para a represa. $\mathrm{O}$ maior índice pluviométrico do período também foi registrado neste mês, o que agravou a situação.

\subsection{Fósforo total (PT)}

Neste estudo, os picos de PT observados em julho/ 2009 nos cinco pontos amostrais ocorreram após um período de seca, seguido de chuvas ocorridas anteriormente ao dia da coleta. As fontes difusas de poluição contribuíram para esta ocorrência, agravando a situação. Este fato também foi observado por Haddad (2007) no monitoramento do rio São Miguel (Minas Gerais, Brasil).

A concentração máxima e a maior porcentagem de resultados em desacordo com o CONAMA ocorreram no PT1, justificado pelas características lênticas deste ambiente. Na represa, a máxima se deu no PR1, o que era de se esperar, por estar próximo à zona fluvial.

Porém, fato que chamou a atenção foi que, apesar da pouca diferença, a maior média dos pontos da represa e a maior porcentagem de resultados em desacordo com o CONAMA foram obtidas no PR3. Isso indica que a zona lacustre está sendo impactada por fontes de fósforo. Estas regiões, geralmente são pobres em relação a este nutriente (Kimmel et al., 1990; Pagioro et al., 2005 e Soares et al., 2008), porém, isso não foi observado para a represa Dr. João Penido. Conforme já foi comentado, esta zona da represa é região receptora de sedimentos, e como eles transportam fósforo, ocorre o incremento deste parâmetro na água.

As médias dos afluentes foram maiores, se comparadas ao reservatório, fato também observado por Lamparelli (2004) na rede de monitoramento do estado de São Paulo.

\subsection{Clorofila $a$}

Todos os resultados obtidos atenderam aos limites do CONAMA. Pagioro et al. (2005) citam que existe uma relação positiva entre a clorofila $a$ e o PT, indicando que ele estimula a biomassa fitoplanctônica. Esta abordagem foi evidenciada neste estudo, pelos picos registrados para o PT em todos os pontos em julho/ 2009, coincidindo com as concentrações máximas para a clorofila $a$ no PT1, PR2 e PR3. O PR1 teve concentração de clorofila $a$ próxima à máxima obtida para esta mesma amostra. Nesse mês, somente para o PT2, a relação entre os parâmetros foi inversa, sendo obtida a mínima da clorofila $a$ na mesma amostra em que foi registrada a máxima para o PT. Vários fatores influenciam a produtividade do fitoplâncton, além da disponibilidade de nutrientes. Fatores físicos, como a velocidade da água, e as consequentes taxas de sedimentação, influenciam a transparência da água e a turbulência do ambiente (Lamparelli, 2004; Soares et al., 2008). O maior fluxo de água neste ponto amostral do ribeirão dos Burros pode explicar esta relação inversa ocorrida em julho para os parâmetros PT e clorofila $a$.

A represa apresentou as maiores médias, se comparada aos córregos, fato comum de acontecer e que também foi observado por Lamparelli (2004) nos corpos d'água do estado de São Paulo. Por ser ambiente lêntico, o reservatório proporciona maior incidência de luz e acúmulo de nutrientes, favorecendo o incremento da concentração de clorofila $a$. 
A maior média dos córregos ocorreu no PT1, justificada pelas características lênticas deste afluente. A maior média da represa ocorreu no PR1, demonstrando maior tendência à eutrofização deste ponto, inclusive por estar mais próximo da entrada dos tributários.

Em junho/ 2010, o córrego Grama (PT1) apresentou muita terra exposta proveniente de capina e remoção da vegetação ciliar em sua margem esquerda. Acredita-se que este fato está relacionado aos resultados encontrados nas amostras analisadas, que indicaram valor mínimo para a clorofila $a$, bem como valores acima da média para a turbidez e resultados de OD, PT e DBO em desacordo com o CONAMA.

\subsection{Coliformes termotolerantes}

As bactérias do grupo coliformes são consideradas as principais indicadoras de contaminação fecal (CETESB, 2010). Foi verificado que todas as amostras apresentaram resultados bem inferiores aos limites definidos pelo CONAMA, sendo todas consideradas "próprias" e de "excelente" qualidade, em relação a este parâmetro.

\subsection{2. Índice de Qualidade da Água (IQA)}

Os Índices de Qualidade da Água (IQA) se baseiam principalmente em fatores limnológicos e físico-químicos (Carvalho et al., 2000). Com base nos resultados do IQA, foi feita uma análise espacial por ponto amostrado, avaliando-se e caracterizando-se a qualidade da água de cada um.

Com relação ao parâmetro coliformes termotolerantes, onde os valores não foram determinados exatamente $(<3,0)$, foi utilizado o valor 3,0 para os cálculos do IQA. Este procedimento também é adotado pelo IGAM no monitoramento das águas superficiais de Minas Gerais.

O IQA excelente não foi observado em nenhum ponto. Esta condição vem sendo observada no desenvolvimento do projeto "Águas de Minas" desde 1997, na maioria dos corpos d'água monitorados pelo IGAM (2010) no estado de Minas Gerais.

Os resultados de IQA, bem como a estatística descritiva, estão demonstrados na Tabela 4.

Tabela 4. Resultados de IQA e porcentagens obtidas para cada classificação de qualidade da água nos pontos amostrais estudados.

\begin{tabular}{cc|ccc|ccc}
\hline \multirow{2}{*}{ Pontos } & & $\begin{array}{c}\text { Variação } \\
\text { do IQA }\end{array}$ & $\begin{array}{c}\text { Média } \\
\text { IQA }\end{array}$ & $\begin{array}{c}\text { Desvio } \\
\text { Padrão }\end{array}$ & \multicolumn{2}{c}{ Qualidade da Água (IQA) } \\
\cline { 6 - 8 } & & & & & Ruim & Médio & Bom \\
\hline \multirow{2}{*}{ Tributários } & PT1 & 61,6 a 72,5 & 65,7 & 4,2 & - & $85,7 \%$ & $14,3 \%$ \\
& PT2 & 47,0 a 72,9 & 58,9 & 10,0 & $28,6 \%$ & $57,1 \%$ & $14,3 \%$ \\
\hline \multirow{2}{*}{ Represa } & PR1 & 63,6 a 72,2 & 68,1 & 2,9 & - & $71,4 \%$ & $28,6 \%$ \\
& PR2 & 70,8 a 79,0 & 74,9 & 3,2 & - & - & $100,0 \%$ \\
& PR3 & 61,6 a 75,2 & 68,9 & 4,5 & - & $71,4 \%$ & $28,6 \%$ \\
\hline
\end{tabular}

\subsection{Análise dos tributários}

Em uma análise mais ampla, o nível de qualidade da água dos afluentes variou de "ruim" a "bom", com predominância do "médio".

$\mathrm{O}$ teste $\mathrm{t}$ de Student aplicado revelou que $\mathrm{P}>0,05(\mathrm{P}=0,127)$, ou seja, não existe diferença significativa entre os pontos estudados, a um nível de confiança de $95 \%$. 
No córrego Grama (PT1), houve predominância do IQA médio. Levando-se em conta os pesos de cada parâmetro, a influência maior na deve-se aos altos valores de DBO e PT observados. O nível "bom" foi obtido em janeiro/2010 e os parâmetros que influenciaram neste resultado foram os bons índices de OD e pH observados. Este córrego apresentou maior média do IQA em relação ao ribeirão dos Burros.

No ribeirão dos Burros (PT2), houve predominância do IQA médio devido aos baixos valores de OD e $\mathrm{pH}$, além de altos valores para a DBO. Em fevereiro e março/2010 a qualidade foi "ruim", justificado pelos altos valores para o PT, além dos parâmetros já citados acima. Em janeiro, a qualidade da água foi "boa", sendo que os parâmetros de maior influência foram os baixos teores de $\mathrm{NO}_{3}{ }^{-}$e PT.

\subsection{Análise do reservatório}

De uma maneira geral, o nível de qualidade da água da represa variou de "médio" a "bom".

Ao aplicar a análise de variância ANOVA, verificou-se que $\mathrm{P}<0,05(\mathrm{P}=0,004)$, revelando diferença significativa entre os pontos. O ponto PR2 difere estatisticamente dos pontos PR1 e PR3, e isto pode ser observado também pelos valores das médias.

$\mathrm{O}$ ponto $\mathrm{PR} 1$, próximo à zona fluvial apresentou predominância do IQA médio no período de cheia (dezembro/ 2009 a abril/2010). Os parâmetros que não atenderam à Resolução CONAMA 357/2005 neste período como DBO, pH e PT influenciaram neste resultado. A água esteve com IQA bom nos meses de estiagem (maio e junho/ 2010). Neste período, o pH da água foi próximo à neutralidade e a temperatura da água foi menor.

O IQA no período estudado foi bom em 100,00 \% do total de amostras analisadas no ponto PR2, próximo à zona intermediária. Os parâmetros de maior peso que contribuíram positivamente para esses resultados foram: bons índices de $\mathrm{OD}$ e valores de $\mathrm{pH}$ próximos à neutralidade, bem como menores valores de DBO. Acredita-se que a melhor qualidade das águas neste ponto (se comparada com PR1 e PR3), se deve também às margens preservadas na direção e à montante do PR2. A margem direita, apesar das ocupações, possui mata densa e preservada. A margem esquerda não possui ocupações e não apresentou sinais de erosões. Apesar da ausência de mata ciliar nesta margem, a cobertura do solo com gramíneas ofereceu proteção, dificultando o carreamento de sedimentos para a água. Este ponto apresentou a maior média, indicando melhor qualidade da água.

O ponto PR3 apresentou comportamento semelhante ao PR1, havendo predominância do IQA médio, observado no período de cheia (dezembro/ 2009 a abril/ 2010). As médias praticamente iguais dos dois pontos, também revelam esta similaridade. Os parâmetros que tiveram maior peso nestes resultados foram altos valores de DBO e maiores temperaturas da água. O nível foi bom nos meses de estiagem (maio e junho/ 2010). Contribuíram positivamente para esse resultado, os valores de $\mathrm{pH}$ mais próximos à neutralidade e menores valores de DBO e temperatura da água.

Este ponto localizado na zona lacustre deveria apresentar águas de melhor qualidade, porém isso não foi observado. Foi identificado que esta região próxima à barragem sofre influência de processos erosivos que ocorrem à montante da represa, principalmente na margem direita entre o PR2 e o PR3.

\subsection{5. Índice de Estado Trófico (IET)}

Carlson (1977) afirma que o IET não equivale a um índice de qualidade de água. O termo qualidade está mais relacionado aos seus usos múltiplos e implica em um julgamento que deve ser separado do estado trófico.

Os resultados de IET, bem como a estatística descritiva, estão demonstrados na Tabela 5. 
Tabela 5. Resultados de IET e porcentagens obtidas para cada estado trófico nos pontos amostrais estudados.

\begin{tabular}{|c|c|c|c|c|c|c|c|c|}
\hline \multirow{2}{*}{ Ponto } & & \multirow{2}{*}{$\begin{array}{l}\text { Variação do } \\
\text { IET }\end{array}$} & \multirow{2}{*}{$\begin{array}{l}\text { Média } \\
\text { IET }\end{array}$} & \multirow{2}{*}{$\begin{array}{l}\text { Desvio } \\
\text { Padrão }\end{array}$} & \multicolumn{4}{|c|}{ Estado Trófico (IET) } \\
\hline & & & & & Super-eutrófico & Eutrófico & Mesotrófico & Oligotrófico \\
\hline \multirow{3}{*}{ Tributários } & PT1 & 50,9 a 63,7 & 55,6 & 3,3 & $8,3 \%$ & - & $83,3 \%$ & $8,3 \%$ \\
\hline & & & & & & & & \\
\hline & PT2 & 48,4 a 57,6 & 53,0 & 3,1 & - & - & $75,0 \%$ & $25,0 \%$ \\
\hline \multirow{3}{*}{ Represa } & PR1 & 50,3 a 62,6 & 53,9 & 3,5 & - & $8,3 \%$ & $50,0 \%$ & $41,6 \%$ \\
\hline & PR2 & 48,5 a 62,3 & 53,7 & 3,9 & - & $8,3 \%$ & $58,3 \%$ & $33,3 \%$ \\
\hline & PR3 & 48,2 a 62,3 & 53,6 & 3,9 & - & $8,3 \%$ & $58,3 \%$ & $33,3 \%$ \\
\hline
\end{tabular}

\subsection{Análise dos tributários}

Aplicando-se o teste t de Student para os córregos, encontrou-se $\mathrm{P}>0,05(\mathrm{P}=0,063)$. Isso mostra que estatisticamente, não existe diferença significativa entre os pontos, com um nível de confiabilidade de $95 \%$.

No córrego Grama (PT1), o fluxo de água é bem mais lento. Este fato favorece maiores concentrações de PT e clorofila $a$, indicando maior tendência à eutrofização e consequentemente explica a maior média para o IET encontrada para este ponto, em relação ao ribeirão dos Burros. O PT1 apresentou predominância do estado "mesotrófico" durante o período observado. Em julho/ 2009, a classificação foi "supereutrófico", justificado pelo pico observado para o PT em todos os pontos, além do valor de clorofila $a$ acima da média para este ponto, na mesma amostra. Houve apenas uma ocorrência para o estado "oligotrófico" neste ponto amostral, de um total de doze amostras analisadas.

O ribeirão dos Burros (PT2) também apresentou estado "mesotrófico" predominante. Apesar da infestação de macrófitas impedir o curso normal do córrego, há maior fluxo de água no ponto de coleta. Isso influenciou nos baixos índices de clorofila $a$ obtidos, permitindo menor média para o IET em relação ao córrego Grama. Do total analisado, houve três ocorrências para o estado "oligotrófico" neste ponto.

\subsection{Análise do reservatório}

O teste estatístico ANOVA aplicado revelou que $\mathrm{P}>0,05(\mathrm{P}=0,853)$, não existindo diferença significativa entre os 3 pontos, com um nível de confiança de $95 \%$.

Em uma primeira análise, o grau de trofia da represa variou de "oligotrófico" a "eutrófico". Porém, observou-se predominância do estado "mesotrófico", indicando produtividade intermediária, com possíveis implicações sobre a qualidade e o uso da água.

Observou-se que as médias do IET foram praticamente iguais nos três pontos da represa. Portanto, a tendência geral de apresentar características eutróficas na parte alta do reservatório, e oligotróficas na zona próxima à barragem (Lamparelli, 2004; Kimmel et al., 1990; Pagioro et al., 2005) não foi observada na represa Dr. João Penido.

As tendências maiores de eutrofização puderam ser evidenciadas no mês de julho/2009, demonstrando alta produtividade do ecossistema em relação às suas condições naturais. Os picos de PT observados neste mês, aliados aos valores de clorofila $a$ acima da média para todos os pontos do reservatório, justificaram a classificação "eutrófico" verificada para os três pontos amostrais neste mês. 


\section{CONCLUSÕES}

- O uso e ocupação do solo na área da bacia da represa Dr. João Penido não têm sido adequadas para que o manancial seja utilizado para abastecimento público de Juiz de Fora, evidenciando deterioração da qualidade de suas águas.

- As principais interferências antrópicas identificadas, que possivelmente provocaram alterações na qualidade da água devido à ocupação ilegal no entorno do manancial, foram: movimentos de terra às margens da represa, remoção inadequada de macrófitas, lançamento inadequado de efluentes domésticos, retirada e queima de vegetação ciliar.

- A remoção da mata ciliar e da cobertura vegetal que as áreas da represa vêm sofrendo ao longo do tempo, tem causado impactos na qualidade hídrica do sistema. Isso torna os ambientes mais vulneráveis aos impactos da água de chuva, permitindo maior escoamento superficial de materiais para a água. Isso ficou bem evidenciado nos parâmetros: $\mathrm{pH}$, turbidez e sólidos totais, que sofreram variação sazonal bem significativa.

- Os afluentes demonstraram maior sensibilidade e vulnerabilidade em relação ao impacto das águas pluviais, se comparados ao reservatório.

- Os pontos próximos às zonas fluvial e lacustre são os mais impactados da represa, apresentando predominância do IQA médio. O ponto próximo à zona intermediária apresentou águas de melhor qualidade, com IQA bom.

- O sistema afluentes e represa apresentou característica dominante de estado "mesotrófico" para os pontos amostrais estudados.

Este trabalho evidenciou que é preciso adotar medidas mitigadoras visando à redução e controle do aporte de carga orgânica, nutrientes e sedimentos para a água, bem como a contenção do assoreamento, erosão e eutrofização dos corpos hídricos. Disciplinar e fiscalizar com mais rigor o uso e a ocupação do solo da região estudada também é uma das importantes tarefas que devem ser promovidas para a sua preservação. É necessário também dar prosseguimento aos estudos aqui apresentados para continuar avaliando a qualidade hídrica e o estado trófico do principal sistema de abastecimento de água de Juiz de Fora.

Espera-se que este trabalho seja útil para possibilitar a elaboração e execução de um plano de gestão integrada para a represa Dr. João Penido, conforme prevê a Política Nacional dos Recursos Hídricos (Brasil, 1997). Cabe destacar a importância da participação de todos os atores envolvidos, unificados dentro do conceito de gerenciamento ambiental da bacia (Pinder, 2013; Thornton et al., 2013a; 2013b).

Embora a natureza tenha maneiras para acomodar as perturbações e stress sofridos, a determinação da saúde dos ambientes lacustres é uma construção completamente humana (Thornton et al., 2013a). Portanto, constitui tarefa imprescindível das autoridades e responsabilidade de todos na preservação dos recursos hídricos, para que se possa garantir água de boa qualidade para os atuais e futuros usuários.

\section{AGRADECIMENTOS}

Os autores agradecem ao CNPq pelo auxílio financeiro, e à Quarta Companhia de Polícia Militar Independente de Meio Ambiente e Trânsito ( $4^{\text {a }}$ Cia PM Ind MAT) de Juiz de Fora, pelo auxílio na coleta das amostras.

\section{REFERÊNCIAS}

AMERICAN PUBLIC HEALTH ASSOCIATION (APHA). Standard methods for the examination of water and wastewater. 20th ed. Washington, 1998. 
ASSOCIAÇÃO BRASILEIRA DE NORMAS E TÉCNICAS (ABNT). NBR 9898. Preservação e técnicas de amostragem de efluentes líquidos e corpos receptores. Rio de Janeiro, 1987.

BRASIL. Lei $\mathbf{n}^{\mathbf{0}}$ 9.433, de 8 de janeiro de 1997. Disponível em: <http://www.planalto. gov.br/ccivil_03/Leis/L9433.htm>. Acesso em: 13 fev. 2011.

BRASIL. Ministério do Meio Ambiente. Conselho Nacional de Meio Ambiente (CONAMA). Resolução no 357, de 17 de março de 2005. Disponível em: <http://www.mma. gov.br/port/conama/legiano1.cfm?codlegitipo=3\&ano=2005>. Acesso em: 28 fev. 2010.

BRITO, S. L.; MAIA-BARBOSA, P. M.; PINTO-COELHO, R. M. Zooplankton as an indicator of trophic conditions in two large reservoirs in Brazil. Lakes \& Reservois: Research \& Management, v. 16, p. 253-264, 2011. http://dx.doi.org/10.1111/j.14401770.2011.00484.x

CARLSON, R. E. A trophic state index for lakes. Limmology and Oceanography, v. 22, n. 2, p. 361-369, 1977.

CARNEIRO, C.; PEGORINI, E. S.; ANDREOLI, C. V. Introdução. In: ANDRREOLI, C. V. Gestão integrada de mananciais de abastecimento eutrofizados. Curitiba: Finep, 2005. p. 25-44.

CARVALHO, A. R.; SCHLITTLER, F. H. M.; TORNISIELO, V. L. Relações da atividade agropecuária com parâmetros físicos químicos da água. Química Nova, v. 23, n. 5, p. 618-622, 2000. http://dx.doi.org/10.1590/S0100-40422000000500009

COMPANHIA AMBIENTAL DO ESTADO DE SÃO PAULO (CETESB). Água, rios e reservatórios: variáveis de qualidade das águas. São Paulo, 2010. Disponível em: <http://www.cetesb.sp.gov.br/Agua/rios/variaveis.asp\#cor>. Acesso em: 20 fev. 2010.

COMPANHIA DE SANEAMENTO MUNICIPAL (CESAMA) (Juiz de Fora). Mananciais. Represa Dr. João Penido. Disponível em: <http://www.cesama.com.br〉. Acesso em: 07 fev. 2010.

CUNHA, D. G. F.; CALIJURIA, M. C.; LAMPARELli, M. C. A trophic state index for tropical/subtropical reservoirs (TSItsr). Ecological Engineering, v. 60, p. 126-134, 2013.

CARMO M. S. do; BOAVENTURA G. R.; OLIVEIRA E. C. Geoquímica das águas da bacia hidrográfica do rio Descoberto, Brasília/ DF - Brasil. Química Nova, v. 28, n. 4, p. 565-574, 2005. http://dx.doi.org/10.1590/S0100-40422005000400002

DORES E. F. G. de C.; DE-LAMONICA-FREIRE E. M. Contaminação do ambiente aquático por pesticidas, estudo de caso: Águas usadas para consumo humano em Primavera do Leste, Mato Grosso - Análise preliminar. Química Nova, v. 24, n. 1, p. 27-36, 2001. http://dx.doi.org/10.1590/S0100-40422001000100007

ESTEVES F. de A. Fundamentos de limnologia. 2. ed. Rio de Janeiro: Interciência, 1998.

FERNANDES L. F.; LAGOS, P. D.; WOSIACK A. C.; PACHECO C. V.; DOMINGUES L.; ZENDER-ALVES L. et al. Comunidades fitoplanctônicas em ambientes lênticos. In: ANDREOLI, C. V.; CARNEIRO, C. Gestão integrada de mananciais de abastecimento eutrofizados. Curitiba: Finep, 2005. p. 303-366.

FORD D. E. Reservoir transport processes. In: Thornton, K. W. et al. Reservoir limnology: ecological perspectives. New York: John Wiley \& Sons, 1990. p. 15-41. 
HADDAD E. A. Influência antrópica na qualidade da água da Bacia Hidrográfica do Rio São Miguel, Carste do Alto São Francisco, Minas Gerais. 2007. 156 f. Dissertação (Mestrado em Geografia) - Universidade Federal de Minas Gerais, Belo Horizonte, 2007.

INSTITUTO MINEIRO DE GESTÃO DAS ÁGUAS - IGAM. Monitoramento da qualidade das águas superficiais no estado de Minas Gerais. Relatório Trimestral $1^{\circ}$ trimestre de 2010. Belo Horizonte, 2010. Disponível em: <http://www.igam.mg.gov. br/images/stories/qualidade/relatorio-trimestra-1-trim-2010.pdf.>. Acesso em: 15 jun. 2010 .

JUIZ DE FORA. Prefeitura. Juiz de Fora sempre. Plano Diretor de Desenvolvimento Urbano. Juiz de Fora: Funalfa Edições, 2004.

JUIZ DE FORA. Prefeitura. Secretaria de Planejamento e Desenvolvimento Econômico (SPDE). Ortofoto. Juiz de Fora, 2007.

KIMMEL, B. L.; LIND, O. T.; PAULSON, L. J. Reservoir primary production. In: THORNTON, K. W. et al. Reservoir limnology: ecological perspectives. New York: John Wiley \& Sons, 1990. p. 133-193.

LAMPARELli M. C. Graus de trofia em corpos d'água do estado de São Paulo: avaliação dos métodos de monitoramento. 2004. 238 f. Tese (Doutorado em Ciências na Área de Ecossistemas Terrestres e Aquáticos) - Universidade de São Paulo, São Paulo, 2004.

LEME ENGENHARIA S.A. Plano diretor de abastecimento de água da área urbana de Juiz de Fora. Recursos hídricos. v. IV/IX. Juiz de Fora: Prefeitura Municipal de Juiz de Fora, 1985.

LIU, Y.; WANG, Y.; SHENG, H.; DONG, F.; ZOU, R.; ZHAO, L. et al. Quantitative evaluation of lake eutrophication responses under alternative water diversion scenarios: a water quality modeling based statistical analysis approach. Science of the Total Environment, v. 468-469, p. 219-227, 2014. http://dx.doi.org/10.1016/j.scitotenv .2013 .08 .054

MINAS GERAIS. Conselho Estadual de Política Ambiental (COPAM). Deliberação Normativa no 16, de 24 de setembro de 1996. Disponível em: <http://www.siam.mg. gov.br/sla/download.pdf?idNorma=113>. Acesso em: 28 fev. 2010.

MINAS GERAIS. Secretaria de Estado do Meio Ambiente e Desenvolvimento Sustentável de Minas Gerais (SEMAD). Sistema de cálculo da qualidade da água (SCQA): estabelecimento das equações do índice de qualidade das águas (IQA). Relatório 1, 2005. Belo Horizonte: SEMAD, 2005. Disponível em: <http://www.engenharia ambiental.unir.br/admin/prof/arq/calculo-IQA.pdf>. Acesso em: 10 set. 2009.

PAGIORO T. A.; ROBERTO M. DO C.; THOMAZ S. M., PIERINI S. A.; TAKA M. Zonação longitudinal das variáveis limnológicas abióticas em reservatórios. In: RODRIGUES, L. (Org.). Biocenose em reservatórios: padrões espaciais e temporais. São Carlos: RiMa, 2005. p. 39-46.

PIMENTA, A. M.; ALBERTONI, E. F.; PALMA-SILVA, C. Characterization of water quality in a small hydropower plant reservoir in southern Brazil. Lakes \& Reservoirs: Research \& Management, v. 17, p. 243-251, 2012. http://dx.doi. org/10.1111/lre.12007 
PINDER, J. R. Lakes, landscapes and locals: pooling partnership resources to create sustainable lake catchments. Lakes \& Reservoirs: Research \& Management, v. 18, p. 15-25, 2013. http://dx.doi.org/10.1111//re.12016

RANGEL, L. M; SILVA, L. H. S.; ROSA, P.; ROLAND, F.; HUSZCAR, V. L. M. Phytoplankton biomass is mainly controlled by hydrology and phosphorus concentrations in tropical hydroelectric reservoirs. Hydrobiologia, v. 693, n. 1, p.13 - 28, 2012. http://dx.doi.org/10.1007/s10750-012-1083-3

SILVA, A. P. de S.; DIAS, H. C. T.; BASTOS, R. K. X.; SILVA, E. Qualidade da água do reservatório da Usina Hidrelétrica (UHE) de Peti, Minas Gerais. Revista Árvore, Viçosa, v. 33, n. 6, p. 1063-1069, 2009. http://dx.doi.org/10.1590/S0100-67622009000600009

SILVA, N. da; NETO, R. C.; JUNQUEIRA, V. C. A.; SILVEIRA, N. F. de A. Manual de métodos de análise microbiológica da água. São Paulo: Varela, 2005.

SOARES, M. C. S.; MARINHO, M. M.; HUSZAR, V. L. M.; BRANCO, C. W. C.; AZEVEDO, S. M. F. O. The effects of water retention time and watershed features on the limnology of two tropical reservoirs in Brazil. Lakes \& Reservoirs: Research \& Management, v. 13, p. 257-269, 2008. http://dx.doi.org/10.1111/j.1440-1770. 2008.00379.x

STANTON, A. G. Primer of biostatistics - Version 4.0. $4^{\text {th }}$ ed. New York: McGraw Hill, 1997.

THORNTON, J. A.; LIN, H.; SLAWSKI, T. M. People and ponds: the participatory role of humans in Integrated Lake Basin Management. Lakes \& Reservoirs: Research \& Management, v. 18, p. 3-4, 2013a. http://dx.doi.org/10.1111//re.12020

THORNTON, J. A.; SLAWSKI, T. M.; OLSON, E. Protecting in partnership: the Mukwonago River Basin Protection Plan. Lakes \& Reservoirs: Research \& Management, v. 18, p. 67-80, 2013b. http://dx.doi.org/10.1111//re.12021

THORNTON, K. W. Sedimentary process. In: THORNTON, K. W. et al. Reservoir limnology: ecological perspectives. New York: John Wiley \& Sons, 1990. p. 43-69.

VIEIRA, S. Análise de variância (ANOVA). São Paulo: Atlas, 2006.

VON SPERLING, E. Morfologia de lagos e represas. Belo Horizonte: Departamento de Engenharia Sanitária e Ambiental da Universidade Federal de Minas Gerais (DESA/UFMG), 1999.

\section{ERRATA}

Revista Ambiente \& Água, Taubaté, v.9 n.1, jan. - mar. 2014

doi: 10.4136/ambi-agua.1438

BUCCI, Magaly H. S.; OLIVEIRA, Luiz Fernando C. de. Índices de Qualidade da Água e de Estado Trófico na Represa Dr. João Penido (Juiz de Fora, MG). Rev. Ambient. Água, Taubaté, v. 9, n. 1, Mar. 2014. Available from <http://www.scielo.br/scielo.php?script=sci_arttext\&pid=S1980-993X2014000100013\&lng=en\&nrm=iso〉. http://dx.doi.org/10.4136/ambi-agua.1290.

1) página 135: onde se lê: "PT: - concentração de fósforo total ...", leia-se: PT: concentração de fósforo total ...;

2) página 143: onde se lê: "O ponto PR2 difere estatisticamente dos pontos 1 e 2, ...", leia-se: "O ponto PR2 difere estatisticamente dos pontos PR1 e PR3, ...”. 


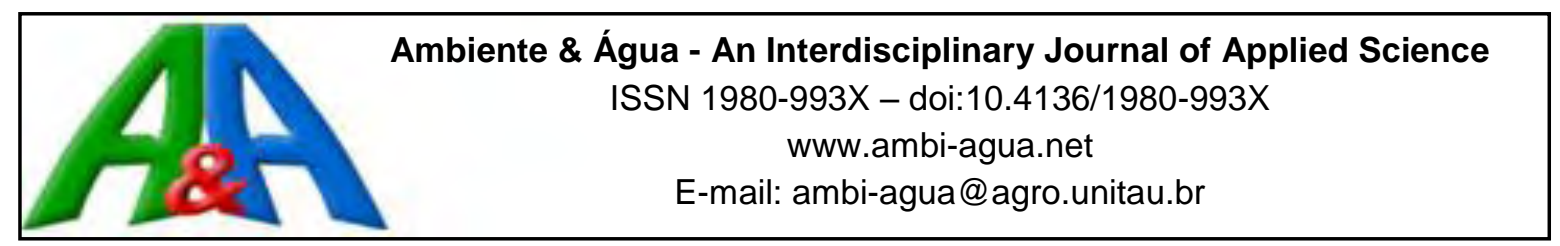

\title{
Análise de BTEX em água: comparação entre duas colunas cromatográficas
}

\author{
doi: 10.4136/ambi-agua.1171
}

Received: 16 Aug. 2013; Accepted: 24 Feb. 2014

\section{Danielle de Almeida Carvalho ${ }^{1 *}$; Rosália Maria de Oliveira ${ }^{1}$; Célia Regina Sousa da Silva²; Priscila Tamiasso Martinhon²; Sérgio Alves da Silva ${ }^{1}$}

\footnotetext{
${ }^{1}$ Escola Nacional de Saúde Pública Sergio Arouca, FIOCRUZ - Rio de Janeiro, RJ, Brasil

${ }^{2}$ Universidade Federal do Rio de Janeiro - Rio de Janeiro, RJ, Brasil.

*Autor correspondente: e-mail: danny@ensp.fiocruz.br, rosalia@ensp.fiocruz.br, sousa@iq.ufrj.br, pris-martinhon@hotmail.com, sergio.silva@incqs.fiocruz.br
}

\section{RESUMO}

Este estudo teve como objetivo a implementação e a validação de uma metodologia por CG-DIC para a determinação de Benzeno, Tolueno, Etilbenzeno e Xilenos, BTEX, em água potável, como indicadores de contaminação. A metodologia utilizada foi realizada em quatro etapas: a primeira consistiu na separação adequada dos analitos da matriz comparando duas colunas cromatográficas com características diferentes (Supelcowax ${ }^{\mathrm{TM}} 10$ e HP-5); a segunda, na extração dos seis compostos (BTEX) variando o tipo de solvente utilizado, o tempo e a velocidade de extração; as duas últimas etapas consistiram, respectivamente, no tratamento estatístico dos dados obtidos e na validação da metodologia. A coluna Supelcowax ${ }^{\mathrm{TM}} 10$ apresentou melhores resultados na separação dos BTEX. A recuperação mais eficiente foi obtida usando microextração líquido-líquido utilizando o isooctano como solvente, cujo percentual variou de 57,8 a $89,8 \%$. A linearidade foi observada para todos os compostos estudados na faixa de trabalho.

Palavras-chave: contaminação da água potável, microextração líquido-líquido.

\section{Analysis of BTEX in water: comparison between two chromatographic columns}

\section{ABSTRACT}

This study aimed to implement and validate the GC-FID methodology to determine benzene, toluene, ethylbenzene and xylenes, or "BTEX," as contamination indicators in drinking water. The methodology included four steps: the first was to adequately separate analytes from the matrix by comparing two different chromatography columns (Supelcowax ${ }^{\mathrm{TM}} 10$ e HP-5); the second step was the extraction of six compounds of (BTEX) using various types of solvents, extraction times and speeds; the third step statistically analyzed the resulting data; and the final step validated the methodology. Column Supelcowax ${ }^{\mathrm{TM}} 10$ had better results in BTEX separation. The most effective recovery was achieved by using liquid-liquid micro-extraction with isooctane as solvent, which resulted in a 
recovery percentage of 57.8 to $89.8 \%$. Linearity was observed for all compounds studied in the work range.

Keywords: drinking water contamination, liquid-liquid micro-extraction.

\section{INTRODUÇÃO}

Com o crescente aumento da população e da atividade industrial, o tratamento e condicionamento da água potável, assim como a proteção do meio ambiente, é uma das principais preocupações da sociedade moderna. O fornecimento adequado de água potável é uma das necessidades primárias para uma boa saúde e, nesse contexto, a água subterrânea é uma fonte alternativa de abastecimento de água para o consumo humano (Gobato e Lanças, 2001). Em geral, as águas subterrâneas são potáveis e dispensam tratamento prévio; no entanto, quando sua exploração é realizada em área urbana, os maiores problemas de contaminação destes mananciais são atribuídos ao vazamento de combustíveis dos tanques de armazenamento subterrâneo dos postos de gasolina (Silva et al., 2002).

A contaminação da água subterrânea por gasolina é atribuída aos hidrocarbonetos aromáticos, que são os compostos mais solúveis e móveis da fração da gasolina, tais como a mistura BTEX, de conhecido potencial de contaminação e toxicidade à saúde humana e ambiental. Os efeitos adversos da exposição humana a essas substâncias incluem danos ao fígado, rins, coração, pulmões e sistema nervoso (WHO, 1996a; 1996b; 2000a; 2000b; 2004).

No Brasil, devido ao grande aumento do número de postos de combustíveis surgidos nas décadas de 70 e 80 , supõe-se que a vida útil dos tanques de armazenamento esteja próxima do final, aumentando a possibilidade de vazamentos (Lourenço, 2005), mesmo porque, estes contaminantes são os que primeiro atingem o lençol freático (Corseuil e Marins, 1997).

Assim, as responsabilidades relativas ao controle e vigilância da qualidade da água que chega às residências é obrigação legal das empresas de abastecimento e segue a Norma de Potabilidade regulamentada pela Portaria $\mathrm{N}^{\circ}$ 2914, de 12 de dezembro de 2011, do Ministério da Saúde. Segundo a Lei No 11.097, de 13/01/2005, publicada no Diário Oficial da União (DOU), em 14/01/2005, é missão da Agência Nacional de Petróleo a regulação, a contratação e a fiscalização das atividades econômicas das indústrias do petróleo, do gás natural e dos biocombustíveis, inclusive a promoção de estudos visando à delimitação de espaços para efeito de concessão das atividades de exploração, desenvolvimento e produção, de modo a preservar o interesse nacional, garantir o abastecimento e proteger os consumidores quanto ao preço e a qualidade dos produtos.

A Tabela 1 mostra a Concentração Máxima Permitida dos BTEX em água para consumo humano em diferentes países.

Tabela 1. Concentração Máxima Permitida dos BTEX em água para consumo humano em diferentes países e documentos orientadores em $\mu \mathrm{g} \mathrm{L}^{-1}$.

\begin{tabular}{l|cccccc}
\hline \multirow{2}{*}{ Substância } & USEPA $^{1}$ & $\begin{array}{c}\text { CONAMA } \\
357 / 2005^{2}\end{array}$ & $\begin{array}{c}\text { Portaria } \\
2914 / 2011^{3}\end{array}$ & $\begin{array}{c}\text { Directive } \\
98 / 83 / \mathrm{EC}^{4}\end{array}$ & ADWG $^{5}$ & GCDWQ $^{6}$ \\
\cline { 2 - 7 } & EstadosUnidos & Brasil & Brasil & $\begin{array}{c}\text { Comunidade } \\
\text { Européia }\end{array}$ & Austrália & Canadá \\
\hline Benzeno & 5 & 5 & 5 & 1 & 1 & 5 \\
Tolueno & 1000 & 2 & 170 & - & 800 & - \\
Etilbenzeno & 700 & 90 & 200 & - & 300 & - \\
Xilenos & 10.000 & 300 & 300 & - & 600 & - \\
\hline
\end{tabular}

Fontes: ${ }^{1}$ USEPA (2004); ${ }^{2}$ Brasil (2005); ${ }^{3}$ Brasil (2011b); ${ }^{4}$ European Communities (1998); ${ }^{5}$ Australia (2004); ${ }^{6}$ Canada (1996). 
A preocupação principal após um vazamento de combustível é a de tomar providências para circunscrevê-lo à menor área possível, o que facilitará os trabalhos de remediação e, em caso de fonte receptora de água subterrânea, poderá evitar a utilização de água contaminada; tais iniciativas têm o objetivo de preservar a saúde coletiva, minimizando os impactos ambientais e os custos de recuperação da área atingida (Silva, 2002).

Existem várias técnicas desenvolvidas para análise dos compostos BTEX em água. Porém, a maioria depende de equipamentos caros e sofisticados como purge and trap e headspace para a sua detecção. A proposta deste trabalho visa o desenvolvimento e a validação de uma técnica simples de identificação e de quantificação desses compostos, de forma mais rápida e barata do que as já citadas, o que poderá viabilizar a análise em laboratórios dos órgãos reguladores do Brasil, bem como facilitará o controle dos processos de remediação e avaliação da eficiência do mesmo.

A necessidade de métodos de ensaio validados é clara, embora os mecanismos para o desenvolvimento de uma validação intralaboratorial adequada não estejam bem acordados internacionalmente. A maior parte das publicações que tratam de validações intralaboratoriais de métodos de ensaio limitam-se às definições dos principais parâmetros de desempenho e a roteiros genéricos de procedimentos de validação (Green, 1996; EURACHEM, 1998).

A Norma NBR ISO/IEC 17.025 estabelece que devam ser validados métodos utilizados fora dos escopos para os quais foram concebidos e que tenham sido ampliados ou modificados; a validação também se faz necessária em métodos ainda não normatizados e em métodos criados ou desenvolvidos em laboratórios. Entretanto, a velocidade nos avanços científicos e tecnológicos, associada à crescente necessidade de garantia da qualidade gera dificuldades para que os estudos colaborativos acompanhem as demandas, tanto por questões técnicas e organizacionais, quanto por questões infra-estruturais e financeiras.

O presente estudo tem como objetivo o desenvolvimento de uma nova metodologia de extração para a determinação de Benzeno, Tolueno, Etilbenzeno e os isômeros orto, meta e para do Xileno, comumente denominados de BTEX, em água para consumo humano, em níveis de concentração exigidos pela Norma de Potabilidade vigente. Utilizou-se a técnica de Cromatografia à Gás de Alta Resolução por Detecção de Ionização por Chama (CGAR-DIC) como metodologia de análise que foi adequada, implementada e validada. O processo de validação utilizado foi intralaboratorial, tendo como base o documento orientativo do Instituto Nacional de Metrologia e da Eurachem Working Group, além da NBR ISO/IEC 17.025 e estudos publicados na literatura científica.

\section{MATERIAIS E MÉTODOS}

\subsection{Equipamentos e Acessórios}

Cromatógrafo à Gás de Alta Resolução HP 6890, equipado com sistema de injeção automática e Detector de Ionização por Chama; Balança analítica digital - Mettler Toledo AG245, calibrada antes das pesagens com pesos padrões, certificados pelo INMETRO. Placa de aquecimento e agitação Thermolyne NUOVA Stir Plate.

\subsection{Reagentes e Substâncias de Referência utilizados}

Acetona grau de pureza para análise de resíduos; Sulfato de sódio anidro granulado grau de pureza para análise de resíduos (previamante seco em mufla a $400{ }^{\circ} \mathrm{C}$ por $12 \mathrm{~h}$ ); Isooctano grau de pureza para análise de traços orgânicos; Hexano grau de pureza para análise de traços orgânicos; 1-Heptanol grau pureza 98\%; 1-Octanol grau pureza para análise; Coluna Supelcowax ${ }^{\mathrm{TM}} 10$, com $60 \mathrm{~m}$ de comprimento, $0,32 \mathrm{~mm}$ de diâmetro interno e $0,50 \mu \mathrm{m}$ de espessura de filme; Coluna HP-5 com $30 \mathrm{~m}$ de comprimento, $0,32 \mathrm{~mm}$ de diâmetro interno e $0,25 \mu \mathrm{m}$ de espessura de filme. 


\subsection{Metodologia}

A metodologia utilizada foi realizada em 4 etapas: a primeira etapa consistiu na separação adequada dos analitos da matriz comparando duas colunas cromatográficas com características diferentes - Supelcowax ${ }^{\mathrm{TM}} 10$ e HP-5; a segunda etapa consistiu da extração dos seis compostos de interesse (BTEX) variando o tipo de solvente utilizado, o tempo e a velocidade de extração; as duas últimas etapas consistiram, respectivamente, no tratamento estatístico dos dados obtidos e na validação da metodologia, segundo os seguintes parâmetros: seletividade, faixa de trabalho, linearidade, limite de detecção, limite de quantificação e de recuperação.

\subsection{Otimização das condições da análise cromatográfica}

Foram testadas duas colunas cromatográficas com polaridade de fases diferentes, coluna Supelcowax $^{\mathrm{TM}} 10$ e coluna HP-5. Para ambas as colunas foram utilizadas as seguintes condições cromatográficas para a análise de Benzeno, Tolueno, Etilbenzeno e Xilenos:

Equipamento HP 6890, gás de arraste $\mathrm{He}$ com fluxo de $1,8 \mathrm{~mL} \mathrm{~min}^{-1}$; rampas de temperatura - inicial: $40{ }^{\circ} \mathrm{C}$ por 1 minuto, rampa 1: $10^{\circ} \mathrm{C} \min ^{-1}$ até $90{ }^{\circ} \mathrm{C}$, rampa $2: 4{ }^{\circ} \mathrm{C} \mathrm{min}{ }^{-1}$ até $120{ }^{\circ} \mathrm{C}$, rampa 3: $20{ }^{\circ} \mathrm{C} \min ^{-1}$ até $200{ }^{\circ} \mathrm{C}$ por 1 minuto; temperatura do injetor $240{ }^{\circ} \mathrm{C}$; modo de injeção: com divisão de fluxo (Split) 1:10; detector de ionização por chama: temperatura do detector: $240{ }^{\circ} \mathrm{C}$; injetor automático HP 7683; volume de injeção: $1 \mu \mathrm{L}$.

A concentração de trabalho utilizada foi de $10 \mathrm{mg} \mathrm{L}^{-1}$ e os tempos de retenção foram obtidos injetando-se os compostos BTEX, na forma de soluções individuais, na concentração de $1000 \mathrm{mg} \mathrm{L}^{-1}$.

\subsection{Otimização das condições da extração}

A extração líquido-líquido foi utilizada como método de extração. Foram testados dois tipos de solventes em diferentes tempos de extração e velocidades de agitação. Utilizou-se $25,00 \mathrm{~mL}$ de água fortificada com os compostos de interesse na concentração de $200 \mu \mathrm{g} \mathrm{L}^{-1} \mathrm{e}$ $250 \mu \mathrm{L}$ do solvente de extração, com fator de concentração de 100 vezes. As condições testadas na microextração líquido-líquido para a análise de Benzeno, Tolueno, Etilbenzeno e Xilenos podem ser observadas na Tabela 2.

Tabela 2. Condições da microextração tipo líquido-líquido na análise de Benzeno, Tolueno, Etilbenzeno e Xilenos em água fortificada.

\begin{tabular}{|c|c|c|c|}
\hline Solvente & 1-octanol & 1-heptanol & Isoctano \\
\hline Condições & $\begin{array}{l}\text { Tempo: } 35 \text { minutos } \\
\text { Velocidade de agitação: } \\
700 \mathrm{rpm}\end{array}$ & $\begin{array}{l}\text { Tempo: } 35 \text { minutos } \\
\text { Velocidade de agitação: } \\
700 \mathrm{rpm}\end{array}$ & $\begin{array}{l}\quad 6 \text { tempos: } \\
\text { 15, 20, 25, 30, 35, } 40 \text { minutos } \\
\text { 4 velocidades de agitação: } \\
650,700,750,800 \mathrm{rpm}\end{array}$ \\
\hline
\end{tabular}

\section{RESULTADOS E DISCUSSÃO}

\subsection{Comparação entre as colunas cromatográficas}

A coluna HP-5, apesar de ser amplamente utilizada na análise de BTEX, não separou os isômeros meta e p-Xileno. Trabalhos mais recentes como o apresentado por Kelly e Harder (2003) mostram que a coluna Supelcowax ${ }^{\mathrm{TM}} 10$, de fase polar, separa os isômeros do Xileno e ainda possui a vantagem de ter um menor tempo de análise em comparação com o tempo obtido pela coluna apolar HP-5.

Em uma separação cromatográfica há duas propriedades principais responsáveis pelos tipos de interação: a pressão de vapor do soluto (na temperatura da coluna) e a interação físico-química do soluto com a fase estacionária. Quando a fase da coluna cromatográfica é 
apolar, a separação ocorre mais pelo fenômeno físico da pressão de vapor dos compostos de interesse do que propriamente pelo princípio de interação físico-química entre a fase estacionária da coluna cromatográfica e os compostos. Quando a coluna é polar há a presença de sítios ativos na fase estacionária o que potencializa o princípio de adsorção e, consequentemente, a interação dos analitos com a fase estacionária polar. Isto ocorre porque a composição química da fase estacionária afeta o processo de separação devido aos diferentes tipos de interação: dipolo-dipolo, dipolo-dipolo induzido, entre outros (Silva et al., 2005).

No caso dos BTEX, como as pressões de vapor para os Xilenos é a mesma para os isômeros para e meta, eles se separam melhor na coluna polar. Como o isômero orto tem pressão de vapor diferente da pressão de vapor dos isômeros meta e para, ele tem boa separação nas duas colunas.

A Tabela 3 mostra os tempos de retenção dos compostos BTEX na coluna HP-5 e na Suplecowax ${ }^{\mathrm{TM}} 10$, respectivamente.

Tabela 3. Tempos de retenção $\left(t_{r}\right)$ dos compostos BTEX na coluna HP-5 e na coluna Supelcowax ${ }^{\mathrm{TM}} 10$.

\begin{tabular}{l|cc}
\hline Composto & $\begin{array}{c}\text { HP-5 } \\
\mathbf{t}_{\mathbf{R}}(\mathbf{m i n u t o s})\end{array}$ & $\begin{array}{c}\text { Supelcowax } \\
\mathbf{t}_{\mathbf{R}}(\mathbf{m i n u t o s})\end{array}$ \\
\hline Benzeno & - & 3,75 \\
Tolueno & 3,43 & 4,86 \\
Etilbenzeno & 4,56 & 6,02 \\
o-Xileno & 4,96 & 6,96 \\
m-Xileno & 4,63 & 6,25 \\
p-Xileno & 4,64 & 6,15 \\
\hline
\end{tabular}

A Figura 1 mostra um cromatograma dos compostos BTEX analisados na coluna Supelcowax ${ }^{\mathrm{TM}} 10$, com seus respectivos tempo de retenção mostrando a separação adequada dos seis analitos de interesse.

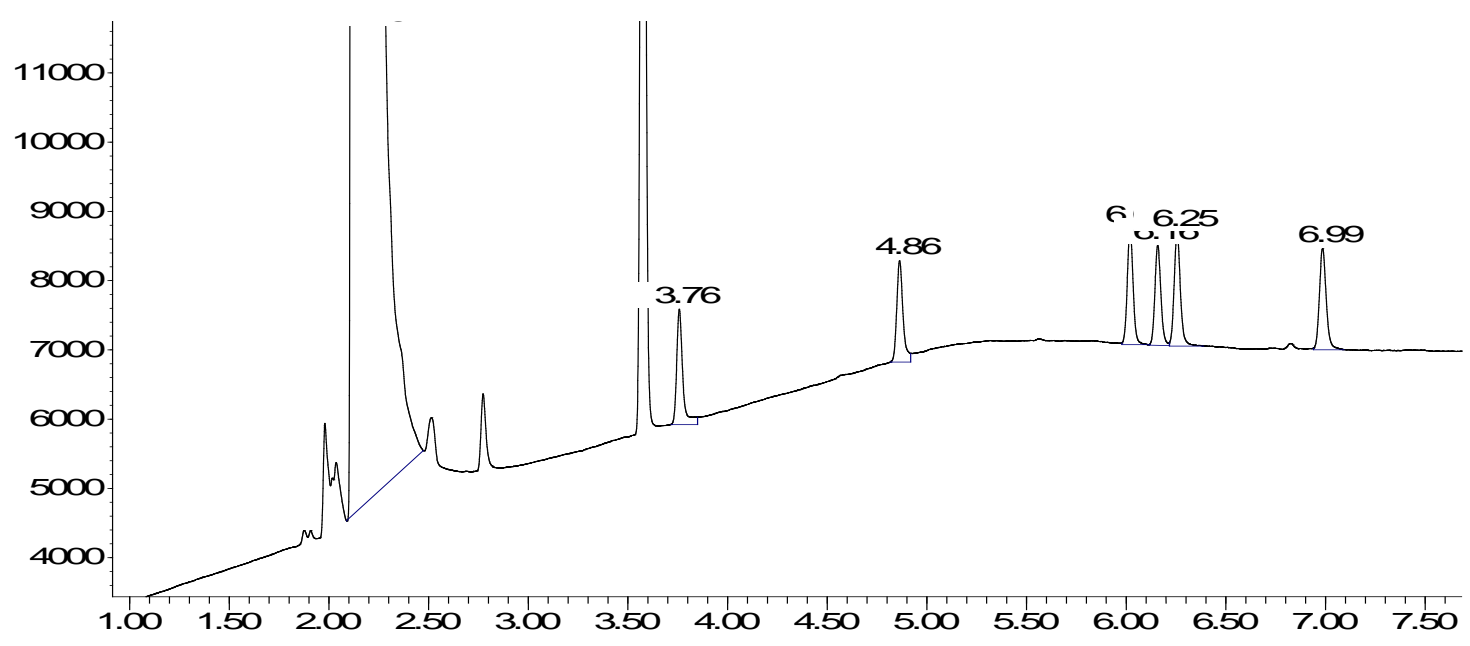

Figura 1. Cromatograma dos compostos Benzeno $(3,76)$, Tolueno $(4,86)$, Etilbenzeno $(6,02)$, o-Xileno $(6,99)$, m-Xileno $(6,25)$ e p-Xileno $(6,16)$ na coluna Supelcowax ${ }^{\text {TM }} 10$. 


\subsection{Metodologias de extração}

\subsubsection{Microextração Líquido-Líquido}

O solvente 1-octanol apresentou impurezas impossibilitando a sua utilização como solvente de extração. O solvente 1-heptanol, além de possuir uma impureza com tempo de retenção muito próximo ao analito o-Xileno, também mostrou que, por efeito de polaridade, os compostos que eluem da coluna mais próximos à eluição do solvente apresentam picos com resolução inadequada pela presença de "barriga" no cromatograma. O solvente isooctano foi o que apresentou melhores resultados de extração, com um cromatograma com picos bem resolvidos e bem definidos. Deste modo, este foi o solvente de extração escolhido.

Após a escolha do solvente de extração foram realizados testes para a escolha do melhor tempo de extração. O resultado obtido pode ser observado na Figura 2. Houve um aumento da eficiência de extração quando aumentado o tempo de extração em até 35 minutos. A partir deste tempo houve um decréscimo na eficiência de extração. Isso ocorreu por evaporação do solvente orgânico ou pela sua dissolução na fase aquosa (Sarafraz-Yazdi et al., 2009).

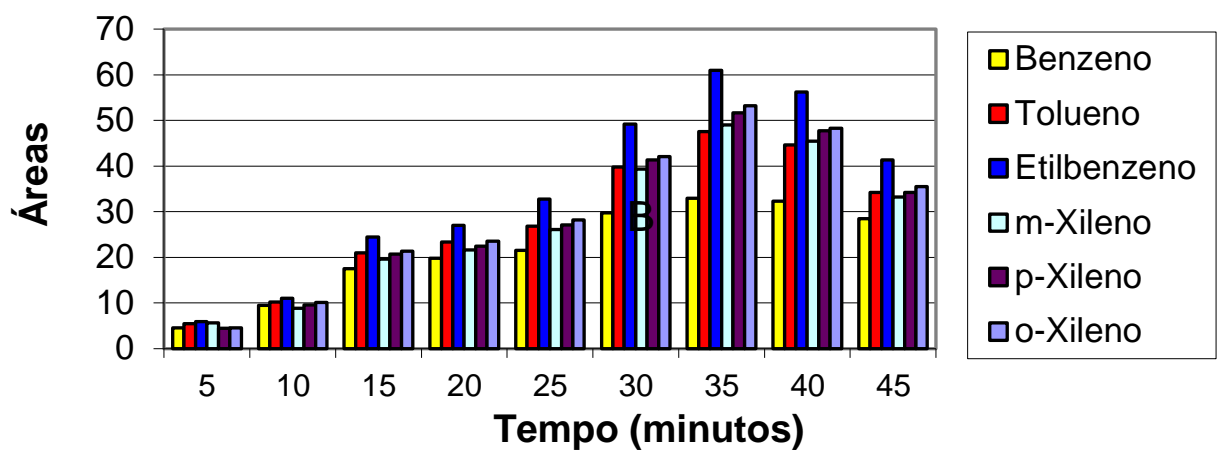

Figura 2. Área e Tempo de Extração para água fortificada com mistura dos analitos, concentração de $200 \mu \mathrm{g} \mathrm{L}^{-1}$, com velocidade de extração constante e fixa de $700 \mathrm{rpm}$.

Após a escolha do solvente e do melhor tempo de extração foram realizados testes para a escolha da melhor velocidade de extração. O resultado obtido pode ser observado na Figura 3. Houve um aumento da eficiência de extração quando aumentada a velocidade de agitação até um valor de $700 \mathrm{rpm}$. A partir desse valor houve um decréscimo na eficiência de extração devido a maior transferência dos analitos voláteis da fase líquida para fase gasosa.

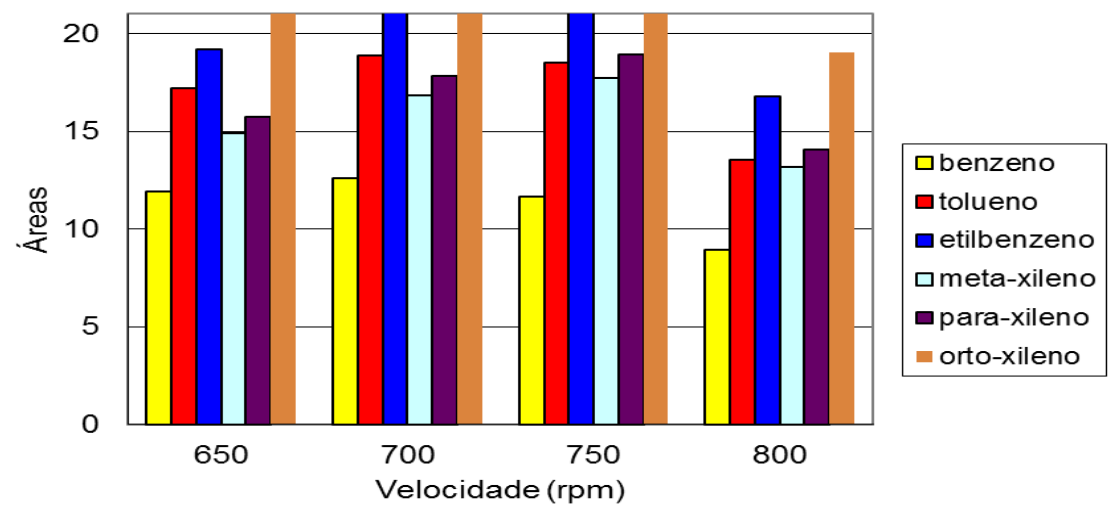

Figura 3. Área e velocidade de agitação para água Tipo1 fortificada com mistura dos analitos, concentração de $200 \mu \mathrm{g} \mathrm{L}^{-1}$, com tempo de extração de 35 minutos. 


\subsection{Validação das metodologias analíticas}

\subsubsection{Seletividade:}

A retenção relativa foi usada para identificação de substâncias e pode ser calculada para quaisquer picos no cromatograma, livre da restrição de serem adjacentes. Os valores de tempo de retenção $\left(t_{R}\right)$, tempo de retenção relativo $\left(t^{\prime}{ }_{R}\right)$ e fator de separação $(\alpha)$ dos seis analitos de interesse, podem ser observados na Tabela 4 .

Tabela 4. Coeficientes de seletividade para os compostos BTEX(s).

\begin{tabular}{l|ccc}
\hline Composto & $\mathbf{t}_{\mathbf{R}}$ & $\mathbf{t}_{\mathbf{R}}$ & $\boldsymbol{\alpha}$ \\
\hline Benzeno & 3,75 & 1,56 & 1,7 \\
Tolueno & 4,86 & 2,67 & 1,4 \\
Etilbenzeno & 6,02 & 3,83 & 1,2 \\
o-Xileno & 6,96 & 4,77 & 0,9 \\
m-Xileno & 6,25 & 4,06 & 1,0 \\
p-Xileno & 6,15 & 3,96 & 1,0 \\
\hline
\end{tabular}

\subsubsection{Faixa de trabalho:}

A faixa de trabalho de 10 a $50 \mu \mathrm{g} \mathrm{mL}^{-1}$ demonstrou-se adequada para construção das curvas analíticas, segundo os critérios de aceitabilidade da linearidade. Essa faixa de trabalho atende os limites de concentração máxima permitidos para cinco dos seis analitos de interesse.

\subsubsection{Linearidade:}

A utilização do método de regressão linear exige que algumas premissas sejam verdadeiras de modo a garantir que essa seja a melhor escolha do modelo matemático a ser utilizado para avaliação dos dados obtidos. Neste trabalho, as seguintes premissas foram avaliadas: valores extremos, normalidade, autocorrelação de resíduos, desvio de linearidade (falta de ajuste) e homogeneidade de variâncias.

Para detecção dos valores discrepantes foram utilizados os testes de Jack-Knife para um nível de significância estatística de 5\%. Para o Benzeno, dois valores extremos foram detectados e, como estavam causando desvios de linearidade foram rejeitados. Para os outros cinco compostos, um valor extremo foi detectado para cada um dos mesmos, com significância de $5 \%$ e $n=4$, como não causavam desvios de linearidade não foram rejeitados.

Para avaliar a normalidade dos resíduos foi utilizado o teste de Ryan-Joiner, que testa se os dados provêm ou não de uma distribuição normal. Após a retirada dos dois valores extremos para a construção da curva analítica do Benzeno, todos os seis compostos passaram nos testes de normalidade dos resíduos realizados com o teste de Ryan-Joiner, com significância de 5\%.

Para verificação da existência de autocorrelação dos resíduos foi utilizado o teste mais conhecido e empregado, o Durbin-Watson. Pelo teste verificou-se que não há autocorrelação dos resíduos em nenhum dos seis analitos de interesse, demonstrando assim, que o modelo de regressão linear pode ser utilizado.

Como última premissa verificada para a utilização do método dos mínimos quadrados foi verificada a homogeneicidade dos sistemas para cada um dos seis analitos de interesse, pelo teste de Levene. Para os seis analitos de interesse os valores de $\mathrm{p}$ encontrados foram maiores que 0,05 indicando que há homogeneicidade nos sistemas. 
Deste modo, as curvas analíticas dos seis analitos em questão foram construídas pelo método dos mínimos quadrados ordinários.

\subsubsection{Limite de Detecção:}

Foram calculados empregando-se o método baseado em parâmetros da curva analítica segundo Aragão et al. (2009). Neste método, o Limite de Detecção pode ser calculado a partir da Equação 1 e os valores obtidos estão apresentados a seguir.

$$
\mathrm{LD}=(3,3 \times \mathrm{s}) / \mathrm{a}
$$

em que:

S - é a estimativa do desvio padrão da resposta (que pode ser a estimativa do desvio padrão do branco, da equação da linha de regressão ou do coeficiente linear da equação); $\mathrm{e}$

a - é o coeficiente angular da curva analítica.

Foram obtidos os seguintes valores de Limite de Detecção (LD) para os analitos de interesse em $\mu \mathrm{g} \mathrm{mL}^{-1}$ : Benzeno, 2,74; Tolueno, 0,85; Etilbenzeno, 0,90; o-Xileno, 0,96; m-Xileno, 0,90 e p-Xileno, 0,88.

\subsubsection{Limite de Quantificação:}

Foram calculados empregando-se o método baseado em parâmetros da curva analítica segundo Aragão et al. (2009). Neste método, o Limite de Quantificação pode ser calculado a partir da Equação 2 e os valores obtidos estão a seguir:

$$
\mathrm{LQ}=(10 \times \mathrm{s}) / \mathrm{a}
$$

em que:

S - é a estimativa do desvio padrão da resposta (que pode ser a estimativa do desvio padrão do branco, da equação da linha de regressão ou do coeficiente linear da equação);e

a - é o coeficiente angular da curva analítica.

Foram obtidos os seguintes valores de Limite de Quantificação (LQ) para os analitos de interesse em $\mu \mathrm{g} \mathrm{mL}^{-1}$ : Benzeno, 8,29; Tolueno, 2,57; Etilbenzeno, 2,74; o-Xileno, 2,91; m-Xileno, 2,72 e p-Xileno, 2,66;

\subsubsection{Construção das Curvas Analíticas:}

A curva de quantificação foi elaborada utilizando o método de curva de extração construída com a extração de água Tipo 1 fortificada com os analitos de interesse nas concentrações de 0,$10 ; 0,20 ; 0,30 ; 0,40$ e $0,50 \mu \mathrm{g} . \mathrm{L}^{-1}$. $\mathrm{O}$ objetivo era de obter as seguintes concentrações finais nos extratos após a concentração de 100 vezes: $10 ; 20 ; 30 ; 40$ e $50 \mu$ g.L. ${ }^{-1}$.

\subsubsection{Recuperação:}

Para o estudo de recuperação foram fortificadas amostras de água Tipo1, com solução contendo todos os analitos de interesse, de modo que a solução final, após a extração, tivesse os analitos nas concentrações de $10 ; 30$ e $50 \mu \mathrm{g} \mathrm{L}^{-1}$. Quando a recuperação é obtida a partir de fortificações de matriz branca, o fator de recuperação $\left(f_{\text {rec }}\right)$ é calculado pela Equação 3 (Brasil, 2011a): 


$$
f_{\text {rec }}=\left[\left(\mathrm{C}_{\mathrm{f}}-\mathrm{C}_{\mathrm{nf}}\right) / \mathrm{C}_{\mathrm{ad}}\right] \times 100
$$

Os valores de percentual de Recuperação para os analitos de interesse podem ser observados na Tabela 5:

Tabela 5. Valores de Recuperação cientes para os compostos BTEX(s).

\begin{tabular}{|c|c|c|c|}
\hline Composto & $\begin{array}{c}\text { Recuperaçãa (\%) } \\
10 \mu \mathrm{g} . \mathrm{L}^{-1}\end{array}$ & $\begin{array}{c}\text { Recuperação (\%) } \\
\mathbf{3 0} \mu \mathrm{g} . \mathrm{L}^{-1}\end{array}$ & $\underset{50 \mu \mathrm{g} . \mathrm{L}^{-1}}{\operatorname{Recuperacão}}(\%)$ \\
\hline Benzeno & 78,3 & 90,2 & 97,2 \\
\hline Tolueno & 92,5 & 97,9 & 100,1 \\
\hline Etilbenzeno & 90,5 & 98,9 & 99,3 \\
\hline o-Xileno & 90,0 & 99,2 & 99,5 \\
\hline m-Xileno & 90,8 & 99,5 & 99,7 \\
\hline p-Xileno & 90,7 & 100,1 & 99,8 \\
\hline
\end{tabular}

Neste trabalho foi testado o efeito da adição de sal na eficiência da extração em amostras de água fortificada. Os resultados mostraram-se em concordância com Zanjani et al. (2007), indicando que a eficiência de extração dos compostos BTEX não se alterou pela adição de $\mathrm{NaCl}$ à amostra fortificada; por isso, as extrações foram realizadas na ausência do sal.

\section{CONCLUSÃO}

Neste trabalho foi desenvolvida e implementada uma nova metodologia para extração e determinação de resíduos de Benzeno, Tolueno, Etilbenzeno e Xilenos, em água de abastecimento público. Os limites de quantificação obtidos atendem aos valores máximos estabelecidos pela Norma de Potabilidade, do Ministério da Saúde (Portaria No 2914/2011), para cinco dos seis compostos estudados, ficando acima apenas para o benzeno.

A necessidade de um pequeno volume de amostra e de reagentes, e a não inclusão da etapa de evaporação do extrato permite um procedimento rápido, fácil e relativamente pouco oneroso, o que torna a metodologia estudada adequada às análises de rotina para controle da qualidade da água para consumo humano.

Tendo em vista que os analitos estudados são voláteis, o uso de uma técnica de extração que permite a concentração da amostra no próprio procedimento diminui as perdas durante o processo. A técnica de microextração líquido-líquido também reduz o limite de quantificação, pois, é possível pré concentrar as amostras em 100 vezes durante o processo de extração.

Mediante o uso de uma coluna com fase de separação polar (Supelcowax ${ }^{\mathrm{TM}} 10$ ), todos os compostos foram separados com resolução de separação adequada e curto tempo de análise, fato pouco reportado na literatura.

A coluna Supelcowax ${ }^{\mathrm{TM}} 10$ separa com resolução adequada todos os isômeros do Xileno, pois, estes isômeros interagem de forma diferente com a fase polar da coluna. A separação dos isômeros é importante porque existem modelos toxicocinéticos de exposição por inalação de Xileno em humanos que sugerem que há diferenças significativas entre a toxicidade, meia-vida, depuração e metabolismo entre as formas isoméricas dos Xilenos. Outros estudos indicam diferentes ordens de toxicidade relativa para os isômeros e as diferenças nos níveis de vigor, mesmo sendo pequenas. Assim, uma metodologia capaz de quantificar a separação dos isômeros posicionais do xileno pode ser interessante para diferenciar e entender melhor a exposição humana e ambiental ao m-Xileno e do p-Xileno. 
Os dados obtidos foram tratados estatisticamente com resultados satisfatórios em todos os testes realizados.

Em relação à validação da metodologia, todos os parâmetros de desempenho do método estudado apresentaram-se em concordância com o estabelecido pelos órgãos reguladores, INMETRO e ANVISA, demonstrando que a metodologia é adequada ao objetivo proposto.

\section{REFERÊNCIAS}

AGÊNCIA NACIONAL DE VIGILÂNCIA SANITÁRIA (ANVISA). Guia para qualidade em química analítica - uma assistência à habilitação. Brasília, DF, 2005.

ARAGÃO, N. M.; VElOSO, M. C. C.; ANDRADE, J. B. Validação de métodos cromatográficos de análise - um experimento de fácil aplicação utilizando cromatografia líquida de alta eficiência (CLAE) e os princípios da "química verde" na determinação de metilxantinas em bebidas. Química Nova, v. 32, n. 9, p. 2476-2481, 2009. http://dx.doi.org/10.1590/S0100-40422009000900043

ASSOCIAÇÃO BRASILEIRA DE NORMAS TÉCNICAS. NBR ISO/IEC 17.025. Requisitos gerais para competência de laboratórios de ensaio e calibração. Rio de Janeiro, 2005.

AUSTRALIA. National Health and Medical Research Council. Australian drinking water guidelines (ADWG). National water quality management strategy. Canberra, 2004. $511 \mathrm{p}$.

BRASIL. Ministério da Agricultura, Pecuária e Abastecimento. Guia de validação e controle de qualidade analítica (CGAL/SDDA). Fármacos em Produtos para Alimentação Animal e Medicamentos Veterinários. Brasília, 2011. 72p.

BRASIL. Ministério da Saúde. Portaria No 2914, de 12 de dezembro de 2011. Estabelece os procedimentos e responsabilidades relativos ao controle e vigilância da qualidade da água para consumo humano e seu padrão de potabilidade, e dá outras providências. Diário Oficial [da] União, Poder Executivo, de 14 de dezembro de 2011.

BRASIL. Ministério do Meio Ambiente. Conselho Nacional do Meio Ambiente (CONAMA). Resolução No. 357, de 17 de março de 2005. Dispõe sobre a classificação dos corpos de água e diretrizes ambientais para o seu enquadramento, bem como estabelece as condições e padrões de lançamento de efluentes, e dá outras providências. Diário Oficial [da] União, de 18 de março de 2005.

CANADA. Health Canada. Guidelines for canadian drinking water quality (GCDWQ). Supporting Document. $6^{\text {th }}$ Ed. Ontario, 1996. 90 p.

CORSEUIL, H. X.; MARINS, M. D. M. Contaminação de águas subterrâneas por derramamentos de gasolina: O problema é grave? Revista Engenharia Sanitária e Ambiental, v. 2, n. 2, p. 50-54, 1997.

EURACHEM. The fitness for purpose of analytical methods, a laboratory guide to method validation and related topics. Teddington: LGC, 1998. 61p.

EUROPEAN COMMUNITIES. Drectiva 98/83/EC. On the quality of water intended for human consumption. Official Journal of the European Communities, 5 dez. 1998. Disponível em: <http://ec.europa.eu> Acesso em: 26 fe.v 2014. 
GOBATO, E. A. A. F.; LANÇAS, F. M. Comparação entre injeção na coluna (on-column) e headspace dinâmico na determinação de Benzeno, Tolueno e Xilenos (BTX) em amostras de água. Química Nova, v. 24, n. 2, p. 176-179, 2001. http://dx.doi.org/10.1590/S0100-40422001000200004

GREEN, J. M. A practical guide to analytical method validation. Analytical Chemistry, v. 68, p. 305A-309A, 1996. http://dx.doi.org/10.1021/ac961912f

INSTITUTO NACIONAL DE METROLOGIA (INMETRO). DOQ-CGCRE-008 Orientações sobre validação de métodos de ensaios químicos. Brasília, 2003. 35 p.

KELLY, K.; HARDER, B. BTEX(s): Complete resolution in under 6.5 minutes. Environmental. The applications book, Torrance, Phenomenex p 1-2, April 2003.

LOURENÇO, M. Realização periódica de análises químicas de BTEX e PAH, em amostras de água e solo, nos postos de combustíveis. 2005. Disponível em: $<$ http://www.portaldepostos.com.br/paginas/gest.meioambiente.materia9.html $>$. Acesso em: 26 fev. 2014.

SARAFRAZ-YAZDI, A.; AMIRI, A. H.; ES'HAGHI, Z. Separation and determination of Benzene, Toluene, Ethybenzene and o-Xylene compounds in water using directly suspended droplet microextraction coupled with chromatography-flame ionization detector. Talanta, v. 78, p. 936-941, 2009. http://dx.doi.org/10.1016/j. talanta.2008.12.069

SILVA, D. D.; INNOCENTINI, A. P.; CHIERICE, G. O.; GALHIANE, M. S.; SANTOS, L. S. Avaliação da seletividade de uma nova coluna capilar em cromatografia gasosa teste de Grob e índice de retenção. Revista Analytica, n. 17, p. 40-47, 2005.

SILVA, R. L. B. Contaminação de poços rasos no bairro Brisamar, Itaguai, RJ, por derramamento de gasolina: concentração de $\operatorname{BTEX}(\mathrm{s})$ e avaliação da qualidade da água consumida pela população. 2002. Tese (Doutorado) - Escola Nacional de Saúde Pública Sergio Arouca, Fundação Oswaldo Cruz, Rio de Janeiro, 2002.

SILVA, R. L. B.; BARRA, C. M.; MONTEIRO, T. C. N.; BRILHANTE, O. M. Estudo da contaminação de poços rasos por combustíveis orgânicos e possíveis consequências para a saúde pública no Município de Itaguaí, Rio de Janeiro, Brasil. Cadernos de Saúde Pública, v. 18, n. 6, p. 1599-1607, nov./dez., 2002. http://dx.doi.org/10.1590/ S0102-311X2002000600014

UNITED STATES. Environmental Protection Agency (USEPA). List of Contaminants \& their Maximum Contaminant Level (MCLs) in drinking water. Washington (DC), 2004.

WORLD HEALTH ORGANIZATION (WHO). Air quality guidelines. Second Edition, Chapter 5. 2. Benzene. Copenhagen, Denmark, 2000a.

WORLD HEALTH ORGANIZATION (WHO). Air quality guidelines. Second Edition, Chapter 5. 14. Toluene. Copenhagen, Denmark, $2000 \mathrm{~b}$.

WORLD HEALTH ORGANIZATION (WHO). Guidelines for drinking-water quality. Ethylbenzene in Drinking-Water. Second Edition, Vol. 2. Health Criteria and other Supporting Information. Geneva, 1996a. 
WORLD HEALTH ORGANIZATION (WHO). Guidelines for drinking-water quality. Benzene in Drinking-Water. Second Edition, Vol. 2. Health Criteria and other Supporting Information. Geneva, $1996 \mathrm{~b}$.

WORLD HEALTH ORGANIZATION (WHO). Guidelines for drinking-water quality. Toluene in Drinking-Water. Second Edition, Vol. 2. Health Criteria and other Supporting Information. Geneva, 2004.

ZANJANI, M. R. K.; YAMINI, Y.; SHARIATI, S.; JONSSON J. A. A new liquid-phase microextraction method based on solidification of floating organic drop. Analytica Chimica Acta, v. 585, p. 286-293, 2007. http://dx.doi.org/10.1016/j.aca.2006.12.049 


Ambiente \& Água - An Interdisciplinary Journal of Applied Science
ISSN 1980-993X - doi:10.4136/1980-993X
www.ambi-agua.net
E-mail: ambi-agua@agro.unitau.br

\title{
Parámetros del modelo de infiltración de Horton obtenidos mediante el uso de un simulador de lluvia, Córdoba, Argentina
}

\author{
doi: 10.4136/ambi-agua.1320 \\ Received: 18 Feb. 2014; Accepted: 08 Mar 2014 \\ Juan Francisco Weber \\ Universidad Tecnológica Nacional, Córdoba, Argentina \\ Departamento de Ingeniería Civil \\ Autor correspondiente: e-mail: jweber@civil.frc.utn.edu.ar
}

\section{RESUMEN}

Se presentan los resultados obtenidos del ajuste de los parámetros del modelo de infiltración de Horton, a partir de los datos experimentales recopilados en una campaña de medición in situ de la capacidad de infiltración en distintos sitios de la ciudad de Córdoba (Argentina). Como instrumento se utilizó un microsimulador de lluvia portátil diseñado y construido en el Laboratorio de Hidráulica, UTN-Facultad Córdoba. Este equipo, que es completamente desarmable y define una parcela de ensayo de $1 \mathrm{~m}^{2}$, permite generar lluvias de intensidades comprendidas entre los 65 y $120 \mathrm{~mm} / \mathrm{h}$. La selección de los sitios de ensayo respondió a dos condiciones: el tipo y el uso del suelo. A su vez, se consideraron distintas condiciones de humedad inicial. Los valores medidos fueron digitalizados y procesados, construyéndose las curvas de infiltración acumulada y tasa de infiltración en función del tiempo. A partir de estos valores, se ajustaron los parámetros del modelo de Horton. Los parámetros así obtenidos, que superan en calidad a los determinados en campañas anteriores utilizando la técnica del infiltrómetro de doble anillo, serán de utilidad en tareas de diseño hidrológico urbano, y representan un aporte original al conocimiento de la respuesta hidrológica de los suelos urbanos de Córdoba. La propuesta podrá repetirse en otros sitios ampliando de esa forma su significación científica.

Palabras-clave: hidrología experimental, mediciones hidrológicas, hidrología urbana.

\section{Parâmetros do modelo de infiltração de Horton desenvolvidos utilizando-se um simulador de chuva, Córdoba, Argentina}

\section{RESUMO}

Neste artigo são apresentados resultados do ajuste dos parâmetros do modelo de infiltração de Horton para vários locais na cidade de Córdoba (Argentina), com dados experimentais obtidos em uma campanha de medição de campo da capacidade de infiltração, em que foi utilizado um simulador de chuva portátil, projetado e construído no Laboratório de Hidráulica, UTN - Facultad Córdoba. Esse equipamento, que é completamente desmontável e define um plano de teste de $1 \mathrm{~m}^{2}$, pode gerar intensidades de precipitação que variam entre 65 e $120 \mathrm{~mm} / \mathrm{h}$. A seleção dos locais para obtenção das amostras experimentais foi relacionada a duas condições: o tipo e o uso do solo, tendo sido considerada a condição inicial de umidade do local. Os valores medidos foram digitalizados e processados, e traçadas as curvas de infiltração cumulativa e taxa de infiltração. A partir desses valores obtidos experimentalmente foram ajustados os parâmetros do modelo de Horton. E os 
resultados finais mostraram que os parâmetros obtidos mostraram-se melhor ajustados do que aqueles determinados com o uso da técnica do infiltrômetro duplo, apresentando assim, melhor utilidade para trabalhos de hidrologia urbana para solos urbanos da cidade de Córdoba, e a sua repetição para outros locais poderá ampliar o significado científico da proposta.

Palavras-chave: hidrologia experimental, medições hidrológicas, hidrologia urbana.

\title{
Parameters of Horton's infiltration model obtained through the use of a rainfall simulator, Córdoba, Argentina
}

\begin{abstract}
This study presents the results of a parameter fit of the Horton infiltration model at various sites in the city of Córdoba, Argentina. The work is based upon experimental data collected in field measurements of infiltration capacity. The study employed a portable rainfall simulator that was designed and built at the Hydraulics Laboratory, UTN - Facultad Córdoba. This equipment, which is completely detachable and defines a test plot of $1 \mathrm{~m}^{2}$, can generate rainfall intensities which vary between 65 and $120 \mathrm{~mm} / \mathrm{h}$. Test site selection depended upon soil type and land use. Additionally, different initial moisture conditions were considered. The measured values were digitized and processed, and cumulative infiltration and infiltration rate curves were plotted. From these values, the parameters of Horton's model were adjusted. The quality of these parameters exceeded those of previous studies that used the double ring infiltrometer technique, and will be useful in urban hydrology design works. They represent an original contribution to knowledge of the hydrological response of urban soils in Córdoba. The proposal may be repeated elsewhere in order to expand its scientific significance.
\end{abstract}

Keywords: experimental hydrology, hydrological measurements, urban hydrology.

\section{INTRODUCCIÓN}

En trabajos ingenieriles vinculados al diseño y cálculo de obras de desagüe pluvial urbano, el proyectista se ve en la obligación, a la hora de cuantificar los caudales de aporte, a considerar dos tipos de superficies en las cuencas: las impermeables y las permeables. Las primeras, sin duda provocan un alto impacto en el volumen de crecidas y una disminución del tiempo de respuesta de la cuenca (Tucci, 2001). En cuanto a las segundas, se han impuesto en la práctica un conjunto de modelos de uso generalizado a la hora de cuantificar la fracción de la precipitación de escurrimiento directo, y por tanto, la fracción infiltrada; estos modelos, de carácter conceptual (Ravi y Williams, 1998), intentan simplificar el abordaje riguroso del problema, representado por la ecuación de Richards (Chow et al., 1994), y por tanto son los utilizados más ampliamente en la práctica hidrológica.

Una de las principales dificultades que encuentra el modelador a la hora de aplicar estos modelos de infiltración es la de estimar los parámetros de los mismos, tratando de lograr una adecuada representación de la realidad. Lamentablemente, existen grandes dificultades a la hora de disponer de datos medidos de infiltración en áreas permeables urbanas en la República Argentina. En la ciudad de Córdoba, por ejemplo, recién se encara una tarea sistemática de producción de información experimental al respecto a partir del trabajo de Weber et al. (2005), a través una campaña de obtención de datos experimentales de infiltración en suelos de la ciudad de Córdoba, mediante la técnica del infiltrómetro de doble anillo. Este procedimiento de ensayo permite obtener mediciones directas de infiltración en áreas reducidas (puntuales). Son conocidas las severas limitaciones que presentan las mediciones así determinadas, fundamentalmente en relación a la falta de representatividad del proceso lluvioso en la técnica de ensayo, por un lado, y a la fuerte alteración de la superficie 
del terreno debido al hincado de los anillos; estas limitaciones conllevan a errores experimentales difíciles de cuantificar.

Con el objetivo de obtener una caracterización experimental más verosímil del proceso hidrológico de la infiltración, se propuso utilizar como instrumento de ensayo un simulador de lluvia portátil de desarrollo propio; se esperarían como beneficios inmediatos: una mejor simulación del proceso lluvia - infiltración (debido a su mayor similitud con el proceso real), y una menor alteración de la parcela de ensayo; es decir, se intenta subsanar las limitaciones del procedimiento del infiltrómetro de doble anillo anteriormente utilizado.

\section{MATERIALES Y MÉTODOS}

\subsection{El simulador de lluvia}

Los simuladores de lluvia son instrumentos de investigación diseñados para aplicar agua de forma similar a los episodios tormentosos naturales. Son útiles para obtener datos de erosión, infiltración, escorrentía superficial y transporte de sedimentos. No obstante, las características de la lluvia natural deben ser simuladas de forma adecuada, los datos obtenidos deben ser analizados cuidadosamente y se debe efectuar una buena interpretación de los resultados para obtener información fiable en las condiciones para las que ha sido aplicable la lluvia (Benito et al., 2003).

Uno de los antecedentes de mayor peso en el diseño del simulador de lluvia utilizado fue el precedente local de un instrumento diseñado por Irurtia y Mon (1994); a partir de un modelo de Kamphorst (1987). Este microsimulador de lluvia fue luego modificado por Aoki y Sereno (1999), y se encuentra actualmente en uso en la Facultad de Agronomía de la Universidad Nacional de Córdoba.

El formador utilizado se compone de una aguja hipodérmica introducida en tubo rígido, el cual se obtiene de cortar su propio estuche, al ras de dicha aguja. Los formadores ensayados correspondieron a un mismo diámetro de la aguja, $0.8 \mathrm{~mm}$, y tres longitudes diferentes, $25.4 \mathrm{~mm}, 38.1 \mathrm{~mm}, 50.8 \mathrm{~mm}$, las que corresponden a $1,1 \frac{1}{2}$ y 2 pulgadas respectivamente.

Se realizó una serie de mediciones de laboratorio para determinar el comportamiento hidráulico de estos formadores. En base a esta información se decidió colocar un total de 289 formadores, distribuidos en 17 filas por 17 columnas, y separados a una distancia de 5,30 cm entre ejes, cubriendo de esta manera cada formador, un área aproximada de $28,10 \mathrm{~cm}^{2}$ sobre la base de una batea de $96 \mathrm{~cm} \times 96 \mathrm{~cm}$ de lado. El tipo de formador seleccionado fue el $\mathrm{N}^{\mathrm{o}} 3$, correspondiente a la aguja de 2 pulgadas, ya que fue el que presentó las menores intensidades.

El equipo (Figura 1) consta básicamente de una estructura metálica, de caño de acero de sección cuadrada, formando un prisma cuadrado de $2 \mathrm{~m}$ de altura y $1 \mathrm{~m}$ de lado. Este prisma se forma a través de cuatro columnas y cerrado por medio de cortinas rompevientos. Las columnas sostienen el sistema de alimentación de agua que está compuesto por dos tanques; uno de alimentación, solamente y el otro de alimentación y regulación de intensidad.

La regulación de la intensidad se produce a través de un flotante (Achutegui et al., 1996). Debajo del sistema de alimentación de agua se encuentra la batea con los 289 formadores de gotas, que producen la lluvia simulada. La base de este prisma está constituida por un marco cuadrado de hierro, de $1 \mathrm{~m}$ de lado y $0.10 \mathrm{~m}$ de altura, con vertederos en sus cuatro lados y canales para el transporte del agua escurrida. Este marco de hierro, en su posición de trabajo es hincado en el suelo, constituyendo así las paredes límites de la parcela de medición. El peso total del equipo armado es de $110.60 \mathrm{~kg}$; el peso del fluido puede llegar hasta los $100 \mathrm{~kg}$. 


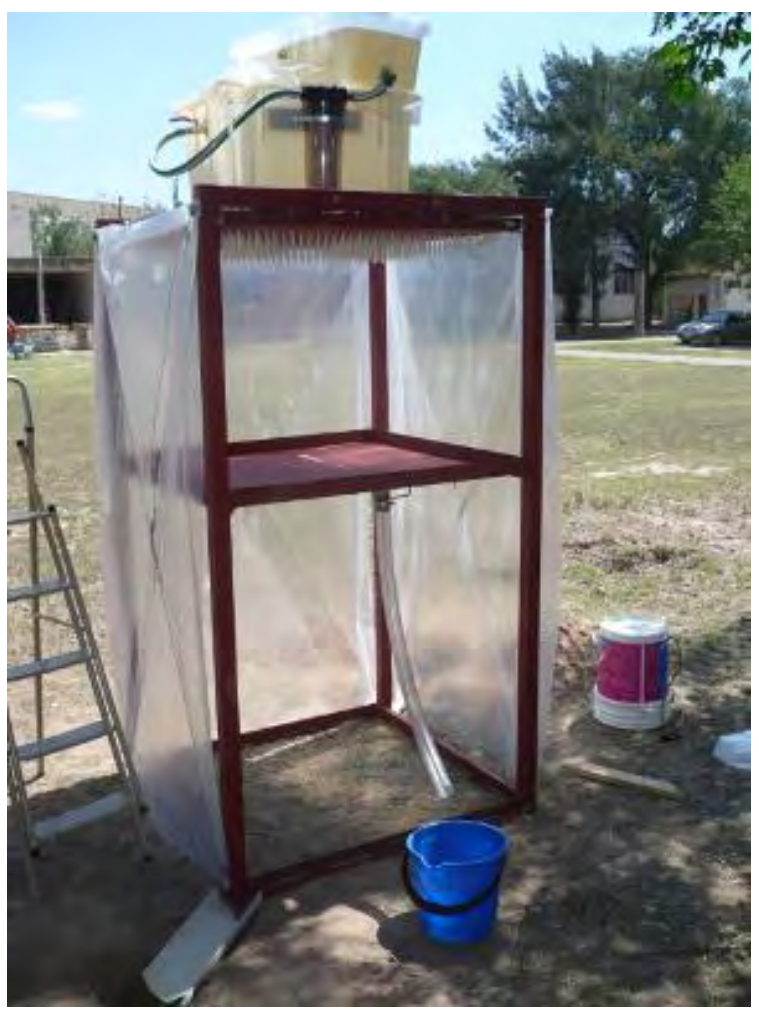

Figura 1. Simulador de lluvia en campaña.

\subsection{Tareas de calibración}

Para la calibración se utilizaron cinco probetas graduadas de $1000 \mathrm{ml}$, con divisiones de $10 \mathrm{ml}$ cada una. En su parte superior se les colocó un embudo de $32 \mathrm{~cm}$ de diámetro exterior y $31 \mathrm{~cm}$ de diámetro interior, funcionando el conjunto como un pluviómetro. Se midió el tiempo que tardó en llenarse un volumen fijo de $850 \mathrm{ml}$ en cada pluviómetro para las diferentes cargas estudiadas. Estas fueron $11 \mathrm{~cm}, 13 \mathrm{~cm}, 15 \mathrm{~cm}, 17,5 \mathrm{~cm}, 20 \mathrm{~cm}, 22,5 \mathrm{~cm}$ y $25 \mathrm{~cm}$.

Cada uno de los puntos fue medido simultáneamente durante un funcionamiento continuo del simulador de lluvia de aproximadamente $2 \mathrm{~h}$ por ensayo, obteniéndose de esta manera 10 datos por pluviómetro, y una muestra total de 50 datos para cada carga analizada. Esto representa un total de 350 datos obtenidos. Los resultados de estas mediciones debieron ser corregidos por el error sistemático introducido en el posicionamiento de los pluviómetros, que produjo que el número de formadores capturados variara entre 23 y 25.

Se verificó la normalidad de la distribución de las observaciones, estandarizando cada serie. Con los valores medios de intensidad obtenidos para cada carga, se trazó la curva de ajuste indicada en la Figura 2. En esta figura, las curvas que rodean a la regresión potencial corresponden a bandas de $99 \%$ y $90 \%$ de certidumbre, respectivamente, con un coeficiente de determinación $\mathrm{R}^{2}=0.997$ de acuerdo con la Ecuación 1 .

$$
i=15,15 h^{0.63}
$$

en que:

$i$ - es la intensidad de lluvia producida (en $\mathrm{mm} / \mathrm{h}$ ) y

$h$ - es la carga (en cm) sobre los formadores.

Del análisis estadístico de los datos, se pudo concluir que los valores de intensidad obtenidos a partir de la Ecuación 1 tienen una incertidumbre asociada de $3 \mathrm{~mm} / \mathrm{h}$, lo cual representa un error de entre el 3 y el $5 \%$ de la intensidad producida. 


\subsection{Trabajos experimentales}

Para la definición de los sitios de ensayo se consideró que las dos variables a priori más influyentes sobre los resultados a obtener eran el tipo de suelo y el uso del suelo (Weber et al., 2005). Con respecto al tipo, más que a una clasificación geotécnica se asumió que una clasificación de características regionales resultaría con mayor representatividad hidrológica. Para ello, se fijó como criterio la clasificación de ambientes geomorfológicos desarrollada por Quintana Salvat y Barbeito (1994). Este trabajo detectó básicamente dos ambientes diferenciados en el ejido de la ciudad de Córdoba: la planicie loessoide (correspondiente a un suelo del tipo limo arenoso, de gran cohesión en condiciones de baja humedad) y la terraza de inundación del antiguo cauce del río Suquía (Primero), la cual fue a su vez clasificada por los autores citados en tres subambientes: terraza baja, media y alta, según su cercanía al actual cauce del río que atraviesa la ciudad.

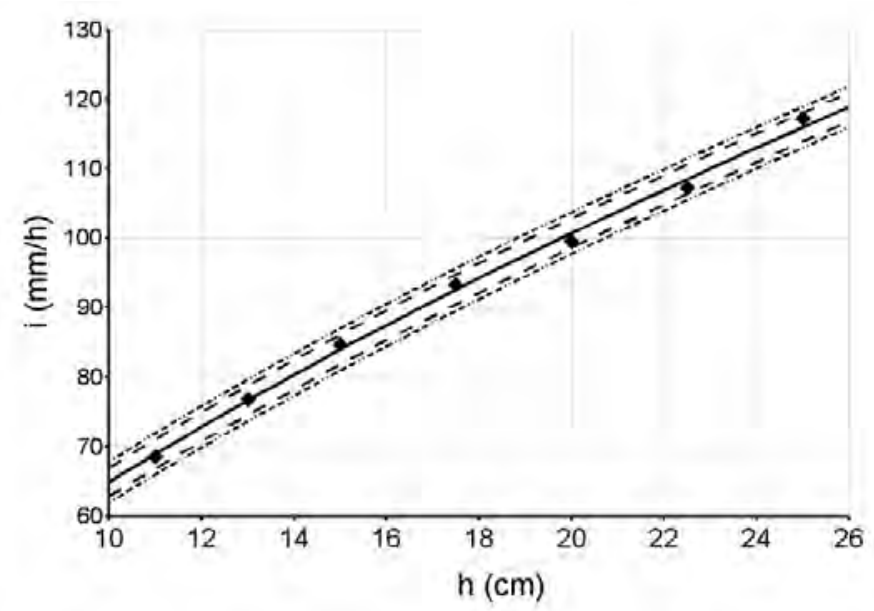

Figura 2. Curva de calibración del simulador de lluvia.

En cuanto al uso del suelo, se distinguió básicamente en tres tipos fundamentales: los patios y jardines de viviendas residenciales (espacios verdes con bajo tránsito), las plazas, parques y paseos públicos (espacios verdes con medio tránsito), y finalmente las calles no pavimentadas (calles de tierra). El principal criterio de selección se basó en la intensidad del tránsito, tanto peatonal como vehicular, debido a su impacto directo en la capacidad del infiltración del suelo. Además, se agregó como punto de interés especial el lecho de una laguna de detención en la zona norte de la ciudad.

El Cuadro 1 muestra los sitios de ensayo seleccionados clasificados según el uso del suelo y el ambiente geomorfológico. Como puede verse, no fue posible conseguir terreno disponible para realizar el ensayo correspondiente a espacios verdes de bajo tránsito en la terraza media del río Suquía, debido a que este ambiente cubre un área relativamente pequeña y fuertemente urbanizada de la ciudad. En total se ensayaron 12 sitios a lo largo del ejido urbano de la ciudad.

En cada uno de los sitios seleccionados se realizaron tres ensayos con el simulador de lluvia, bajo intensidades relativamente constantes (del orden de los $70 \mathrm{~mm} / \mathrm{h}$ ) con diferentes condiciones iniciales de humedad, las cuales fueron obtenidas o bien por las condiciones climáticas imperantes o bien los terrenos fueron humedecidos (regados) previamente a partir de condiciones secas. Además, en la mayoría de los sitios se realizó simultáneamente el ensayo clásico de infiltración mediante el infiltrómetro de doble anillo, como control y contraste de las mediciones efectuadas. La campaña de medición se extendió durante siete meses e implicó el trabajo de tres personas en forma simultánea, realizando entre dos y tres ensayos por semana. 
Cuadro 1. Sitios de ensayo.

\begin{tabular}{|c|c|c|c|}
\hline \multirow{2}{*}{$\begin{array}{l}\text { Tipo de suelo } \\
\text { (ambiente } \\
\text { geomorfológico) }\end{array}$} & \multicolumn{3}{|c|}{ Uso del suelo } \\
\hline & $\begin{array}{l}\text { Espacios verdes } \\
\text { (bajo tránsito) }\end{array}$ & $\begin{array}{l}\text { Espacios verdes } \\
\text { (medio tránsito) }\end{array}$ & $\begin{array}{c}\text { Calles no pavimentadas (alto } \\
\text { tránsito) }\end{array}$ \\
\hline Terraza alta & ITS Villada & ITS Villada & ITS Villada \\
\hline Terraza media & & Parque General Paz & $\begin{array}{l}\text { Justo Liebig } 5940-\mathrm{B}^{\circ} \text { Villa } \\
\text { Belgrano }\end{array}$ \\
\hline Terraza baja & Torres de $\mathrm{B}^{\mathrm{o}}$ Junior & $\begin{array}{l}\text { Parque de las } \\
\text { Naciones }\end{array}$ & $\begin{array}{l}\text { Carlos Gauss } 4619-\mathrm{B}^{\circ} \\
\text { Villa Belgrano }\end{array}$ \\
\hline $\begin{array}{l}\text { Planicie } \\
\text { loessoide }\end{array}$ & $\begin{array}{l}\text { L. Suárez de } \\
\text { Figueroa }-\mathrm{B}^{\mathrm{o}} \mathrm{M} \text {. de } \\
\text { Sobremonte }\end{array}$ & $\begin{array}{l}\text { parque UTN } \\
\text { Laguna de detención }\end{array}$ & $\begin{array}{l}\text { Hugo Miatello } 4600-\mathrm{B}^{\circ} \\
\text { Poeta Lugones }\end{array}$ \\
\hline
\end{tabular}

La duración de los ensayos fue variable, comprendida en general entre 1.5 y $2 \mathrm{~h}$, dependiendo del comportamiento observado in situ del proceso de infiltración, en cuanto a la velocidad con que se alcanzó la condición de régimen. El número y frecuencia de las observaciones también fue dependiente de las condiciones locales encontradas, observándose una menor frecuencia de medición en el simulador (y por tanto, una mayor frecuencia en el infiltrómetro) en los suelos de mayor capacidad de infiltración. Para facilitar la tarea de medición, se seleccionó en cada caso el volumen de registro, el cual varió desde 50 hasta $500 \mathrm{~cm}^{3}$.

Por otro lado, en todos los casos se midió la tasa de captura de las cortinas laterales, la cual fue considerada en el balance hidrológico a la hora del procesamiento de la información.

Antes del inicio de cada ensayo, se extrajeron muestras de suelo para la determinación del contenido de humedad antecedente. El contenido de humedad fue determinado gravimétricamente, a través de la extracción de muestras de suelo a $10 \mathrm{~cm}$ de profundidad, secándolas en estufa a $110^{\circ} \mathrm{C}$ y pesando la muestra seca. Para relacionar esta humedad gravimétrica con la humedad volumétrica $\theta$ se utilizó la densidad (peso unitario) del suelo. Este valor fue estimado a partir de las observaciones in situ realizadas en tareas anteriores en cada uno de los ambientes geomorfológicos descriptos (Weber et al., 2005).

Los datos así obtenidos fueron procesados utilizando la planilla de cálculo Microsoft Excel, que permitió no sólo la representación gráfica de la información recopilada, sino también las tareas de ajuste de parámetros que se describirán posteriormente. 


\subsection{El modelo de Horton}

Horton (1939) propuso, en base a numerosas observaciones experimentales, las Ecuaciones 2 y 3 para estimar la tasa de infiltración y la infiltración acumulada.

$$
\begin{aligned}
& f(t)=f_{b}+\left(f_{0}-f_{b}\right) e^{-k t} \\
& F(t)=f_{b} t+\frac{f_{0}-f_{b}}{k}\left(1-e^{-k t}\right)
\end{aligned}
$$

en que corresponde a un modelo de tres parámetros:

$$
\begin{aligned}
& f_{b}, f_{0} \text { y } k \text {, donde } \\
& f_{b} \text { - es la tasa base de infiltración (capacidad mínima de infiltración), } \\
& f_{0} \text { - es la tasa inicial de infiltración y } \\
& k \text { - un parámetro de forma. }
\end{aligned}
$$

En base a la información recopilada en campaña, se realizó el ajuste de los parámetros de este modelo, buscando la minimización de la función objetivo F.O. representada por la suma de las desviaciones cuadráticas entre los n valores de infiltración acumulada observados $\left(F_{i}\right)$ y calculados $\left(F_{i}^{c}\right)$, para cada sitio de ensayo y cada condición inicial de humedad, de acuerdo con la Ecuación 4.

$$
\text { F.O. }=\sum_{i=1}^{n}\left(F_{i}-F_{i}^{c}\right)^{2}
$$

El proceso se automatizó mediante un código especialmente desarrollado en GNU Octave (Eaton et al., 2007) que permitió ajustar para cada uno de los 34 archivos de datos, los parámetros óptimos del modelo de Horton a través del algoritmo de optimización multidimensional no restringida de Nelder-Mead (Mathews y Fink, 2004).

\section{RESULTADOS Y DISCUSIÓN}

De este modo se obtuvieron 34 juegos de parámetros, junto con el valor del coeficiente de determinación $\mathrm{R}^{2}$, el cual es una medida del grado de ajuste alcanzado. En la Tabla 1 se presentan los parámetros así ajustados. En esa tabla puede apreciarse que a pesar de haberse implementado una optimización no restringida, en todos los casos los parámetros obtenidos cumplen la condición $f_{0}>f_{b}$. Pueden observarse, además, los valores relativamente altos del coeficiente de determinación $\mathrm{R}^{2}$. Este estadístico tomó valores comprendidos entre $0.9950 \mathrm{y}$ 0.9999, con una media de 0.9990. Su significancia estadística es muy alta, pudiendo no rechazarse la hipótesis nula aún para valores de $\alpha$ tan bajos como $1 \cdot 10^{-115}$ (esto debido principalmente al elevado número de grados de libertad, 173 en promedio).

En la Tabla 2 se indican los valores promedio (y el rango de variación) para los parámetros del modelo de Horton, clasificados según el uso del suelo. Puede observarse un rango bastante amplio de valores para los tres parámetros.

En la Figura 3 se presenta, a título de ejemplo, la infiltración acumulada medida en un ensayo en particular ( $2^{\circ}$ medición - Marqués de Sobremonte) junto con los valores predichos por el modelo de Horton. 
En la Figura 4 puede verse la correspondencia entre los valores observados y predichos por el modelo de Horton de infiltración acumulada; la recta de regresión de acuerdo con la Ecuación 5 entre estos conjuntos de datos (5898 puntos) es:

$$
F_{c}=1.001245 F_{m}-0.035053
$$

en que:

$F_{c}$ - es la infiltración acumulada calculada por Horton y

$F_{m}$ - la observada.

Puede verse la proximidad de esta recta a la identidad $(\mathrm{Fc}=\mathrm{Fm})$, correspondiente al ajuste perfecto. El valor medio de los errores $F_{c}-F_{m}$ resultó en $-0.0056 \mathrm{~mm}$; mientras que el valor medio del valor absoluto de estos errores es de $0.25 \mathrm{~mm}$, con un máximo de $1.85 \mathrm{~mm}$.

Los mayores errores porcentuales en la estimación de la infiltración ocurren (con un máximo del 52.6\%) para valores bajos de infiltración, correspondientes a los primeros instantes del ensayo, tendiendo a disminuir en valor absoluto a medida que transcurre el mismo, tal como se observa en la Figura 5, donde se representa el conjunto completo de observaciones realizadas. El error (en valor absoluto) porcentual promedio en la estimación por Horton resultó en $1.9 \%$.

Se analizó la posible correlación entre los parámetros ajustados del modelo. Se observó que los parámetros $f_{0}$ y $k$ presentaron cierta correlación $\left(\mathrm{R}^{2}=0.794\right)$ tal como había sido observado por Weber et al. (2005) a partir de mediciones realizadas con infiltrómetros de doble anillo. En la Figura 6 se observa un gráfico de dispersión entre estas dos variables, junto con la recta de regresión de acuerdo con la Ecuación 6 , cuya expresión es:

$$
f_{0}(\mathrm{~mm} / \mathrm{h})=37.6+3.36 k(1 / h)
$$

Es posible sustituir el valor de $f_{0}$ en la Ecuación 3 por el dado en la Ecuación 6, transformando de este modo al modelo en biparamétrico. Esta sustitución da lugar a un incremento en los errores de estimación. El valor medio de estos errores resultó en $0.2 \mathrm{~mm}$; mientras que el valor medio del valor absoluto de estos errores es de $1.9 \mathrm{~mm}$, con un máximo de $8.6 \mathrm{~mm}$. Los valores porcentuales correspondientes a los dos últimos resultaron, respectivamente, $11.9 \%$ y 129\%. En ausencia de otra información, la Ecuación 6 puede ser utilizada, en el área de estudio, para obtener una estimación de $f_{0}$ a partir de $k$ (o viceversa).

Por otra parte es de tener presente que la intensidad de la propia lluvia generada tiene un error de $\pm 3 \mathrm{~mm} / \mathrm{h}$ (Weber et al., 2010). Esto implica que para una duración típica del ensayo de $1.5 \mathrm{~h}$, este valor se transforma en una incertidumbre de $\pm 4.5 \mathrm{~mm}$ en la medición de la infiltración acumulada, muy superior en general a los errores asociados al uso de la Ecuación 6. Esto puede observarse a título de ejemplo en la Figura 7, donde se representa la infiltración acumulada medida (línea negra continua) junto con sus bandas de incertidumbre (líneas de trazo), superpuestas a las infiltraciones predichas por el modelo de Horton con sus tres parámetros (puntos rojos) o con la sustitución de la Ecuación 6 (puntos azules), para un ensayo en particular ( $2^{\circ}$ medición - casa $\mathrm{B}^{\mathbf{o}}$ Marqués de Sobremonte). 
Tabla 1. Parámetros ajustados del modelo de Horton $\left(f_{o}\right.$ y $f_{b}$ en $\mathrm{mm} / \mathrm{h}, k$ en $\left.1 / \mathrm{h}\right)$.

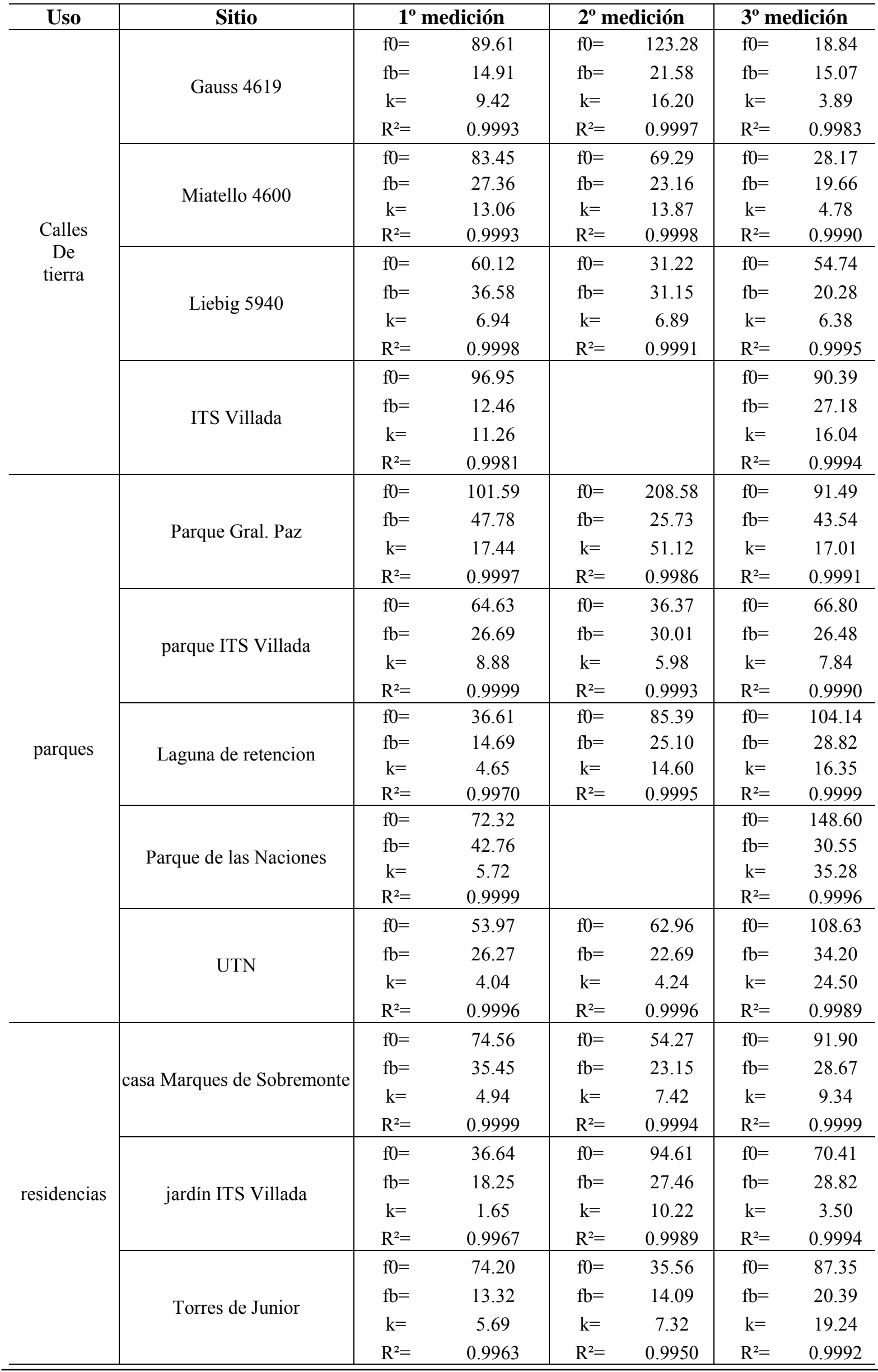


Tabla 2. Valores medios de los parámetros de Green \& Ampt y su rango de variación (entre paréntesis) según el uso del suelo

\begin{tabular}{c|lc|lc|lc}
\hline parámetros & \multicolumn{2}{|c|}{ Calles } & \multicolumn{2}{|c|}{ Parques } & \multicolumn{2}{c}{ Residencias } \\
\hline $\mathrm{f}_{0}(\mathrm{~mm} / \mathrm{h})$ & 67.8 & $(18.8-123.3)$ & 88.7 & $(36.4-208.6)$ & 68.8 & $(35.6-94.6)$ \\
$\mathrm{f}_{\mathrm{b}}(\mathrm{mm} / \mathrm{h})$ & 22.7 & $(12.5-36.6)$ & 30.4 & $(14.7-47.8)$ & 23.3 & $(13.3-35.5)$ \\
$\mathrm{k}(1 / \mathrm{h})$ & 9.9 & $(3.9-16.2)$ & 15.5 & $(4.0-51.1)$ & 7.7 & $(1.6-19.2)$ \\
\hline
\end{tabular}

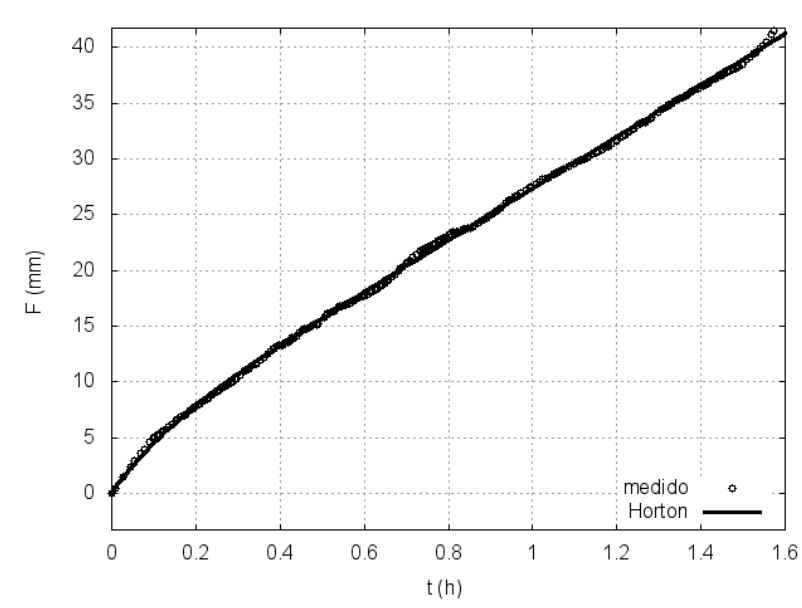

Figura 3. Infiltración acumulada medida $\mathrm{y}$ simulada por Horton - $2^{\circ}$ medición - casa $\mathrm{B}^{\mathrm{o}}$ Marqués de Sobremonte.

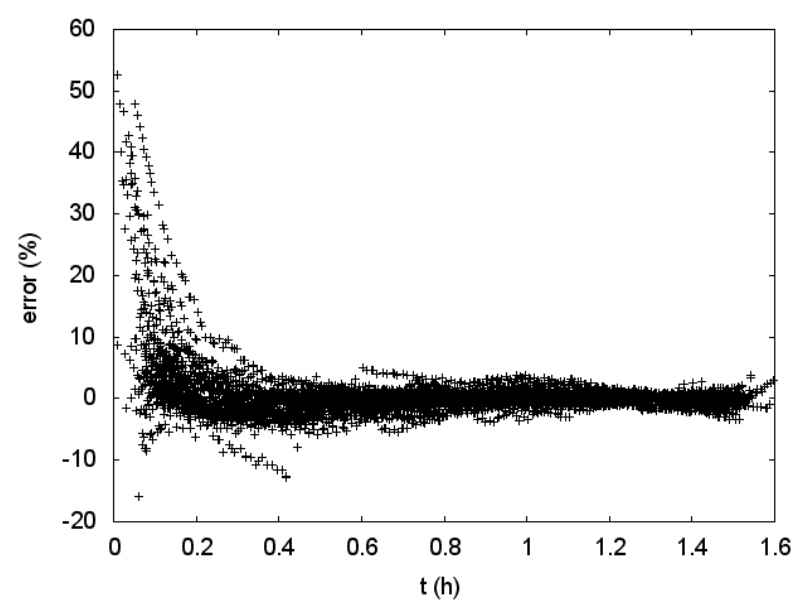

Figura 5. Error (en \%) en la estimación de la infiltración acumulada en función del tiempo de ensayo.

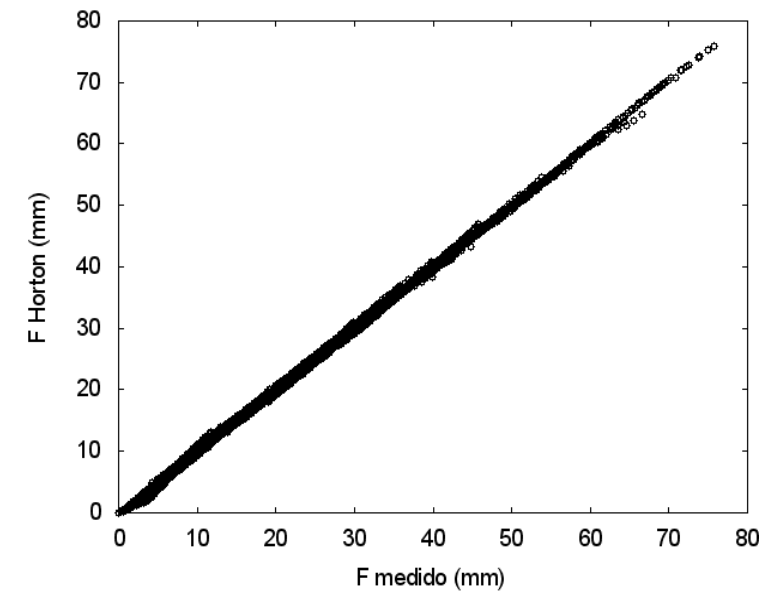

Figura 4. Infiltración acumulada medida versus simulada por Horton.

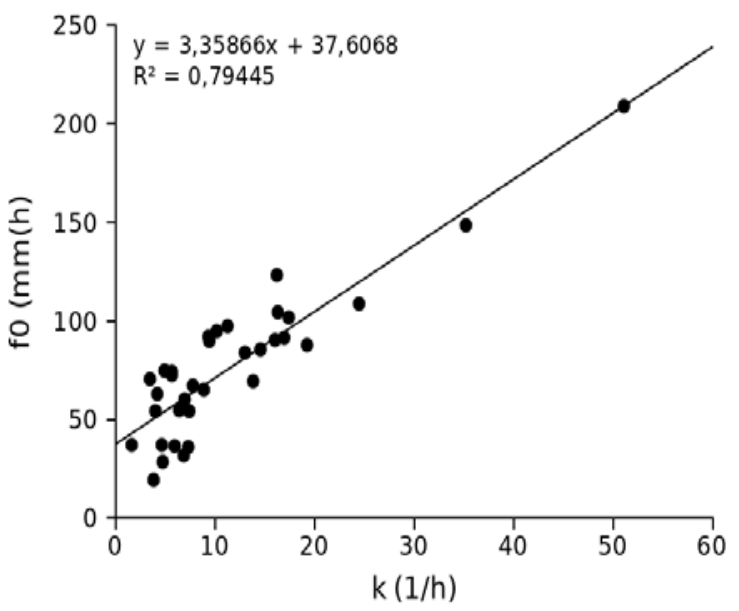

Figura 6. Relación entre parámetros $f_{0} \mathrm{y} k$. 


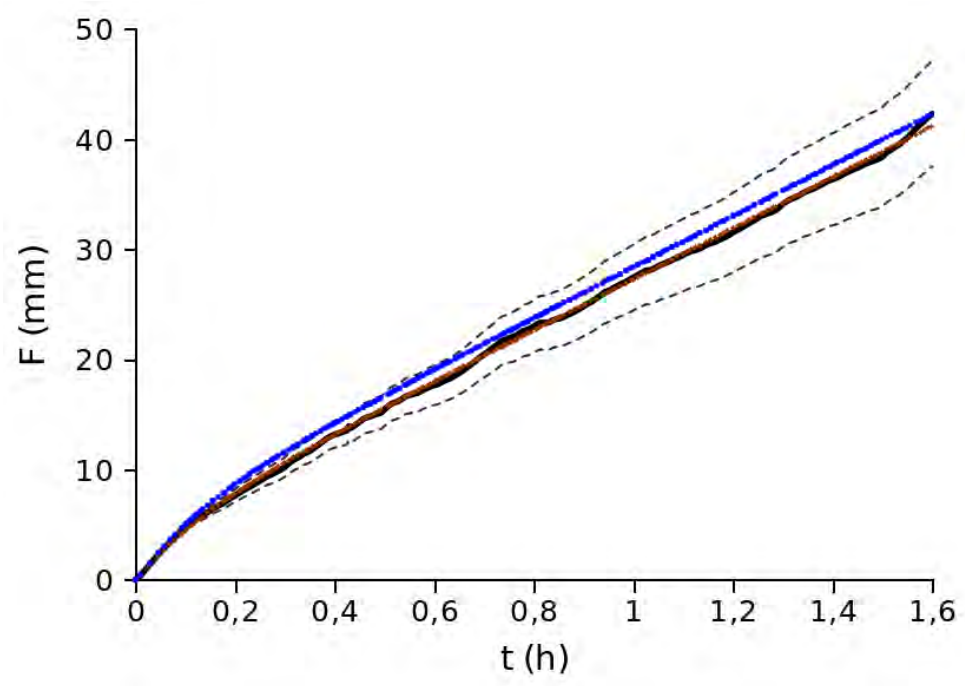

Figura 7. Infiltración medida (línea negra), su banda de incertidumbre (línea de trazo), valores predichos por Horton a 3 parámetros (puntos rojos) o con la Ecuación 6 (puntos azules).

\section{CONCLUSIONES}

A partir de la información recopilada in situ durante la campaña realizada en diversos sitios de la ciudad de Córdoba, ha sido posible ajustar los parámetros del modelo de infiltración de Horton. En promedio, los sitios correspondientes a parques y paseos públicos presentaron los mayores valores en los tres parámetros del modelo, frente a los jardines residenciales y las calles de tierra. Los mayores errores porcentuales en la estimación de la infiltración ocurren para valores bajos de la misma, por tanto al comienzo del proceso. Ha sido posible detectar una cierta dependencia entre los parámetros $f_{0}$ y $k$, cuyo ajuste por regresión lineal da lugar a una expresión que permitiría reducir a dos el número de parámetros libres del modelo, con cierto sacrificio en la calidad de los resultados. A pesar de ello, estos errores son compatibles con los de la propia lluvia generada, y por tanto, con los de la infiltración medida, lo que permitiría utilizar la Ecuación 6 como un estimador del valor de $f_{0}$ a partir de $k$ (o viceversa).

En cualquier caso, se considera que el conjunto de parámetros así ajustados resultará de interés para los proyectistas vinculados al manejo del escurrimiento pluvial urbano en la ciudad.

\section{REFERENCIAS}

ACHUTEGUI, A.; ABREU X.; PÁEZ M. L. Diseño y evaluación de un simulador de lluvias tipo gotero con efecto vibratorio. Venesuelos, v. 4, p. 24-28, 1996.

AOKI A. M.; SERENO R. Modificaciones de un microsimulador de lluvia. Investigación Agrícola, v. 19, n. 1/2, p. 47-51, 1999.

BENITO, E.; SANTIAGO, J. L.; DE BLAS, E.; VARELA, M. E. Deforestation of waterrepellent soils in Galicia (NW Spain): effects on surface runoff and erosion under simulated rainfall. Earth Surface Processes and Landforms, v. 28, p. 145-155, 2003. http://dx.doi.org/10.1002/esp.431 
CHOW, V. T.; MAIDMENT, D. R.; MAYS, L. W. Hidrología aplicada. Santafé de Bogotá: McGraw-Hill Interamericana, 1994.

EATON, J. W.; BATEMAN, D.; HAUBERG, S. GNU Octave: a high-level interactive language for numerical computations. Disponible en: www.octave.org. Acceso en : 2007.

HORTON, R. E. Analysis of runoff-plot experiments with varying infiltration capacity. Transactions American Goephysical Union, Washington, p. 693-711, 1939.

IRURTIA C. B.; MON R. Microsimulador de lluvia para determinar infiltración a campo. Publicación No 176. Buenos Aires: Instituto de Suelos, 1994. p. 18.

KAMPHORST, A. A Small rainfall simulator for the determination of soil erodibility. Netherlands Journal of Agricultural Science, v. 35, p. 407 - 415, 1987.

MATHEWS, J. H.; FINK, K. D. Numerical methods using Matlab, 4th Ed. [S.1.]: Pearson Prentice Hall, 2004.

QUINTANA SALVAT, F.; BARBEITO, O. Base geológica - geomorfológica para la planificación territorial de la ciudad de Córdoba y su entorno - Ejido Municipal. Fotointerpretación, v. 2, n. 1, p. 209-256, 1994.

RAVI, V.; WILLIAMS, J. R. Estimation of infiltration rate in the vadose zone: compilation of simple mathematical models. Volume I. Technical Report No. EPA/600/R-97/128a . Ada: United States Environmental Protection Agency; National Risk Management Research Laboratory, 1998.

TUCCI, C. E. M. Urban drainage in humid tropics. In: MAKSIMOVIC, C. Urban drainage in specific climates. Paris: UNESCO, 2001. Vol. 1. (IHP-V - Technical Documents in Hydrology, 40).

WEBER, J. F.; URBANO, J. M.; STUYCK, E. E.; AZELART, D.; MARTÍNEZ, N. B. Caracterización de los parámetros del modelo de Infiltración de Horton en suelos de la ciudad de Córdoba. Cuadernos del Curiham, v. 11, n. 1, p. 29-38, 2005.

WEBER, J. F.; PAOLI, H. I.; APESTEGUI, L. Microsimulador de lluvia portátil para estudios hidrológicos. Tecnología y Ciencia, año 9, n. 18, p. 47-53, 2010. 


Ambiente \& Água - An Interdisciplinary Journal of Applied Science
ISSN 1980-993X - doi:10.4136/1980-993X
www.ambi-agua.net
E-mail: ambi-agua@agro.unitau.br

\title{
Análisis jurídico sobre la calidad del servicio del agua en Buenos Aires
}

\author{
doi: $10.4136 / a m b i-a g u a .1228$
}

Received: 23 Oct 2013; Accepted: 11 Mar. 2014

\section{Clara María Minaverry}

\author{
Universidad de Buenos Aires, y Consejo Nacional de Investigaciones Científicas y Técnicas (CONICET), \\ Buenos Aires, Argentina \\ Instituto de Investigaciones Jurídicas y Sociales Ambrosio Lucas Gioja, Facultad de Derecho \\ cminaverry@derecho.uba.ar
}

\section{RESUMEN}

El presente trabajo tiene como objetivo general analizar la eficacia de una serie de casos jurisprudenciales y de normativa seleccionada, en relación con la protección de la calidad del servicio de agua potable en la ciudad de Buenos Aires. En primer lugar, se recopiló doctrina, normativa y jurisprudencia nacional, todos vinculados con el estado de situación de la calidad de dicho servicio. Desde el punto de vista metodológico se utilizó el método de observación documental, y los datos cualitativos a recoger fueron secundarios (doctrina, normativa y jurisprudencia). A tal fin se analizaron profundamente tres leading cases, los cuales podrían fijar lineamientos generales para futuros proyectos de leyes y para políticas públicas que fomenten un servicio más sustentable.

Palabras-clave: jurisprudencia, agua, Argentina.

\section{Análise jurídica sobre a qualidade do serviço de água potável em Buenos Aires}

\section{RESUMO}

O presente trabalho teve como objetivo geral analisar a eficácia e alguns casos de jurisprudência e da norma legal selecionada pertinente à qualidade do serviço de água potável na cidade de Buenos Aires. Em primeiro lugar, foi realizado um levantamento da doutrina, leis e jurisprudência nacional, aspectos vinculados à qualidade da água na região avaliada. Do ponto de vista metodológico foi utilizado o método da observação documental por meio de dados qualitativos secundários (doutrina, leis e jurisprudência). Com tal fim, foram analisados profundamente três casos chaves, que podem estabelecer linhas gerais para futuros projetos de leis e políticas públicas para fomentar um serviço mais sustentável.

Palavras-chave: jurisprudência, água, Argentina. 


\title{
Legal analysis about drinking water quality service in Buenos Aires
}

\begin{abstract}
The general purpose of this paper was to analyze the efficacy of selected case law and regulations regarding piped water service quality in Buenos Aires. We searched first for jurisprudence, regulations and case law relating to the quality of water service in Buenos Aires. We used the documentary observation method, and the qualitative data were categorized as secondary (jurisprudence, regulations and case law). We analyzed three leading cases, which might be useful to set general guidelines for future law projects and public policies in order to have a more sustainable service.
\end{abstract}

Keywords: case law, water, Argentina.

\section{INTRODUCCIÓN}

El 60 o el 70\% aproximadamente del cuerpo humano está compuesto por agua, y hoy en día no cabe duda que la misma es limitada y que debe ser especialmente cuidada y valorada (Minaverry, 2013b). La mayor cantidad de agua es salada (el 97,5\%), mientras que el resto corresponde a lagos, ríos, reservorios, recursos subterráneos, humedad del suelo, glaciares y nieves. Por eso, debe prestarse especial atención a la fuente del agua que consumimos todos los días, ya que forma parte de esa minoría que es dulce y que no tiene que ser sometida al proceso de desalinización, que supone altos costos económicos y contaminación del medioambiente.

Otra limitación vinculada con los recursos hídricos se relaciona con la distribución de los mismos en el territorio, con la cantidad y con la ubicación de la población mundial. En Sudamérica la situación es muy favorable, porque el balance existente entre la disponibilidad del agua y el porcentaje de la población es positivo. Actualmente, existen más reservas de agua que cantidad de personas demandando su uso, ya que en esta área habita solamente el $6 \%$ de la población que posee el $26 \%$ de los recursos hídricos mundiales.

Sin embargo, algunos estudios informan que "en Argentina millones de personas se abastecen de agua no apta para el consumo humano ya que el recurso subterráneo está contaminado; que los pozos no tienen adecuada profundidad o carecen de los requisitos técnicos idóneos para evitar la infiltración de contaminantes" (CELS et al., 2009).

En este orden de ideas, se detectó un déficit en los servicios de suministro de agua potable en la mayoría de los países de Latinoamérica, debido a que los niveles de inversión histórica habían estado por debajo de sus necesidades (Lentini, 2011). Esto fue consecuencia de un congelamiento de las tarifas durante muchos años, a pesar de que al comienzo de las privatizaciones se habían registrado varias inversiones en infraestructura si se lo compara con el período de la empresa pública (Alcazar et al., 2000).

Algunos organismos internacionales ya habían detectado ciertos incumplimientos en nuestra región, al afirmar que durante algunos años en diversas ciudades se encontraron niveles excesivos de nitrato en agua de red y por cuatro años consecutivos los estudios revelaron un aumento en la cantidad de pozos con arsénico (Transparency International, 2008).

Para poder alcanzar los niveles básicos de calidad se requiere que el servicio cumpla satisfactoriamente con todas las obligaciones legales existentes, y a su vez que los usuarios brinden una contraprestación razonable del servicio.

"El suministro de agua potable, y en especial los servicios de alcantarillado y tratamiento de aguas servidas, requieren más inversión de capital que otros servicios de utilidad pública: casi veinticinco veces los ingresos anuales" (Solanes, 2008). 
Debe destacarse la importancia que existe en realizar inversiones adecuadas y planificadas para mantener el nivel de la infraestructura requerida para brindar el servicio, y así mantener un alto nivel de calidad del agua (Rouse, 2007).

En este sentido "se ha calculado que alrededor del $65 \%$ de los costos totales para el servicio de agua corresponden al capital, en tanto que la vida útil de los activos es de 20 a 40 años" (Ferro e Lentini, 2012).

Entre éstos aparece la obligación de brindar una adecuada presión que es considerada como la media ponderada en diez metros de columna de agua por inmueble. A su vez, se exige un adecuado sistema de monitoreo.

La continuidad se refiere a que la prestación no puede ser interrumpida y entre otras cosas, se relaciona con la inembargabilidad de los bienes afectados por ser de dominio público, es decir por constituir el conjunto de bienes propiedad del Estado afectados por la ley al uso directo o indirecto de los habitantes (Prado, 1997).

Algunos doctrinarios afirman muy acertadamente que "ciertos estándares no son negociables: la calidad química y bacteriológica del servicio tiene parámetros legales de cumplimiento obligatorio por cuestiones sanitarias y de la preservación de la vida. La reducción de los costos para controlar la calidad implica que en un determinado plazo se pagará esto de manera mucho más cara" (Lentini, 2011).

\section{OBJETIVOS Y JUSTIFICACIÓN}

Objetivo general: Analizar la eficacia de los casos jurisprudenciales y de la normativa seleccionada, en relación con la protección de la calidad del servicio de agua potable en la ciudad de Buenos Aires.

Objetivos específicos:

a) Analizar si la jurisprudencia y la normativa seleccionadas poseen sanciones que sean disuasorias ante casos de incumplimiento normativo en el nivel de calidad del suministro de agua potable en la ciudad de Buenos Aires.

b) Analizar si la jurisprudencia y la normativa seleccionadas poseen un sistema de control de calidad que haya sido ejercido por el Estado en el suministro de agua potable en la ciudad de Buenos Aires.

La importancia del presente trabajo radica en que para el caso de Argentina, la situación de la disponibilidad hídrica superficial (dejando de lado las fuentes subterráneas y de los glaciares), cuenta con una gran variedad de fuentes de recursos hídricos, en especial si lo comparamos con otros países de la región como Chile.

Sin embargo, muchos de los recursos hídricos están siendo contaminados, como consecuencia de escasos o ineficientes controles estatales, falta de educación ambiental y de responsabilidad individual y colectiva, y esto repercute directamente en la calidad del servicio de agua potable (si las empresas y el Estado no intervienen eficientemente).

El ámbito espacial de esta investigación (ciudad de Buenos Aires) se nutre de manera directa del recurso del agua, ya que puede acceder fácilmente al Río de la Plata. Esto le da ventaja en relación a otras zonas del país, como es el caso de algunas áreas del norte y centro.

\section{MATERIALES Y MÉTODOS}

a) Fase exploratoria:

Se recopiló normativa y jurisprudencia nacional vinculadas con el estado de situación de la calidad del servicio del agua potable en Buenos Aires. Además se realizó una selección de 
obras doctrinarias y de aplicación empírica sobre la temática de la calidad del agua. A tal fin se utilizaron los siguientes buscadores jurídicos: Microjuris, Ecolex y Lexpro, y luego se fueron detectando los aspectos fundamentales de la doctrina, normativa y de los casos jurisprudenciales.

b) Fase descriptiva:

1- La información recogida en la etapa anterior fue clasificada y categorizada (utilizando los criterios de división territorial, jurisdiccional y doctrinario), a fin de facilitar su análisis en una etapa posterior.

2- Se realizó una descripción de "casos" en los que el núcleo duro de la cuestión fue la calidad del agua. De ello obtuvimos información relevante para arribar a algunas conclusiones generales.

c) Fase analítica:

1- El análisis de los documentos vinculantes y no vinculantes recogidos en la fase exploratoria tuvo por objeto detectar los principios y marcos legales que, debido a su reiteración constante y uniforme, fueron tomados en cuenta para enriquecer el marco teórico de esta investigación.

2- Se categorizaron los estudios de caso publicados en revistas o por organismos nacionales e internacionales de reconocida trayectoria.

Desde el punto de vista metodológico, se utilizó el método de observación documental, el cual consiste en obtener información mediante la percepción selectiva, ilustrada e interpretativa de un fenómeno determinado. Dentro de las posibles modalidades se implementó la "observación directa", ya que los datos se recogieron directamente de los fenómenos percibidos mediante registros sistematizados con la recolección.

Asimismo se utilizaron los métodos analítico y comparativo de datos, siendo que se comparó legislación y jurisprudencia de distintas jurisdicciones de Argentina.

Los datos cualitativos recogidos fueron secundarios (análisis de registros escritos, tales como doctrina, jurisprudencia, y legislación).

\section{RESULTADOS Y DISCUSIÓN}

\section{1. Estado de situación del control de calidad del servicio de agua en Buenos Aires}

La actual empresa concesionaria que provee el servicio en Buenos Aires desde 2006 (Agua y Saneamientos Argentinos S.A) posee dos clases de controles de la calidad del agua:

a) Directos: Cuando los inspectores se dirigen a la industria y donde la Administración Pública es responsable directa del control.

b) Indirectos: Se mide a través de indicadores de cuencas. Su función principal es la de monitorear el manejo de los planes y acciones destinados a la gestión de una cuenca hídrica (Arg Cap-Net, 2013).

Ambos se definen conforme a lo establecido en la ley nacional 26.221 (Argentina, 2007) (Anexo A), donde se describen los niveles de calidad del agua exigidos para el consumo.

Se han intensificado los controles ambientales a partir de la firma de un convenio con la Autoridad de la Cuenca Matanza Riachuelo (ACUMAR), tal es el caso del control de cianuros. En caso de detectarse esta sustancia en el agua se ordena de inmediato el corte de las actividades de las industrias de la zona.

Además la empresa implementó lo siguiente:

a) Aplicación de estrictos controles durante las 24 horas, los 365 días del año.

b) Los controles de calidad que se realizan al agua abarcan todas las etapas del proceso. 
c) Las normas de calidad del agua que debe cumplir la empresa incluyen 58 parámetros definidos por el Marco Regulatorio, los cuales se basan en las exigencias del Código Alimentario Argentino, y de las principales guías y normas internacionales de referencia en la temática (Organización Mundial de la Salud (OMS).

d) El Laboratorio Central se encuentra equipado con tecnología de punta e instrumental de última generación, y con personal altamente capacitado (AYSA, 2013).

Las muestras de agua se toman en más de cuatrocientos puntos fijos de las redes distribuidoras, y se focaliza en los siguientes parámetros (turbiedad, análisis bacteriológicos, determinaciones biológicas, parásitos y otros patógenos), establecidos en la normativa que se analizará más adelante (AYSA, 2013). Se ha comenzado a trabajar interdisciplinariamente y conjuntamente entre la empresa, el Instituto Nacional del Agua (INA) y Redes de Laboratorio.

\subsection{Análisis sobre la normativa vinculada con la calidad del servicio del agua}

A continuación se describirá la normativa sobre calidad del agua, que es aplicable a los municipios de la Provincia de Buenos Aires. Las mismas han sido divididas en dos áreas:

a) Normas correspondientes al período concesionado a empresas privadas3:

Decreto Provincial 878/2003, capítulo V (Buenos Aires, 1996).

b) Normas correspondientes al período de provisión estatal del servicio:

Ley 26.221 de 2007, Anexo A y capítulo II punto 6.

De acuerdo a la normativa anterior, puede afirmarse que existe un solapamiento legal entre la ley nacional 26.221 de 2007 y el decreto provincial 878/2003, ya que ambos están vigentes para el ámbito de la Provincia de Buenos Aires.

En el artículo 8 inciso j) del decreto 878/2003 se incluyeron las definiciones aplicables a la norma, y allí se estableció que dicha Comisión será la autoridad que determinará las características que debe tener el agua para ser considerada potable.

La categoría de agua corriente que está prevista para consumo humano, no cuenta con ningún parámetro legal de calidad exigible a las empresas que proveen la misma.

Además, este decreto resulta paradigmático, ya que ha creado dos categorías de agua que están permitidas para el consumo humano pero que poseen características diferentes:

a) "Agua Potable: Agua que cumple con todos y cada uno de los límites impuestos por la Comisión Permanente de Normas de Potabilidad y Calidad de Vertido de Efluentes Líquidos y Subproductos.

b) Agua Corriente para el consumo humano e higiene: Agua que no cumple con algunos de los límites impuestos por la Comisión Permanente de Normas de Potabilidad y Calidad de Vertido de Efluentes Líquidos y Subproductos, pero cuya ingesta puede ser autorizada por períodos limitados"

En el inciso b) el término "algunos" aplicado a los límites de calidad del agua no ha sido definido y por lo tanto existe una laguna jurídica.

Además se establece que el agua corriente puede ser consumida por "períodos limitados", que tampoco se han definido y que pone en peligro la salud de los usuarios (cuya responsabilidad corresponde a la Administración Pública).

Luego, el instrumento de vinculación firmado entre Aysa S.A. y el Estado Nacional solicita que se cumpla con el marco regulatorio y con las normas que se vinculan con la calidad del agua potable (pero no explican a cuáles se refieren pudiendo detectarse una laguna jurídica). 


\subsection{Casos jurisprudenciales vinculados con el nivel de cumplimiento legal de la calidad del servicio del agua}

\subsubsection{El caso "Municipalidad de Berazategui contra Aguas Argentinas S.A. sobre ordinario"}

En este caso que tramitó ante la Cámara Federal de Apelaciones de La Plata en 2003, y se cuestionó la falta de inversión en el tratamiento de efluentes cloacales en áreas de tomas de agua potable, y el incumplimiento en el monitoreo de la calidad del agua.

Sin duda que aquí el bien jurídico protegido es el agua potable, ya que su objetivo es que sea de óptima calidad de acuerdo a los parámetros de salud abalados internacionalmente.

Desde el punto de vista procesal, se llegó a una instancia de apelación porque el juez de grado no hizo lugar a la medida cautelar solicitada por la parte actora, alegando que no se encontraban cumplidos y acreditados los requisitos exigidos por la ley tales como la verosimilitud en el derecho y el peligro en la demora.

En la misma se demandó a la empresa prestataria del servicio de agua (Aguas Argentinas S.A.), solicitando que se la condene para que cese de inmediato con la contaminación de las aguas del Río de la Plata, repare los daños ambientales e indemnice los daños civiles causados.

La actora amplió su pretensión contra el Estado Nacional, para que ordene la ejecución de un plan para la construcción de una planta de tratamiento de los efluentes cloacales que se vertían en las aguas del Río de la Plata.

En este caso no se mencionaron los principios de precaución ni de prevención, porque el daño ya se había producido, lo cual se justificó en el apartado 12 del fallo:

"Esta situación, además, pone en riesgo de contaminación a las tomas de agua potable situadas sobre la costa del Río de la Plata bajo condiciones meteorológicas desfavorables, como así también produce la degradación de la línea de costa en el entorno de vertido."

A esto hay que sumarle la situación denunciada por el Ente Regulador del Agua (ETOSS) por haberse detectado descargas de mercurio en el Río de la Plata (considerando 13).

Uno de los principios ambientales que se encuentran mencionados en la sentencia es el de "contaminador - pagador", que implica que los responsables de la contaminación o degradación deben soportar gastos necesarios para prevenir o corregir el deterioro ambiental, tratándose los "costos sociales" que antes no se incluían en estos cálculos.

Las fuentes del derecho que se han incorporado en este caso pertenecen al ámbito nacional y al internacional.

Resulta novedoso que se haya citado el caso "Municipalidad de Magdalena contra Shell CAPSA y otros sobre disposición de residuos peligrosos" de 2003, afirmando que la acción contaminante resulta ilícita por contrariar a las normas de la Constitución, a los tratados internacionales y a las leyes nacionales y genera prioritariamente la obligación de recomponer el medio ambiente.

Se ha reconocido expresamente que la demandada no ha cumplido legalmente con ciertos aspectos claves vinculados con los niveles de inversión de infraestructura:

"Aguas Argentinas no realizó las nuevas obras ni adelantó inversiones y, a menos de dos años del contrato, formuló una propuesta de renegociación [...] al tercer año de la concesión las inversiones no realizadas ya pasaban de los 300 millones y en los dos años siguientes el incumplimiento se agravó, acercándose al cumplirse el primer quinquenio a la mitad de lo comprometido."

La parte demandada sostuvo que se había cumplido con las normas de calidad vigentes, y que en el mismo no se exigió la implementación de inversiones como es el aumento de la 
capacidad de producción y la potabilización del agua, sobre todo en relación con la expansión del servicio de agua y en el sistema de saneamiento.

Podemos destacar que las lagunas normativas existentes en esta área, representan un aspecto fundamental que debería ser tenido en cuenta en un futuro inmediato.

Este caso también ha servido para subsanar lo anterior, ya que se estableció que a pesar de que la empresa ha cumplido con dicha exigencia normativa, esto no resulta suficiente como para eximir de responsabilidad a la misma.

Una de las temáticas del fallo, es que la actora acertadamente sostuvo lo siguiente:

"Se advierte una clara responsabilidad del Estado en el ejercicio, paradójicamente, de su poder reglamentario, tanto en su legítima acción como por sus injustificadas omisiones en el marco de la renegociación del contrato de concesión."

Al tratarse de un servicio público básico para la vida, se consideró como responsable al Estado (en todos los casos), dándole un lugar destacado en relación con la empresa.

Otro de los aspectos que cuestionó la parte demandada es que había solicitado una renegociación de su contrato, alegando lo siguiente:

"Los documentos con los que la propia empresa propuso la renegociación planteaban que la regulación exigió con demasiada rigidez el cumplimiento de un plan cuyas metas eran demasiado "ambiciosas" obedeciendo a las necesidades licitatorias".

Esta problemática también podría haber sido evitada si hubiese existido normativa con exigencias más estrictas, respecto del nivel de compromiso legal de las empresas que suministran el servicio del agua. Por tal insuficiencia, se produjo en varias ocasiones renegociaciones de las condiciones del contrato de concesión por parte de la empresa, lo cual se encuentra dentro del ámbito de legalidad (pacta sunt servanda).

La sentencia del tribunal de segunda instancia fue favorable a la actora al reconocerse la falta de inversión en infraestructura y en sistemas de control de calidad.

En la misma se ordenó a la empresa de agua que adopte las medidas necesarias para que en el transcurso de los próximos 18 meses, realice las obras tendientes a la construcción y puesta en marcha de la Planta Depuradora de líquidos cloacales ubicada en Berazategui, como la limpieza y prolongación del emisario cloacal existente en dicha localidad.

Ambos debían presentar mensualmente ante el Tribunal un informe sobre el avance de las obras, por lo que se ha contemplado una instancia posterior de seguimiento que resulta ser muy favorable. Se ha determinado una responsabilidad concurrente de la empresa de aguas y del Estado Nacional, lo cual resulta innovador ya que la mayoría de los casos jurisprudenciales analizados sobre esta temática reconocen alguna clase de responsabilidad con mayor implicancia hacia alguno de los demandados.

\subsubsection{El caso "Biondo Esteban contra Secretaría de Recursos Naturales y Ambiente Humano - Poder Ejecutivo Nacional sobre amparo"}

Un Concejal del Partido de Berazategui (Provincia de Buenos Aires, Argentina) promovió una acción de amparo contra la ex Secretaría de Recurso Naturales y Ambiente Humano (actual Secretaría de Ambiente y Desarrollo Sustentable de la Nación) en 1999, fundamentado en la afectación de sus derechos constitucionales de vivir en un ambiente sano y equilibrado y a la salud (artículos 41,43 y 31 de la Constitución Nacional), y también por la grave contaminación que sufría el Río de la Plata.

En su recurso alegó que el mismo era una fuente de abastecimiento de agua potable, y al mismo tiempo cuerpo receptor de desagües cloacales e industriales sin tratamiento previo, provocando que el Río de la Plata vea agotada su capacidad de autodepuración.

Los demandados fueron responsabilizados por haber incumplido su deber de poder de policía, en tanto que debieron ejercer el control de la contaminación hídrica, y afirmaron que su obligación subsistía más allá de las funciones de fiscalización de organismos como el 
ETOSS (ya que éste se limitó al cumplimiento del contrato de concesión de Aguas Argentinas S.A). Aquí se reconocieron las limitaciones estructurales y de funcionamiento que registran estos organismos de control.

A los fines de proteger la calidad del agua potable, el actor solicitó que la ex Secretaría de Recursos Naturales y Ambiente Humano defina lo siguiente:

- "Un programa de control efectivo de los desechos industriales que llegaran directa o indirectamente al Río de la Plata (en especial los generados por las industrias).

- Un sistema de monitoreo permanente de la calidad de dichos efluentes.

- La reubicación de las tomas de agua del concesionario en el Río de la Plata para su potabilización.

- El cumplimiento de los plazos para la construcción de una planta de tratamiento de desechos cloacales e industriales de las tres colectoras máximas que tienen su desaguadero en Berazategui."

La sentencia de primera instancia rechazó la demanda de la actora basándose en cuestiones de forma pero no de fondo, a pesar de encontrarse en juego derechos constitucionales (principalmente los artículos 41, 43 y 31 ).

El juez consideró que no se había cumplido con los requisitos de admisibilidad de la acción de amparo, porque existían otros remedios legales para resolver la cuestión (pero nunca se especificaron cuáles eran).

La demandada ya había presentado el informe solicitado en el artículo 8 de la ley nacional 16.986 de acción de amparo de 1966, alegando que se encontraban ante la ausencia de un caso judicial y de un acto administrativo concreto que afecte los derechos constitucionales cuestionados.

Además sostuvo que se requería mayor amplitud probatoria, ya que se estaban sometiendo a revisión cuestiones propias del poder administrador, por lo que este procedimiento no era considerado como el más idóneo para la resolución de una problemática con complejidad jurídica.

La Cámara de Apelaciones revocó la sentencia de primera instancia y atendió parcialmente las peticiones de la actora, y resolvió requerir informes de los últimos cinco años a todos los demandados en un plazo de noventa días, basándose en la ley general del ambiente 25.675 de 2002 que otorga dicha potestad.

A su vez, exigió el cumplimiento del derecho de acceso a la información (principio fundamental del Derecho Ambiental), y de disponer de todas las medidas necesarias para ordenar o probar hechos que generan un daño a intereses colectivos (en este caso el ambiente).

El fallo de segunda instancia judicial ha sido contrario a lo resuelto en la primera, pero ha mantenido un adecuado criterio lógico.

En este caso se pudo vislumbrar también que en el informe del ETOSS se había aprobado un plan de saneamiento integral, que estaba incorporado en el contrato de concesión pero que estaba sujeto a su aprobación definitiva. Cabe destacar que en el ámbito del Derecho Ambiental la dilación del tiempo genera un mayor daño al medioambiente, y que en muchos casos el mismo puede ser irreversible.

\subsubsection{El caso "Conde, Alberto José Luis y otro contra Aguas Bonaerenses S.A. sobre amparo"}

Un grupo de ciudadanos de la localidad de Lincoln, Provincia de Buenos Aires, interpuso una demanda contra dicha empresa por recibir en sus hogares agua con un valor de arsénico que excedía lo recomendado por la Organización Mundial de la Salud.

La Corte Suprema de Justicia de la Provincia de Buenos Aires exigió a la empresa "Aguas Bonaerenses Sociedad Anónima (ABSA)", suministrar a los usuarios agua potable 
con niveles de arsénico inferiores a 0,01 miligramos por litro en el mes de noviembre de 2013. Debe destacarse que ese es el nivel impuesto en el Código Alimentario Nacional.

Esto ocurrió a partir de la reforma del año 2007, que reflejó los "valores guías" establecidos por la Organización Mundial de la Salud en el año 2004. Previamente, el nivel de tolerancia era más alto: permitía hasta 0,05 miligramos por litro. Sin embargo, el artículo 982 dispone que "Para aquellas regiones del país con suelos de alto contenido de arsénico, se establece un plazo de hasta 5 años para adecuarse al valor de $0,01 \mathrm{mg} / \mathrm{l}$ ”. Ese plazo de cinco años venció en 2012 pero fue prorrogado en febrero del mismo año.

Sin embargo, la empresa de agua estableció su imposibilidad práctica de cumplir con este fallo judicial de inmediato, debido a la magnitud de la inversión que demandan las obras para remover el arsénico del agua.

\section{CONCLUSIONES}

A lo largo del trabajo se ha podido lograr el objetivo general que consistía en analizar la eficacia de los casos jurisprudenciales y de la normativa seleccionada, en relación con la protección de la calidad del servicio de agua potable en la ciudad de Buenos Aires. Se ha podido determinar que esta eficacia es parcial, ya que ninguno de las dos fuentes del Derecho analizadas brinda herramientas ni soluciones absolutas para resolver la problemática de la protección de la calidad del servicio de agua potable.

Luego respecto de los objetivos específicos, del análisis jurisprudencial surge que en los mismos las sanciones son más exigentes que en otros casos ambientales que se han resuelto a nivel nacional (Buenos Aires, 2008). A su vez, cuando se imponen sanciones, en la mayoría de los casos los estándares ambientales y los montos de las multas se encuentran desactualizados.

En los fallos judiciales seleccionados se le exigió al demandado una "obligación de hacer", que resulta fundamental para asegurar el acceso a un servicio de agua de buena calidad, mientras que el nivel de control por parte de los organismos responsables fue evaluado como deficiente por parte de los tribunales correspondientes.

También se exigió un plan de monitoreo (muy exhaustivo), que implica una obligación adicional a los requerimientos solicitados al Estado (actuando de forma adecuada en relación al control público).

En síntesis, en dicha jurisprudencia se establecieron sanciones que pueden resultar disuasorias de incumplimiento normativo en el nivel de calidad del suministro de agua potable en la ciudad de Buenos Aires, y la existencia de un sistema de control de calidad que fue ejercido por el Estado en el suministro de agua potable en la ciudad de Buenos Aires.

Sin embargo, en algunos casos jurisprudenciales hemos detectado una escasa voluntad de trabajo conjunto e interdisciplinario en red entre los diferentes poderes y organismos públicos (Capaldo, 2011).

Luego, también respecto de los objetivos específicos, del análisis normativo surgió que las consecuencias jurídicas que surgen de la clasificación del agua para la Provincia de Buenos Aires, es que ambas pueden ser consumidas por seres humanos, a pesar de que poseen distintos estándares de calidad. Esto implica que en la Provincia de Buenos Aires las exigencias para las empresas que proveen el servicio de agua son inferiores a las de otras jurisdicciones (como es el caso de Buenos Aires que surge del punto 4.2).

Esto también indica que los controles públicos son más leves, y lo mismo ocurrirá con el nivel de sanciones por incumplimiento $u$ omisiones normativas.

Sin embargo, el caso de los Partidos de la Provincia de Buenos Aires que actualmente se encuentran incluidos dentro de la concesión de la empresa Aysa S.A., resulta paradigmático ya que es el único ámbito del país donde coexisten simultáneamente la jurisdicción nacional, 
provincial y municipal. Esto genera que se superpongan normativas, y que dos o más organismos sean competentes para aplicar diferentes regulaciones y para controlar la calidad del servicio.

En la norma tampoco se explica qué parámetros de calidad no se estarían cumpliendo, evitándose así saber si esto resulta o no riesgoso para la salud humana.

En síntesis, en dicha normativa no se establecieron sanciones que sean disuasorias de incumplimientos normativos en el nivel de calidad del suministro de agua potable en la ciudad de Buenos Aires, ni un sistema de control de calidad que haya sido ejercido por el Estado en el suministro de agua potable en la ciudad de Buenos Aires.

\section{REFERENCIAS}

ALCAZAR, L.; ABDALA, M.; SHIRLEY, M. The Buenos Aires water concession, The World Bank Development Research Group, Regulation and Competition Policy, p. 21-22, 2000.

AGUA Y SANEANIMENTOS ARGENTINOS S. A. - AYSA. Web site. Disponible en: http://www.aysa.com.ar. Acceso en: 20 julio 2013.

ARGENTINA. Cámara Federal de Apelaciones de La Plata. Municipalidad de Berazategui contra Aguas Argentinas S.A. sobre ordinario. [S.1.]: [s.n.], 2003.

ARGENTINA. Cámara Federal de Apelaciones de La Plata. Biondo Esteban contra Secretaría de Recursos Naturales y Ambiente Humano - Poder Ejecutivo Nacional sobre amparo. [S.1.]: [s.n.], 1999.

ARGENTINA. Ley 26.221, promulgada en 28 febrero de 2007. Disponible en: http://infoleg.mecon.gov.ar/infolegInternet/anexos/125000-129999/125875/norma.htm.

Acceso en: 11 marzo 2014.

BUENOS AIRES (Provincia). Ley 11820, promulgada en 17 julio 1996. Disponible en: http://www.gob.gba.gov.ar/legislacion/legislacion/l-11820.html. Acceso en: 11 marzo 2014.

BUENOS AIRES (Provincia). Cámara de Apelación en lo Contencioso Administrativo de San Martín. Fundación Ecosur Ecológica Cultural y Educ. desde los pueblos del Sur contra Municipalidad de Vicente López y otro sobre amparo. [S.1.]: [s.n], 2008.

BUENOS AIRES (Provincia). Suprema Corte de Justicia de la Provincia de Buenos Aires. Conde, Alberto José Luis y otro contra Aguas Bonaerenses S.A. sobre amparo. [S.1.]:[s.n.], 2013.

CAPALDO, G. Gobernabilidad ambiental y eficacia del Derecho: dos magnitudes del desarrollo sustentable. In: CAPALDO, G. (Ed.). Gobernanza y manejo sustentable del agua. 1. ed. Buenos Aires: Mnemosyne, 2011. p. 39. (Sinergias Ambientales).

CENTRO DE ESTUDIOS LEGALES Y SOCIALES (CELS); ASOCIACIÓN CIVIL POR LA IGUALDAD Y LA JUSTICIA (ACIJ); CENTER ON HOUSING AND RIGHTS AND EVICTION (COHRE). El acceso a agua segura en el área metropolitana de Buenos Aires. Una obligación impostergable: programa servicios públicos. Buenos Aires, 2009. p. 14.

FERRO, G.; LENTINI, E. Infraestructura y equidad social: experiencias en agua potable, saneamiento y transporte urbano de pasajeros en América Latina. Santiago de Chile: División de Recursos Naturales e Infraestructura, 2012. p. 13. 
LENTINI, E. Servicios de agua potable y saneamiento: lecciones de experiencias relevantes Santiago de Chile: CEPAL, 2011.p. 39.

MINAVERRY, C. Análisis sobre el cumplimiento legal de las inversiones en el servicio público del agua en Buenos Aires, Argentina. Actualidad Jurídica Ambiental, v. 6, p. 1-15, 2013a.

MINAVERRY, C. El Derecho como herramienta para la erradicación de escenarios propicios para la corrupción en el servicio de agua. Tesis (Doctoral) - Facultad de Derecho, Universidad de Buenos Aires, Argentina, 2013b.

PRADO, J. Manual de instituciones de derecho público. Buenos Aires: Abeledo Perrot, 1997. p. 260.

RED ARGENTINA DE CAPACITACIÓN Y FORTALECIMIENTO EN GESTIÓN INTEGRADA DE LOS RECURSOS HÍDRICOS (Arg Cap-Net). Web site. Acceso: 25 mayo, 2013.

ROUSE, M. Institutional governance and regulation of water services. Londres: IWA, 2007. p. 39.

SOLANES, M. Descentralización de servicios de agua, eficiencia y acuerdos de protección a la inversión internacional. In: CONFERENCIA INTERNACIONAL SOBRE GESTIÓN DEL AGUA EN PAÍSES FEDERALES Y SEMEJANTES A LOS FEDERALES, 1., 2008, Zaragoza. Memorias... [S.1.: [s.n.], 2008. p. 491-517.

TRANSPARENCY INTERNATIONAL. Informe global de la corrupción 2008: corrupción en el sector del agua. Berlín, 2008. p. 22-40. 